UNIVERSIDADE DE SÃO PAULO

ESCOLA DE COMUNICAÇÕES E ARTES

HENRIQUE IWAO JARDIM DA SILVEIRA

\title{
Colagem musical na música eletrônica experimental
}





\section{Colagem musical na música eletrônica experimental}

Dissertação apresentada ao Programa de Pós-Graduação em Música, da Escola de Comunicações e Artes, da Universidade de São Paulo, para obtenção do título de Mestre em Música.

Área de concentração: Musicologia. Linha de Pesquisa: História, Estilo e Recepção.

Orientador: Prof. Dr. Fernando Henrique de Oliveira lazzetta.

São Paulo 
Autorizo a reprodução e divulgação total ou parcial deste trabalho, por qualquer meio convencional ou eletrônico, para fins de estudo e pesquisa desde que citada a fonte.

\section{Catalogação na publicação Serviço de Biblioteca e Documentação Escola de Comunicações e Artes da Universidade de São Paulo}

Silveira, Henrique Iwao Jardim da

Colagem musical na música eletrônica experimental / Henrique Iwao Jardim da Silveira - São Paulo : H. I. J. Silveira, 2012. $202 \mathrm{p}$.

Dissertação (Mestrado) - Escola de Comunicações e Artes / Universidade de São Paulo.

Orientador: Fernando Henrique de Oliveira lazzetta

1. Colagem musical 2. Música eletrônica experimental 3. Eletroacústica 4. Plunderphonics 5. Referencialidade 6. Citação 7. Sonologia I.lazzetta, Fernando Henrique de Oliveira II. Título 


\section{Folha de aprovação}

Nome: Silveira, Henrique Iwao Jardim da.

Título: Colagem musical na música eletrônica experimental.

Dissertação apresentada ao Programa de Pós-Graduação em Música, da Escola de Comunicações e Artes, da Universidade de São Paulo, para obtenção do título de Mestre em Música.

Aprovado em:

Banca Examinadora

Prof. Dr. Instituição:

Julgamento: Assinatura:

Prof. Dr. Instituição:

Julgamento: Assinatura:

Prof. Dr. Instituição: Julgamento: Assinatura: 



\section{Dedicatória}

1. A todos interessados.

2. Tradução nossa? Minha, você diz. (Tua). 



\section{Agradecimentos}

Àquelas que me deram cadernetas e caderninhos, Carolina Sudati, Naoko Yanagizawa, Sofia Betancor; a CAPES; aos cachorros: Café, Lucky Luke; ao café; ao chá; aos consultados: Bob Ostertag, Eduardo Socha, Erik Bünger, Giuliano Obici, João Paulo Nascimento, Leticia Maria Gil, Luana Bocchino, Marcelo Magalhães, Rodolfo Caesar, Thomas Bey William Bailey, Tiago de Mello, Victor Valentim; aos deuses; aos entrevistados: Alexandre Fenerich, Camilo "Plâncton" Caropreso, Erik Carlson, Guilherme Rebecchi, Jean-Pierre Caron, Johannes Kreidler, Mário Del Nunzio, Paulo "Juju" "Sokobauno" Loureiro; à essência de lavanda; ao Ibrasotope: Natacha Maurer e Aquiles Guimarães, dentre outros; ao MOBILE, projeto financiado pela FAPESP na categoria Projeto Temático, proc. $\mathrm{n}^{\circ}$ 2008/08632-8, e integrantes; ao orientador Fernando lazzetta; aos Silveira: Carlos Takashi, José Maria e Mônica Yumi. 

SILVEIRA, H. I. J. Colagem musical na música eletrônica experimental. 2012. 202 p. Dissertação (Mestrado em Música) - Escola de Comunicações e Artes, Universidade de São Paulo, São Paulo, 2012.

\section{Resumo}

A presente dissertação visa repertoriar e fazer uma reflexão sobre obras e performances de música eletrônica experimental que utilizam músicas e gravações de músicas como material musical. Investiga a colagem musical enquanto prática, em suas diversas possibilidades de emprego. Contextualiza o tema, mostrando antecedentes na tradição da música europeia de concerto e nas artes visuais. Traça uma pequena cronologia a partir do repertório e realiza um histórico quanto às tecnologias empregadas. Introduz categorias importantes, como o sampleamento, o plunderphonics, a citação, o plágio e a intermusicalidade. Aborda o conceito de referencialidade e o coloca como importante fator composicional, relacionando-o a noções como reconhecimento, fontes sonoras e musicais, familiaridade, pastiche. Discorre sobre dois subtemas: o trio bricolagem, assemblagem e descolagem e o período pós-moderno. Conclui pensando a relação entre colagem musical e o caráter de incompletude dos artefatos musicais.

Palavras-chave: colagem musical; música eletrônica experimental; eletroacústica; plunderphonics; referencialidade; citação; sonologia. 

SILVEIRA, H. I. J. Musical collage in electronic experimental music. 2012. 202 p. Dissertação (Mestrado em Música) - Escola de Comunicação e Artes, Universidade de São Paulo, São Paulo, 2012.

\section{Abstract}

This research aims to make a repertoire of and a reflection upon works and performances of electronic experimental music that use music and musical recordings as compositional material. It investigates the practice of musical collage in its several possibilities of use. It starts by contextualizing the theme: showing some antecedents in the european concert music tradition and in the visual arts; making a small chronology from the repertoire and a historical account of the technologies employed. Introduces important categories such as sampling, plunderphonics, quotation, plagiarism and intermusicality. Addresses the concept of referentiality, treating it as an important compositional aspect and relating it with the notions of recognition, sound and musical sources, familiarity, pastiche. Explores two subthemes: the trio bricolage, assemblage, décollage and the postmodern period. In conclusion, thinks about the relation of musical collage and the incompleteness character of musical artefacts.

Key-words: musical collage; electronic experimental music; electroacoustic; plunderphonics; referentiality; quotation; sonology. 



\section{Sumário}

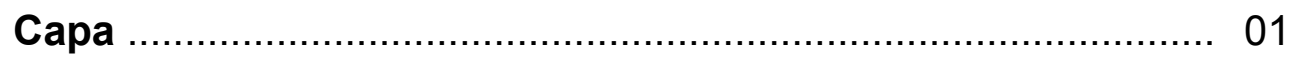

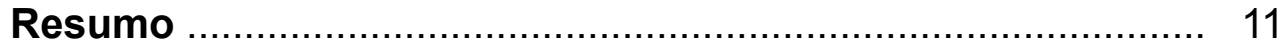

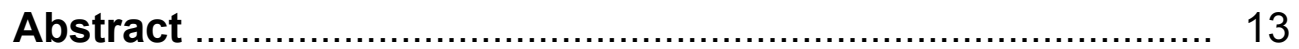

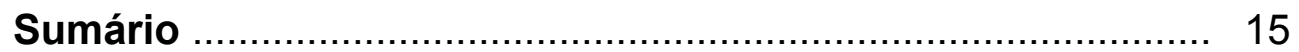

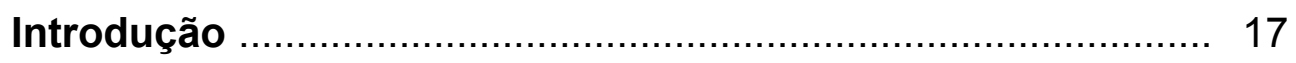

Capítulo 1: Prólogo .......................................................... 23

1.1 Antecedentes na Música de Concerto Europeia .......... 24

1.2 Colagem nas Artes Visuais ....................................... 29

1.3 Pequena Cronologia ................................................... 31

1.4 Tecnologias Empregadas .......................................... 35

Capítulo 2 - Categorias ...................................................... 60

2.1 Música Eletrônica ....................................................... 61

2.2 Música Experimental .............................................. 65

2.3 Música Eletrônica Experimental .................................. 67

2.4 Colagem musical ................................................... 75

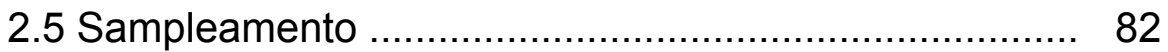

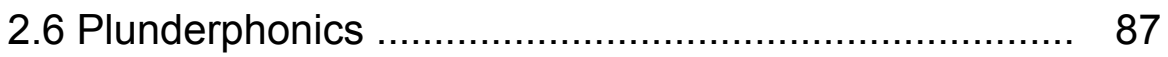

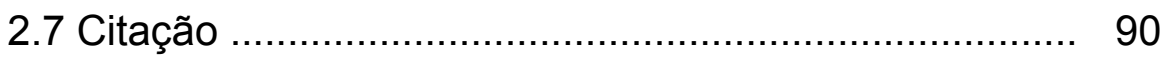

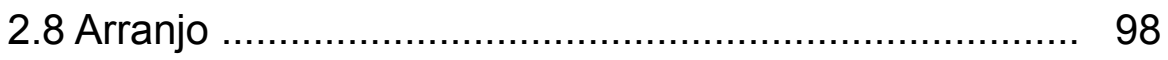

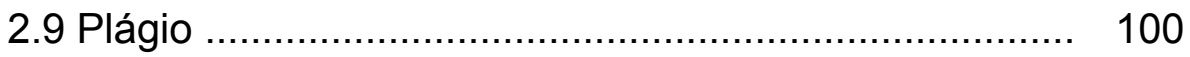

2.10 Intermusicalidade ............................................... 103

Capítulo 3 - Referencialidade ……….................................... 104

3.1 Extra-referencial ....................................................... 104

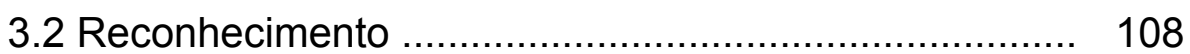

3.3 Fontes ............................................................ 125

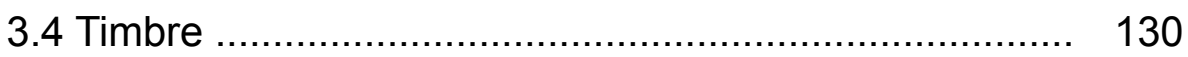

3.5 Familiaridade .................................................. 132

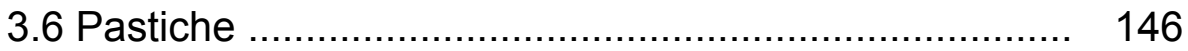

3.7 Temporalidade ................................................. 148 


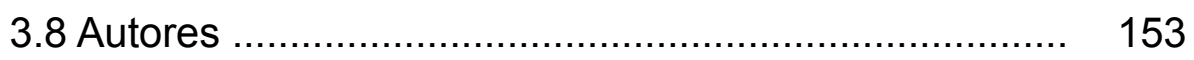

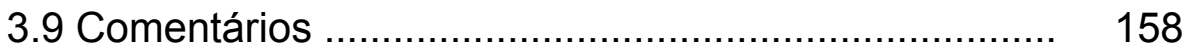

Capítulo 4: Dois Temas .................................................... 161

4.1 Bricolagem, Assemblagem, Descolagem ................... 161

4.2 Período Pós-moderno ................................................ 167

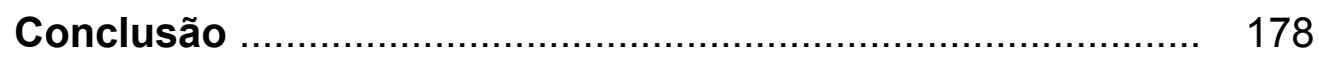

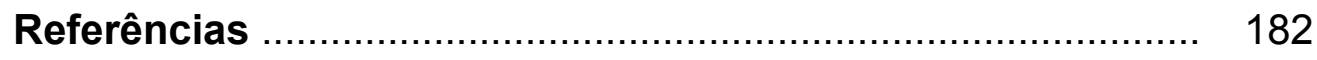

Conteúdo do DVD Anexo …….............................................. 197 
Introdução

Este trabalho traz o tema em seu título: a colagem musical na música eletrônica experimental. Nele examino práticas apropriativas nas quais uma música é utilizada como material composicional para a criação de outro artefato cultural ou para a viabilização de uma ação. Restrinjo a abordagem para o âmbito da música eletrônica experimental, incluindo também exemplos de música eletroacústica. Nesse caso, normalmente gravações de música, isto é, fonogramas musicais, são utilizados como material composicional para a criação de performances e obras musicais. Musical em colagem musical refere-se ao tipo de material que sofre a ação de colagem. O exame das práticas de colagem musical se dá ou em relação às obras e performances repertoriadas, comentando, refletindo ou elencando-as, ou em relação a si próprias, enquanto campo de possibilidades.

Para a pesquisa, construí um repertório de obras que se adéquam ao escopo do tema, bem como o circunscrevi, esboçando seus limites ao apresentar obras que por um motivo ou outro não poderiam ser consideradas pertencentes a ele. As obras que compõem esse repertório são variadas em caráter e procedimentos. Essa diversidade foi abordada estipulando critérios, subtemas e categorias. Tratei também da questão da referencialidade e sua conceituação. Estas ferramentas puderam fornecer subsídios para uma reflexão sobre o repertório. O repertório, por sua vez, pôde exemplificar e contrapor aspectos das ferramentas intelectuais, fornecendo subsídio para uma reflexão sobre estas ferramentas.

Walter Benjamin escreveu a Origem do Drama Trágico Alemão. No ensaio, aborda também obras que não pertencem ao drama trágico alemão. Essas obras criam um contraponto que lhe permite melhor delimitar o tema de sua pesquisa, investigar suas diferenças e singularidades, no que a comparação com o outro torna de esclarecedor quanto de difuso. Ademais, o repertório tratado no livro é vasto e contém obras conhecidas e de grande interesse em si, além de obras obscuras e/ou não muito expressivas. O conteúdo das obras abordadas (dito "objetivo" pelo autor) é encarado como matéria para o pensamento. Em suas palavras: "O objeto da crítica filosófica é o de mostrar que a função da forma artística (...) consiste em transformar em conteúdos de verdade filosóficos os conteúdos históricos objetivos que estão na base de toda a obra de 
arte significativa." (BENJAMIN, 2011, p. 259-60).

Pareceu-me importante seguir os dois procedimentos apontados no ensaio de Benjamin, resguardadas as diferenças entre esse e esta pesquisa. O contraponto com obras não exatamente pertencentes ao escopo fornece diferenças que permitem de fato melhor delimitar as práticas de colagem musical na música eletrônica experimental. A abordagem de exemplos diversos permite mostrar a multiplicidade de tratamentos e enfoques possíveis dentro de um tema. O mergulho dentro da variedade real também permite localizar e teorizar acerca de tendências e características preponderantes. Na teorização, de um modo geral, há um empuxo rumo a um tom de generalidade que acaba por afunilar o objeto de estudo, tornando-o menos difuso, mas a custo de excluir contraexemplos importantes e interessantes. A preocupação em sempre voltar a exemplos específicos contrabalanceia esse empuxo, colocando os pés no chão, quando estes ameaçam alçar voo.

Se há no livro de Benjamin a emergência de uma ideia, uma essência do drama trágico alemão, aqui, por um lado, é dado espaço à tentação de achar algo que emerja como ideia; por outro, essa tentação é tratada com um tom ressabiado e cauteloso. Ademais, como as práticas de colagem musical na música eletrônica experimental não se aglutinam de modo a dar origem a um gênero comum a todas elas, conceitos que poderiam ser vistos como reguladores - e o conceito de referencialidade seria um dos grandes candidatos -, acabam também por deixar inúmeros exemplos e traços significativos do repertório de fora.

A valorização de obras quanto ao potencial fornecimento de material ao pensamento tem uma consequência proveitosa: as ideias e constatações feitas podem ser deslocadas pelo leitor dos exemplos que a geraram, e usadas em outros contextos, tanto musicológicos quanto composicionais.

Em algumas ocasiões propus situações hipotéticas. Abordei dessa forma exemplos possíveis ou futuramente possíveis mas não realizados. Nessas ocasiões me pareceu melhor estabelecer hipóteses e construir argumentos a partir destas, em vez de perder a ocasião de fornecer subsídios ao estudo da colagem musical. Além disso, experimentos mentais são utilizados nas ciências e na filosofia com seriedade e consequências por vezes reveladoras.

Sempre fui fascinado por jogos e argumentos sobre o nomear e os nomes dados. O argumento do Cavaleiro Branco, no livro Through the Looking Glass, de Lewis Carroll, é 
exemplar: há o nome da canção; há como o nome da canção é chamado; há como a canção é chamada; há a canção (referida por outro nome, que corresponderia, esse sim, ao seu ser). Quando o Cavaleiro finalmente se põe a cantar, Alice percebe, no entanto, não se tratar de uma melodia [tune] inventada por ele. Na verdade trata-se de uma melodia com outro nome, apropriada pelo Cavaleiro para sua canção (CARROLL, 1994, p. 137-9).

Alguns dos discursos relacionados à colagem musical analisados apresentavam um estranho parentesco com a cena do livro de Carroll. A partir disso algumas investigações seguiram e me concentrei no papel do nome e do nomear. Inspirado pelos apontamentos de Ludwig Wittgenstein, procurei mostrar algumas confusões possíveis no uso dos nomes. Assim constatei quando essas confusões podiam ser usadas criativamente e quando efetivamente o foram.

Durante o período em que foi realizada a pesquisa assisti à série animada Neon Genesis Evangelion, escrita e dirigida por Hideaki Anno (1995-6). Impressionou-me como, nos seus 26 episódios, há uma mistura de elementos díspares, sem especial ênfase em nenhum deles; esses elementos aparecem nivelados, pouco hierarquizados, dispostos em relações horizontais entre eles. Argumentos filosóficos, questões existenciais, referências teológicas, personagens emocionalmente disfuncionais, cenas exageradamente dramáticas, cenas de comédia com tom infantil, cenas de guerra, gráficos fictícios sobre tecnologias igualmente fictícias, robôs gigantes, seres extraterrestres invasores que têm como objetivo destruir a Terra, sugestões de cenas eróticas, comédia de costumes japonesa; todos são colocados em um mesmo plano composicional. $\mathrm{Na}$ animação de Anno existe uma estética da ultrassuperficialidade, no sentido de que os elementos são apresentados todos numa mesma superfície, sem a criação de planos de contraste e relevo.

$\mathrm{Na}$ prática da colagem musical também há, por vezes, certa valorização da superfície. Elementos são retirados de seus contextos originais, sem grande cerimônia, e postos ao lado de outros, pertencentes a contextos inteiramente distintos. A escrita do texto procurou então valorizar essa possibilidade de movimento, incorporando ela mesma um pouco desse plano nivelado de composição, quanto à disposição e também à seleção e uso de elementos.

Segue um segundo sumário, que não possui caráter de índice. 
$\mathrm{Na}$ introdução apresento rapidamente o tema e o modo com que foi abordado. Comento sobre certas preocupações quanto ao estilo do texto e sua estruturação. Termino expondo este segundo sumário.

No capítulo 1 contextualizo o tema da dissertação. Começo mencionando muito brevemente o papel constitutivo que as práticas apropriativas têm na cultura humana em geral. Depois aponto alguns antecedentes em relação à colagem musical na música experimental. Faço-o a partir da tradição musical de concerto europeia. Em seguida elenco algumas práticas de colagem e apropriação do campo das artes plásticas. Faço uma breve cronologia da colagem musical na música eletrônica experimental, construindo assim um repertório de obras pertencentes ao escopo da pesquisa. Realizo um pequeno histórico relacionando obras do repertório da pesquisa e diversas tecnologias fonográficas.

Obras e projetos abordados, em ordem de aparição no texto: Ludwig van Beethoven - Sinfonia No. 9; Franz Schubert - Sonata para Piano em A menor, D.537 (tema); John Cage - Fontana Mix; John Cage - Imaginary Landscape No. 1; John Cage Imaginary Landscape No. 5; Pierre Schaeffer - Étude Pathétique (quinto dos Cinq Études de Bruits); Nam June Paik - Hommage à John Cage; James Tenney - Collage No. 1 'Blue Suede'; Karlheinz Stockhausen - Hymnen; Nicolas Collins - Devil's Music; Dickie Goodman - Flying Saucer; Negativland - It's All in Your Head FM; Paulo Loureiro \& Camilo Caropreso - Quinzé Anssim Num Quinzé Anssim Tumén; Bob Ostertag \& Fred Frith Voice of America part I; Milan Knížák - Composition No. 5 (do álbum Broken Musik); Phillip Jeck \& LOL Sargent - Vinyl Requiem; Sven König - sCrAmBIEd?HaCkZ!; Bob L. Sturm Concatenative Variations of a Passage by Mahler.

No capítulo 2 apresento noções e termos caros à pesquisa, em dez tópicos: música eletrônica; música experimental; música eletrônica experimental; colagem musical; sampleamento; plunderphonics; citação; arranjo; plágio; intermusicalidade. Investigo seus usos e também seus potenciais enquanto categorias. As categorias da música eletrônica, música experimental e a junção de ambas ajudam a melhor circunscrever o escopo da pesquisa. Os tópicos sobre colagem musical, citação, arranjo e plágio ajudam a localizar as diferenças significativas quanto às abordagens da prática da colagem musical. $O$ tópico sobre o plunderphonics trata da única manifestação que pode ser considerada um gênero, dentro do tema, justamente por ter um plano estético bem definido. Termino com um termo abrangente, a intermusicalidade, amplo o suficiente para acolher a variedade 
existente na pesquisa.

Obras, projetos artísticos e álbuns musicais abordados, em ordem de aparição no texto: Weasel Walter - Weasel Walter Plays Over Records; John Oswald - Dont; Danger Mouse - Grey Album; Girl Talk - All Day; Willy Corrêa de Oliveira - Prelúdio II; Tiago de Mello - Sem Título; The Residents - Swastikas on Parade; John Wall - Distill; John Cage William Mix; Mário Del Nunzio - Improviso em Branco e Preto e Vermelho (Carta às Videntes); John Oswald - Pocket; Jean-Pierre Caron - Momentum I (Para Giacinto Scelsi II); Noah Creshevsky - Hyperrealism; Luciano Berio - Sinfonia; Johannes Kreidler Universität der toten Philosophen (quinto movimento de 5 Programmings of a MIDIKeyboard); John Oswald - prelude; Negativland - I Still Haven't Found What I am Looking For - Special Edit Radio Mix; Pierre Henry - La 10ème Remix; Guilherme Rebecchi - O Rei dos campos de beterraba (sonata tan-sá).

No capítulo 3 trato da referencialidade, primeiro esclarecendo o que entendo pelo conceito. Diferencio autorreferencialidade e extrarreferencialidade, a fim de dar um caráter mais amplo à reflexão, que possa levar a pensar sobre o processo de estabelecimento de uma linguagem musical, daquilo que é próprio à música, e como as práticas de colagem podem problematizar essa noção. Lido com o reconhecimento, a fim de estabelecer limites para o estabelecimento de referências. No terceiro tópico diferencio fontes sonoras e fontes musicais. Comento sobre a possibilidade do timbre de estabelecer uma marca sonora e abordo a familiaridade, no que essa noção tem de implicações quanto à formação dos gostos musicais e à escuta. Amostras de músicas muito familiares são tratadas a partir da noção de gancho. Contraponho então outro tipo de familiaridade: aquele ligado ao pastiche e à percepção do que é genérico. Comento a possibilidade de referenciar temporalmente as diversas gravações de músicas. Abordo a questão da multiplicação da autoria consequente do uso de colagens musicais, que se apresentem enquanto tal. Observo a capacidade da referencialidade de articular argumentos e comentários, a partir das músicas, sobre diversos assuntos.

Obras abordadas, em ordem de aparição no texto: Otomo Yoshihide - The Night Before the Death of the Sampling Virus; Yasunao Tone - Solo for Wounded CD; John Oswald - Velocity (parte 12 de Plexure); Mário Del Nunzio - O Chá; Johannes Kreidler Product Placements; Luiz Eduardo Castelões - Estudos de plágio No. II: Thelonious Monk puzzle; Erik Bünger - Let Them Sing For You (2003); Henrique Iwao - Primeiro Acorde; John Oswald - Plexure; Richard Trythall - Omaggio a Jerry Lee Lewis; Henrique Iwao - 
Sobre a Pausa 04; Erik Carlson - Beethoven's Eroica: Opening Chords; Charles Dodge Any Resemblance Is Purely Coincidental; Noah Creshevsky - Red Carpet; Vladmir Ussachevsky - Wireless Fantasy; John Oswald - Pretender; Henrique Iwao - Baby; Alexandre Fenerich - Étude D'après Mahler.

No Capítulo 4 discorro sobre dois subtemas da dissertação. No primeiro, abordo correlatos musicais a práticas expostas brevemente no segundo tópico do primeiro capítulo: bricolagem, assemblagem, descolagem. No segundo, abordo o período pósmoderno, no que uma de suas caracterizações pode acrescentar ao panorama de motivações para a colagem musical. Trato-o segundo a tendência de indiferenciação entre as esferas do econômico e do cultural.

Obras abordadas, em ordem de aparição no texto: Pierre Schaeffer - Étude Pathétique; Johannes Kreidler - Compression Sound Art; Pan\&Tone - Peter Francis Tribute; Mieko Shiomi - Water Music; Otomo Yoshihide, Mats Gustafsson, Mikito Ozeki With Records; Louis Andriessen - In Memoriam; Rodolfo Caesar - Fuga No. 3 de Bach/Busoni/Caesar, Luciano Berio - Sinfonia (terceiro movimento); Bernd Allois Zimmermann - Photoptosis: Prélude for Large Orchestra; Bernard Parmegiani Pop'ecletic; James Tenney - Collage \#2 ("Viet Flakes"); John Oswald - Spring.

$\mathrm{Na}$ conclusão realizo um brevíssimo resumo do que foi intentado nos capítulos 1 a 4 . Reforço a preocupação com a diversidade musical, fator que orientou esta dissertação. Discuto quatro motivos para minha inclinação à consideração que a colagem musical esteja sendo mais praticada no presente. Concluo com uma relação entre colagem musical e o caráter incompleto das práticas musicais. 


\section{Capítulo 1: Prólogo}

A colagem musical é uma forma de apropriação; como tal, pode ser comparada a outras formas, como a citação, a incorporação, a alusão. As comparações poderiam ir tão longe quanto o conhecimento e imaginação do comparador, a fim de mostrar como a cultura se desenvolve a partir de práticas de apropriação. Poder-se-ia começar com exemplificações que vão desde a antiguidade grega, das práticas do tempo de Homero ${ }^{1}$, passando pela apropriação de formulações de outros filósofos por Platão, até as fotomontagens dadaístas; das diferentes tradições dos modos de fazer populares e cotidianos, até a constituições de gêneros artísticos, rumo às práticas de compartilhamento de informações e arquivos através da internet ${ }^{2}$. No caso da música não seria diferente; elencar-se-iam modos nos quais os músicos utilizariam diversas formas de apropriação, chegando até as práticas de sampleamento e colagem musical.

Neste estudo, entretanto, opto por algo mais simples. Primeiro aponto alguns antecedentes dentro da tradição musical de concerto europeia, a fim de elucidar a presença de certos tipos de práticas de apropriação que irão desembocar na produção de obras que usam colagens musicais, explícita e consistentemente, na década de 1960. Deste modo, nota-se que a colagem musical não ocorre exclusivamente no âmbito da música eletrônica, dada sua presença na música instrumental de concerto ${ }^{3}$. Também, algumas comparações entre músicas eletrônicas e não-eletrônicas, feitas ao longo do trabalho, serão minimamente contextualizadas.

Em seguida algumas formas de apropriação e colagem de outras áreas artísticas

1 "Os poemas homéricos contêm discursos convencionais (tais como aquele feito por um general para suas topas antes da batalha) e descrições de situações típicas. Os discursos e as descrições são repetidos palavra por palavra quando surgem circunstâncias semelhantes. Os poetas homéricos não estavam interessados em produzir expressões novas e 'originais' para as mesmas velhas coisas. Eles queriam o melhor estereótipo para uma situação determinada e, quando o encontravam, repetiam-no sempre que aquela situação ocorria."; p. 119: "Não há nenhuma verdade abrangente que vá além de uma enumeração de detalhes, mas há muitas informações, obtidas de várias maneiras, de fontes diferentes e reunidas para beneficio dos curiosos. A melhor maneira de apresentar esse conhecimento é a lista (...)" (FEYERABAND, 2010, p. 155. Adeus à Razão). A construção poética típica, no tempo de Homero, se dá, em grande parte, por adição de trechos compartilhados e fórmulas, e por procedimentos de listagem (sem dúvida, formas mais ligadas à noção de apropriação do que da de "gênio criativo").

2 Felix Stalder, por exemplo, no filme Steal this Film 2 (King, 2007), chega a declarar sobre a prática de apropriação da cópia: "Basicamente o que nos mantém juntos é que copiamos uns dos outros."

3 Tampouco é exclusiva à música de concerto, também ocorrendo nas formas e gêneros populares. Não obstante, estas não serão aqui abordadas, por parecerem, em princípio, distantes de nosso objeto de estudo. Vale ressaltar que a manipulação de discos no gênero rap é considerada uma manipulação da música eletrônica. 
que não a música são brevemente elencadas. No caso das artes plásticas, interessa algum aprofundamento em relação às práticas do papier collé, ligadas à pintura dita cubista; à fotomontagem dadaísta; às práticas de colagem e bricolagem de Kurt Schwitters e seus desdobramentos em alguns artistas do pós-guerra, tal como mencionado pelo historiador da arte Giulio Carlo Argan. Desta forma, será possível que estas breves considerações reverberem em exemplos musicais feitos mais à frente, podendo ser retomadas, via analogia, com a pergunta: como seria isso em música? Ou pela análise, em outro contexto, da temática, como será o caso da bricolagem.

Será feita também uma pequena cronologia dentro do âmbito da música eletrônica experimental, usando exemplos da literatura cujos procedimentos sejam próximos aos da colagem musical, incluindo obras sonoras realizadas por cineastas (frequentemente citadas na literatura). O aparecimento destas obras em outros textos é suficiente para atestar a importância desse repertório; não obstante, sempre que parecer esclarecedor, dados sobre os tipos de uso e contexto das obras serão fornecidos. Ademais, algumas das obras mencionadas serão abordadas em outros tópicos da pesquisa, aprofundando assim alguns aspectos das mesmas.

Por fim será realizado um pequeno histórico com alguns comentários concernentes às tecnologias empregadas nas práticas de colagem musical na música eletrônica, dado ser frequentemente mencionada a importância de algumas dessas tecnologias para o desenvolvimento e a popularização das práticas de colagem sonora. Em espaços urbanos saturados de música, a música é mais um elemento em uma paisagem carregada pela constante presença humana, em todos os âmbitos. Essa ocupação do espaço sonoro, mesmo que não seja o resultado direto da implementação tecnológica, se dá por meio desta. Com as tecnologias de reprodução do som se torna possível compor uma paisagem sonora urbana na qual um dos principais componentes sejam músicas na forma de gravações, reproduzidas de várias formas.

\subsection{Antecedentes na Música de Concerto Europeia}

Em Creative License, McLeod e DiCola (2011, pp. 45-6) apresentam alguns exemplos de apropriações dentro da tradição da música de concerto europeia: o uso, na Sinfonia no.1 de Brahms (1876), de frases da Sinfonia no.9 de Beethoven (1824); o uso, 
na introdução da Sinfonia no.3 de Mahler (1886), de um tema da Sinfonia no.1 de Brahms, transpondo-o para o modo menor, mas mantendo a estrutura melódica intacta; o uso intercalado de colagens de excertos de música de Tristão e Isolda (1859), de Wagner, e música no estilo ragtime norte-americano em Golliwog's Cakewalk, parte da suíte para piano Children's Corner (1906-8), de Claude Debussy; o uso de diversas canções estadounidenses bem conhecidas do público da época, em Flanders Fields (1917), de Charles Ives.

O termo uso, neste contexto, refere-se a um procedimento: o compositor emprega trechos advindos de outros compositores ou tradições musicais, apropriando-se delas de diferentes formas, seja aludindo às músicas, citando-as, realizando empréstimos nãocitacionais ou simplesmente tomando-as como ponto de partida, isto é, material inicial a ser manipulado e transformado. Há nos exemplos acima uma diferença de ênfase quanto à referencialidade: a alusão costuma agir analogamente à paráfrase (um recriar, um referir-se mais difuso e ambíguo); a citação, por sua vez, seria algo mais direto, como a incorporação de um tema, de um tipo específico de passagem de baixo, mantendo claramente sua identidade; o empréstimo, simplesmente o emprego de material musical advindo de outras músicas (o que, nesse trabalho, equivale a uma das acepções do termo colagem musical, exposta mais à frente). Serão feitas mais adiante mais considerações sobre essas nuances. Tomando dois exemplos retirados da lista acima disposta, Debussy estaria mais próximo da prática de citação, e Mahler da alusão.

A Sinfonia no.9 de Beethoven é um exemplo central dentro dessa tradição aqui abordada. Curiosamente, ela traz em sua forma a recapitulação de trechos dela mesma, como reaparições ${ }^{4}$ ou colagens musicais, no início do quarto movimento. $O$ trecho apresenta uma relação complexa: mostra a princípio uma maneira de articular a grande forma de uma obra sinfônica, com recapitulações literais. Não pode, entretanto, ser tomado literalmente como uma forma apropriação, sem evocar uma relação esquizofrênica com aquilo que supostamente já pertenceria ao compositor. Ter-se-ia de pensar que o próprio compositor não é detentor de seus próprios resultados composicionais - que a partitura não é suficiente para fixar a criação e garantir o estatuto do autor; que é preciso reforçar essa pertença. Nessa hipótese, a autocolagem implica pegar para si, enquanto o compor algo original implica apenas o criar, o ser tomado pela escritura, ser tomado pelo ato de compor. Especulações à parte, talvez, no fundo, seja

4 No caso da escuta da obra, o trecho pode ser interpretado tanto como uma reaparição quanto como uma rememoração, talvez uma mistura fantasmática das duas. 
uma questão do que pertence à música; que a Sinfonia no.9, neste determinado ponto, precisa invocar suas partes, impedindo-as de figurarem como movimentos autônomos.

Outro exemplo que poderia ser encarado como autocitação, mas que toma outros matizes, está no movimento Allegreto quasi Andantino da Sonata para Piano em A menor, D.537 (1817), de Franz Schubert: assombrado pelo tema, o compositor o retrabalha. Utiliza-o então, novamente, no quarto e último movimento da Sonata para Piano em $A$ maior, D.959 (1828), Rondo: Alleggreto - Presto. Segundo Fisk (2001, p.281). Nessas últimas sonatas para piano de Schubert, em suas perambulações de compositor, há "uma urgência em revisitar um reino da experiência uma vez atravessado (...), em experienciálo novamente na esperança de uma transformação catártica e reconciliatória deste" (idem).

Essa ciclicidade é um trabalho que poderia ser encarado como de metacomposição, remetendo tanto à citação musical, como às formas da variação, a diferentes arranjos e ao seguinte estribilho: poderia ser diferente, há inúmeras possibilidades. Se o que foi feito pelos próprios compositores não lhes pertencem por vezes, então o mesmo dar-se-ia com aquilo feito por outros: são temas, fragmentos, excertos, linhas, harmonias e acordes. Alguns deles parecem esperar pela apropriação por outro, mesmo que não referenciem sua fonte original. A própria forma variação parece requerer temas vindos de outrem, tanto para despertar o pegar para si do compositor em relação ao que vem do outro, quanto para colocar um o que importa é o que se faz com, e não o material em si. São exemplos: de Bach, Oferenda Musical (1747), sobre um tema de Frederico II da Prússia (ou de alguém à sua disposição, há controvérsias); de Beethoven, 33 Variações numa Valsa de Anton Diabelli, Op. 120 (1923), em cima de uma valsa de Diabelli; de Brahms, Variações Sobre um Tema de Haydn (1873), com um tema atribuído a Haydn, embora também com controvérsias quanto a autoria. Outro caso de interesse é de Stravinsky que, a pedido de Sergei Diaghlev, modernizou em Pulcinella músicas atribuídas a Giovanni Pergolesi (também há contrassenso quanto à autoria do que foi apropriado). O que em outras ocasiões poderia configurar-se meramente como versões e arranjos, toma vida própria.

A propósito da apropriação, a Igor Stravinsky são creditadas duas frases elucidativas: "Tudo o que me interessa, tudo o que eu amo, eu desejo fazê-lo meu" (WATKINS, 1994, 342, tradução nossa)5; e "um bom compositor não imita; ele rouba"

5 Watkins apresenta, em seu livro Pyramids at the Louvre: Music, Culture, and Collage from Stravinsky to the Postmodernists (1994), inúmeros outros exemplos de obras que utilizam-se de apropriações 
(OSWALD, 2004, p.136). Sua fase neoclássica é cheia de empréstimos tomados de outros compositores, sejam ligados ao material, sejam ligados ao estilo (modelos formais e formas de fazer). Ferrucio Busoni, por sua vez, baseou boa parte de suas peças em obras de Johann Sebastian Bach, como é o caso da obra Fantasia Contrappuntistica (1910); além disso, realizou diversas transcrições de obras, como a da Chaconne da Partita No. 2 em D menor para violino, BWV 1004, realizada em 1883, para piano, também transcrita para orquestra, em outra versão. No artigo $O$ Valor da Transcrição, comenta: "A notação já é em si a transcrição de uma ideia abstrata. No momento em que a caneta assume sua função o pensamento perde sua forma original" (BUSONI, 1987, p. 87).

Michael Finnissy, compositor inglês, retoma as considerações de Busoni sobre a transcrição, chegando a declarar, em entrevista (FINNISSY apud Del Nunzio, 2006, p.3):

Frequentemente, mesmo em peças que não considero transcrições, pego
o material de algum outro lugar, pois, como ter uma ideia original em algo
tão socialmente determinado como música? Todas as notas foram usadas
antes, todas as combinações foram usadas antes, então na melhor das
hipóteses pode-se enganar a si mesmo que se está começando do zero,
mas você nunca está.

Desta forma, estabelece uma estética francamente baseada na apropriação de músicas alheias, como um modo de: i. reagir aos diversos estímulos musicais existentes; ii. tornar a sua produção musical mais acessível (trazendo os materiais utilizados como elementos familiares, aos quais o ouvinte pode apoiar sua escuta para melhor penetrar em terrenos desconhecidos); iii. enfatizar os processos composicionais envolvidos e não os materiais (achando novos modos de tratar velhos materiais); iv. desenvolver uma fluência técnica que permita manusear qualquer material musical (uma preocupação com um virtuosismo composicional). Del Nunzio, em seu estudo (idem, p. 7-9), faz constar uma lista de obras de Finnissy, relacionadas segundo o compositor do qual originou o material musical trabalhado. Cito exemplos não corriqueiros, no que concerne aos compositores referenciados: Jacob Obrecht (c. 1450-1505), em Obrecht Motetten I-V (1988-92); Niccolò Paganini (1782-1840), em Alkan-Paganini (1997); Percy Grainger (1882-1961), em Grainger (1979); George Gershwin (1898-1937), em Gershwin Arrangements (1975-88).

Essa abordagem de Finnissy também tem afinidades com alguns aspectos da obra de Henri Posseur, compositor nascido 17 anos antes (em 1929), autor da fantasia variável 
no gênero ópera, Votre Faust (1961-8), em que utiliza um amplo feixe de referências: Orfeu (1607), de Monteverdi, Messias (1741), de Haendel, Don Giovanni (1787), de Mozart, Fausto (1856-59), de Gounod etc.

Galliari (1995) traça um panorama da prática citacional na música de concerto europeia, de Beethoven a Zimmermann, constituindo assim uma direcionalidade rumo à incorporação inequívoca de trechos inteiros de música de outrem. Como exemplos: a supracitada Variações Diabelli (nome popular da obra), que cita um tema de Don Giovanni, de Mozart; o Episódio na Vida de um Artista, Sinfonia Fantástica em 5 Partes (1830), de Hector Berlioz, que usa o Dies Irae (melodia gregoriana tradicional, provavelmente do século XIII) - este canto é utilizado em um número grande de obras, incluindo a Dança Macabra (1874), de Saint-Saëns; a Marselhesa (1792), de Rouget de Lisle, na Abertura Solene para o Ano de 1812 (1880), de Tchaikovsky; a cantiga de ninar Frère Jacques (transposta para o modo menor), na Sinfonia No. 1 (1888), de Mahler; a já citada Pulcinella, de Stravinsky, "o cleptômano"6; B.W.V. (1973), de Geroges Arpeghis, em cima de obras de Bach; e Ludwig Van (1969), um filme de Mauricio Kagel, usando amplamente obras de Beethoven.

A obra de Bernd Allois Zimmermann emprega, segundo o autor, empréstimos não apenas de materiais heterogêneos, mas também de formas (clássicas, barrocas, populares, jazzísticas etc.); elas simbolizariam a simultaneidade da consciência temporal humana: a coabitação das realizações do passado no presente. Obras relacionadas por Galliari incluem: Capriccio (1946) e Photoptosis (1968), que será brevemente analisada em outra parte deste estudo. Por fim, o autor também menciona o terceiro movimento da Sinfonia (1968), de Luciano Berio, obra que receberá alguns comentários em relação ao estatuto da citação e da colagem, e à formulação de um discurso modernista, em tópicos outros.

Afora esses exemplos, é importante mencionar também a série Europera, de John Cage, com cinco obras, compostas entre 1987 e 1991. Segundo Stefan Beyst (2005), tratam-se de músicas produzidas usando fragmentos de óperas dos séculos XVIII e XIX: música encontrada [ready made music, musique trouvée]. Nas palavras de Cage: "Por duzentos anos os europeus mandaram-nos suas óperas. Agora as retorno todas para eles" (idem).

6 Conforme a brincadeira do próprio Galliari (1995). 


\subsection{Colagem nas Artes Visuais}

O termo colagem foi muito utilizado para descrever algumas práticas das artes visuais, de Schwitters e Braque a Rauschenberg e Warhol. Alguns músicos citam essas práticas como fonte de inspiração e motivação para seus trabalhos. O grupo Negativland menciona "a busca por criar obras de áudio segundo a tradição das colagens de imagensencontradas" (1995, p.22). Richard Trythall (apud Cutler, 2004, p.148-9), autor da peça Omaggio a Jerry Lee Lewis (1975), comenta:

Como a mesa ou o jornal em uma pintura cubista, o objeto familiar serve ao ouvinte como um ponto de orientação em meio ao labirinto de novos materiais... as manipulações de estúdio... carregam o material inicial para novas e inesperadas áreas, enquanto mantém as suas associações anteriores.

Russell Ferguson (2003, p.40), para falar da obra de Christian Marclay, liga o procedimento do objet trouvé (objeto encontrado) à utilização de gravações como material composicional. Diz ele:

Por sua própria natureza, a música gravada tem a tendência de carregar com ela um resíduo inabalável de seu contexto original. A obra de Marclay, então, tende a rondar entre os polos convencionalmente definidos da criação original e da apropriação Duchampiniana.

Golding (1991, p.46) descreve a chamada colagem cubista, fazendo uma distinção entre "colagem, a qual pode ser descrita como a incorporação de qualquer material estranho à superfície do quadro", descoberta por Pablo Picasso, e o papier collé, "uma forma particular de colagem, em que tiras ou fragmentos de papel são aplicados à superfície da pintura ou desenho", descoberta por Georges Braque. Essas descobertas datam de 1910-11, mas ambos os pintores não voltariam a essas técnicas após $1914^{7}$. Sobre o papier collé - nome pelo qual as colagens cubistas foram chamadas genericamente - declara Picasso (Golding, 1991, p.47) a François Gilot:

A finalidade do papier collé foi dar a ideia de que diferentes tipos de textura podem participar de uma composição para obter-se na tela a realidade da pintura, que irá competir com a realidade da natureza. Tentamos livrar-nos

7 Segundo Clement Greenberg (1996, p.87). 
do trompe l'oeil $l^{8}$ para encontrar um trompe l'espirit... se um pedaço de jornal pode converter-se numa garrafa, isso também nos dá algo para pensar a respeito de jornais e garrafas. Esse objeto deslocado ingressou num universo para o qual não foi feito e onde, em certa medida, conserva a sua estranheza. E foi justamente sobre essa estranheza que quisemos fazer que as pessoas pensassem, pois tínhamos perfeita consciência de que o nosso mundo estava ficando muito estranho e não exatamente tranquilizador.

Nesse relato, entretanto, não há menção à utilização de materiais que façam referência a outras pinturas, a outras obras. A incorporação de tecidos, jornais e tipos se dá como textura e modo de estabelecer contato com a realidade e incorporá-la (neste caso, o fora da pintura). A analogia mais apropriada com música seria a utilização de objetos ordinários como instrumentos musicais, e de objetos sonoros estranhos a uma tradição musical, inseridos heterogeneamente em uma música que acolheria essa heterogeneidade mantendo alguns elos com a tradição.

Já a postura de incorporação dos dadaístas, ao realizar suas fotomontagens (a partir de 1918), se atém menos a uma pesquisa sobre o suporte da pintura - isto é, a tela, propondo incorporações mais diretas de conteúdo (figuras e imagens). Hannah Höch, (apud CHIPP, 1998, p. 401) declara em entrevista:

Todo o nosso objetivo consistia em integrar os objetos do mundo das máquinas e da indústria ao mundo da arte. Nossas colagens tipográficas, ou montagens, pretendiam realizar isso impondo, sobre uma coisa que só podia ser feita a mão, a aparência de uma coisa que havia sido totalmente feita a máquina. Numa composição imaginativa, costumávamos reunir elementos retirados de livros, jornais, cartazes ou folhetos, num arranjo que até então nenhuma máquina podia compor.

Há um possível parentesco aqui com obras eletroacústicas de John Cage, como a versão eletrônica de Fontana Mix (1958): a mistura entre montagem manual (operações envolvendo cortar e colar usando fita magnética), objetos do mundo das máquinas (fonogramas diversos, gravações de música), e aparência inumana (procedimentos aleatórios formatando a composição e montagem da obra).

Giulio Carlo Argan (1992, p.360) comenta sobre o trabalho de Kurt Schwitters, artista também ligado ao movimento dadaísta alemão:

8 Algo como engana olhar. Na pintura, a expressão frequentemente se refere a uma técnica na qual pretende-se apresentar uma representação da realidade como a realidade, isto é, criar-se a ilusão no observador de que se trata da realidade e não de uma representação desta. 
As coisas recolhidas e combinadas por Schwitters, no quadro que vem compondo, foram descartadas pela sociedade por não servirem mais, por terem cumprido suas funções; nem assim deu-se ela ao trabalho de destruí-las, pois, para a sociedade 'de consumo', a realidade se divide entre o a consumir e o consumido. Não há nada de lastimável ou patético no gesto de recolhê-las, e não porque este venha a revelar sua beleza secreta e ignorada. Mas, por serem coisas 'vividas', comporão no quadro, com outras coisas igualmente 'vividas', uma relação que não é a consecutio lógica de uma função organizada, e sim a trama intricada e, no entanto, claramente legível da existência. Ou, talvez, do inconsciente que, como motivação profunda, determina o fluxo incoerente da vida cotidiana.

Argan também aborda a chamada bricolagem, que teve Schwitters como precursor, citando as obras de Arman, Raymond Hains, Mimmo Rotella, Daniel Spoerri, (que começaram a atuar dessa forma no final da década de 1950, início da de 1960): a coleta e posterior ''apropriação' de coisas que pertencem ao contexto fenomênico do mundo moderno" (idem, p.558); o acúmulo destas (assemblage - de colheres e pratos, de carros, em Arman, a objetos de cozinha em Spoerri); a apresentação desmembrada das mesmas (dissemblage - os violões desconstruídos e empilhados de Arman); a deterioração dos elementos (décollage - em especial: cartazes de Rotella; colagens de anúncios cortados e danificados, feitas Hains).

\subsection{Pequena Cronologia}

Antecedentes envolvendo utilização de gravações como material para composição e/ou performance são fornecidos por Cutler (2004, p.145): em 1920 Stefan Wolpe usa oito gramofones para simultaneamente tocar discos a velocidades diferentes, durante um evento Dada; Ottorino Respighi pede o canto de um rouxinol gravado em disco de acetato, para o poema sinfônico Pini di Roma (1924); Paul Hindemith e Ernest Toch produzem Grammophonmusik (1929-30), três estudos gravados ${ }^{9}$; John Cage, usando gravações de tons de teste, em Imaginary Landscape No.1 (1939).

Utilizando gravações, e montando-as em filmes cinematográficos, cineastas se aventuraram também em montagens sonoras: Walter Ruttman, em Weekend (1928); Fritz Walter Bischoff, em Hallo! Hier Welle Erdball (1928); Grigori Alexandrov, em A Sentimental

9 Há uma leve disparidade entre fontes. Segundo lazzetta (2009, p. 141), Paul Hindemith criou duas peças sob o título Trickaufnahmen, e Ernest Toch, três sob o título Gesprochene Musik. Ambas faziam parte do Grammophonmusik: trabalhos realizados gravando instrumentos e vozes em disco e produzindo peças pela alteração da velocidade de rotação e superposição dessas gravações. 
Romance (1930); Dziga Vertov, em Enthusiasm (1931).

Seguindo o quadro de Cutler, aproximando-se mais das colagens musicais propriamente ditas, quanto à música eletrônica, têm-se os primeiros experimentos de Pierre Schaeffer, usando discos de arquivos sonoros da rádio em que trabalhava (RDF, depois rebatizada de RTF). Dos seus cinco estudos de ruído, obras inaugurais do que viria a ser chamado música concreta, Cutler cita o Étude aux Torniquets (1948), embora seja o Étude Pathetique que irá utilizar gravações de música em seu material, como será abordado mais à frente. Em Imaginary Landscape No.4 (1951), John Cage pede o uso de 12 rádios, produtores de "objetos-encontrados sonoros" ${ }^{10}$; em Imaginary Landscape No.5 (1952), 42 discos a serem tocados em vários fonógrafos (gramophones); James Tenney, na sua obra eletroacústica pioneira Collage No.1 ("Blue Suede") (1961), usa como único material composicional uma gravação de Elvis Presley interpretando Blue Suede Shoes uma composição de Carl Perkins (1955); a segunda e última incursão de Tenney nesse sentido, Collage No.2 (Viet Flakes) (1967) ${ }^{11}$, usa fragmentos de diversas fontes musicais: música pop, clássica e tradicional asiática, já indicando a ideia de que os discos "ocultam e nivelam as suas fontes, discos como objetos não fazem distinção entre 'alta' e 'baixa' cultura, 'arte' e 'pop'" (CUTLER, 2004, 147); Stockhausen, em Opus 1970 (196912), usa diversas gravações de interpretações de obras de Beethoven; Richard Trythall, com Omaggio a Jerry Lee Lewis (1975), usa várias gravações feitas por Jerry Lee Lewis de Whole Lotta Shakin' Goin' On, a primeira delas lançada por Lewis em 1957.

Do lado da música dita popular, Cutler cita as montagens de estúdio, usando fita magnética, realizadas por Frank Zappa nos álbuns de 1967: Absolutely Free, Lumpy Gravy e We're Only In It For the Money (no qual consta um trecho de uma música gravada, do estilo surf music); também a peça Tomorrow Never Knows, dos Beatles, do álbum Revolver (1966); o álbum Third Reich and Roll (1975), do grupo The Residents; também deles, a canção Beyond the Vallet Of A Day In The Life (1977), composta montando excertos de gravações de canções dos Beatles; por fim, dá o exemplo de Cassiber, sua própria banda, com Start the Show, do álbum A Face We All Know (1989).

10 Aqui a colagem musical é indireta: os rádios em si só transmitem a programação das emissoras. Como músicas são transmitidas tanto quanto ruídos, informações e vinhetas, o resultado da composição inclui uma série de sons, alguns dos quais deve-se encarar como colagens musicais. "Objetos-achados sonoros" seria o equivalente sonoro ao objet trouvé, o ready made. Outra tradução para o português é "objeto-encontrado".

11 A data da obra aparece como 1966 em Polansky (1983, p. 144).

12 A data de criação, como consta no LP, é de 1969 (Stockhausen, 1969). No site do compositor, no catálogo de obras, Opus 1970 não é mencionada como obra independente e sim como uma versão de Kurzwellen (Kuzwellen mit Beethoven), mas sem atribuição de data (Stockhausen, 2010). 
Abordando a manipulação de discos de vinil, os trabalhos de Milan Knižák são mencionados, mas apenas como pano de fundo para a produção de Christian Marclay, cujas obras Maria Callas e Jimi Hendrix, do álbum More Encores (1989), e Record Without Cover (1985) são citadas.

O foco do artigo é a prática de John Oswald, por ele mesmo denominada de plunderphonics. Assim, é natural que tudo seja conduzido de forma a tomar suas peças como ponto de referência. A justificativa é dada pela ênfase do programa estético declarado por Oswald, e concretizado em algumas de suas peças. Segundo Cutler (2004, 141), "de todos os processos e produções que surgiram do novo meio da gravação, a pilhagem sonora [plunderphonics] é a mais autorreflexiva; ela começa e termina com o já tocado." As peças citadas de Oswald são: pertencentes ao EP Plunderphonic (1988), Pretender (usando a versão de Dolly Parton da canção The Great Pretender (1955), de Buck Ram, originalmente gravada por The Platters), Dont (a partir de Elvis Presley), Spring (usando gravações da Sagração da Primavera (1913), de Igor Stravinsky), Pocket (a partir de uma gravação realizada pelo jazzista americano Count Basie); e também ao CD Plexure, Plexure (1993) (a partir de uma quantidade enorme de fontes).

Acrescento a essa pequena cronologia, de outras fontes, outros exemplos históricos: de Vladimir Ussachevsky, Wireless Fantasy (1960), usando uma gravação de 1951 do prelúdio da ópera Parsifal, de Wagner (1882). De Karlheinz Stockhausen: Telemusik (1966), usando músicas folclóricas diversas; Hymnen (1966-7), usando gravações de hinos; Kurzwellen (1968), utilizando rádios de ondas curtas que recebem informações musicais diversas, às quais os músicos reagem de modo improvisatório, seguindo estruturas predeterminadas; Opus 1970 (1969), com o mesmo tipo de estruturação, mas usando diversas gravações de obras de Beethoven como material. De Bernard Parmegiani, Pop'eclectic (1968) e Du Pop a l'ane (1969), onde o compositor flerta com o rock e a música pop, sem deixar de utilizar também materiais derivados de música orquestral, entre outros sons; Revolution 9 (1968), do grupo The Beatles (composta por John Lennon), incluindo música do próprio grupo, mas também excertos de obras de Schumann e Sibelius, entre outras; Strathoven (1985) de Luc Ferrarri, que alude a um possível encontro de Stravinsky e Beethoven no estúdio do compositor; La Dixième Symphonie De Beethoven (1979) e sua nova versão La Xe Remix (1998), de Pierre Henry, a partir das sinfonias de Beethoven. De John Cage, Rozart Mix (1965), usando diversos loops de fita magnética, tocados em vários aparelhos reprodutores; Fontana Mix 
(1968), peça eletroacústica que usa colagens diversas; Roaratorio (1979), obra radiofônica que emprega música tradicional irlandesa, combinada com a declamação de textos de Cage realizados a partir da obra Finnegans Wake, de James Joyce, e sons relacionados ao texto do escritor.

O álbum Broken Musik (1979), de Milan Knížák, contém colagens de gravações de um toca-discos em funcionamento, a reproduzir discos - criados a partir de recortes de outros discos. Solo for Wounded CD (1995), de Yasunao Tone, documenta uma performance em que o compositor utiliza sua própria música gravada, Musica Iconologos (1993), em CDs preparados que pulam e engasgam em sua reprodução. Merzbow, em Batztoutai With Material Gadgets (De-Composed Works 1985 86), lançado em 1993 e contendo material remixado de trabalhos de 1985-6, usa músicas eletroacústicas e clássicos modernos da música de concerto instrumental como parte do material; John Oswald, em Grayfolded (1994), baseia-se em 51 performances da canção Dark Star pelo grupo Grateful Dead. De Bob Ostertag, Verbatim (1996) é feito a partir de gravações de performances do grupo Say No More, tanto de improvisações quanto da peças lançadas no CD Say No More in Person (1994). Mais exemplos: Martin Tétreault e Robert Le Page, com o álbum Callas: La Diva et Le Vinyle (1997), a partir de gravações de Maria Callas; Terre Tahemlitz, Resistance for Change (1998), usando uma canção antifeminista, Love You Just The Way You Are, de Billy Joel. John Wall, Construction I: Stat/Unt/Dist (1997-9), usando amostras de curta duração de obras de Richard Barrett, lannis Xenakis, Harrison Birtwistle e Mauricio Kagel, além de gravações de improvisos instrumentais feitas especialmente para a obra. Otomo Yoshihide e Christian Marclay gravaram um álbum em duo, Moving Parts (2000), realizando improvisos com toca-discos, usando várias gravações e depois editando o material; Erik Bünger realizou Let Them Sing For You (2003), um projeto de arte interativa para internet, que esteve disponível na plataforma SRc da Rádio Nacional da Suécia entre 2003-2011: o usuário escrevia algo a ser recitado pelo programa, usando colagens de trechos de canções famosas; Girl Talk, com o álbum Unstoppable (2004), radicalizando procedimentos do gênero mashup, mistura dezenas de canções de sucesso em um fluxo contínuo de música dançante; Negativland, no álbum de 2005 No Business, construído inteiramente a partir de procedimentos de sampleamento: Favorite Things, por exemplo, desconstrói a canção My favorite Things (1959), de Richard Rodgers e Oscar Hammerstein, tal qual aparece cantada por Julie Andrews no filme The Sound of Music (1965) (cujo título é, em português, A Noviça Rebelde). O projeto 
sCrAmBIEd?HaCkZ! (2006), de Sven König, um sistema de beat box: o performer canta, de modo ritmado, timbres percussivos; o programa, desenvolvido por König, procura pelos trechos mais parecidos em uma coleção de trechos de áudio de uma canção predefinida, em seguida reproduzindo os trechos escolhidos, acompanhados por fragmentos correspondentes do videoclipe da mesma canção. Johannes Kreidler, em Product Placements (2008), usa 70.200 amostras musicais em 33 segundos de música; Mário Del Nunzio - Vermelho (2008), usando canções de death metal [metal da morte] e várias versões d'A Internacional (1988), hino socialista, de Eugène Pottier e Pierre de Geyter; Thomas Bey William Bailey, em Progressive Lycanthropy (2007), usando canções do gênero black metal [metal negro], ligadas à temática do lobo.

\subsection{Tecnologias Empregadas}

O fonógrafo foi inventado em 1877 por Thomas Edison, e usava um cilindro de cera como mídia para gravar informações sonoras e reproduzi-las. Como o aparelho ainda não tinha uma função clara, Edison o encarou como um equipamento de documentação sonora, comparável à câmera fotográfica, dizendo: "[para] os propósitos de preservação da fala, das vozes e das últimas palavras de um membro da família que está a morrer como a de grandes homens - o fonógrafo desbancará inquestionavelmente a fotografia" (THOMPSON, 1995, p.135).

O aparelho adquiriu sua função de reprodutor de músicas apenas na década de 1890 , sendo oferecido para venda ao público geral em 1896, e se popularizando por volta de 1900, de modo que, nesta época, a música fonográfica já podia ser ouvida em bares [saloons] e hotéis ao redor dos Estados Unidos.

Houve, entretanto, resistência à popularização do fonógrafo. Uma das figuras emblemáticas dessa resistência foi o músico John Philip Sousa. O assunto é abordado também por Thompson (idem, p.139, tradução nossa):

Em 1906, ele declarava [que ocorria]: "uma deterioração evidente na música e gosto musical estado-unidense, uma interrupção no desenvolvimento musical do país, e um monte de outras injúrias para a música nas suas manifestações artísticas, por virtude - ou melhor, por vício - da multiplicação das várias máquinas de reprodução musical." Sousa temia a substituição do fazer musical pela escuta passiva; o gradual silenciamento da banda da cidade, do cantor amador e pianista, "até que 
apenas sobre o aparelho mecânico e o intérprete profissional." "Onde quer que exista um fonógrafo, o instrumento musical é desalojado. Será cumprido o tempo em que ninguém se disporá a submeter-se à disciplina enobrecedora da aprendizagem musical... Todos terão suas músicas já prontas [ready made] ou já pirateadas nos seus armários".

A fim de categorizar a música fonográfica, Sousa criou o termo pejorativo música enlatada [canned music $^{13}$ ], expressando assim seu desgosto pela disseminação da tecnologia fonográfica. O fabricante, por sua vez, para que o fonógrafo tivesse um nível de aceitação maior entre a população alvo, usou, como uma das estratégias publicitárias mais representativas, apresentar o fonógrafo como um instrumento musical. Esse instrumento, o fonógrafo, seria fácil de operar, e permitiria a recriação de sons diversos.

Em 1887 Emile Berliner inventou o gramofone, que operava usando o disco plano como mídia. Em 1895 já eram produzidos discos comerciais para o aparelho, e por serem mais resistentes e fáceis de manusear que os cilindros do fonógrafo, adquiriram maior popularidade, a ponto do fonógrafo cair em desuso. Somado a isso, os discos podiam ser mais facilmente produzidos em massa que os cilindros. Assim, a própria companhia de Edison passou a produzir aparelhos que tocavam discos. O termo fonógrafo, entretanto, não caiu em desuso, e designa, hoje em dia, ambos os aparelhos ${ }^{14}$. Ademais, fonografia, como termo, engloba as práticas que circundam a gravação de som, ou seja, é utilizado hodiernamente com um sentido bastante genérico, de área de atuação ${ }^{15}$.

$\mathrm{Na}$ década de 1920 o gramofone estava inteiramente popularizado, em vários centros urbanos. A capacidade que o usuário tinha de gravar seus próprios sons tinha sido perdida. Ela só reapareceria como opção com a fita cassete, na década de 1970. As questões de fidelidade de reprodução passaram a figurar em primeiro plano: se fosse possível não distinguir entre o som de uma cantora cantando presencialmente e a reprodução da gravação de sua voz, então estava provada a qualidade do aparelho. Nessa operação de aumento da fidelidade, o gramofone mantinha seu viés de armazenamento, documentação e reprodução de sons. Se era um instrumento, tratava-se antes de um instrumento musical reprodutor. Entretanto, muitos compositores das décadas de 1920 e 1930 procuraram justamente explorar o gramofone como possível

13 Curiosamente, quando Andy Warhol pintou as Campbell's Soup Cans [latas de sopa Campbell], na década de 1960, também a indústria fonográfica estava a distribuir seus certificados de venda platinum e gold, a fim de valorizar discos que vendiam um grande número de cópias. Consultado do site oficial da RIAA [Associação da Indústria de gravações dos Estados Unidos]. Informação disponível em: <http://www.riaa.com/goldandplatinum.php?content_selector=historyx>. Acesso em: 23 mai. 2012.

14 Opção também tomada por Kelly (2009, p.329, nota 1$)$.

15 Para um verbete sobre, vide http://www.ears.dmu.ac.uk/spip.php?rubrique145. 
fonte de produção musical, e não apenas como uma tecnologia reprodutora. Caleb Kelly (2009, p.103) cita alguns deles: John Cage, Percy Grainger, Paul Hindemith, Ernest Toch, Raymond Lyon, Darius Milhaud, László Moholy-Nagy, Edgar Varèse. Nessas experiências já eram realizadas manipulações envolvendo a alteração da velocidade de reprodução das gravações, a utilização de mais de um gramofone ao mesmo tempo, e a combinação de sons gravados e sons produzidos na hora.

Também nessa época, no final da década de 1920, foi introduzida a possibilidade de fazer filmes falados (combinando as imagens com sons gravados, sincronizados). Alguns cineastas, previamente mencionados, fizeram incursos num âmbito que hoje poderia ser descrito como cinema cego, ou um cinema para os ouvidos (isto é, filmes em que não há imagens projetadas, mas apenas som). No entanto, isso não se desenvolveu como um movimento maior, e os compositores (de música) só viriam a explorar um tipo de edição similar (como a de Walter Ruttmann, em Weekend) após o advento do gravador de fita magnética, a partir da década de 1950.

Voltando aos toca discos: John Cage, na já mencionada obra Imaginary Landscape $N .1$ (1939), usou dois toca-discos reproduzindo discos de sons de teste. Esses sons de teste eram frequências estáticas. Como Cage podia manipular a velocidade de rotação desses toca-discos, podia assim controlar a frequência dos sons de teste, realizando glissandos com eles. Soma-se a isso o controle da intensidade do som, através de variação do volume sonoro, e também o controle de quando os toca-discos seriam acionados. Dessa incursão resultou o uso do toca-discos como um oscilador, acessível a ele, na época.

As experimentações de Cage continuaram, e com Imaginary Landscape N.2 e N.3, além de Cartridge Music (1960), desenvolveram-se em uma direção que não será abordada nesse estudo: a modificação e manipulação dos toca-discos, de seus componentes, sem o envolvimento necessário de discos (e portanto, de gravações). Entretanto, como já mencionado, Imaginary Landscape N.5 (1952) ${ }^{16}$ utiliza 42 discos (a instrução de montagem diz "quaisquer 42 discos fonográficos"). Nesta obra Cage inclui como evento sonoro a reprodução (normal e/ou manipulada) de gravações de música; o resultado é então gravado em fita magnética; a música é realizada sobre suporte fixo. A primeira música eletroacústica realizada pelo compositor é fruto da execução destas instruções. Cage já estava há algum tempo nutrindo a ideia da aceitação de todos os sons

16 Conforme consultado em: <http://www.johncage.info/workscage/landscape5.html>. Acesso em: 28 mai. 2012. 
audíveis como possível material musical ${ }^{17}$; uma vez estipuladas estruturas organizadoras, que pudessem definir durações dos materiais, e tipos de articulação que podiam ser aplicados a estes, o material se via homogeneizado a priori: um evento, com uma duração, que se articula de um modo genérico. Assim, na definição da palheta sonora de uma peça, poder-se-ia incluir aqueles sons advindos de gravações de músicas.

Essa expansão do potencial musical de todos os sons inclui gravações de música como um meio tanto de incorporar sons do ambiente urbano (já naquela época os ruídos da cidade incluíam toca-discos funcionando) quanto de estabelecer um viés crítico com relação à tecnologia - os discos não devem ser escutados passivamente; os toca-discos não são mero reprodutores.

Pierre Schaeffer realizou suas primeiras obras musicais na estação de rádio de Paris (RDF, depois rebatizada RTF). De 1948 a 1951 ele trabalhou usando discos. Tinha à sua disposição uma máquina que gravava em disco. Nessa época Schaeffer desenvolveu a técnica que chamou de Sillon fermé [sulco fechado], em que um som curto era gravado em um sulco que completava um círculo inteiro no disco, ao contrário das espirais normais, fechando assim o ciclo da gravação do disco sobre si mesmo. Isso fazia com que o sulco fosse lido repetidamente e o som, assim, tocado repetidamente. Operando vários toca-discos ao mesmo tempo (frequentemente quatro), ele tinha à disposição uma espécie de máquina sampleadora no conjunto (Davies, 1996, p.7).

Em 1948, Schaeffer produziu os seus Cinq Études de Bruits [Cinco Estudos de Ruído]. Em 5 de outubro de 1948 foram irradiados pela rádio, evento inaugural daquilo posteriormente conhecido como musique concréte, o concert de bruits. Sobre esse período, escreve Palombini (1999), sobre a fatura do Étude Pathétique, dito das Caçarolas:

Trabalhando num estúdio de rádio um pouco modificado, Schaeffer empregou um prato para gravação de acetatos, quatro pratos para reprodução, um misturador de quatro canais, filtros, uma câmara de eco e uma unidade móvel de gravação. As técnicas empregadas envolviam variações das velocidades de gravação e reprodução, amostragem e edição de sons por manipulação do braço, fechamento em anel do sulco gravado, movimentação do disco em sentido reverso, modulações de intensidade, fade-ins e fade-outs. Os corpos sonoros amostrados incluíam, em pé de igualdade: seis locomotivas com vozes pessoais, para-choques e maquinistas regidos por Schaeffer na estação de Batignolles (a seguir combinados com sons pré-gravados de vagões em movimento); uma orquestra amadora respondendo à chamada afinativa de um lá de

17 Fato comentado em diversos artigos, vide Silence, Cage (1970). 
clarinete, ornamentado assim de fiorituras, na Sala Érard (a seguir combinada com improvisações pianísticas de Jean-Jacques Grunenwald, ao vivo, no estúdio); Boulez ao piano, em harmonizações clássicas,

românticas, impressionistas e atonais de um tema dado (a seguir cortadas, retrogradadas e montadas). Encerrando a série, uma mixagem ad libitum de objets trouvés reunia a música de Bali, uma gaita americana e uma embarcação fluvial francesa em torno da voz de Sacha Guitry - que a tosse da radialista interrompera $(. .$.

Em 1951 Schaeffer já vinha trabalhando com Pierre Henry; fundou o Groupe de Recherche de Musique Concrète (GRMC) e seu estúdio foi equipado com o gravador de fita magnética, tecnologia que emergiu no pós-guerra. Assim, Schaeffer e seguidores tomariam outro rumo (tanto em relação ao toca-discos quanto à difusão das obras através do rádio). Entretanto, nesses três anos iniciais, Schaeffer, o manipulador de toca-discos, pôde se estabelecer, a posteriori, como um DJ dos primórdios, como sugere o próprio Palombini. Se feita uma comparação sucinta, pode-se ver que Schaeffer e os manipuladores de toca-discos das décadas de 1980 e adiante tinham várias características de operação em comum: a utilização e manipulação de discos, do já gravado - deslocamento de função de aparelhos reprodutores para que se transformem em instrumentos musicais (com ênfase em aspectos de performance dos mesmos); mudanças de velocidade e sentido ${ }^{18}$ da reprodução dos sons; mixagem de sons de fontes sonoras e provenientes de discos diversos; o uso de repetições idênticas - em Schaeffer, o silon fermé, nos DJ's, o loop.

Davies (idem, p.7) cita outros compositores que lidaram com a manipulação de toca-discos na mesma época de Schaeffer, atribuindo a eles um trabalho menos consistente: Tristram Cary, em Londres, desde 1947; Paul Boisselet, em Paris, desde 1948; Raymond Chevreuille, em Bruxelas, e Mauricio Kagel, em Buenos Aires, desde 1950. A exploração dos discos e toca-discos continuaria durante as décadas seguintes, mas em segundo plano: os compositores passariam, de um modo geral, a trabalhar com a fita magnética. A fita permitia uma série de procedimentos que não eram conseguidos com a manipulação de discos de vinil. O processo de gravação e montagem era mais flexível. Pedaços de fita poderia ser cortados em vários tamanhos, controlando assim precisamente a quantidade de tempo de cada trecho sonoro. Quando era o caso, o material proveniente dos toca-discos era gravado em fita, como ocorre na supracitada

18 A palavra sentido pode ser entendida a partir das indicações horário e anti-horário, em relação a como o disco gira no toca-discos, com um sentido de reprodução: normal (para frente temporalmente, mas que antes se referia ao giro no sentido horário do disco), ou inverso (tocando o som de trás para frente, equivalente ao sentido anti-horário). 
obra de Cage, e também em uma das primeiras de Nam June Paik: justamente uma Hommage à John Cage (1959) [homenagem a John Cage], em que gravações de diversas obras são reproduzidas em velocidades alteradas, por toca-discos, e gravadas em fita magnética. Os ruídos do toca-discos funcionando podem ser ouvidos, assim como o impacto da agulha sendo colocada sobre o disco.

Assim, até sua digitalização na década de 1980, as técnicas dos estúdios de música eletroacústica (incluindo o que foi aqui chamado de música eletrônica e de música concreta) foram desenvolvidas para a mídia da fita magnética. Isso fez com que a produção deste período ficasse bastante especializada. Os compositores lidavam com fita magnética enquanto o público adquiria gravações em discos e, mais tarde, na década de 1970, também em fitas cassete. A maior reaproximação com os toca-discos, realizada por muitos artistas na década de 1980, entretanto, ocorre justamente quando o disco de vinil está já começando a decair em popularidade como mídia, devido à ascensão do CD digital. Talvez apenas recentemente, com a popularização dos computadores portáteis, os músicos criadores e o público estejam novamente utilizando ferramentas e mídias próximas às músicas eletroacústica e eletrônica experimental.

É curioso notar que a opção de James Tenney pelo material de sua primeira peça eletroacústica (uma gravação de Elvis Presley) tenha sido feita em razão das dificuldades enfrentadas para manejar as tecnologias disponíveis na época:

Eu tinha ficado profundamente emocionado pelas obras de Varèse, Déserts e Poème Électronique, e pela sua visão de que novas possibilidades musicais poderiam ser realizadas através das tecnologias eletrônicas. Em 1959 eu comecei a fazer trabalhos de graduação na Universidade de Illinois, atraído pelo fato de que eles ofereciam cursos em música eletrônica (talvez pela primeira vez no mundo). Sob a tutelagem generosa de Lejaren Hiller, eu comecei a trabalhar com o novo meio, mas primeiramente sem sucesso algum. Apesar de minhas expectativas iniciais, o caráter sintético dos sons produzidos eletronicamente pareciam resistir a todos meus esforços em usá-los de um modo que parecesse musicalmente satisfatório para mim. Collage N. 1 - "Blue Suede" surgiu, inicialmente como um ato de desespero frente às dificuldades, mas depois que começou foi completada em uma semana febril no estúdio. (POLANSKY, 1983, p. 144-5, tradução nossa)

Outro exemplo de interesse se relaciona à obra Telemusik, de Karlheinz Stockhausen: tendo disponível principalmente a técnica da modulação em anel e controles de amplitude, o compositor pôde formular e desenvolver uma ideia de 
modulação que desse conta de aproximar tipos musicais muito distintos e permitir a inclusão de trechos de músicas folclóricas (agora disponíveis na forma de gravações) dentro de um pensamento essencialmente formalista (advindo das práticas da corrente do serialismo). Assim, surgem os processos de modulação e intermodulação (modulação entre sons ou entre músicas) que Stockhausen utilizará também em Hymnen.

(...) Eu tenho tentado criar relações próximas entre esses fenômenos aparentemente tão heterogêneos - para ser preciso, através de vários processos de modulação. O conceito antigo de "modulação", a mudança para outra tonalidade, é aqui aplicada a estilos. (...) Eu modulo o ritmo de um evento com a curva de amplitude de outro. Ou eu modulo acordes, que eu mesmo produzo, com uma curva de amplitude de um cântico de um sacerdote [priest], e então eu modulo o cântico monódico (isto é, a linha melódica) de uma canção Shipibo, e assim por diante. Desta forma eu tenho, em Telemusik, unidas músicas de outras pessoas com a minha própria música pela primeira vez. (KOHL, 2002, p. 94, tradução nossa).

Esse tipo de técnica, de modular uma música por outra, ou uma música por determinados sons, tornar-se-á recorrente nas práticas de colagem musical, reforçada pela possibilidade do uso, em meio à tecnologia digital, da técnica do phase vocoder. A combinação de aspectos espectrais e de amplitude de fonogramas musicais com outros elementos acontece em diversas obras, e extensivamente em: Plexure (1993), de John Oswald, Vermelho (2008), de Mário Del Nunzio e Progressive Lycanthropy (2007), de Thomas Bey William Bailey.

O estúdio, enquanto meio para a produção de música tratado como instrumentário disponível, acolheu principalmente os compositores de música eletroacústica. Fora dos grandes estúdios ligados a universidades existiram, entretanto, casos de estúdios particulares. Um exemplo notável é o caso do grupo The Residents, que em seus primeiros trabalhos desenvolveu um modo de fazer música dependente das técnicas de edição, gravação e montagem. Sobre essa fase comenta Cutler (1993, p. 76, tradução nossa):

The Residents ironizou e processou o pop, misturando-o com elementos de outros gêneros. (...) O que era novidade era o fato de que The Residents procedeu não a partir de um conhecimento das várias 'regras' de construção, mas de uma familiaridade auditiva altamente desenvolvida. (...) esta nova forma cresceu diretamente das possibilidades inerentes à nova tecnologia e da vida do som como som gravado. 
Também comenta Jones, (1995, pag. 220, tradução nossa) "The Residents estavam mais interessados no campo da música popular como crítica social, e apoderaram-se de sua unidade mais básica e mítica, o disco de vinil, como livro didático."

O rádio também foi explorado enquanto tecnologia que abria espaço para inserção de material musical advindo de músicas gravadas, dentro de uma composição. Nas décadas de 1920 e 1930, Kurt Weill (apud IAZZETTA, 2009, p.137-8) chegou a advogar uma música que refletisse sobre o meio radiofônico - uma música radiofônica -, que procuraria desenvolver a vocação criativa deste meio. Diz ele, em um artigo sobre o meio do rádio:

Já não pode haver mais dúvidas de que as pré-condições para o desenvolvimento de um gênero artístico independente de igual estatura estão presentes aqui - um gênero que irá muito além de uma "reprodução" mais ou menos perfeita de conquistas artísticas anteriores. A significância artística do rádio só pode ser vista no desenvolvimento de um tipo especial de arte do rádio, e de modo algum em uma continuação do sistema de concerto que hoje prevalece.

Se o Concert de Bruits de Schaeffer em 1948 poderia oferecer algo nesse sentido, as posteriores incursões e inclusão da música eletroacústica como música de concerto (tocada em salas de concerto e outros ambientes fechados) não foram nessa direção.

Como instrumento, o rádio foi utilizado principalmente por John Cage (a supracitada Imaginary Landscape No.4, cuja partitura dá instruções de como operar doze rádios) e por Karlheinz Stockhausen, que pede um rádio receptor de ondas curtas em Kurzwellen (1968), Spiral (1968) e Pole (1970). Nesses casos, o equipamento funciona como um produtor de objetos-encontrados sonoros: as instruções indicam ações a serem realizadas usando o rádio, mas não o que será tocado, que depende muito do contexto (hora do dia, qualidade da transmissão e recepção do sinal, localização do aparelho para cada local, estações de rádio diferentes, em faixas de frequência diferentes). 0 resultado é então imprevisível, e o rádio gera essa imprevisibilidade. Em Cage os sons assim gerados são aceitos como se apresentam: a peça define durações e articulações, independentemente desses sons. Nas obras de Stockhausen os intérpretes reagem aos sons do rádio, moldando assim sua produção sonora aos sons emitidos pelo rádio, de várias formas. Esse modelo em que o intérprete interage com os sons será então transposto por Stockhausen para uma situação usando apenas gravações de obras de Beethoven, em Opus 1970 (1969). 
Outro exemplo é a obra Devil's Music (1985), de Nicolas Collins. Nela um rádio gera todo o material, em tempo real, que é armazenado e tocado em samplers ${ }^{19}$, durante a performance. Em um texto escrito sobre a peça, o autor diz: "Há tempos eu acredito que o rádio seja o sintetizador mais barato do mundo, e no entanto, o mais poderoso: pode-se encontrar qualquer som nele; a única questão é, você pode encontrar o som que quer, quando quiser?" (COLLINS, 2009, p.1). Nas inúmeras performances que o compositor fez da peça, essa imprevisibilidade provia a tensão necessária entre o que era predeterminado (o instrumentário e a maneira de lidar com o material) e o que variava (o conteúdo sonoro manipulado): "Devil's Music foi feita para o menestrel andarilho moderno: cada performance era diferente, tópica, extraída das ondas [de rádio] locais." (idem, p.3)

O imaginário do rádio está ligado à noção de virtualidade - as ondas estão sendo transmitidas pelo ar, basta captá-las. Essa virtualidade é também uma virtualidade da cultura - evoca hábitos de transmissão e escuta bastante difundidos, que ainda hoje influenciam a maneira como as pessoas escutam cotidianamente. A apropriação dessa forma de transmissão de conteúdo reflete e comenta mais o meio do rádio do que a própria informação transmitida. A desconstrução que se dá é feita a partir das formas altamente padronizadas que se instauraram em relação ao rádio e seus programas. Sons residuais, ruídos e estática aparecem e desaparecem; diferentes níveis de relação sinal/ruído são usadas como um possível parâmetro musical (do som transmitido por uma estação até seu desaparecimento). Stockhausen comenta, em 1968: "o compositor não busca mais uma 'música sua', própria a ele ou um estilo pessoal. Estamos cada vez mais conscientes do fato de que todo a Terra é uma única vila." (apud KOHL, 2002, p.94). Assim, mostra um desejo de pertencer a suposta comunidade global, unificada por presenças marcantes como o rádio e os toca-discos. Se os artistas são como antenas da humanidade, então Stockhausen, Cage e Collins estão, a partir desse partilhar com o público de tecnologias da época, captando coisas que normalmente passam desapercebidas: novas possibilidades. Musicalizam o próprio meio, seus ruídos próprios etc.; ou ainda: mostram seus potenciais musicais, como ele pode ser usado para criar músicas (em vez de reproduzi-las).

Apesar dos exemplos dados neste prólogo, é de se questionar se obras que utilizam rádios efetuam de fato procedimentos de colagem musical. Aqui a análise só pode dar uma resposta positiva ou negativa após a performance, pois não há como

19 Vide capítulo 2 , tópico referente a sampleamento. 
discutir a constituição de algo que se abre para o imprevisto quanto à constituição a ser investigada. Neste caso, é preciso esperar o fim dos acontecimentos e depois olhar pra trás, relembrar ou ouvir de novo a obra, determinar se o rádio captou essas outras músicas.

Quanto a uma arte radiofônica, tem-se a obra Roaratorio (1979) de John Cage, criada especificamente para o meio do rádio. Outros exemplos poderiam ser dados, mas essa atividade passou à margem da preocupação da maior parte dos músicos pesquisados. O grupo Negativland, entretanto, absorveu parte da estética radiofônica padrão em seu modo de atuar, seja pela constante utilização do procedimento falas em primeiro plano e música ao fundo, seja pelos cortes rápidos e radiojornalísticos, seja pela montagem que faz referência a práticas de entrevista e formas publicitárias, presentes no rádio comercial. Práticas radiofônicas já tinham sido incorporadas por Dickie Goodman: em Flying Saucer (1956), sua primeira incursão nesse âmbito, realiza uma paródia do clássico radiofônico de Orson Welles War of the Worlds [Guerra dos Mundos], alternando comentários sobre a invasão de alienígenas com fragmentos de músicas de sucesso da época, do gênero rock'n'roll, que por sua vez comentavam por meio da música ou da letra cantada o que fora falado. Negativland atua no mesmo sentido, mas enquanto Goodman se apoia firmemente em tom de comédia e práticas da música pop, Negativland acrescenta elementos satíricos, irônicos e sombrios às suas produções, com uma abordagem mais experimental.

Segundo o próprio site oficial do grupo ${ }^{20}$, desde 1981 Negativland realiza um programa de rádio semanal transmitido ao vivo às quintas-feiras na KPFA 94.1FM, em Berkeley, Califórnia, com duração de três a cinco horas. Nesse programa, chamado Over The Edge, é realizada uma colagem sonora espontânea, misturando chamadas telefônicas do público a vários tipos de sons-encontrados [found sounds]. Na turnê It's All in Your Head FM, realizada primeiramente em 2005, o grupo remonta um ambiente de estúdio radiofônico no palco de apresentação e realiza o show na forma de uma transmissão de rádio. O suposto programa apresentado tem como tema a inexistência de Deus. Um assunto que o rádio deveria tratar, como meio já decadente em termos de influência pública. A performance parodia e satiriza procedimentos das rádios comerciais e religiosas, propondo a tese da inexistência de Deus e procurando fornecer evidência para sustentá-la: usa, para tal, colagens de depoimentos e músicas diversas.

20 Na página ABOUT "OVER THE EDGE. Disponível em: <http://www.negativland.com/ote/>. Acesso em: 17 mai. 2012. 
Uma colagem espontânea de músicas era realizada, semanalmente, no programa radiofônico Quizéé Anssim Num Quizéé Anssim Tumém, no ar de 1997 a $2008^{21}$ na rádio Muda, uma rádio livre, montada dentro do espaço da Universidade Estadual de Campinas. O meio da rádio livre, ao contrário das rádios comerciais, permitia esse ambiente de livre experimentação e liberdade criativa. A partir da colaboração de Paulo Loureiro (Juju) e Camilo Caropreso (Plâncton), em 1999 o programa estabilizou sua identidade, combinando colagens musicais e intervenções vocais poéticas e guturais ${ }^{22}$. Caropreso (informação pessoal ${ }^{23}$ ) comenta:

É como se fosse um jazz radiofônico. A gente sempre deixou em aberto o que iria acontecer - nunca sabia o que ia acontecer, na verdade. O formato básico do programa, a técnica básica, é o que a gente chama de esquizofonia, que é basicamente você tocar várias músicas ao mesmo tempo. Mas não tocar várias músicas ao mesmo tempo a troco de nada. Como uma orquestra tem vários instrumentos, a ideia era que cada música fosse um instrumento diferente, que cada música complementasse a outra e isso virasse uma música só.

A gente refletia, meditava bastante e evitava certos tipos de combinações. Por exemplo, se colocasse dois sons de punk rock, duas baterias tocando em tempos diferentes ao mesmo tempo, fica horrível. Então a gente procurava pegar as músicas, colocar três, quatro, cinco, no máximo seis músicas. Fazia com que cada música preenchesse o vazio que a outra deixasse. Por exemplo, você pegar um concerto de violão do Villa-Lobos junto com música eletroacústica e no meio você põe alguns cânticos indígenas; ou até mesmo som ambiente, que eu gosto muito de gravar pois trabalho com meio ambiente, sempre viajo muito aqui pela amazônia; gosto muito de gravar o som na beira do rio, do riacho, de noite, o som da mata, enfim.

A fita cassete, enquanto mídia, foi utilizada para fins de colagem musical, mas sem consequências expressivas. Bob Ostertag, em seus primeiros experimentos com colagens sonoras na década de 1980, utilizava fitas cassete tocadas por toca-fitas portáteis comuns quebrados, cada um de modo peculiar, resultando em diferentes tipos de distorção na reprodução. Nessa época lançou um álbum contendo duas gravações de improvisos, um com Fred Frith (guitarra), e outro com Frith e Phil Minton (voz): Voice of America (1982). No início do primeiro improviso aparece muito claramente uma canção de protesto, em espanhol, contra a intervenção estado-unidense na América Central (tema que interessará grandemente Ostertag, que, na época - entre 1982 e 1988 -, abandonará momentanea-

21 Houveram alguns hiatos dentro desse período, mas também continuações após 2008. Felizmente, Caropreso gravou os programas em fita cassete. Algumas das gravações foram digitalizadas e estão disponíveis em: <http://soundcloud.com/quizeeanssim>. Acesso em: 15 jul. 2012.

22 Como o famoso grito "Sokobauno", apropriado de um poema do dadaísta Hugo Ball.

23 Caropreso, C. Mensagem recebida por <veetbhram@gmail.com>. 
mente a música a fim de exercer práticas jornalísticas e políticas na região). Aos poucos surge um objeto sonoro de caráter intermitente (como se o som transformado, que poderia ser o próprio fonograma da canção, estivesse cortado em fatias, intercalando som e silêncio, permitindo a variação da frequência de alternância entre ambos e a duração de cada fatia - um slicer ${ }^{24}$ ). Ele se integra mais à gravação; esta recede ao fundo e depois vem de novo à frente. O improviso acena para uma relação de cumplicidade para com a canção. A letra da canção, sua mensagem, se faz inteligível. Ademais, a Voz da América [VOA, Voice of America] é ainda hoje a instituição oficial de difusão externa de informações do governo federal dos Estados Unidos, operando em vários países, inclusive na América Central, através de sítios eletrônicos, canais de TV e emissoras de rádio ${ }^{25}$. A utilização desse nome no título do álbum reforça a ideia de um posicionamento político já existente no emprego das colagens musicais dentro dos improvisos. De uma relação de valorização das resistências locais contra a política intervencionista estadounidense.

Antes de lançar o EP Plunderphonic (1989), John Oswald, no início da década de 1970, criou o projeto das Fitas Misteriosas - Mistery Tapes, em seu Laboratório Misterioso [Mystery Lab]. Nessas fitas cassetes não são fornecidas informações quanto ao conteúdo: quem as realizou, quantas e quais peças estariam gravadas, o quanto originaram de colagens musicais, quais as referências; nada disso é mencionado. Ao contrário da prática subsequente do autor, o Plunderphonics, na qual o uso de gravações de músicas conhecidas como material composicional deve ser evidente e escancarado, nas Mystery Tapes há intenção de anonimato em relação à composição e ao material utilizado (OSWALD, 2001, p. 18) ${ }^{26}$. Se os dois projetos forem comparados - as Mystery Tapes e o Plunderphonics - pode-se dizer que refletem certas características que se associaram, respectivamente, a tecnologias da fita cassete por um lado, e ao sampler digital/disco compacto, por outro.

A cassette culture se estabeleceu na década de 1970, fortalecendo-se na seguinte. $\mathrm{Na}$ década de 1980, membros de uma rede composta por indivíduos, gravadoras independentes e grupos de arte (com alguma intersecção com os praticantes de mail art [arte postal]) trocavam e enviavam mensagens de áudio, gravações demo, lançamentos

24 Nome comercial atribuído a esse tipo de efeito.

25 Conforme site da mesma, <http://www.insidevoa.com/info/about_us/1673.html>. Acesso em: 31 mai. 2012.

26 Ver também Mystery Tapes Etc, texto atribuído a Terri Firm. Disponível em: <http://www.plunderphonics. com/xhtml/xlaboratory.html>. Acesso em: 31 mai. 2012 
obscuros e mix tapes (seleções de músicas e sons específicos que podiam ou não circundar algum tema). Nessas trocas ficava patente a valorização da criação e manutenção de uma comunidade em torno da música e da arte sonora, bem como práticas de difusão não centralizadas e de caráter pouco mediado. Também era característico que cada membro fizesse grande parte dos estágios da produção das fitas, realizasse gravações caseiras, distribuição via correio, arte gráfica própria e projetos colaborativos. Ademais, havia o ideal do faça você mesmo e uma tentativa de viabilizar uma comunicação mais imediata e menos sujeita a filtros e censuras prévias ${ }^{27}$. Era prática corrente nesse período receber por correio fitas diversas; gravar por cima de informações sonoras já contidas nas fitas; selecionar músicas para uma compilação, segundo um tom emocional específico, tentando comunicá-lo para um futuro ouvinte etc. Essas práticas permeiam as mystery tapes: uma seleção não ortodoxa de sons realizados misteriosamente, a fim de provocar o ouvinte curioso; sons que mostram e escondem. $\mathrm{O}$ ouvinte poderia também produzir sua fita, de modo parecido? $E$ essas modificações nesses sons, nessas músicas, removem a autoria original destas e a suspendem? Soam como um convite à imaginação, ao devaneio, mas também à ação: colaborar, decifrar, produzir.

O Plunderphonics, por outro lado, é uma prática na qual Oswald insiste que as fontes musicais sejam creditadas e que o ouvinte possa reconhecer a música original, mesmo quando a fonte sofre diversas modificações e se transforma em outra música. Na década de 1980 e na subsequente, os samplers digitais se popularizaram, assim como o rap, e passou a ser comum colagens musicais figurarem nos veículos de comunicação (especialmente o rádio), via artistas de rap (que cada vez mais utilizavam samplers). Apesar de boa parte dessas colagens possibilitarem o reconhecimento da fonte musical, não era comum creditar a fonte, por uma série de motivos que não cabem nesta pesquisa ${ }^{28}$. A opção de Oswald foi também uma reação contra essa omissão por parte

27 Um exemplo de relato que menciona uma comunicação direta, de troca de fitas entre três artistas que se tornaram conhecidos, é dado por GX Jupitter-Larsen (BAILEY, 2012, p. 238-9): "Em 1982 um artista postal em Texas passou uma de minhas gravações para Maurizio Bianchi, na Itália. MB então me contatou diretamente. Logo após isso MB contou a Merzbow sobre mim, e nós três começamos a trocar loucamente. De qualquer forma, foi pela minha correspondência com MB e Merzbow que eu finalmente me pluguei a uma cena que estava lentamente se tornando o que conhecemos hoje como Cassette Culture."

Tanto GX Jupitter-Larsen quanto The Haters e o Mystery Labs de John Oswald, contribuiram para a compilação PhonoStatic 10: Audio Collage, de julho de 1989. Disponível em: <http://psrf.detritus. net/volume/6/k10.html>. Acesso em: 01 jun. 2012.

28 O livro Steal This Music: How Intellectual Property Law Affects Musical Creativity discute o assunto, embora não exclusivamente (Demers, 2006). 
dos rappers e da indústria fonográfica da época. Em 1985, sampleamento e a questão do direito de propriedade intelectual para música entraram em pauta para Oswald, que começou a escrever sobre o assunto e a experimentar com os limites que a questão dos direitos autorais imporia à prática criativa musical (2001, p.22). Ademais, com a criação dos discos compactos (CDs), aumentou-se o alcance comercial dos grupos musicais mais conhecidos, ligados a grandes corporações, gerando maior concentração da distribuição e centralização da produção em torno desses artistas. O CD era também uma mídia mais passiva e, antes do gravador de CD estar disponível ao público, não permitia aos usuários (frequentemente tratados apenas como consumidores) gravar nem manipular gravações (isto é, antes da acessibilidade promovida pelos computadores pessoais). Assim, tal ambiente era bastante contrário à cultura da $\mathrm{k} 7^{29}$, que tinha um modelo descentralizado e colaborativo, que procurava se afastar das grandes corporações. Assim, o mistério das fitas misteriosas, na prática do plunderphonics, deu lugar a músicas de sucesso, maximamente reconhecíveis, manipuladas por Oswald sob o prisma de duas assunções: de que um grande sucesso pode, numa cultura de massas supostamente cada vez mais homogênea, ser reconhecido por um grande número de ouvintes; e de que, mesmo que a indústria tenha fornecido um padrão de difusão e escuta de música que prioriza um ouvinte passivo, um ouvinte-consumidor, essas músicas estão aí para serem desconstruídas, desfamiliarizadas, escutadas de diferentes modos e de maneiras criativas.

Levando a sério as especulações sobre a possibilidade de colagens musicais sem um autor bem definido, e aparentemente sem conhecimento da produção do Mystery Lab, o grupo Lt. Murnau (atuante entre 1980 e 1984, formado por Vittore Baroni e Jacques Juin) realizou desconstruções de gravações de músicas dos Beatles e lançou, na época, a fita cassette Meet Lt. Murnau. Usando máscaras, o grupo propunha que outros se apropriassem do nome Lieutenant Murnau e produzissem músicas usando essa identidade, conquanto estas fossem realizadas "remontando músicas existentes" como "uma banda fantasma atuando como vampiro, sugando vida do conjunto da obra de outros compositores" (BARONI, apud BAILEY, 2012, p. 194).

Sobre o caráter colaborativo da rede de fita cassete que participava, Vittore comenta:

29 Isso não implica que na década de 1990 a cultura do $\mathrm{k} 7$ tenha desaparecido, mas que ela, nesse relato, tenha sido deixada de lado, a fim de focar a emergência e dominância da mídia do disco compacto. 
Como a rede de arte postal, da qual eu faço parte há mais de 30 anos, o 'submundo da cassete' era basicamente um ambiente colaborativo, era de interesse mútuo manter a rede de contatos crescendo pacificamente (mais contatos, mais sons interessantes para trocar, mais chances de sermos ouvidos e e de vender alguns cassetes). Não havia competitividade, mas sim uma tendência de ajudar o outro de qualquer modo possível (por meio de colaborações musicais, resenhas em revistas etc.) Conflitos eram portanto reduzidos a um mínimo, e é assim que a participação em redes sociais [social networking] ainda funciona hoje." (idem, 204).

Hoje em dia há iniciativas que tentam resgatar mídias antigas, como modo de fazer circular gravações de música. A já mencionada obra de Thomas Bey William Bailey foi lançada recentemente no formato fita cassete, acompanhada de um livro (2010).

Alguns artistas, apesar do domínio que a fita magnética exerceu durante as décadas de 1960 e 1970, continuaram a explorar os discos e toca-discos, realizando músicas que utilizam gravações musicais como material. Nam June Paik, com as instalações de 1963 Random Access e Random Access (Schallplatten-Schaschlik), promoveu acesso fragmentário e descontínuo às obras disponibilizadas em disco e fita magnética, meios tipicamente lineares, quanto à reprodução da informação. Na primeira, o usuário/ouvinte, munido de um cabeçote de leitura, pode passear pelos diversos fragmentos de fita magnética colados nas paredes, em sentido normal ou contrário. Na segunda, vários discos giram sobre um mesmo eixo, em várias camadas; o braço do vinil é destacado e pode viajar livremente por todos esses discos. Sobre essas obras, Kelly (2009, p.139) comenta: "Ao requerir a participação da audiência para ativar os sons durante a exibição, Paik deixou clara a natureza ativa e não-transparente da mediação. Com acessos aleatórios aos dados, a audiência cria novas versões das gravações originais."

Em 1963, Milan Knížák começou a realizar experimentos com discos, riscando, colando fitas, pintando-os, expondo-os ao fogo, cortando-os e colando diferentes partes de diferentes gravações a fim de formar um só disco. Ele comenta que, na época, não tinha dinheiro para comprar muitos discos, e por isso começou a alterá-los, de modo a obter novas músicas. Nas séries de composições que integram o álbum Broken Musik (1979), o meio se faz ouvir, pronunciadamente, através de velocidades rápidas ou lentas demais; do ruído incessante da agulha passando sobre os pontos de junção entre os recortes de disco, criando um pulso ruidoso que articula as mudanças de conteúdo musical; do deslize eventual da agulha sobre as imperfeições no sulco dos discos. Em 
Composition No. 5 o ruído chega ao extremo, e há a escuta da demasia de recortes nos discos, ou a suspeita de que não há disco em certos trechos, quando a agulha parece arrastar no prato. O som carrega indícios, nesse caso, do abuso de seu meio tecnológico, uma agressividade material, muito além de apenas compor ritmos e texturas.

$\mathrm{Na}$ década de 1980, no Estados Unidos, lugar mais próspero que a Checoslováquia de Knižák, Christian Marclay, apontando para uma situação diferente, declararia em relação à disponibilidade de discos:

"Quando primeiro vim aos Estados Unidos, era comum ver discos quebrados nas ruas. Isto tirou a preciosidade do objeto.(...) Quando há excesso, quando há brechós [thrift stores] repletos de livros e discos a 25 centavos cada, isso te faz pensar diferentemente sobre os objetos." (KAHN, 2003, p.19).

Sua música utiliza vários toca-discos como instrumentos, com manipulações em toda sua extensão de possibilidades. Seus discos são frequentemente alterados, preparados e abusados, similarmente a Knížák.

Se, por um lado, Marclay aponta sua exposição a uma sociedade com excessos materiais como fator inspirador de seu desenvolvimento estético, por outro, na década de 1980 , os discos de vinil são a tecnologia comercialmente disponível mais acessível, e que propicia uma reprodução fidedigna de música. Isso implicava que marcas, arranhões, poeira e sujeira nos discos deveriam ser evitados a todo custo, e que tanto estes quanto o aparelho reprodutor, principalmente a agulha, deveriam ser tratados com cuidado e precaução. Assim, as práticas de Marclay se contrapunham à fetichização do vinil e à ideia da reprodução fiel de música, além de estetizarem os ruídos produzidos pelo meio tecnológico.

Embora tenha continuado a se apresentar com toca-discos, Marclay (GOTTSTEIN, 2008) deixa clara sua postura crítica em relação à tecnologia, desenvolvida nessa época. Em recente entrevista, de 2008, declara:

Quando comecei a fazer esse tipo de música com discos, as pessoas ouviam música no toca-discos. Então, era o meio da vez, o meio em que aquilo fazia sentido. $E$ também era um meio frágil, e que as pessoas entendiam. Elas entendiam sua fragilidade. Você tinha que cuidar dos discos com cuidado, tinha de espanar para garantir que não haveria poeira nele, e os arranhões eram tabu. Então eu estava brincando de monte com essas convenções e esses hábitos, e perturbando aquela ordem. E abraçando todos esses acidentes e danos e a fragilidade do disco. Então 
fazia mais sentido. Hoje em dia tudo é digital. Discos têm uma qualidade muito nostálgica, do vinil. Mesmo que sempre existam pessoas jovens redescobrindo o vinil, para mim não tem o mesmo impacto que eu teria quando eu quebrava um disco no palco e presenciava uma reação de 'ó!'. Hoje em dia é mais como 'é isso aí' [oh yeah]. É como quebrar uma guitarra numa apresentação. Não tem mais significado. É apenas um ritual.

A tecnologia do disco compacto, o CD, surgiu em 1982, e na década de 1990 o vinil não era mais popular, sendo utilizado principalmente por DJs e colecionadores. A performance Vinyl Requiem $(1993)^{30}$, uma colaboração entre o músico Phillip Jeck e o artista visual LOL Sargent, simboliza esse estado de coisas: em uma parede, muitos tocadiscos estão dispostos, de modelos antigos, que reforçam a ideia de que os toca-discos são uma tecnologia do passado, assim como os discos de vinil - uma tecnologia que morre enquanto mídia comercial dominante, e que agora passa a figurar como específica à produção artística. Os álbuns escolhidos também têm um pouco dessa característica: muitos são loops de música orquestral do repertório clássico e gravações já tidas como antigas, de uma música que pode ser considerada antiga. As texturas dos loops transparecem os resíduos sonoros produzidos pelos aparelhos, tanto quanto mudanças são por vezes articuladas pelo som do disco acelerando e desacelerando, um resíduo do processo de ligar ou desligar os toca-discos.

Libertado de seu apelo comercial proeminente, os toca-discos e discos de vinil finalmente passam a ter como função a criação musical. Tecnologia antiquada, não mais se ligam à busca incessante por transparência, por fidelidade sonora. Não figurando simplesmente como excentricidades, em debates sobre qual o melhor som, entre as tecnologias concorrentes, emancipam-se finalmente como instrumento musical. Seus resíduos sonoros, antes indesejáveis, agora são distintivos de sua qualidade; merecem até amplificação, a ponto de estarem por vezes mais altos, em intensidade, que as próprias gravações tocadas, como acontece nas práticas do grupo de música experimental Duo $\mathrm{N}-1^{31}$.

Assim, em uma trajetória tecnológica que fecha um ciclo, da criação do fonógrafo, com Thomas Edison, passando pelas críticas de John Phillips Sousa e pelos usos artísticos diversos (embora falte a menção, nessa narrativa, à utilização artística também por DJs), o toca-discos pôde se transformar em uma tecnologia que possibilita reintegrar

30 Um vídeo documental de uma das apresentações pode ser visto na internet. Disponível em: <https://vimeo.com/17439345>. Acesso em: 15 jul. 2012.

31 A faixa Surfing In Turntables, do disco enemenosvídeo, é exemplar nesse sentido. Disponível em: <http://www.limiares.com.br/duo-n1.html>. Acesso em: 13 mai. 2012. 
a prática dita de músico amador. Em 2003, na introdução do Leonardo Music Journal, Nicolas Collins (2003, p.1) declara:

\begin{abstract}
A informação saliente, repetida nas mídias musicais e de massa [mainstream], em páginas de internet e até mesmo em uma estranha dissertação de doutorado, foi que em 1999 tinham sido vendidos mais toca-discos do que guitarras. A notícia era ainda mais notável dado que veio num tempo em que o LP de vinil tinha sido quase universalmente suplantado pelo $C D$ como formato de distribuição e consumo de música. Esses toca-discos não estavam sendo comprados para serem armazenados por uns poucos puristas do vinil, em antecipação à escassez futura; eles foram comprados por Disco Jóqueis. Eles não foram comprados para que se escutasse a gravações, mas para tocá-las [to perform records].
\end{abstract}

Em uma redefinição da tecnologia, os toca-discos passam a figurar como instrumentos que atendem às demandas musicais dos tempos hodiernos: mixar, combinar, reutilizar gravações. Aí também ressurge a figura do músico amador, com o DJ amador e seus toca-discos e discos de vinil. Alguém poderia dizer: se eu quisesse simplesmente ouvir música, utilizaria outra mídia, um CD, meus arquivos MP3. Com os vinis, eu toco música.

No entanto, o toca-discos não é a única tecnologia fortaleceu a tendência ao uso de colagens musicais. Com a tecnologia digital surgiram os samplers digitais. Antes disso, entre outros exemplos, Schaeffer já havia patenteado um sampler que funcionava com fita magnética: o phonogene (1953). Os primeiros sampleadores digitais apareceram em 1971 (DAVIES, 1996, p.8 e p.11). Mais tarde, entretanto, se tornaram mais amplamente importantes enquanto tecnologia musical, como escreveu Cutler, (2004, p. 149):

O que colocou a pilhagem no centro de consumo da arte popular foi uma nova tecnologia que fez com que a pirataria sonora fosse tão fácil que não fazia sentido não fazer. Esse desenvolvimento foi o sampleamento digital, lançado de modo comercialmente acessível pela Ensoniq no meio da década de 1980.

Algumas das obras de John Oswald utilizam samplers, como Dont (1988) e btls (1989). Em btls, o último acorde do álbum Sgt. Pepper's Lonely Hearts Club Band (1967), do grupo The Beatles, é amostrado. Segundo Oswald (2001, p. 4-5):

O sampler original podia armazenar apenas dez segundos de som de alta fidelidade, o que é a razão prática de o primeiro acorde durar dez 
segundos e cada acorde subsequente diminuir em duração, porque os sons reproduzidos desta forma ficam menores conforme aumentam a frequência. Acho que esse encurtamento físico provê uma curva dramática efetiva a essa peça simples.

Curiosamente a capa do referido álbum dos Beatles é uma colagem, onde inúmeras personalidades são retratadas. Sobre o grupo, na mesma entrevista, Oswald comenta: "Por que os Beatles? Bem, eu ainda sou fã, mas o mais importante é que eles proporcionaram, durante sua curta maturidade, uma ponte muito interessante entre a música mais popular do século XX e algumas coisas muito impopulares." (idem, p.11).

Bob Ostertag, após um período de vários anos longe de atividades musicais, período em que trabalhara como ativista e escritor focado em questões políticas na América Central, utilizou um sampler Ensoniq em diversas de suas performances e álbuns, tratando-o como seu instrumento musical (por exemplo, em Attention Span (1990), Sooner or Later (1991), Burns Like Fire (1992), All the Rage (1993), e Twins! (1996)). Ostertag (2009, p.158) sublinha o fato de o equipamento ter controles de pressão e botões que poderiam ser acionados rapidamente com os dedos - características que permitiriam manter uma fisicalidade típica da ação instrumental, e um controle rápido quanto à produção de gestos.

Como mencionado, na década de 1990 os CDs tinham desbancado, de longe, os vinis como meio de circulação de gravações de música. Marcando essa mudança de mídia, John Oswald compôs Plexure (1993), obra na qual procurou representar, em termos de material sonoro, a primeira década da "era do $C D$, tomada de uma perspectiva Europeia-estado-unidense" (OSWALD, 2000, p.14). Fê-lo por meio do emprego de músicas de sucesso comercial lançadas entre 1982 e 1992, com algumas exceções.

Por se tratar de uma mídia digital, o conteúdo de áudio pode ser duplicado sem perda de qualidade. Em uma gravação feita para a mídia, a gravação mestra é virtualmente idêntica às suas cópias ${ }^{32}$. Argumentos similares ao de Tenney, a respeito de sua colagem usando uma gravação de Elvis Presley, são formulados quanto aos discos compactos: a coleção particular de CDs fornece sons com boa qualidade e que podem ser manipulados de modos a manter uma sonoridade interessante ("viva", "consistente" etc.); também fornece sons acessíveis e com qualidade dificilmente conseguida por outro

32 John Oswald comenta sobre a época anterior ao surgimento do CD: "Esse era o tipo de coisa que eu fazia na era pré-digital - procurar boas cópias, não em vinil, de gravações específicas." (Oswald, 2001, p. 37) 
meio (gravação em estúdio e/ou síntese sonora). Mário Del Nunzio (informação verbal ${ }^{33}$ ), comenta, a respeito da utilização de amostras de sons percussivos e de bateria, retirados de diversas fontes (Joey Taffola, Racer X, Judas Priest, Rolf Munkes, Dream Theater, lannis Xenakis, James Dillon, Allain Gaussain, Marc Monnet), em sua obra eletroacústica Improviso em Branco e Preto (Carta às Videntes) (2004):

A falta de intérpretes para tocar música escrita, que eu fazia bastante na época - elas tinham que ficar na gaveta. Então eu me vi na situação de fazer com o material que eu tivesse à disposição. Nesse momento não existe uma razão ideológica para trabalhar com os CDs, era uma questão de possibilidade mesmo, de realização da música. E se eu tinha vontade de trabalhar um material como esse, era muito mais fácil recorrer ao que estava na mão do que lidar com uma outra situação que envolveria a cooptação de pessoas e convencimento, e que me parecia muito mais estressante e menos recompensadora musicalmente.

Mas a tecnologia do CD também falha. Alguns artistas exploraram esses ruídos próprios ao meio do $C D$, não tão transparente assim, afinal, ou, ao menos, não tão transparente o tempo todo / sob todas as circunstâncias. Já em Dab (1989), de John Oswald, ouvem-se sons de falhas de leitura de um aparelho de CD tocando Bad (1987), de Michael Jackson, para adicionar certa instabilidade sonora à música. Essas falhas de leitura foram usadas mais extensamente por Yasunao Tone, na já mencionada obra Solo for Wounded CD (1995). Os CDs de Musica Iconologos (1993) foram preparados usando fita adesiva, de modo que o leitor dos aparelhos de CDs não consiga ler todas as informações, provocando ruídos [glitches], saltos de leitura (a sequência de leitura linear da informação sonora não é obedecida), interrupções e repetições [loops]. O título da peça remete a um evento/performance de Alison Knowles chamado Wounded Furniture [Mobilia Ferida]. Neste, Knowles sugere, entre outras coisas, que performadores colem adesivos e destruam ainda mais uma mobília já em mau estado ${ }^{34}$. Curiosamente, o álbum Jardim das Gambiarras Chinesas (2009), do Duo N-1, contém instruções no próprio encarte para que os portadores do objeto furem o CD (com uma broca de um ou dois milímetros), de modo a provocar efeitos semelhantes aos que Tone realizou em cima dos CDs contendo Musica Iconologos.

Nicolas Collins, em vez de preparar os CDs, procura o mesmo tipo de resultado, modificando o próprio aparelho reprodutor, o tocador de CDs, de modo a poder controlar o 
tipo de ruído resultante (o tipo de erro de leitura do aparelho). Em Broken Light (1992) usa gravações em CD de música para instrumentos de cordas de Corelli, Locatelli e Torelli música de um "'Pasta' Concerti Grossi"35 - junto com um quarteto de cordas que interage com a eletrônica resultante. Com o grupo Impossible Music, Collins continuou experimentos com tocadores de CD, na companhia de David Weinstein, Tim Spelios e Ikue Mori (DAVIES, 1996, p.11).

Por fim, as tecnologias mais disseminadas recentemente: a internet, os formatos de áudio digital comprimidos (a título de exemplo: mp3, ogg, flac), os computadores pessoais, os softwares de edição e manipulação de áudio. Em todas essas tecnologias fica patente a questão do aumento da acessibilidade: a ideia de que uma pessoa possa fazer suas criações musicais de forma individual, com seus próprios equipamentos, sem depender de instituições e corporações, inclusive para a distribuição e circulação de suas músicas. Assim, serão fornecidos alguns exemplos concernentes ao objeto de estudo que se relacionam com essa ideia.

Em uma palestra de $2010^{36}$, Johannes Kreidler comenta o advento das novas tecnologias digitais de transmissão, criação, armazenamento, transformação e compartilhamento de dados. Falando sobre seu disco rígido, contendo 250 gigabytes de arquivos de áudio, "toda a história da música"37, ele retoma o argumento de Finnissy, mencionado no tópico 1.1: antes, com Finnissy, um discurso que dizia "todas as notas foram usadas, tudo já foi composto, por isso a transcrição"; agora, com Kreidler, "todos os sons já foram usados". Então: é realmente necessário programar [sintetizar] uma onda sonora nova [no meu computador], quando eu já tenho milhares de ondas sonoras nessa caixa [seu disco rígido]?. E ainda: como tudo foi já gravado e tocado, não é melhor citar intencionalmente? Ou melhor: há muita coisa, com a tecnologia digital, circulando, as pessoas ouviram muitas coisas, a acessibilidade é enorme, então não há necessidade de reinventar a roda. Se, no documentário Tuning In (MARCONI, 1981), Stockhausen já se referia aos sons instrumentais como ready made sounds [sons encontrados], e ao desejo de compor a vida interna dos sons (através de procedimentos de síntese sonora) ${ }^{38}$,

35 Conforme a partitura, disponível em http://www.nicolascollins.com/texts/brokenlightscore.pdf.

36 KREIDLER, J. Music with Music, palestra de Johannes Kreidler. Internationale Ferienkurse für Neue Musik, Darmstadt, 27 de julho de 2010.

37 Ainda mais se os arquivos estiverem sob algum tipo de compressão para ocupar menos espaço, como o MP3 ou o OGG.

38 "Haviam muitas razões para eu ter investido no som per se; veja, até aí eu havia composto com sons que eram encontrados [sounds that were ready made]. O que eu queria fazer era compor cada som por 
Kreidler, cerca de 30 anos depois, dará a entender que há uma infinidade de sons vivos facilmente disponíveis por aí, esperando para adquirir novos habitant (serem colocados em outros contextos musicais).

Desta forma, Kreidler aponta para um aumento de acessibilidade geral à música de vários tipos e também a grandes quantidades de música, bem como a facilidade de armazenar e utilizar esse material como material composicional, dada a disseminação de computadores pessoais, computadores pessoais portáteis e ferramentas de edição e manipulação do som. Antes era necessário ter acesso a estúdios e objetos físicos nos quais estivessem gravadas as músicas. Agora basta um objeto físico (o disco rígido), que armazena uma quantidade gigante de músicas, e um computador pessoal, capaz de realizar, com softwares, a grande maioria das operações antes realizadas em estúdios de música, não tão acessíveis.

Como resultado da exploração deste característico aumento da acessibilidade a músicas (e a dados em geral), Kreidler (2010) expõe uma máxima, a de que "essa quantidade é uma nova qualidade". Exemplos dessa tendência podem ser tirados da própria obra de Kreidler: Product Placements (2008) utiliza 70.200 fonogramas como material para uma música de apenas 33 segundos; Compression Sound Art (2009) propõe a apresentação de arquivos musicais comprimidos, como a integral das canções dos Beatles tocadas em um décimo de segundo.

A ideia de um aumento de acessibilidade se conecta também com um discurso que articula a volta da figura do músico amador. Os toca-discos e os mixadores disseminam uma musicalidade própria à prática de DJing. Os diversos softwares de criação musical, edição e mixagem de áudio também o fazem: práticas de colagem musical ligadas às noções de remix e mashup tornam-se comuns ${ }^{39}$. Assim, articula-se o estar pronto à mão dos materiais musicais (os arquivos de áudio, na sua maioria, fonogramas de músicas), com o fácil manejo das ferramentas disponíveis (os diversos softwares de criação musical) para reforçar o bordão do faça você mesmo. Possivelmente, apropriar-se de músicas dessa forma rápida e sem muita preparação é uma forma de lidar com o excesso de informação recebida e disponível. A chamada cultura do remix é construída a partir

si só, compor sua vida interna." (Marconi, 1981).

39 Alguns comentários vão nesse sentido. Por exemplo JORDAN \& MILLER (2008, p. 101 e p. 103): “(...) arquivos digitais de uma ampla variedade de materiais gravados estão sendo cortados e manipulados na forma de novas obras de arte - conjugando materiais de fontes distintas e disparates em criações singulares. (...) [essas ações] trazem de volta a ideia de uma cultura popular compartilhada, onde a expressão criativa é essencialmente propriedade da comunidade, e pode ser compartilhada para benefício de todos." 
dessa ideia de acessibilidade. Lawrence Lessig, em uma palestra, parte do documentário RIP: A Remix Manifesto (GAYLOR, 2009), exemplifica:

A importância é que essa técnica [remix] foi agora democratizada. Esse remix dá a qualquer pessoa com acesso a um computador de US $\$ 1.500$ o poder de dizer as coisas diferentemente. Isso é a escrita do século XXI. É alfabetização para uma nova geração. É a construção de uma democracia diferente. É a construção de uma cultura diferente. Na qual o povo participa da criação e da recriação da cultura a nosso redor.

O projeto sCrAmBIEd?HaCkZ! (2006) ${ }^{40}$, de Sven König, apresenta-se como uma tecnologia que facilitaria ao máximo o processo de colagem musical. Segue o texto de apresentação do projeto, escrito em tom debochado característico:

Discos de gramofones, fitas magnéticas, discos de vinil, samplers digitais e computadores já libertaram as amostras há muito tempo. Ainda assim, para que alguém infrinja direitos autorais, é preciso que decida qual amostra realmente quer roubar. É preciso carregar arduamente arquivos de áudio para editores de amostras ou sequenciadores. É necessário cortar, copiar, colar e organizar. Tudo isso demanda uma preciosa energia criativa e muito tempo. Basta disso! Infrações de direitos autorais nunca foram tão fáceis do que com sCrAmBIEd?HaCkZ!

Mas os sonhos de uma democratização fácil do fazer musical também passam pela especulação filosófica sobre a prática dos compositores, os criadores profissionais de música. Harry Lehmann transparece exemplarmente essa tendência, ao tentar antecipar uma tecnologia que permita o manuseio prático de estilos, habilitando práticas de alusão e pastiche, e a programação de gradações entre estas e colagens musicais propriamente ditas:

Algo que mudaria o meio da Nova Música muito mais radicalmente do que
a máquina de composição de Xenakis é uma espécie de kit contendo
material pré-fabricado de Nova Música. Seria concebível para todo
compositor ter inúmeras técnicas composicionais generalizadas para
recorrer ao computador, receber uma ferramenta composicional universal,
com a qual tipos de sons clássicos, românticos, atonais, serialistas,
complexistas, estocásticos ou espectrais podem ser gerados, variados,
combinados, selecionados ou rejeitados. A mudança radical nas artes
visuais causadas pelo software Photoshop ainda há de ocorrer na Nova
Música; mas é certamente uma questão de tempo até um programa
análogo de soundshop ser desenvolvido. (LEHMANN, 2010, p. 6)

40 Disponível em: <http://www.popmodernism.org/scrambledhackz/>. Acesso em: 13 mai. 2012. 
Para terminar o tópico, vale citar um exemplo de técnica recente, já empregada em sCrAmBIEd?HaCkZ!, que se relaciona diretamente com a colagem musical. Trata-se da síntese concatenativa. Métodos que a empregam "usam uma imensa base de fontes sonoras, segmentada em unidades, e um algoritmo de seleção de unidade que encontra as unidades mais compatíveis com o som ou frase musical a ser sintetizada, chamados de alvo. A seleção é feita de acordo com os descritores das unidades." (SCHWARTZ, 2006, p. 3). Entre suas aplicações estariam a síntese sonora instrumental, de texturas e ambiências sonoras, mas também o que ficou conhecido como musaicing ou music mosaicing [mosaico musical]. Nessa prática,

Um som ou frase são tidos como partitura de áudio, e é ressintetizado usando a sequência de unidades que mais combinem com seus descritores, ou seja, com mesmas características de altura, amplitude e/ou timbre. Isso é geralmente referido como mosaico de áudio [audio mosaicing], uma vez que tenta reconstituir uma entidade maior com várias partes pequenas, como nas recentemente populares fotomosaicos. (idem, $4)$.

Por exemplo, as frases compostas de sons percussivos, em ritmos quartenários dançantes, cantadas por König em uma das suas apresentações, servem como alvo para que o computador procure os trechos da música U Can't Touch This (lançada em 1990) de MC Hammer, que melhor reproduzam o que foi cantado; estes trechos então são tocados, junto com os excertos do videoclipe correspondente ${ }^{41}$. Como o processo de procura pelo mais parecido demora algum tempo, König sempre adianta sua cantoria em relação ao que soa, criando frases que se repetem e pontos de encaixe dentro de um pulso e métrica, garantindo assim um fluxo contínuo.

Um exemplo mais obscuro quanto ao resultado sonoro é fornecido por Bob L. Sturm, em sua peça Concatenative Variations of a Passage by Mahler (2005) ${ }^{42}$. Para cada diferente movimento, Sturm usou uma variação do famoso crescendo de percussão da Sinfonia No.2 de Gustav Mahler como alvo, a fim de criar a variação ou ainda de criar o material sonoro a ser trabalhado composicionalmente. Cada movimento serve como estudo de algum aspecto técnico da síntese concatenativa. Lix Tetrax usa material sonoro

41 Aparentemente esse exemplo específico não foi realizado na apresentação de sCrAmBIEd?HaCkZ!, de Sven König na PdCon09, no Museu da Imagem e Som, 26 de julho de 2009. A apresentação no Teatro Sérgio Porto, durante a série "Campos Sonoros" de música contemporânea, organizada porJ.-P. Caron e Paulo Dantas, no dia 05 de agosto do mesmo ano, utilizou principalmente uma canção do grupo AC/DC.

42 A peça consta como "obra em progresso"; não há porém há indícios de novos movimentos, ao menos na página de internet citada pelo autor: <http://www.mat.ucsb.edu/ b.sturm/music/CVM.htm>. Acesso em: 13 mai. 2012. 
da Partita para flauta solo de Bach, tocada por Jean-Pierre Rampal; Highway to Heaven, Starway to Hell, usa Starway to Heaven, do grupo Led Zeppelin e Highway to Hell, do grupo AC/DC (STURM, 2006).

$\mathrm{Na}$ síntese sonora concatenativa há promessas interessantes, ideias que veem a chance de implementação aumentar: partir de uma música $A$, reconstruir outra música $B$, usando fragmentos de $A$. Depois, incorporar fragmentos de $B$, que agora reconstroem $A$; ambos são então usados para imitar um som $C$. Metamorfoseiam-se no som $C$, que agora é multiplicado e granulado, seus grãos assumindo formas que aludem a $\mathrm{A}$ e $\mathrm{B}$ etc. $\mathrm{Ou}$ seja, passagens da síntese sonora para o sampleamento, da falta de relações de proximidade entre A, B e C, para relações de alusão e citação entre eles. 


\section{Capítulo 2: Categorias}

Este capítulo apresentará noções e termos caros à pesquisa: música eletrônica, música experimental, colagem musical, sampleamento, plunderphonics, citação, arranjo, plágio, intermusicalidade. Os três primeiros termos referem-se ao escopo da pesquisa; destes, os dois primeiros são primeiro abordados separadamente, de modo a melhor aproveitar as informações contidas na literatura encontrada (que ora se referia a um ou a outro, mas raramente a ambos em conjunção ${ }^{43}$ ); posteriormente, são conjugados, de modo a chegar a uma circunscrição do que seria a música eletrônica experimental, no que concerne essa pesquisa.

Sampleamento e o plunderphonics são apresentados, nas suas relações com os tipos de procedimento que implicam e objetos e abordagens que favorecem. Procura-se também estipular diferenças entre formas de citação e colagem musical, bem como de arranjo e plágio. Termina com um termo abrangente, uma espécie de norte da pesquisa, amplo o suficiente para acolher a variedade existente: a intermusicalidade.

Essa apresentação por categorias pretende ser um exercício em definição e circunscrição de termos, a partir da bibliografia pesquisada. As dificuldades encontradas tornam explícitos os limites conceituais envolvidos: os limiares tornam-se ora muito difusos, ora muito rígidos, quando aplicados às músicas e práticas musicais existentes. Contra essa rigidez já alertara Wittgenstein (2008, p.49):

\footnotetext{
A ideia de que para tornar claro o sentido de um termo geral era necessário descobrir o elemento comum a todas as suas aplicações, estorvou a investigação filosófica, não só porque não conduziu a nenhum resultado, mas também porque levou a que os filósofos rejeitassem como irrelevantes os casos concretos, os únicos que poderiam tê-los ajudado a compreenderem o uso do termo geral.
}

Esta empreitada, portanto, serve como uma primeira tentativa de esclarecer determinadas utilizações dos termos e propor que certos usos ou concepções sejam favorecidos, em detrimento de outros, contribuindo assim para o estabelecimento de uma terminologia mais consistente ou, ao menos, de um uso mais consciente dos termos das implicações, desvios e contradições que eles mesmos envolvem. É preciso reconhecer e perscrutar quando

43 Com a exceção de Demers (2010). 
Somos claramente incapazes de circunscrever os conceitos que utilizamos; não porque desconhecemos a sua verdadeira definição, mas porque não existe qualquer definição verdadeira desses conceitos. Supor a sua necessidade seria como supor que, sempre que as crianças brincam com uma bola, jogam um jogo de acordo com regras rigorosas. (idem, p. $57)$.

\subsection{Música Eletrônica}

Considerar-se-á música eletrônica, aqui, qualquer tipo de música em que se utilizem principalmente - se não exclusivamente - instrumentos e equipamentos eletrônicos ${ }^{44}$.

Principalmente denota, de modo bastante genérico, uma prioridade forte. Músicas que priorizam uso de instrumentos não-eletrônicos não pertencem a essa categoria. Ficam no entanto duas questões que, dado o caráter genérico da definição estipulada, também permanecem, como suas respostas, no campo da generalidade. A primeira diz respeito à utilização de equipamentos eletrônicos, cada vez mais generalizada, em todos os segmentos da produção musical. Esses equipamentos integram cada vez mais a produção musical hodierna, a ponto de ouvirmos grande parte de nosso repertório musical através de caixas de som, na forma de reproduções de música. Essas reproduções são viabilizadas pelos processos de fonografia, que envolvem utilização de equipamentos eletrônicos para gravação, mixagem e masterização. Seguindo o que foi definido é preciso, então, considerar que estes processos são frequentemente secundários do ponto de vista de uma concepção do musical (e da musicalidade). Assim, nesses casos, a música não é a sua gravação, isto é, gravações de música não-eletrônica continuam sendo gravações de música, e não deverão ser confundidas conceitualmente com as músicas em $\mathrm{si}^{45}$. O que implica que o termo Música Eletrônica verse sobre o conteúdo musical. Quando os processos de fonografia não são determinantes para a constituição desse conteúdo não devem ser tratados como partes deste, ao menos no que concerne a categorização utilizada aqui.

A segunda questão se refere aos processos de amplificação, microfonação e

44 A definição de Joel Chadabe $(1997$, p. x) é similar, mas omite a referência à primazia do uso de equipamentos eletrônicos. A definição de Demers (2010, p.5) está em acordo.

45 Mesmo que a música coincida com a gravação da música, em termos de apresentação, isto é, que ela seja um artefato cultural fixado em suporte. 
transformação de fontes sonoras diversas. O raciocínio é similar: é preciso que esses processos transformem o estatuto da fonte sonora, de modo a poder ser considerada uma fonte sonora eletrônica, ou que os próprios equipamentos utilizados sejam considerados viabilizadores da musicalidade, em relação a uma fonte sonora - e, portanto, sejam considerados como parte da fonte sonora. Uma guitarra nesse sentido pode, dependendo do contexto, ser considerada um instrumento eletrônico, embora na grande maioria dos casos não o seja (quando toca acordes ela apenas expande um contexto acústico/mecânico). Um microfone e um amplificador são equipamentos eletrônicos determinantes quando se quer musicalizar um som quase inaudível - som que não seria musical se não estivesse muito amplificado.

O termo utilizado nos Estados Unidos, Experimental Music [Música Experimental], designa o que, em outras regiões, é chamado música eletroacústica (LANDY, 2007, p.11). Aqui, música eletrônica engloba mais manifestações musicais. Toma-se simplificadamente o termo música eletrônica como organizado em torno da produção de música eletroacústica, eletrônica e algumas formas de música experimental. Estas partilham uma grande importância atribuída ao uso de instrumentos eletrônicos, de processos de fonografia e técnicas de processamento de sinal de áudio.

O termo música eletrônica foi utilizado em alemão - elektronische Musik -, na década de 1950, pelos compositores do estúdio de Colônia para definir a música que produziam. Herbert Eimert (apud PALOMBINI, 1998), responsável pelo estúdio, escreveu na época:

O fato de se poder criar neste sistema uma nova matéria musical impossível de obter-se com os instrumentos clássicos constitui um verdadeiro critério da música eletrônica. Poder-se-ia dizer (...) que a música eletrônica começa onde cessa a música instrumental.

Essas novas possibilidades que dariam figura a uma nova música - vislumbrada anteriormente, mas só agora possível de implementação e desenvolvimento - estiveram ligadas a alguns potenciais próprios desse meio de produção. Se levado a sério esse pequeno relato inicial, poder-se-ia pensar a música eletrônica como ligada à extrapolação de limites de precisão mecânicos; à supressão da necessidade da manutenção de relações gestuais e de causalidade mecânica, quanto à produção de som; à possibilidade de trabalhar com sons em estado aprisionado - a fonografia. Essas três características estão presentes em inúmeros exemplos de obras abordados nesse estudo. 
As chamadas músicas eletrônicas mistas ou eletroacústica mistas, que combinam instrumentos acústicos com o uso de eletrônica, ficam assim excluídas deste escopo por não figurarem a eletrônica como principal e, portanto, cumprirem apenas parcialmente as exigências impostas. Exemplos são Broken Light (1992), de Nicolas Collins, por ter um quarteto de cordas na sua formação, bem como Living Inside a Box (2010), para pequeno grupo instrumental (piano, percussão, cordas, metais, sopros), sampler e vídeo (opcional), de Johannes Kreidler.

Outro exemplo que falha em pertencer à categoria de música eletrônica é a série de álbuns que Weasel Walter gravou a partir de 2006, Weasel Walter Plays Over Records [Weasel Walter Toca Por Cima de Gravações] ${ }^{46}$. Nela Walter toca bateria junto com (ou por cima de) gravações de jazz e de música contemporânea. $O$ processo é bastante simples: é colocado um álbum específico para tocar em algum aparelho e junto é tocado um improviso, à bateria, que procura interagir musicalmente com a gravação. O diálogo com os músicos 'surdos', porque fixos, que figuram nas gravações, é possível apenas unilateralmente ou, usando a imaginação, apenas parcialmente: é necessário desconhecer o conteúdo dos álbuns utilizados para pensar que a interação possa ter alguma espontaneidade pelo lado das gravações; gravações essas que respondem aos gestos de Walter. Os álbuns eram distribuídos na internet pelo software de compartilhamento de arquivos Soulseek ${ }^{47}$ (MASEN, 2008). Dois deles são: John Coltrane (featuring Weasel Walter) - Ascension (no texto consta: gravado em 28 de junho de 1965; sobreposição da bateria gravada em 26 de janeiro de 2006, nonwave \#24) e lannis Xenakis (feat. Weasel Walter) - Music for Strings (sobreposição da bateria gravada em 12 de junho de 2007, nonwave \#65).

Esse processo é similar ao realizado pela música eletrônica de John Oswald, Dont (1988). Oswald resolveu trocar a banda de acompanhamento da música Don't, interpretada por Elvis Presley e gravada originalmente em 1957. Para tal, produziu algumas versões levemente diferentes da canção a partir da gravação original. Em seguida convidou músicos para gravar individualmente suas partes de acompanhamento, cada um a partir de uma das versões realizadas. Pediu também que gravassem várias vezes suas partes de acompanhamento, de modo que Oswald, ao final, pôde sobrepô-las todas, adicionando uma versão final da faixa feita a partir de Don't, além de alguns

46 Até 2008 eram 75 dessas gravações lançadas com a seguinte informação: nonwave production - weasel walter playing over records.

47 Vide <http://www.slsknet.org/>. Acesso em: 29 mai. 2012. 
acréscimos extras ${ }^{48}$. O resultado final é permeado por uma espécie de surdez complexa. A música é eletrônica, pois coloca a fonografia (e portanto toda a eletrônica envolvida) como foco principal da obra.

O processo, segundo Oswald (2001, p. 21), procurou fazer referência a duas práticas da gravação: a primeira, a "parede de som" [wall of sound], procedimento utilizado extensivamente por Phil Spector no começo dos anos 1960, que consistia em "engrossar o som" das gravações produzidas. Isso envolvia multiplicar as partes instrumentais nas gravações, isto é, gravar várias vezes a mesma parte - criando um efeito de orquestra. A segunda, a superposição de novos sons a uma gravação já realizada, o chamado overdub, também realizado por Weasel Walter. A ideia de Oswald é de não apenas tornar uma canção conhecida de Elvis Presley em algo estranho e novo, mas fazê-lo utilizando técnicas comuns e presentes em grande parte das gravações comerciais de música pop. Mostra assim outras possibilidades de uso e radicaliza características dessas práticas. No caso da "parede de som" pode-se pensar no efeito de perda de definição do som, ocasionado pela sobreposição de várias linhas sonoras levemente diferentes, como algo de interesse musical, sujeito a variação, e a tratamento criativo; ou ainda, como produzir tal efeito de densificação do som com um músico que improvisou sua parte, e como isso geraria desvios maiores entre as diversas tentativas de tocar aquela mesma parte.

No caso das superposições realizada em multicanais, de modo extensivo, fica patente uma surdez latente: o músico que está a tocar/gravar só ouve o fonograma que Ihe foi fornecido. A todo o resto ele permanece alheio e surdo: possíveis músicos que já gravaram ou que ainda irão contribuir, práticas de edição e mixagem que venham a ser feitas. Ademais, como não é necessária a presença física dos músicos que não estão a gravar, também não é necessária a possibilidade dessa presença física. Ou seja, basta que exista um fonograma que contenha a performance daquele músico. Por isso Elvis Presley, falecido 1977, pôde integrar uma gravação realizada dez anos depois; por isso John Coltrane, falecido em 1967, pôde integrar uma gravação realizada quase 40 anos depois.

48 A versão contida no EP Plunderphonics (1988) contém colagens musicais derivadas de Cecil Taylor e György Ligeti (OSWALD, 2001, p.21), enquanto outra, a contida na compilação Plunderphonics 69/96 (2001) não as contêm. 


\subsection{Música Experimental}

Música experimental é entendida aqui como categoria que engloba uma série de manifestações musicais, da música eletroacústica à produção eletrônica alternativa, incluindo manifestações ordenadas sob nomes como glitch [ruído], improvisação livre, noise [barulho], microsound [microssom], arte sonora ${ }^{49}$.

O termo experimental, ligado à prática musical, foi utilizado por John Cage, que publicou um artigo denominado Experimental Music: Doctrine, em 1955, no qual refere-se ao experimental como uma ação "na qual o resultado não é previsível" (CAGE, 1970, p. 13). Segundo Cage (idem, p. 15):

Uma ação experimental, gerada por uma mente tão vazia quanto estava antes de se tornar uma, e então em acordo com a possibilidade do que quer que seja, é por outro lado, prática. Não se move em termos de aproximações e erros, como uma ação 'informada' pela natureza precisa mover-se, pois não foram criadas imagens mentais a priori; vê as coisas como elas são, diretamente: envolvidas impermanentemente em um jogo infinito de interpretações.

As peças de Cage buscam essa qualificação quanto à intenção composicional. A partir das práticas dele e de outros compositores americanos (que priorizavam concepções musicais envolvendo processo, indeterminação, acaso e maior liberdade de interpretação), Michael Nyman, em seu livro Experimental Music: Cage and Beyond (publicado em 1974) 50 $^{0}$ definiu a música experimental em contraposição à vanguarda europeia, extrapolando características de ambas através da análise de diferenças de procedimento, concepção e abordagem. A vanguarda europeia, segundo ele, priorizava o controle sobre o material composicional, a utilização de técnicas combinatórias e a criação de obras com identidades claras quanto ao resultado sonoro. Paralelamente, a música experimental é vista como um campo musical de intensa experimentação formal não-institucional, contrapondo-se à música contemporânea de concerto, debitária das vanguardas musicais institucionais do pós-guerra. Em desacordo com essa visão, e atualizando a questão, Demers aponta (2010, p. 141):

49 Essa concepção é corrente, aparecendo, por exemplo, em Myatt (2008, p.1), no editorial da revista Organized Sound.

50 Nyman (1992). 
Hoje em dia o experimentalismo é sinônimo de vanguarda porque ambos impulsos alegam independência da cultura de massa e do consumismo, assim como ambos alegam superioridade com base na dificuldade de suas produções e no prestígio institucional que detêm. ${ }^{51}$

Ao mesmo tempo, a comunidade experimental diluiria as barreiras entre o erudito e o popular; lazzetta (2009, p. 200) assim comenta:

Se as comunidades digitais que atuam no âmbito experimental não eliminam essas barreiras [entre o erudito e o popular], ao menos apontam para sua anacronia ao se lançarem num território que não pode ser necessariamente associado nem ao erudito (pela ausência de comprometimento com as tradições históricas da música e de filiação institucional), nem ao popular (especialmente por sua falta de inclinação à difusão comercial de sua produção e pela inexistência de um projeto de penetração numa cultura de massa, ou mesmo entre grupos não especializados).

Pierre Schaeffer também utilizou o termo, já em 1953, quando escreveu Vers une musique expérimentale (PALOMBINI, 1998), com o objetivo de reunir sob a bandeira da música experimental abordagens absolutamente distintas usando materiais concretos. Essas abordagens foram apresentadas na Primeira Jornada Internacional de Música Experimental, no mesmo ano. Posteriormente o termo foi também utilizado para reunir abordagens distintas agrupadas sob os termos musique concrète, elektronische musik, music for tape e as músicas exóticas (PALOMBINI, 1998). Segundo Gayou (2007, p. 207) Schaeffer passou, a partir de 1971, a se referir à produção, antes denominada por ele música concreta, como música experimental, desta vez sem a conotação sincrética anterior, mas com a intenção anunciada de reforçar que tratava-se de uma pesquisa musical, que se desenvolvia através de experimentos. Esses experimentos visavam à descoberta de uma nova musicalidade e o desenvolvimento dos potenciais musicais contidos nos diversos objetos sonoros formulados.

Demers (2010, p.141), em seu livro Listening Through the Noise: The Aesthetics of Experimental Electronic Music, circunscreve o termo: experimental implicaria a criação de algo novo, em vez do aperfeiçoamento de práticas antigas; as manifestações caracterizadas como música experimental necessariamente passariam por uma fase em que suas práticas desafiariam as convenções estabelecidas do que é o musical.

51 Autores como Fabbrini (2005), ao tratarem das artes visuais e movimentos artísticos ligados a estas (como a performance), ligam o termo vanguarda à existência de um impulso utópico; deste ponto de vista, ficaria a questão de determinar se essas vanguardas utópicas existiram de fato, em se tratando de música. 
Seguindo essa argumentação, pode-se pensar a música experimental como uma prática que prioriza a criação de novas concepções do musical, pautadas na experimentação formal. Os músicos praticantes são incentivados a conceber música de um modo altamente pessoal e tentar criar rupturas com os discursos musicais estabelecidos. Como advogaria a criação de novas formas de fazer, a música experimental seria transversal aos vários gêneros ${ }^{52}$ musicais, podendo servir-se de características e restrições convencionadas destes, mas não se fixando em nenhum, esquivando-se assim de configurações mais codificadas. Nesse sentido, sinteticamente, poder-se-ia pensar a música experimental como um antigênero. Ficaria também assim impressa a vontade de não fixação desses modos como códigos.

Como mencionado no primeiro parágrafo deste tópico, é inegável que o termo passou a abarcar uma série de práticas que, embora possam ter-se originado na busca de novas formas e maneiras de se fazer e conceber música, conformaram-se como gênero, com características convencionadas e organizadas. A Música experimental teria de ser então estruturada como algo acima da noção de gênero (um metagênero), e que abarcaria também a tradição e história das configurações dos gêneros ligados àquele primeiro impulso de criação a partir de estruturas não codificadas, de ruptura com as convenções e códigos estabelecidos. Sobretudo teria de abarcar a história de sua constituição enquanto termo, a fim de evitar que toda a história da música seja repensada como uma história da música experimental.

Não há aqui espaço para a análise dessa possibilidade, ficando portanto apenas como tese. Incorporo a problemática da determinação do termo música experimental como característica própria deste.

\subsection{Música Eletrônica Experimental}

A existência de uma grande intersecção entre música experimental e música eletrônica pode ser explicada historicamente. Quanto à terminologia, parte-se de Pierre Schaeffer e John Cage, como comentado nos tópicos acima. Ademais, a ideia de que novos meios criariam novas formas de expressão, no caso da música, esteve desde cedo

52 A fim de não complicar e nem aprofundar demasiadamente essa discussão, utilizo aqui uma acepção de gênero mais estática e fixa, das muitas que John Frow (2006, p.10) fornece, em seu livro introdutório à questão dos gêneros na crítica literária: "podemos dizer que gênero é uma série de restrições convencionadas e altamente organizadas para a produção e interpretação do significado." 
associada ao surgimento de equipamentos e instrumentos elétricos e eletrônicos; natural que uma identificação dessas possíveis novas formas de expressão musical como de caráter experimental fosse feita.

Comentários nesse sentido são encontrados em declarações de 1916 de Edgar Varèse (2004, p. 21, nota 1): "nas minhas próprias obras eu sempre senti a necessidade de novos meios de expressão"; e em 1922: "O compositor e o eletricista terão de trabalhar conjuntamente para alcançar isso". Na mesma linha de raciocínio, em 1937, John Cage (1970, p. 3-4) escreveu a esse respeito: "Eu acredito que o uso de ruídos para fazer música irá continuar e aumentar até que cheguemos a uma música produzida com a ajuda de instrumentos elétricos, que irão tornar acessíveis, para fins musicais, qualquer e todo som audível".

Essas novas formas de expressão e de realização musical estariam guiadas, em grande parte, por necessidades criadas a partir de questionamentos estéticos e culturais por parte dos músicos, como fica patente nos casos de Cage e Varése, mas também de Luigi Russolo (2004, p. 10-14), célebre por seu texto Arte de Ruídos (de 1913). Não obstante, segundo Fernando lazzetta (2009, p. 23), as próprias possibilidades oferecidas pelas tecnologias teriam papel não tão proeminente nessa exploração; elas antes canalizariam desejos já existentes e apontariam para soluções de problemas já levantados. A este respeito escreve:

A Elektronische Musik alemã pode ser tomada como exemplo da exploração de novas tecnologias musicais em função de interesses estéticos. No início da década de 1950, os compositores do estúdio de Colônia viram nos geradores e processadores de sons disponíveis uma solução para problemas suscitados pelas técnicas de serialismo integral que se desenvolviam naquele momento. (idem)

Isso não implica a determinação de que os projetos composicionais tenham sempre prioridade em relação aos desenvolvimentos tecnológicos, mas aponta para os dois polos da relação: a tecnologia tomada instrumentalmente (para a solução de problemas já formulados); e a tecnologia tomada como campo exploratório (cujas possibilidades levariam à criação e exploração de novos problemas).

A música eletroacústica, tradicionalmente institucional e ligada à tradição da música de concerto, é por vezes também abrigada dentro da categoria da música eletrônica experimental, pela sua ligação à ideia de experimentação, de exploração formal, mas também pela vinculação de vários artistas a ambas as práticas, tomadas separadamente: 
da música eletroacústica e da música experimental. Essa constatação aponta para um uso duplo do termo, tanto como um guarda-chuva, que abriga diversas formas de atuação musical, quanto como algo que, sem exatamente se contrapor, se diferencia da música eletroacústica. Neste trabalho vale o primeiro uso do termo, já que aponta para uma convergência entre ambos, que me é prática.

A maior parte das músicas ouvidas hoje em dia são gravações; a maior parte delas, entretanto, não tem vínculos com o que chamamos de música experimental. Tentativas relevantes de aproximar fonografia e experimentação - e música eletrônica experimentalsão justamente objeto desse estudo: as diferentes colagens musicais.

Ademais, muitos gêneros eletrônicos, incluindo a música eletrônica de pista (e suas inúmeras vertentes, como o mashup e a sampladelia) e o rap, não são enquadrados na categoria estipulada. O mashup lida extensivamente com práticas de colagem musical. Não pode, no entanto, ser classificado como um gênero eletrônico experimental, dado que pertence à tradição da música eletrônica de pista/dançante, cuja intenção está ligada a valores de entretenimento, que tradicionalmente não prioriza a exploração formal. A construção das misturas [mashups] é realizada muito fortemente a partir de convenções da música pop e do rap, e do tipo de prática de amostragem sonora do remix, ligado à música eletrônica de pista.

$\mathrm{Na}$ literatura, alguns artistas ligados a esse gênero são mencionados, dos quais dois serão citados. Thomas Bey William Bailey (2009, p. 94-5), ao defender práticas musicais mais extremas, experimentais e radicais, critica Danger Mouse, um representante do mashup. Suas produções seriam uma diluição das técnicas da colagem, em prol de uma atitude acrítica e de uma música de entretenimento, muito próxima ao que o autor identifica negativamente como "música da indústria corporativa" e que mais reforçam o culto e celebração de mega-estrelas da indústria musical do que expõem o caráter artificial e publicitário desses artistas. Bailey parece incluir a consideração sobre o gênero mashup apenas para apontar como artistas e grupos mais radicais, como Negativland, são mais consistentes. Essa diluição seria a utilização de procedimentos de colagem musical dentro de uma estética hedonista que se conforma a padrões comercialmente bem estabelecidos do agradável, do ornamental, do superficial, do apaziguado e do bem feito. O Grey Album (2004) ${ }^{53}$ [Álbum Cinza] seria um remix bem sucedido do Black Album (2003) [Álbum Preto], de Jay-Z, usando como material excertos

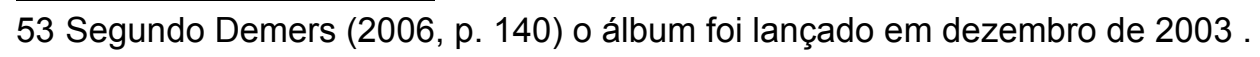


do chamado White Album (1968) [Álbum Branco], dos Beatles: algo bem feito e bonito dentro de padrões musicais bem estabelecidos, engraçado e humorado, mas que não conteria nenhuma mensagem artística mais profunda. As colagens musicais, nas músicas de Danger Mouse, seriam apenas mais um produto feito por um artista, com a diferença de que seu material musical advém de outras músicas. Ou seja, seguindo a avaliação de Bailey, haveria modos que extirpariam das colagens certos potenciais de resistência, de incentivo à reflexão sobre seus objetos - a música e a escuta. $O$ olhar de desdém quanto à mercadoria se perderia, e os signos e a escuta não seriam deslocados de seu local habitual, isto é, postos em movimento, em reflexão.

Caberia como mérito a Danger Mouse, no Grey álbum, o fato de ser um popularizador do gênero mashup, marginalizado devido aos problemas legais que enfrenta (referentes à suposta infração de leis de propriedade intelectual). Pelo fato do álbum ser popular e ter sido tirado de circulação após o artista receber uma carta da EMI, empresa detentora dos direitos dos Beatles, o Grey Album pôde também ser utilizado como um símbolo importante da necessidade de revisão e mudança das leis de direitos autorais e propriedade intelectual vigentes. Protestos contra a ação da EMI foram realizados, por exemplo, por McLeod e Battle (DEMERS, 2006, p. 104). Esse mérito não seria, entretanto, derivado da música, mas da situação social envolvida. É de se perguntar também se o caráter de remix bem executado do álbum não tende a ser interpretado pelo ouvinte como algo que reforça a diferença entre um trabalho profissional (do artista Danger Mouse) e um amador (de alguém que só brinca de mashup). Se esse for o caso, corre-se o risco também de considerar a disputa legal em torno do álbum como meramente um caso especial, em que deveriam permitir ao artista uma licença, ou seja, recair numa discussão superficial que não favoreceria a comunidade de praticantes como um todo, mas apenas os artistas eleitos, os profissionais detentores da permissão para praticar.

O segundo exemplo é Girl Talk. Conforme mencionado, o artista radicaliza procedimentos do mashup, de modo a misturar inúmeras amostras de música em cada mistura. All Day (2010), por exemplo, utiliza 374 músicas como fornecedoras de material para a obra, que segue ininterruptamente por aproximadamente 71 minutos $^{54}$. Durante toda a peça, porém, depondo contra a ideia de que possa ser considerada experimental, há sempre a manutenção de uma fórmula: manter um ritmo dançante, sobrepor rifes e

54 Segundo lista fornecida pelo artista em seu website (GILLIS, Sem data). 
refrões de sucessos musicais (das décadas de 1970 até o presente) a vocais de canções rap de sucesso, geralmente do estilo gângster. A filiação declarada do artista também reforça essa classificação: sua intenção de criar colagens pop e música de festa. Segundo Joanna Demers (2010, p. 57-9), Girl Talk teria o mérito de

zombar de convenções não declaradas que ditam a relação entre música e raça. (...) Forçar o gangsta rap [rap dos gangsteres] a tocar harmoniosamente [nicely] com o rock progressivo é um ato de transgressão, não apenas racial mas também de gênero. Qual Girl Talk o faz, o sampleamento age como um ato de violência não natural contra convenções genéricas.

A escuta de All Day envolve certa anestesia: as diversas colagens passam incessantemente em um ritmo de festa e celebração, como se não houvesse tempo para a nostalgia que as colagens normalmente evocam. Gregg Gillis (o responsável por Girl Talk) apresenta uma visão que o presente da música pop teria de sua história, de suas conquistas. Este panteão do pop: seu brilho é apresentado como sua condição de animador da vida cotidiana - ostentação através de sorrisos e danças. Nesse sentido, tal qual a concepção de Bernd Alois Zimmermann sobre um tempo circular que prepararia uma superação do tempo fenomenal, rumo a um tempo da experiência subconsciente, da coexistência de tempos, Gillis acaba por formular uma versão pop a partir de uma cultura de massas e seus produtos, e de como ficam impregnados nas pessoas; uma circularidade temporal realista, no sentido atribuído por Lyotard (1992): eficiente, eclética e niveladora das diferenças.

As palavras e exclamações usadas ou corroboram o clima hedonista da música, ou são por ele alienadas. Com a manutenção desse fluxo musical alegre e dançante, parece não importar se o que se diz é ofensivo, escatológico, grosseiro, nem que um trecho de uma mega-estrela da indústria como Rihanna seja colocado junto a um acompanhamento de uma banda anti-indústria como Fugazi. O trabalho de Girl Talk tem essa qualidade: mostrar como as colagens são um modelo plausível para a prática criativa de boa parte da música pop hodierna, desconstruindo a figura do artista como um indivíduo especial e único, detentor de uma mensagem:

A música pop e/ou de outros gêneros parecem intocáveis. (...) Obviamente eles criam isso, forçam essa ideia em sua mente: [de que] essas pessoas são superestrelas, [de que] são intocáveis. Então só de poder manipular isso e fazer o que você quiser, sabe... (GILLIS, apud GAYLOR, 2009) 
E mais: tornar evidente o papel essencial que a familiaridade com uma música exerce sobre a construção de uma escuta de música pop, sobre o sentimento de comunidade temporária e celebrativa que esta envolve.

Voltando à caracterização da música eletrônica experimental, retoma-se a formulação de Joanna Demers, que apresenta dois pontos de interesse: na música eletrônica experimental parece haver uma espécie de repúdio à cultura de massa, ou ao menos um afastamento e a incapacidade de integração aos mecanismos desta cultura; isso vai de acordo tanto com a postura crítica em relação ao material musical e às tecnologias utilizadas, de boa parte dos exemplos aqui abordados, bem como a pouca penetração destes em um âmbito da cultura de massas, da mídia de massas, dos grandes eventos e das grandes corporações. Há também, na música eletrônica experimental, segundo Demers (2010, p. 172), a dissolução dos limites musicais, do que ela chama de "enquadramento musical" [musical frame]: características que permitam separar a música do mundo, que permitam prontamente identificar algo como música. Esse enquadramento musical favorece a construção da "obra musical autônoma", já que aponta para pressupostos de separação entre música e vida. Uma vez que as zonas de confusão entre música e vida se multiplicam, isto é, quando o enquadramento deixa de ser opaco, cabe cada vez mais aos ouvintes, por um ato de vontade e/ou disponibilidade, acatar ou reenquadrar algo como musical. Essa dissolução ocorreria por uma série de fatores, incluindo a criação de momentos de confusão quanto à distinção entre som produzido ao vivo e som pré-gravado; a incorporação de todo tipo de som não-musical (do mundo) como material; a utilização de espaços não convencionais e não tradicionais para as apresentações; o não estabelecimento de formas musicais claras, em que uma estrutura musical possa ser facilmente apreendida.

A música eletrônica experimental encorajaria então um modo de escuta, denominado pela autora de "escuta estética" [aesthetic listening], na qual o ouvinte atenta intermitentemente tanto aos sons em si (suas qualidades sonoras) quanto a outros estímulos - notadamente, seu valor informacional -, reconhecendo características estéticas desses sons.

(...) Assim, a escuta estética também inclui a experiência da apreciação das características de sons não-musicais como objetos estéticos. Isso não exclui identificar a causa ou as associações externas ligadas à fonte de um som (...). Um dos objetivos de Cage era habilitar os ouvintes para que eles escutassem todos os sons como se estes fossem música. (...) Mas a 
música eletrônica experimental não meramente demonstrou que a música expandiu ou deva expandir seus limites mas também que a escuta musical constitui apenas um tipo bem limitado de experiência estética da escuta. $E$ enquanto especialistas insistem quanto às distinções entre os vários metagêneros e gêneros, não especialistas podem muito bem perceber na música eletrônica [experimental] como um todo, não apenas uma nova experiência musical, mas um novo meio no qual o som é estético mas não especialmente musical. (DEMERS, 2010, p. 152-3)

Embora seja possível concordar com o diagnóstico da autora, ele depende de um uso da palavra música que é, no mínimo, confuso. Primeiro porque a música (eletrônica experimental) seria algo que apontaria para a não-música. Nessa concepção, o uso nominal do termo seria resultado apenas do resquício de um uso que antes estava mais de acordo com o conceito música, mas que cada vez menos está. No entanto, isto prevê um conceito de música que não é capaz de absorver uma série de inovações e práticas que são efetivamente tratadas como música hoje em dia. Se a música é uma forma artística, então deve ser autoproblematizante: os artistas estão frequentemente explorando os limites do que seria música, mas esses limites não são fixos; essa exploração leva a uma expansão tanto do que é música, quanto da possibilidade de atribuir o nome música a várias manifestações. Um conceito artificial e fixo de música fatalmente cairia numa concepção que extirparia da música seu lado mais notadamente artístico (problematizante e exploratório). É possível que se chegue de fato nos limites do musical, e que sejam intransponíveis, mas não é o que ocorre com a música eletrônica experimental, uma vez que os músicos desse âmbito chamam o que fazem de música, e continuam a produzir obras e performances, ou seja: artefatos que têm características próprias e que não facilmente se diluem na existência humana cotidiana. A proposta de Cage, entre outras, expande o alcance do conceito de obra musical, mas a custo de mantê-lo. A música não apenas pode incluir características retiradas do mundo como sempre o fez. O fato de isso parecer se acentuar com as práticas experimentais não implica em uma negação da musicalidade, mas sim que uma determinada noção de musicalidade, estreita demais, não é a única operante; que há outras musicalidades e outras possibilidades para a música.

Dito isso, a noção de enquadramento musical não precisa ser descartada. Ela apenas não versa sobre o que é propriamente musical ou o que é sonoramente claramente não-mundano, ou sobre o que indicaria a autonomia em se tratando de música. Versa, no entanto, sobre a aparência do musical, de como ela pode forjar 
separações para com o mundo, de como cria condições de autonomização. Se a nota musical representa essa aparência, na sua máxima força, então ela é um dos principais elementos desse enquadramento. Entretanto, tudo o que já estiver bem estabelecido como música fortalecerá uma noção de enquadramento musical, além da nota: o trabalho motívico, a melodia, o ritmo repetitivo e baseado em um pulso, a quadratura, a forma canção, e tudo o mais que foi aprendido como música (porque foi explicado: isso é música). Isto é, o enquadramento musical será tudo aquilo que está bem codificado dentro de uma prática musical. Essa definição é, entretanto, cultural e portanto contextual. Mas como há visões dominantes de mundo e visões historicamente consagradas, também há histórias da musicalidade, com seus enquadramentos próprios, com aparências específicas de música. Há vários empregos da palavra música, e nem por isso todos concordam ou podem ser subsumidos sob um único conceito bem definido de música. Admitir o enquadramento musical, em vez de um enquadramento musical é, portanto, admitir uma conceitualização dominante do que é música. No caso de Demers, justamente tudo aquilo que a música eletrônica experimental parece estar distante. Isso tem sua razão de ser, mas apenas a partir de um esquema hegeliano, teleológico, que ecoa para o campo musical os discursos de fim da arte ${ }^{55}$. No entanto, nesse caso específico, corre-se o risco assim de se perder o contato com a realidade, com as práticas que estão a acontecer, práticas de música. Também corre-se o risco de reforçar uma concepção de música próxima daquela justamente pertencente à cultura de massas: uma prática que, embora não reivindique autonomia, se apoia numa clara separação de música e mundo, e que, a fim de garantir uma familiaridade máxima, se utiliza quase que apenas de formas de fazer música já codificadas e bem estabelecidas. Se as músicas populares favorecem escutas estéticas, desatentas, intermitentes, fazem-no sob o fundo de uma concepção hipotética maximamente compartilhada do que é o musical.

Ou seja, a menos que joguemos com palavras e conceitos, dificilmente a música experimental é o fim da música. Mais vale contar que, para as colagens musicais, dentro da música eletrônica experimental, há um impulso de desconstrução. De usar uma música fora de seu ambiente, de sua moldura, de tornar evidentes certas molduras, algumas aparentemente bastante robustas e concretas, outras feitas de materiais evanescentes. Se o rei está nu, ele se apresenta como estando nu, mesmo que tenha decretado estar vestido.

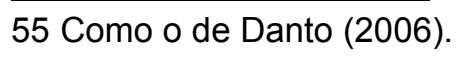


Masami Akita - conhecido por seu nome artístico: Merzbow -, ao ser entrevistado, aponta para o fato de que, ao final da década de 1990, o gênero noise passou a ser encarado como música, isto é, que a concepção de musicalidade tinha passado a incorporar práticas do gênero tidas anteriormente como antimusicais.

Quando primeiro comecei, eu queria definitivamente fazer uma música que fosse tão odiosa para os ouvidos que não poderia ser aceita como música. Mas agora, quando ouço atentamente à música que fiz à época, não era tão dura para se ouvir, devo admitir. Naqueles dias, noise não era considerado música. É por isso que quis introduzi-lo a uma audiência muito mais ampla. E para dá-los um gosto de música [a taste of music] que vai contra o que é convencional [conventional grain]. Acho que é um método muito efetivo. Mas de acordo com noções musicais atuais noise é considerado música. Agora que noise [ruído] e música não são mais polarizados, noise se tornou muito mais puro em forma. Agora que o contraste não existe mais, ficou muito mais fácil de se compor noise. Hoje em dia, música como um conceito está num plano muito mais expandido. Então é muito mais fácil se concentrar em um barulho [noise] puro. É o que eu acho. (KERKHOK, 1998, tradução nossa).

Por fim, dentro desse quadro - abarcando as incongruências de conformação prática e histórica que se constituíram ao redor do termo -, a música eletrônica experimental circunscreve-se ao redor das músicas ligadas ao termo, tornando-o muito próximo, em aplicação, do termo música experimental, desde que as músicas abordadas estejam de acordo com a definição menos flexível, embora suficientemente genérica, do que seria uma música eletrônica.

\subsection{Colagem musical}

A colagem musical é considerada aqui como a utilização de músicas como material para a criação e/ou execução (concretização) de obras e performances. Essas obras e performances não precisam ser estritamente musicais, pois a colagem musical não é um procedimento utilizado apenas em música: há exemplos de utilização em instalações e performances, por exemplo. Omito de material a qualificação de sonoro porque nem sempre o trabalho composicional ou de performance trata a música a partir de seus sons. Ao copiar-se notas de uma partitura, por exemplo, trabalha-se com um material musical, mas não um material sonoro (embora vá, ao final do processo, resultar em uma notação que muito provavelmente gerará sons quando interpretada). Um exemplo disso é a obra 
Prelúdio II (1971-75), para piano, de Willy Corrêa de Oliveira, em que há uma colagem de acordes famosos retirados de outras músicas: Tristão e Isolda de Wagner, Scherzo No. 1 de Chopin, Acorde Místico de Scriabin, acorde de Farben e os dois acordes do op. 19 no . 6 de Schoenberg, Sagração da Primavera e Petrouchka de Stravinsky. Corrêa de Oliveira manipula o material usado, a começar pela transcrição para piano (OLIVEIRA, 2006).

Um caso de instalação/performance é Sem Título (2009), de Tiago de Mello. O artista programa seu computador para tocar excertos de músicas com as quais tem uma relação afetiva intensa, principalmente as que ouvia em sua infância. Usando lembretes escreve sobre memórias, sensações evocadas e coisas que lembra enquanto escuta aos excertos, que vão passando um após o outro. Os lembretes são então afixados. O público é convidado a participar, fazendo o mesmo. Durante o evento, com o aumento do número de lembretes afixados, vai se construindo uma espécie de memória coletiva de vários indivíduos, canalizada pelos excertos musicais.

No âmbito da música eletrônica, a utilização de músicas quase sempre implica utilização de gravações de música - músicas que existem enquanto criações fonográficas. Estas encontram-se fixadas sob algum suporte tecnológico, seja em mídia física, como o $C D$, o DVD e o disco de vinil, ou não - um arquivo de áudio. Essa fixação prevê que essas músicas existam enquanto gravações, e que podem ser reproduzidas, usando para tal algum dispositivo de leitura adequado ao suporte em questão, como um toca-discos ou um computador, acoplados a um sistema de reprodução do som (amplificadores, caixas de som, fones de ouvido). Como toda gravação, essas músicas guardadas, ou em estado aprisionado, não apenas conservam-se assim para serem ouvidas, quando reproduzidas, mas também podem ser manipuladas de diversas formas (com ferramentas de edição e processamento de áudio), de modo a compor outras gravações.

Material (musical) é aqui circunscrito, de modo genérico, em torno dos elementos com os quais o músico trabalha, procurando excluir dessa concepção as ferramentas envolvidas nesse trabalho. Esses materiais podem servir para a elaboração dos materiais composicionais para obras e performances específicas, e de materiais pré-composicionais (que ainda precisarão ser trabalhados para virar os materiais de uma obra/performance específica $)^{56}$. No caso de materiais pré-composicionais pode existir uma etapa em que a relação de colagem musical se perde, em que o material pré-composicional apenas

56 Há quem não diferencie pré-composicional e composicional, considerando o trabalho de escolha e preparação de materiais já parte do compor, mesmo quando este não encontra-se vinculado a uma produção de obra específica. 
inspira novas etapas. No disco Third Reich \& Roll (1976) do grupo The Residents, parece haver justamente uma exploração das zonas difusas quanto a essa definição. Segundo Cutler (1993, p. 84) o disco tem

Versões de The Residents de clássicos pop e esotéricos, feitas rodando as canções para serem copiadas em uma faixa e então tocando junto com elas, adicionando parte por parte e finalmente apagando a original - então cortando e montando o todo em uma única peça.

Ou seja, o material do álbum são gravações de imitações de fonogramas musicais específicos, realizadas pelo grupo. Esse material não chega a ser uma manipulação do fonograma dessas músicas, mas pode ser encarado como uma manipulação do conteúdo destas. A imitação é encarada como manipulação, assim como um filtro específico seria, no caso de uma manipulação de áudio digital. Isso poderia levar, entretanto, a uma expansão muito grande da aplicação do termo colagem musical e que justamente parece contraprodutiva: considerar práticas apropriativas de imitação, arranjo e variação como colagens musicais simplesmente impede uma diferenciação do termo. De novo, torna-se necessário considerar a intenção envolvida no processo, com relação ao material. No caso de Swastikas on Parade, do referido álbum de The Residents, a imitação é realizada na intenção de copiar elementos dos fonogramas originais, ou seja, o nível de contribuição advindo dos músicos que copiam é menor do que músicos que improvisariam em cima da gravação (como é o caso dos exemplos de Walter e Oswald, previamente elencados). Assim, nesse contexto, mesmo com certa fragilidade conceitual, é preciso diferenciar esses termos e ponderar até onde é aceitável considerar algo como um processo ou uso de colagem musical.

É importante, no entanto, notar que a definição de colagem aqui feita versa sobre práticas composicionais e de performance. Assim fica claro que a definição estipulada se refere ao modo de fazer, mas esse modo de fazer pode não deixar rastros para a percepção. Logo, as práticas de colagem musical podem não resultar em práticas de citação e incorporação, do ponto de vista da escuta. Pode-se dizer que uma música usa procedimentos de colagem musical, mas isso não implica uma caracterização qualitativa desta como colagem ou colagem musical.

Como o material advindo de outras músicas pode ser trabalhado, está sujeito a manipulações e transformações diversas. No caso da obra supracitada de Willy, seu discurso composicional aponta para uma utilização efetiva de colagem musical na peça: 
os acordes foram retirados de obras do repertório da música de concerto, de sua História $^{57}$. Não obstante, não convencido pelas notas e seus sons, tocadas ao piano - do acorde de Tristão e Isolda -, e suspeitando da sinceridade ou do esclarecimento do compositor, poder-se-ia pensar que essa representação apenas alude aos fragmentos correspondentes de Tristão e Isolda. Pode-se pensar que a orquestração original era essencial para garantir a caracterização como colagem, e que esse acorde de Tristão e Isolda foi na verdade construído usando notas, e essas não pertencem a Wagner; que o material não era advindo de Wagner e sim dos elementos mínimos de uma linguagem musical disponível a todos.

É verdade que esse argumento desconsidera o discurso e as intenções do próprio compositor em questão; entretanto revela uma possível ambiguidade na formulação da colagem musical que, em certos casos, pode operar no fazer do músico. Este se vê em dúvida, se está a aludir ou citar uma passagem específica, ou, ainda, suspeita não ter realizado uma colagem musical, após manipular os materiais inúmeras vezes e à exaustão: agora todos eles se parecem, os que advêm de fonogramas e os que não; pode ser que eu tenha de fato criado tudo. Isto é, se tudo pertence a uma linguagem musical, então não há um tomar um material musical do outro; apenas um emprego de elementos da linguagem: uma tese que dilui a autoria, o peso da história, a ideia de originalidade. Não convencido, pode-se de repente inverter os termos e, formulando uma tese mais paranoica, recair nos argumentos de Finnissy e Kreidler, expostos no capítulo 1: a suspeita de que todas as combinações de notas já foram utilizadas e a de que todos os sons já foram sintetizados.

Porém, em ambos os casos, a retórica carrega um exagero. À exceção de Miller (2004), não foram encontrados exemplos na literatura que corroborassem essas suspeitas; mesmo no caso de Miller, quando este descreve a "ciência do ritmo" [rhythm science], trata-se de uma legitimação de uma prática artística, e não da constatação de um estado da música. Tanto que ideias importantes para a manutenção da possibilidade de separar a colagem musical de outras formas de apropriação e criação continuam válidas: a autoria, a criação do novo, da diferença, a relevância da história, de elementos sociais que marcam certas criações musicais, a referencialidade etc.

Se essas suspeitas pudessem ser levadas a sério, levariam a repensar o estatuto da colagem musical. Admitindo certa suspeita, no entanto, chega-se a um ponto

57 Willy utiliza o termo com o $H$ maiúsculo de Hegel, a dizer, como uma trajetória do Espírito. Para esclarecimentos sobre esse tipo de uso, ver Lebrun (1988). 
interessante: uma reflexão sobre o papel da apropriação na criação musical. A possibilidade de lidar em vários níveis com práticas apropriativas, bem como a possibilidade de evitá-las, ou ainda a possibilidade de traçar um plano apropriativo, em que não existam diferenças de natureza, mas apenas de grau entre as diversas práticas. Em Finnissy, há níveis de similaridade ou, inversamente, de distanciamento do material original empregado, até a criação de novos materiais; nas Verdi Transcriptions (1972-88) há a criação de peças, a partir da música de Giuseppe Verdi, procedendo de várias maneiras: por arranjos, por paráfrases mais elaboradas e reinterpretações radicais, pela recriação de atmosferas, pela recriação do impacto da música sem nenhuma alusão óbvia à mesma (DEL NUNZIO, 2006, p. 10).

Colagem musical, portanto, é entendida neste estudo como uma classe de procedimento, suficientemente abrangente para incluir procedimentos de sampleamento musical, termo equivalente à colagem musical fonográfica, ou menos usualmente amostramento musical, e também aqueles praticados no gênero plunderphonics, noções abordadas adiante.

Na obra Distill (1995), de John Wall, há uma combinação entre material retirado de CDs de música e material especialmente gravado por músicos para as composições. Não obstante, não há como determinar, pela escuta, de onde vêm os materiais, dadas as escolhas de Wall tanto quanto às amostras de músicas, não especialmente referenciais, quanto às gravações (de qualidade sonora similar a algumas das amostras, gestos parecidos, tratadas composicionalmente do mesmo modo).

Os objetos musicais da peça são apresentados como amostras, isto é, fonogramas retirados de uma gravação. São repetidos identicamente, como gravações tocadas novamente. Através da repetição idêntica o compositor indica uma maneira de trabalhar, relacionada à ideia de montagem, e possivelmente à de colagem (onde reside a dúvida quanto à proveniência dos materiais). Em 1'18" aparece um objeto heterogêneo ao conjunto - um som eletrônico, de estalidos e delays, que soa nos extremos direito e esquerdo das saídas de som. Não há entretanto sinal nenhum de que venha de uma outra música. Ele porta uma certa heterogeneidade, mas seus componentes agudos se misturam ao sul ponticello produzido por um instrumento de cordas ${ }^{58}$. Ademais, de certa forma este som prepara a entrada, em 2'19", da base repetitiva formada pela superposição de sons de clarinete e o que parece ser um batuque num instrumento de

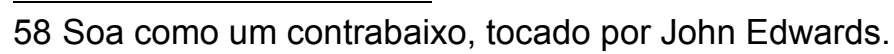


cordas grave, misturado a algumas notas do mesmo.

Porém, dentro desse foco de escuta, em 5'23" o compositor parece optar por colocar algo mais claramente advindo de um CD: uma microfonia e um som de bateria de rock. Mas mesmo aí posso estar sendo levado a concluir, dado o objetivo de tratar da colagem musical, que há uma intenção secundária (mostrar que há colagens musicais, que boa parte daquilo que eu tinha ouvido era colagem musical), quando, a ouvidos menos direcionados (ou menos influenciados por uma ideia), permanece indecidível a questão, se é que ela se faz presente. Ouvindo novamente, e mais vezes, o gesto não me chama mais a atenção: parece apenas como uma ampliação do gesto de contrabaixo de 2'16" que prepara a base de 2'19": em 5'23" o contrabaixo reaparece, mixado com a microfonia e a bateria. Esse gesto reaparece, com função de demarcação e preparação de uma mudança formal, em 7'11", e encadeia em um som de pizzicato de cordas, sem nenhum tipo de sensação de ruptura ou contraste expressivo entre os materiais.

Na literatura musical, ao se tratar de música eletroacústica, algumas aparições do termo colagem são pejorativas, como nas declarações de Risset e Stockhausen apresentadas no livro organizado por Thomas Licata, Electroacustic Music: Analytical Perspectives. Stockhausen comenta:

(...) Colagem enquanto obra era o problema da primeira metade do século - justapor coisas, como as pessoas ainda fazem em Nova lorque hoje em dia, inicialmente sem nenhuma relação; mas logo as coisas colidem. $O$ próximo passo é procurar por uma real integração - algo como uma música universal..." (apud KOHL, 2002, p. 94-599).

Risset (2002, p. xiv), por sua vez, escreve:

Parecia para mim que a música concreta permitia utilizar uma grande variedade de materiais sonoros, mas que os modos de processar e montar os sons eram rudimentares com respeito às suas riquezas, o que tornou difícil de evitar uma estética da colagem.

Ambos utilizam o termo colagem como implicando uma prática descuidada e incipiente de montagem musical. Também Boulez (1966, p. 261), em Notas para uma Enciclopédia Musical: Concreta (música), ao criticar a música concreta, corrobora essa ideia: "a questão do material (...) foi substituída por uma espécie de parada poética que 
dava continuidade à prática surrealista da colagem - pintura ou palavras."

Uma maneira de contextualizar essas posturas negativas com relação ao termo colagem é explicar o fato de que, nos estúdios analógicos das décadas de 1950 e 1960, utilizava-se fita magnética para gravação e manipulação dos sons. Assim, operações de edição de áudio tinham de ser feitas fisicamente, cortando e colando pedaços de fita. Uma estética da colagem estaria, portanto, relacionada a uma operação básica e pouco sofisticada de edição de áudio, ligada à justaposição de pedaços de fita, que resultava numa justaposição de sons - numa música basicamente monofônica, composta por sequenciamento de sons um após o outro. Françoise Barrièrre (1996, p.16) acena para essa conotação quando diz que "o som pode ser manipulado rumo à criação de sequências sonoras, organizadas tanto horizontal (colagem) quanto verticalmente (mixagem e sobreposição)" .

Ademais, dentro de um paradigma de valorização de aspectos estruturais do discurso musical - como a autorreferencialidade e autonomia da obra musical, organicidade formal e homogeneidade material ${ }^{60}$-, é compreensível a crítica a posturas que evoquem aspectos simbólicos e indiciais, e também que proponham a integração de materiais musicais heterogêneos. Dentro desse contexto, automatismos poéticos e operacionais ligados ao surrealismo e ao dadaísmo também são malvistos.

A aproximação com a colagem surrealista, exposta em Boulez, também é retratada por Schaeffer em texto publicado em 1957, segundo Palombini (1998): "Para ele [Schaeffer], as tendências estéticas da música concreta são duas: atonalidade e surrealismo."

A definição do surrealismo contida no Manifeste du Surréalisme. Poisson soluble, de André Breton, escrito em 1924, é a seguinte:

Surrealismo, subst. Puro automatismo psíquico, com o que se pretende expressar, verbalmente, por escrito ou de qualquer outra maneira, o real processo de pensamento. É o ditado do pensamento, isento do controle da razão, independente de qualquer preocupação estética ou moral. // ENCICL. Filos. O surrealismo baseia-se numa crença na realidade superior de certas formas de associação até agora desprezadas, na onipotência do sonho, na atuação descompromissada do pensamento. Tende decisivamente a destruir todos os outros mecanismos psíquicos e a ocupar o lugar deles na solução dos principais problemas da vida. (apud READ, 2001, p. 132).

60 Um panorama crítico a uma visão dita estruturalista da música é exposto em Dell'Antonio (2004), a partir de um texto de Rose Rosengard Subotnik, contido em (SUBOTNIK, 1996). 
O surrealismo traz a preocupação com um pensamento que está contido num nãopensamento, que se articula em forma de um conhecimento confuso, mas preciso, ou de uma sabedoria inconsciente. Schaeffer busca, nessa fase, uma nova musicalidade, uma musicalidade no som, uma sabedoria do ouvido e da escuta, que precisa se afastar do conhecimento musical instituído para desvelar os modos de musicalidade dos diversos ruídos.

\subsection{Sampleamento}

Sampleamento é um anglicismo, derivado de sampling, o ato de samplear (amostrar), ou de usar samples (amostras). Em música, amostras são amostras sonoras, retiradas de gravações, ou seja, fonogramas advindos de gravações sonoras. Dada a equivalência semântica exata entre os termos sample e amostra, amostramento pode ser utilizado no lugar de sampleamento, a fim de evitar o estrangeirismo. Da mesma forma, amostrador seria adequado para fazer referência ao sampler, máquina/instrumento musical que utiliza amostras de sons para construir sequências musicais (ou simplesmente um tocador de amostras, um instrumento amostrador).

A tradução para o equivalente em português tem o fim de tornar clara a acepção do termo; em inglês, sample pode ser uma amostra de qualquer coisa, de sangue a sons. Nos usos musicais costuma-se omitir a palavra que tornaria explícito o tipo da amostra (sound/music sample = sample). Quando é utilizado o termo em inglês ou o anglicismo equivalente, corre-se o risco de perder o contexto semântico maior, funcionalizando o termo e entendendo-o como exclusivo à música. Entretanto, na medida que sample e sampler são anglicismos, carregam em si esse fato, e então apontam para o contexto específico cultural mundial em que surgiram. De fato a importância da cultura estadounidense no mundo das décadas de 1970 até hoje leva à ideia de dominação cultural, ou ao menos de uma forte influência, algo com o qual temos de lidar. O fortalecimento de outra ideia, a de que o inglês seria uma língua de comunicação entre os povos, aponta para isso. O filósofo francês Bernard Stiegler radicaliza essa percepção ao dizer, no filme The Ister que seu passado "é também estado-unidense, porque agora [hoje em dia] tudo é estado-unidense" (BARISON, 2004). Assim, talvez seja necessário adotar essa condição pelo seu caráter inescapável. Uma adoção forçada: se deixo de usar sampling e 
uso sampleamento, deixo clara a origem do termo no inglês; se uso amostramento e esse uso soa como artificial e técnico, corro o risco de que este revele que estou a evitar o termo inglês sampling, de uso corrente. Ao se distanciar, deixa o traço da não-adoção. Ou seja, a objeção ao uso de amostra, amostrador e amostramento defende que sample e seus derivados já se tornaram uso corrente, e que amostradores têm como nome comercial samplers.

Essa importância estado-unidense, nesse contexto, também permeia a importância que o país assumiu, no desenvolvimento de uma tendência estética rumo à colagem (de Charles Ives a John Cage, James Tenney, e Christian Marclay, sem esquecer o rap), mas também com características que marcariam manifestações artísticas do início do período pós-moderno, ligadas a outras formas de apropriação, principalmente o pastiche (que marca boa parte da música pop). Assim, para Fredric Jameson (1997, p. xix), "o desenvolvimento das formas culturais do pós-modernismo pode ser dito como o primeiro estilo global especificamente norte-americano", que por sua vez seria a expressão de uma nova onda de "dominação militar e econômica estado-unidense, espalhada pelo mundo" (idem, p. 4$)^{61}$.

Enquanto sampleamento é um procedimento genérico, ligado à tecnologia de gravação e reprodução do som, distingue-se aqui sampleamento ou amostramento musical como o tipo de procedimento de interesse. Musical refere-se à proveniência da amostra, que advém de uma gravação de música, o que implica que a música, no caso, preexista enquanto gravação, que a música exista enquanto fonograma a ser amostrado.

Assim, grande parte do que aqui foi denominado colagem musical no âmbito da música eletrônica experimental, é sampleamento musical. Não se enquadram no termo sampleamento musical, no entanto, casos de colagens musicais em que mídias como CD e discos de vinil são manipulados sem o devido amostramento prévio.

William Mix (1952) de John Cage, por exemplo, é uma peça construída inteiramente através de sampleamento, mas não pode ser considerada colagem musical; tampouco contém colagens musicais. Seus sons possíveis, determinados antes da montagem da peça, devem pertencer a uma das seis categorias, conforme predeterminado. Todas essas estipulam sons, não se referindo a músicas: A - sons de

610 trecho completo versa: "(...) postmodern culture is the internal and superstructural expression of a whole new wave of American military and economic domination throughout the world: in this sense, as throughout class history, the underside of culture is blood, torture, death, and terror." (Jameson, 1997, p. 4). 
cidade; B - sons do campo; C - sons eletrônicos; D - sons produzidos manualmente; E sons produzidos pelo vento; F - pequenos sons, que precisam ser amplificados ${ }^{62}$.

O grupo Furt, formado por Paul Obemeyer e Richard Barrett, trabalha com uma concepção de sampleamento que Barrett considera instrumental, em oposição à concepção do sampleamento como colagem (com uma estética da colagem). Os materiais sonoros funcionam como os instrumentos de um percussionista e/ou como personalidades, sugerindo um modo de tocar ou um modo de expressão. Então, apesar de algumas exceções notáveis, em que há coexistência de ambas as formas - Volksmusik (2002) e Johannes-Passion (1993-2003) -, raramente há utilização dos sons enquanto citações (BIANCHI, 2005). As colagens musicais utilizadas são normalmente transformadas a ponto de se tornarem irreconhecíveis, mesmo para os membros do duo.

Mesmo que haja a preocupação em diminuir a possibilidade do reconhecimento das fontes musicais, isto é, da identificação das músicas das quais advêm os fragmentos amostrados, o sampleamento musical seria, segundo Riddell (2001, p. 337), uma prática de apropriação em que não apenas o conteúdo sonoro seria explorado e o timbre da fonte amostrada capturado, mas também informações sobre a performance envolvida e a ambientação da gravação em questão, bem como aspectos técnico-tecnológicos envolvidos.

No exemplo citado de John Wall (Distill) há uma preocupação deliberada em nivelar as diferentes sonoridades das diferentes amostras, de modo que componham organicamente um todo consistente quanto à sonoridade da peça. Essa preocupação vai na contramão das possibilidades apontadas por Riddell, justamente por uma vontade do compositor de trabalhar contra a tendência de multiplicação da diversidade das sonoridades nas práticas de sampleamento: diversidades instrumentais, técnicas de gravação, ambiência sonora, meios tecnológicos e tipos de mixagem. Todas deixam resíduos e/ou traços sonoros nas amostras, evidenciadas principalmente por rupturas ocasionadas por mudanças abruptas de instrumentação e fontes sonoras, de tipos de microfonação (microfonações próximas transparecem menos o som da sala, microfonações ORTF transparecem bastante, gravações em linha podem apresentar a sensação de um não-espaço), tipos de reverberação (usada tanto como efeito, como na música post-punk da década de $1980^{63}$, quanto como indicação do tipo de espaço

62 Disponível em: <http://www.johncage.info/workscage/williamsmix.html>. Acesso em: 23 mai. 2012.

63 Normalmente, como é o caso em bandas como Cocteau Twins, efeitos de chorus e reverb são aplicados localizadamente, a um instrumento, parte do conjunto de instrumentos ou diferenciadamente entre os instrumentos. Entretanto, na mixagem, há uma estética que preserva a noção de realismo - isto é, que 
acústico onde foi feita a gravação); de reforço espectral específico (o modo como uma fonte sonora tem certos parciais espectrais acentuados e outros atenuados devido a características de refração e absorção sonora da sala de gravação ou dos filtros utilizados); de transparência sonora (dos ruídos que cada mídia traz consigo, quando da gravação); de panorâmicos e equalização; e tipos de posicionamento aural das fontes sonoras (a posição das fontes pode ser determinada e fixa, com uma estética realista ou hiper-realista, ou ainda essa posição pode ser irrelevante, e os sons livres para passear no espaço panorâmico).

Improviso em Branco e Preto e Vermelho (Carta às Videntes) (2004), de Mário Del Nunzio, explora essas diferenciações multiplicadas: potências do sampleamento como modo de composição. Seus materiais principais pertencem a duas categorias dicotômicas: solos de baterias de bandas de rock (de discos que privilegiam a atuação dos guitarristas, discos de guitarristas) e excertos de percussão de música contemporânea. Diz Del Nunzio:

\begin{abstract}
A partir desses dois tipos de material eu trabalhei com a suposição de que os excertos escolhidos de bandas de rock contêm uma gestualidade e tipos de articulação bastante próximos, mas com características sonoras advindas de escolhas timbrísticas e processos de gravação que as tornam bastante individualizadas. Uma anotação que eu tenho aqui da época diz o seguinte: '[Gesto padronizado versus timbres individuais; ênfase na preocupação com som (seguida pela preocupação com a realização virtuosística da performance); performance voltada à demonstração de domínio em determinados padrões realizados de modo altamente energético com grande velocidade].' E essas características das bandas de rock se contrapõem ao que ocorre no âmbito da 'percussão contemporânea', nas quais os tipos de articulação e gestualidade são bastante diversos, mas não está presente, por exemplo, a preocupação com os tipos de gravação ou o que isso influencia na característica sonora da obra. (informação pessoal ${ }^{64}$ ).
\end{abstract}

No caso dos solos de bateria há uma série de delimitações de gênero quanto às articulações e gestualidade, o que leva a um espaço de fantasia e criação no tratamento dos timbres e procedimentos de gravação; no caso da percussão contemporânea há uma delimitação de gênero quanto à gravação: ela deve ser uma documentação da performance da obra, e maximamente transparente - o espaço de criação e fantasia é

pretende apresentar a banda como se seus integrantes estivessem posicionados num espaço de estúdio, tocando todos juntos, cada um na sua posição. Assim, como há a construção de um espaço acústico comum a todos, há a percepção de que uma sonoridade específica de reverb não resulta da sala, porque varia entre os instrumentos, todos (supostamente) dispostos no mesmo espaço.

64 Entrevista com o autor, em São Paulo, em 2012. 
manifestado nas opções pessoais de cada compositor, em cada obra, a respeito das articulações, instrumentação e gestualidade.

A peça então é construída encadeando e fundindo amostras diversas, de um modo bastante livre. Procura similaridades possíveis, caso a caso, criando arcos gestuais entre várias amostras, com a ajuda de sons mais harmônicos, retirados de outras músicas do repertório contemporâneo ${ }^{65}$ (idem). Assim, tecendo frases, cria-se uma continuidade que contrapõe as especificidades de cada amostra. Articula continuidade e fragmentação. Em cada amostra há outro nível de escuta, presente pela proximidade de amostras diferentes, com qualidades diferentes - diferença favorecida pela escolha de trabalhar apenas com sons percussivos (isto é, pelo estabelecimento de uma semelhança, que serve como referencial; um fixo que permite comparar o que varia). Essa escuta perscruta os detalhes, as variações de gravação e as contraposições de instrumentários utilizados, mas também as sutilezas de mixagem: níveis de compressão do áudio, equalizações diversas da caixa, salas mais ou menos reverberantes.

Pode ser que a música contemporânea de certo modo tenha relegado a preocupação com a especificidade da gravação para as músicas eletroacústica e eletrônica experimental, circundando assim um domínio diferente de preocupações. Del Nunzio ajuda a trazer essa questão à tona. Os exemplos de rock utilizam declaradamente o estúdio e a gravação na construção da identidade de seu som. Há sobre eles, entretanto, uma pressão para que essa identidade seja replicada, ao vivo, em shows. Talvez seja algo que os percussionistas contemporâneos queiram evitar: equipamentos e necessidades técnicas adicionais nos concertos. Que as gravações possam ter um estatuto autônomo parece algo reservado àquelas práticas que não envolvem propriamente a performance das obras gravadas.

Sobre o termo sampling, Davies (1996, p. 3) escreve:

Desde o final da década de 1970 o termo sampling (amostramento) tem sido usado em música para denominar o método pelo qual instrumentos musicais especiais ou aparatos digitais 'gravam' sons externos para subsequente ressíntese. O termo foi, não obstante, originalmente usado para descrever como uma forma de onda de qualquer som poderia ser analisada e/ou sintetizada em PCM simplesmente através da tomada de medida de sua amplitude ou nível de intensidade a cada sequência de

65 São elas: Karlheinz Stockhausen: Gruppen (Orquestra Filarmônica de Berlim, Claudio Abbado); lannis Xenakis: Pleiades (Kroumata Percussion Ensemble); lannis Xenakis: Okho (Trio Le Cercle); lannis Xenakis: Psappha (Gert Mortensen); James Dillon: Ti-re-Ti-ke-Dha (Guy Frisch); Bruno Maderna: Hyperion (Asko Ensemble, Peter Eötvös); Marc Monnet: Le Cirque (Armand Angster); Allain Gaussain: Chakra (Quarteto Arditti). 
'pedaços' verticais tomados milhares de vezes por segundo.

Concluindo: "Pela falta de termos melhores, sampling é usado neste estudo para descrever todo esses métodos de armazenamento e reuso de som, usando tanto técnicas analógicas quanto digitais." (idem, p. 4).

\subsection{Plunderphonics}

Plunderphonics, do verbo em inglês, to plunder (pilhar), mais phonics (fônicos, referentes aos sons da fala), pode ser traduzido como pilhagem sonora, já que a terminação, nesse caso, aproxima-se de outros nomes como sterophonic (estereofônico), em que, apesar da raiz grega do sufixo remeter à voz, a acepção corrente é ligada ao som como fenômeno geral (não circunscrito à noção de voz ou fala).

O termo foi criado por John Oswald e lançado em seu artigo de 1985, Plunderphonics, or Audio Piracy as a Compositional Prerogative [Pilhagem sonora, ou pirataria de áudio como uma prerrogativa composicional] (OSWALD, 1985). No artigo o autor não define plunderphonics, mas insere o termo no conjunto de práticas que poderiam ser descritas como colagens musicais. Não obstante, em entrevista com Norm Igma (OSWALD, 2000, p.9), plunderphonics é referido de modo mais específico como "a transformação radical de música muito familiar" (com a qual muitos possuem familiaridade). Suas declarações seguintes apontam para a necessidade de explorar essa familiaridade óbvia e de ver essa prática como uma paródia - mas não necessariamente engraçada.

Esse afunilamento de sentido aproxima-se mais do conteúdo publicado em seu disco Plunderphonic (primeiro, um EP com 4 peças, lançado em 1988; depois, um CD com 24 peças, lançado em 198966); assim como de sua peça Plexure, de 1993.

Pocket (1987), de Oswald, desconstrói uma gravação de Corner Pocket, por Harry James and His Big Band, um tema de Count Basie composto por Freddie Green em 1959. A música tem um característico motivo-arpejo, repetido várias vezes; primeiro sem variações, e depois variado em diversas transposições, formando uma trajetória melódica. O final desse ciclo de repetições idênticas é articulado por acordes pontuados em tutti. De 
resto, a música flui animada e leve, com os acentos e desvios rítmicos característicos do jazz orquestral, com swing [balanço]. Na remodelação de Oswald, a música agora vê-se propensa a estacionar em ciclos mecânicos [loops], evidenciando dois tipos de repetição do mesmo - humana e maquinal - e uma pergunta: não há vezes em que se confundem? Pocket se põe a pular de um trecho a outro, não só como maneira de terminar as frases repetidas (um modo menos instrumental e duro de passar de uma parte da música para outra), mas como um modo padrão. O que era uma dança vibrante [o swing], com espaços para incursões típicas do bebop de Count Basie, de um solo de bateria, por exemplo, foi substituído por uma gagueira generalizada, um andar trôpego. Essa operação de criação de respostas para características da música original também revela um parentesco próximo com o que um disco de vinil em má condições faria, um disco antigo, da época da própria prensagem da gravação original. Saltos consecutivos entre trechos da música procuram similaridades timbrísticas e/ou harmônicas, numa caminhada robótica e desviante até o próximo buraco.

Outros comentários de Oswald, na entrevista que compõe o lançamento da coletânea Plunderphonics 69/96 (contendo obras feitas entre 1969 e 1996), apontam para o plunderphonics como um gênero musical : "Em 1986 eu estava começando a me convencer que plunderphonics poderia ser visto como um gênero distinto, e eu não tinha exatamente encontrado a nomenclatura." (OSWALD, 2001, p. 43) Um gênero realizado com "recusos familiares e disponíveis para todos" (idem, p. 6), cujo resultado perceptivo se apoiaria bastante sobre a "reconhecibilidade da fonte na transformação" (idem, p. 14). O autor também menciona a possibilidade do polyplunderphonics (ibidem, p. 33), sem maiores explicações, e de "text-based plunderphonics" [plunderphonics baseados em textos] (idem, p. 29), o que remonta à origem da prática de colagens de Oswald, a partir de gravações de voz realizados por William Burroughs ${ }^{67}$ (apud IAZZETTA, 2009, p. 145), e influenciado pelas suas ideias de montagem sonora - de que "à medida que esses materiais fossem desfigurados e descontextualizados, eles trariam uma 'libertação de velhas associações confinadas"'.

Chris Cutler, em seu ensaio Plunderphonia (nome que faz referência ao fazer soar obras de pilhagem sonora), adota a retórica de que plunderphonics é uma prática apropriativa, que utiliza fonogramas de músicas para produzir fonogramas de músicas:

67 BURROUGHS, W. The Ticket that Exploded. Paris, Olympia Press, 1962. 
Assim, a prática do plunderphonics desmantela de maneira radical três pilares centrais do paradigma da música erudita: originalidade - utiliza apenas cópias; individualidade - fala apenas pela voz de outros; e direitos autorais - cuja transgressão é sua própria condição de existência." (CUTLER, 2004, p. 143).

Os sons utilizados carregam a habilidade dual de não apenas se referirem às suas fontes originais (a gravação dos quais foram apropriados), mas de (certo modo) serem essas fontes, agora em outros contextos, ressignificados. Assim, Cutler aponta o plunderphonics mais especificamente como uma prática em que todo material advém de gravações $^{68}$, reforçando a característica autorreflexiva da fonografia (de uma gravação se referir a outra gravação).

lazzetta relaciona o termo a um "furto sonoro" e também comenta sobre o tipo de utilização do material, dentro dessa prática, seguindo a mesma linha de pensamento exposta acima por Oswald: "Usadas como matéria-prima para compor outras músicas, as gravações facilmente convertem-se em elementos novos, ao mesmo tempo conectados à sua origem fonográfica, mas também abertos a adquirir outros significados (...)" (IAZZETTA, 2009, p.146).

As peças construídas sob a égide da pilhagem sonora são, portanto, formadas inteiramente por procedimentos de colagem musical (com a especificidade com relação à natureza do material utilizado, advindo de músicas familiares). É comum, em virtude de tal especificidade, ou ainda por Oswald ter dado quase o mesmo nome à sua coletânea de músicas de 1988-9, que exista certa confusão no uso do termo ou ainda, de um uso múltiplo deste. O emprego deste ora dá a entender que plunderphonics é um gênero dentro da música eletrônica experimental, ora de que é uma forma musical específica ; ou ainda de que é um projeto artístico restrito ao próprio Oswald ${ }^{69}$ - como aparece em Schwarz (2006, p. 11): "Plunderphonics (...) é o projeto artístico de John Oswald, no qual recorta ${ }^{70}$ músicas gravadas".

O termo pilhagem sonora [plunderphonics], ao aludir a pilhagem e pirataria (nem sempre encaradas como ações positivas, e que implicam rebeldia e contravenções às leis

68 Apesar dos inúmeros exemplos musicais e condução discursiva na qual podemos presumir que Cutler identifica gravação e música, o texto não expõe a necessidade explícita de que esses sons gravados sejam música.

69 A própria entrevista com Norm Igma é um caso criador de confusão nesse sentido, quando o termo plunderphonics é colocado ao lado e em pé de igualdade com um projeto específico anterior de Oswald, as Mystey Tapes [Fitas Misteriosas], (2000, p. 9).

70 "Plunderphonics (...) is John Oswald's artistic project of cutting up recorded music". "Cutting-up" evoca cut-up, técnica de montagem textual por um procedimento de colagem, atribuída a Brion Gysin e popularizada por William S. Burroughs. 
ainda vigentes de direitos autorais) é criticado por Simon Waters como infeliz (WATERS, 2000, p. 68) $)^{71}$. É também por vezes interpretado como um gênero, ligado especificamente à produção de Oswald, como demonstra o compositor John Wall em entrevista, sobre ter sua produção inicial (anterior à obra Hylic, 2003) classificada como plunderphonics (2008): "Eu disse muitas vezes que eu não trato o amostramento como um gesto político, contra os direitos autorais, da mesma forma que John Oswald fez." (idem).

Em entrevista, o compositor Richard Barrett pontua:

O propósito do 'plunderphonics' parece ser de que os sons sejam colocados entre aspas, de modo que o ouvinte supostamente reconheça, se não as origens exatas, ao menos um sentido de ambientação cultural, e então reconheça a 'diferença' desse uso para com a intenção estética das músicas dos quais foram retirados esses sons; entenda de que forma foram subvertidos os sons - removidos de seu contexto original e colocados em outro contexto, contradizendo a sua [dos sons] função original (mais comumente, comercial). (BIANCHI, 2005).

Esse entendimento aponta plunderphonics como procedimento, comentando com acuidade intenções presentes nas concepções de Oswald e Cutler.

Por sua vez, Cutler irá se referir ao procedimento da prática da pilhagem sonora como plundering [pilhagem], ou simplesmente através das conjugações do verbo pilhar: to plunder (uma gravação pode então ser pilhada - plundered). A uma amostra musical correspondente, amostra pilhada, Oswald (2001, p. 17) dá o nome de plunderphone: "um plunderphone é uma citação sônica reconhecível, realizada usando o próprio som de algo familiar que já foi gravado"; o plunderphone deve ser "Reconhecível para pelo menos um monte de gente (...) A peça pode se tornar menos reconhecível quando ouvimos inteira, mas para permanecer plunderfônica a derivação precisa manter um grau substancial de seu caráter original" (idem, p. 32). O termo seria então equivalente a uma amostra musical reconhecível, mas eletrônica, ou mais especificamente fonográfica.

\subsection{Citação}

A colagem musical pode ser entendida como uma prática de citação. Como citação

71 A insistência de Oswald em relacionar a prática à pirataria é uma provocação que serve como chamariz para discutir questões relacionadas a legislação e jurisprudência das leis de direitos autorais, e a problemática relação destas com algumas práticas criativas musicais. 
é um termo bastante amplo e usado em diversas áreas, citar em uma música não se trata necessariamente de uma citação de música (uma colagem musical), podendo ser citação de outro artefato cultural (texto, imagem, o som de um vídeo ou uma instalação) ou uma menção a um nome (diz-se, nesta passagem ele cita fulano). Entretanto, a princípio, a citação em música tende a ser uma colagem musical, especialmente em música instrumental.

$\mathrm{Na}$ abordagem de textos faz-se a distinção entre paráfrase e citação, a partir do texto (do resultado textual) e não da intenção (o modo como o texto é escrito). Deste ponto de vista, grosseiramente, a citação mantém o conteúdo do que foi citado (usando como expediente as aspas de citação), enquanto a paráfrase mantém a ideia (o significado da mensagem), reelaborando o conteúdo (as palavras usadas, a frase). A transposição musical direta disso seria uma analogia entre alusão e paráfrase, e também entre colagem musical e citação, mas isso não confere. Primeiro há, para a paráfrase, a noção de manutenção do significado perante a reescrita, que não é diretamente transposta para música (perguntar-se-ia: o que é o significado em tal passagem de música?). Variações e arranjos vêm como possíveis análogos, dada a manutenção de uma identidade, que pode ser tomada como ideia - um tema, uma certa progressão harmônica (como nas Variações Goldberg, de Bach), certos motivos e ritmos, um tipo de pertencimento. Alusões musicais também podem ser encaradas sob esse ponto de vista, mas de modo mais vago, dada a dificuldade em definir se há ou não um significado e se ele é mantido de fato. De fato há nas alusões uma dubiedade quanto à apropriação, pois ter-se-ia que tomar a apropriação como referente a ideias gerais, amplas, para incluir assim a alusão enquanto apropriação. Será melhor manter a alusão como um referir-se a indiretamente, algo que mantem distância do aludido.

Momentum I (Para Giacinto Scelsi II) (2008-11), de Jean-Pierre Caron, estabelece um crescendo a partir da densificação de uma camada sonora contínua, acrescida de outros eventos sonoros mais pontuais. Prossegue dessa forma até $8^{\prime} 50^{72}$, quando aparece uma segunda camada, de glissandos eletrônicos, mais pronunciadamente. Quando o crescendo atinge seu ápice há a utilização de timbres distorcidos (sinais de áudio clipados), antes da camada receder e deixar apenas um trecho de um dos quartetos de cordas de Scelsi. Pode-se dizer que Momentum I alude ao gênero noise, e assim aponta para uma reavaliação da obra de Scelsi, em relação a esse gênero, bem como

$72 \mathrm{~A}$ referência usada aqui é a versão estéreo de 2011. Disponível em: <http://soundcloud.com/j-pcaron/momentum-i-for-giacinto-scelsi>. Acesso em: 17 mar. 2012. 
chama a atenção para a direcionalidade estrutural contida nas obras de Scelsi em geral, como argumento secundário. Segundo o compositor, "à medida que a obra avança, ela sai de texturas bem artificiais, estilo eletroacústico, para texturas orquestrais, para sons muito saturados no final, encontrando-se sim com uma prática noise." (Informação pessoal $^{73}$ )

As amostras, quando manipuladas e alteradas, geram versões diferentes, às vezes irreconhecíveis, dos seus materiais iniciais - de modo que não existe garantia da manutenção de identidade, muito menos de aspectos semânticos envolvidos.. Por vezes essas modificações levam à percepção de um sentido indireto - que está presente, mas indiretamente. Não se trata propriamente de som, mas um argumento, um comentário implícito - abrem as portas para uma hermenêutica, são convites à interpretação. Esse sentido pode ser identificado e/ou interpretado como uma alusão, normalmente a um estilo, uma prática, uma ideia. O compositor pode ter efetivamente uma intenção alusiva, mas também ela pode ser uma construção daquele que interpreta, ouve, pensa sobre, tanto como pode ser um pensamento contido na obra, mas não intencionado. No caso da peça de Caron há alusão a um gênero, que se dá pela combinação de três fatores: através de uma estruturação musical similar a uma das estruturações convencionadas do gênero noise (mas não exclusivas a este) - similar, por exemplo, aos arcos de crescendos, densificação e saturação estabelecidos por Zbigniew Zarkowski em diversos shows e obras; há também a entrada dos glissandos sintéticos, que gera uma sobreposição de camadas em crescendo; por fim, há a saturação timbrística, atípica em sons advindos de instrumentos de corda, que sugere conter em si a ideia da saturação, explorada exaustivamente pelos artistas do noise. Essa combinação permite uma caracterização indireta, não certeira, da peça como referencial: ela alude.

Quanto à citação, em textos, ela mantém o trecho citado, tal como no original. As aspas indicam que se trata de um material escrito por outro autor, que é indicado, acompanhado de referências adicionais quando conveniente, localização da citação, publicação etc. A música, entretanto, não tem um expediente equivalente e não parecem haver tentativas consistentes no desenvolvimento de uma analogia ${ }^{74}$. Assim, uma

73 Caron, J.P. Mensagem recebida pelo endereço <jpccaron@gmail.com>.

74 Seriam exemplos: um som característico que indica entrada e saída de uma citação; uma parte de vídeo em que apareçam informações sobre os trechos citados; metadados nos arquivos de áudio que indiquem os materiais utilizados, quando a música é reproduzida em um software específico. Na cena Einleitung in die Musiksoziologie [Introdução à Musicologia], da obra Feeds. Hören TV (2009-10), de Johannes Kreidler, os nomes dos estilos citados são projetados em um telão. Uma orquestra toca um som que serve como sinal de que a citação acabou. No vídeo de Beethoven's Eroica: Opening Chords (2012), 
transposição direta seria considerar que o material musical utilizado, quando não transformado e com intenção de se referir ao original, seja então uma citação. Colagens musicais que não alteram significativamente o que está sendo colado, nesse sentido, são citações propriamente ditas. Boa parte da música eletrônica de Noah Creshevsky, por exemplo, não altera os fragmentos utilizados - ao menos não de forma a gerar mudanças de conteúdo perceptíveis (há a sempre a possibilidade de pequenas alterações de amplitude e quantização). O compositor trabalha realizando operações relativamente simples de edição e mixagem. Resta saber se há de fato a intenção de fazer referências às fontes musicais, ou se, como na produção de Johannes Kreidler, há a tendência a se considerar a referência aos diferentes estilos e tipos de gravação (classes e categoriais) mais importante do que as músicas individuais. Há nesse caso uma citação de estilos? Não seria mais adequado afirmar que há, efetivamente, contraste de estilos (musicais e fonográficos)? Vê-se assim uma dificuldade em comparar e estabelecer categorizações quanto aos procedimentos empregados.

Isso leva a pensar que um livro feito inteiramente de citações ou é um breviário de citações, que em si nada mais é que uma coletânea de fragmentos (algo que poderia ser feito em música), ou uma colagem em que a própria figura da citação se dissolve num excesso de referências específicas. Essa saturação, por sua vez, conduz à desvalorização da individualidade de cada fragmento, bem como à valorização de sua atuação junto ao conjunto de fragmentos: como contribui para a continuidade de uma sequência, como gera diferenças dentro dessa sequência, por diferir em estilo, ênfase etc. Várias obras do álbum Hyperrealism (2003), de Creshevsky, podem ser assim interpretadas: não se trata de identificar de onde vieram os fragmentos, ou o que estão a citar, se é que estão; mas como eles, contribuindo para o prosseguimento dos fraseados agitados e incansáveis, manifestam diferenças de gravação, instrumentação, estilo.

Citação, em outra acepção, é apenas o referir-se a. Nesse caso, a explicação de Oswald procede: "Assobiar um compasso de Density 21.5 é uma citação tradicional" (OSWALD, 2001, p. 17); ou seja, o que importa é uma ideia de articulação e desenho melódico que faça referência à obra para flauta solo. A pergunta é: isso não seria propriamente definido como uma alusão? A intenção de se referir é direta demais para tal; logo, trata-se mesmo de uma citação.

A colagem musical foi definida permitindo toda uma série de transformações, e 
estas não podem ser encaradas diretamente como citações musicais numa transposição direta; há ainda a dificuldade em considerá-las citações em todos os casos, se pensada a intenção de referência à fonte. Deste modo, pode-se pensar a questão a partir de outro referencial: a colagem musical como análoga à operação de recorte de um texto, que toma a imagem das palavras e seu espaço visual como elementos integrantes do texto. Assim, mesmo que cada letra seja recortada de uma fonte diferente, a formação de determinadas palavras e frases garante a continuidade de leitura, enquanto os diferentes tipos, tamanhos, cores e fundos evidenciam diferenças. Ou, contrariamente, a manutenção de um tipo específico ou a construção de certas transições entre cores de fundo fornecem o fio condutor para uma sequência ininteligível de letras. Ademais, os resíduos - tudo que não é parâmetro, que não é elemento constituinte -, também são transportados: esses pequenos amassados do papel, um pequeno rasgo, o barulho da mão deslizando sobre o braço do violão.

Se a citação (musical) pode ser encarada como procedimento de incorporação de conteúdo a uma música, estilo ou característica musical, cuja intenção é fazer referência à fonte citada (música, estilo ou característica), mais genérica ou especificamente caracterizada (nome ou algum componente - melodia, ritmo etc.), resta saber se ela pode ou não se confundir com a própria fonte citada. Porque há, ligada à colagem musical, uma ideia de que esses materiais foram retirados das músicas das quais vieram - isto é, que se está a trabalhar de fato com as músicas como material, e não com algo que faz referência àquela música. Para tanto, há de se lembrar que um trecho citado musicalmente pode ser, em sua fonte, virtualmente o mesmo. Esse trecho, idêntico ao trecho correspondente na fonte, faz referência a outras informações e características da fonte que ali não estão. Ou seja, em música, há a princípio a possibilidade de confusão entre a citação e sua fonte. No entanto, esta é afastada pelo fato da fonte ser completa, enquanto a citação é um fragmento que, por sua incompletude, remete à fonte, como a parte ao todo.

Pode-se no entanto estipular uma diferença de ênfase entre dois tipos de presença: uma que envolve prioritariamente o referir-se a algo, e outra que envolve prioritariamente o colocar algo. Ambas são apresentações do material utilizado, isto é, não há dualidade apresentação/representação em relação ao material. A questão incide se a presença reforça o que não está ali ou, contrariamente, o que está ali. Desta forma, é estabelecida uma diferença poética: dado um empuxo rumo ao referir-se a, coloca-se a citação como 
mais próxima à evocação, ao passo que se considera a colagem musical eletrônica como mais próxima à invocação. Justifica-se essa opção pela consideração que a fonografia inscreve o que mais se aproxima de um caráter particular de uma execução de música - o timbre. Esse particular pode ser capturado e individualizado - de tal forma a dar a ideia de ser um ícone de si mesmo ${ }^{75}$. Ou seja, quando individualizado e assim dominado, o timbre, por ser uma característica complexa, fornece uma noção de inequivocidade, por exemplo: um grito do Michael Jackson; não poderia ser um grito de Mick Jagger? Não, há como uma etiqueta sonora apregoada nesse som. Desse fato advém a retórica de Oswald, replicada por Cutler. Norm Igma, em entrevista, exclama: "Realmente soa como Dolly Parton e Elvis Presley!", ao que Oswald responde: "São eles. Estas não são versões cover, imitações, personificações ou farsas. São performances autênticas que nunca foram lançadas antes." (OSWALD, 2001, p. 17).

Uma gravação é caracterizada por conter sons específicos. As colagens musicais eletrônicas utilizam esses sons e portanto aquilo que caracteriza as gravações de música a qual recorrem. Se há identificação entre gravação de música e música, pode-se considerar que a música são os sons, e que a música acontecendo são os sons sendo reproduzidos. Dessa forma, colagens musicais fonográficas trazem a gravação como presença - algo que pode ser entendido como a música per se, dentro desse contexto. Há ali, de fato, músicas alheias; elas foram retiradas, furtadas, pilhadas, deslocadas de seus locais de origem e agora se encontram em outro território. Desta forma pode-se dizer que, se essas gravações guardam a memória de suas atividades, quando voltam a seu(s) outro(s) local(is) de aparição, não são mais as mesmas; carregam consigo a experiência de outros contextos. E esse movimento é imputado às gravações pelos ouvintes que testemunharam seu(s) deslocamento(s). Na colagem realizada em partituras, por exemplo, pela notação possuir elementos mínimos e blocos de construção, gera-se uma classe de elementos gerais e não individualizados; elementos de esquecimento e não de memória. Acima de tudo, elementos cujos sons variam, elementos não etiquetados.

Disso não decorre que todas as gravações sejam etiquetadas. É preciso que o timbre seja domado, que seja marcado um ponto no plano timbrístico, que seja individualizado para que outros possam nomeá-lo concordantemente. Por exemplo, numa nota reconhecer o tema My Favourite Things na interpretação de John Coltrane, lançada em 1961. Isso sem que se entre no mérito de o som advir ou não da gravação original - o

75 Poder-se-ia perguntar: qual a representação icônica do desenho de um quadrado? Dir-se-ia aqui que é o próprio desenho do quadrado. 
som é o mesmo. Aceita-se facilmente os conceitos de transparência tecnológica e altafidelidade de reprodução sonora. Ou então, alternativamente, há algo como uma estrutura sonora que se mantém, a despeito de certos desvios, transduções e transposições.

Quando não há essa especificidade da replicação exata do som ou da manutenção de um timbre específico e particular (como é o caso nas colagens musicais nãoeletrônicas, em que o material é reinterpretado - seu som é outro e só os parâmetros se mantêm), há uma evocação da música colada: somos nós os ouvintes que rememoramos a música; esta continua no seu devido local. É diferente, no caso, do que foi chamado plunderphone. Toma-se um som de uma gravação: eles advieram de processos de gravação em que um determinado músico ou grupo atuou. Essa atuação produziu um timbre individual próprio àquela gravação, que inclusive resiste a várias transformações do som daquela gravação (reconhece-se a fonte musical mesmo sob algumas transposições, retrogradações, filtros etc.) Esse timbre garante que uma série de traços sejam impressos ao som - são a marca da autenticidade da performance fixada no som. Uma vez possível estabelecer e reconhecer essa qualidade, então, aquele som, com aquele timbre, ganha também uma aura de autenticidade. Desta forma, uma cadeia metonímica é construída e os processos fonográficos envolvidos na produção de um som característico, a partir de uma performance de Elvis, passa a ser referido como o som produzido por Elvis numa gravação, e nomeado o som de Elvis, por sua vez chamado de Elvis. Elvis, então, passa a designar essa transnominação, essa redução de palavras, mas também o modo como a autenticidade do seu som passa a ser a sua autenticidade ${ }^{76}$. De novo, não é a gravação original que é autêntica, mas o seu som. Esse som pode ser replicado e, em meio à tecnologia digital, sem perda de qualidade de uma cópia a outra.

Assim, em Dont, de Oswald, há uma invocação de Elvis - do que Elvis passou a ser. Há também uma performance de Elvis, isto é, o som inequívoco de um fonograma contendo uma atuação de Elvis. Por isso a brincadeira de Oswald de 'Elvis não morreu' ao fazê-lo contracenar com músicos de carne e osso (vide tópico 2.1).

Fantasmas são reais, memórias se atualizam e existem no presente: invocação fantasmática, evocação presentificante. Com um pouco de imaginação pode-se enxergar essa dualidade no neologismo de Oswald, Electroquote [eletrocitação, ou citação eletrônica] ${ }^{77}$. Este pode ser explicado como uma citação eletrônica, mas a similaridade

76 Contribuem para isso as já citadas ideias de fidelidade e transparência dos equipamentos de gravação e reprodução do som. Um equipamento ruidoso acaba por evidenciar seus ruídos como a marca de que há, efetivamente, uma mídia e um meio, e que está a agir sob uma gravação.

77 A palavra também aparece em Cutler (2004, p.142) ao lado de outro neologismo: macrosamples [macro- 
com eletrocutar [electrocute - execução de morte através de choque elétrico] não deve ser ignorada: a morte alegórica do que foi eletrocutado se dá pela revelação de que o que deveria ser uma citação, que assegura um distanciamento polido do original, é na verdade um pedaço da música original, deslocado, transformado. Na acepção original do termo, entretanto, Oswald diz ser uma citação eletrônica (feita por meios eletrônicos) devidamente creditada (a fonte musical é identificada por quem citou). (HOLM-HUDSON, 1997)

Mas afetar a fonte musical não é exclusivo da colagem musical. Pode-se estabelecer meios de criação em que as citações, confrontadas entre si ou ao contexto, não apenas referenciem as fontes distantes, mas proponham uma reavaliação destas, através justamente desses confrontos - como as práticas citacionais da paródia e da sátira. Aqui cabe um porém: a citação, por não intentar confundir-se com sua própria fonte citacional, tende à incompletude constitutiva e à incorporação parcial de conteúdos. Estas características salvaguardam a existência da fonte como algo autônomo e exterior, estabelecendo um vetor de comentário e crítica na citação. Como proposto, esse vetor pode de fato promover uma reavaliação das fontes. Diferentemente das amostras musicais reconhecíveis, em teoria, não se está alterando o original, mas sim alterando a percepção que se tem do original ${ }^{78}$.

Existe, em tese, uma zona de intersecção problematizante (difusa) entre citação, citação musical e colagem musical. Estabeleceu-se aqui a dificuldade de tecer uma relação clara entre as três e mostrou-se a complexidade envolvida. Mostro agora um exemplo, a fim de continuar a expor nuances nas relações entre colagem musical e citação.

No terceiro movimento de sua Sinfonia (1968), para orquestra e oito vozes amplificadas, Luciano Berio faz uma colagem envolvendo o terceiro movimento da Segunda Sinfonia de Gustav Mahler. A escuta da obra de Berio transfigura a obra de Mahler, dada a dificuldade decorrente de não relacioná-las na memória e na escuta, de forma consideravelmente direta. As diversas outras obras citadas durante esse movimento, por outro lado, são apenas referenciadas; o jogo que se faz em relação a estas é apenas o de descobrir quais as fontes citadas. Interpretando essa impressão

amostras], que seriam colagens de trechos de maior duração - um trecho inteiro advindo de uma gravação sonora, inserido em outra.

78 Isto é, essa operação não abala a autonomia teórica do original. Em acordo com essa percepção, a tese especulativa de Paul D. Miller de "fim do original", esboçada em Rythm Science (2004), evoca procedimentos de colagem musical. 
como uma declaração relativa à história da música, pode-se concluir: enquanto a música de Mahler permanece atual, as outras fontes citadas são historicizadas - refazem uma linhagem valorizada por Berio. As outras músicas são evocadas, a de Mahler é invocada. O terceiro movimento de Mahler contém em possibilidade o terceiro de Berio, por acréscimo de elementos, enquanto o de Berio contém o segundo de Mahler, por filtragem de elementos. III - In Ruhig Fliessender Bewegung [com um movimento calmo e fluente]: Ressurreição ${ }^{79}$.

\subsection{Arranjo}

É verdade que um arranjo utiliza uma música como material, mas não como uma colagem musical utiliza. Essa música não é outra senão a mesma; o arranjo não se individualiza. Assim, há uma manutenção do estatuto de obra, enquanto a ela é permitido diversidade em diferentes arranjos, manifestações dos seus possíveis. São novas visões e leituras, mas que se subordinam à obra. Ou há a manutenção da ideia de essência, isto é, de que a essência da obra foi mantida, enquanto tudo o que era inessencial foi mudado; ou a referência à obra de origem é tão forte e dominadora que há uma subsunção: o arranjo não escapa da obra da qual é um arranjo, da autoridade de sua obra - é apenas um arranjo, incapaz de se individualizar, de sustentar-se por si.

Obviamente a ideia de arranjo pode ser colocada em questão de diversas formas. Em 5 Programmings of a MIDI-Keyboard - 5. Universität der toten Philosophen (2006) [5 Programações de um Teclado-MIDI - 5. Universidade dos Filósofos Mortos], Johannes Kreidler toca, seguindo corretamente a partitura, o último contraponto da Arte da Fuga (cerca de 1750) de Bach em um teclado MIDI. Entretanto, o som de cada nota é produzido apenas quando a nota é solta, depois de pressionada, desconstruindo assim a relação causal mecânica presente em instrumentos de teclado não-eletrônicos, nos quais o som é produzido normalmente logo após o músico pressionar a tecla. A obra de Bach é de fato executada. O novo arranjo escolhe um instrumento que permite desconstruir a relação causal normalmente imbricada na execução de obras para teclado. A obra consiste nesse deslocamento, enfatizado pela operação de arranjo, que permite comparar o antes e o depois (o original e o arranjado).

79 In Ruhig Fliessender Bewegung é o nome do terceiro movimento da segunda sinfonia de Mahler. A sinfonia é chamada, por vezes, de Sinfonia A Ressurreição. 
Arranjos podem então ser utilizados enquanto técnica, para criar um distanciamento com o original, sem no entanto separar-se deste. John Oswald explora essa característica designando a cada tecla de um teclado-amostrador [sampler keyboard] um timbre/fonte sonora diferente, mas que mantém a nota correspondente do teclado. Em Prelude (1990), grava uma interpretação (realizada por um computador) de um prelúdio de Lizst neste teclado. O resultado é uma radicalização da técnica nomeada por Schoenberg de klangfarbenmelodie [melodia de timbres ou de matizes de som], a qual Oswald chama de klangprobes [sondas-sonoras] (OSWALD, 2001, p. 33). Além das diferenças de fontes sonoras, por tratar-se de um exemplo de sampleamento, temos como possibilidade a inclusão de toda gama de diferenças específicas aos processos de fonografia embutidas nesse tipo de orquestração ${ }^{80}$. No exemplo de Oswald, entretanto, não é possível reconhecer o prelúdio de Lizst (e qual prelúdio especificamente): a técnica de arranjar para outros sons gera um resultado sonoro que, por um lado, obedece a partitura e, por outro, é bastante díspar e não mantém as identidades sonoras da obra original. Novamente, um caso de arranjo que propositalmente falha em conservar a identidade da peça arranjada é um expediente para a criação de obras derivadas, que guardam em seu processo o fato de serem arranjos, mas não em seu resultado sonoro.

O arranjo pode ser utilizado para gerar uma camada de distanciamento para com o original. Pode citar a música original, sem exatamente contê-la; pode, mais humildemente, conter seu traço identitário. Em I Still Haven't Found What I am Looking For - Special Edit Radio Mix (1991), do grupo Negativland, é realizado um arranjo da música I Still Haven't Found What I am Looking For (lançada em 1987), do grupo U2. Os sons utilizados são timbres eletrônicos pouco complexos, que lembram timbres usados em videojogos da época, que dão um tom de paródia à música e ajudam a desconstruir qualquer credibilidade possível da mensagem da canção do U2 (busca religiosa, procura pelo sentido (último?) das coisas ${ }^{81}$ ).

De resto, o que foi aqui dito sobre arranjo deve valer para o remix, com a diferença do remix ser um arranjo focado em mudanças que, por um lado, envolvem mais diretamente processos de fonografia (mixagem, equalização), e por outro, historicamente, costumam indicar a colocação de batidas típicas de músicas eletrônicas de pista em músicas que não as tinham originalmente. Ademais, boa parte das práticas de remix,

81 A letra narra diversos episódios nos quais o protagonista ainda está a procurar, ainda não achou aquilo que procura. 
incluindo o dub, envolve o acesso às gravações originárias, às faixas separadas, anteriores ao processo de mixagem e masterização [às master tracks]. Isso cria também uma vinculação de permissões: a tais artistas foram permitidos pelo detentor dessas gravações fazer um remix; há então um elo, uma relação direta e clara de autoridade, do original com o derivado.

La 10ème Remix (1998), de Pierre Henry, brinca com o termo remix ao fazer um novo arranjo de sua colagem musical La Dixième Symphonie De Beethoven (1979). Além de apresentar uma nova mixagem e disposição dos elementos de La Dixième ele adiciona à música, em vários momentos, batidas dançantes e também ostinatos típicos de música dançante. Henry literalmente coloca boa parte das batidas sobre a música, isto é, como uma camada independente sobreposta aos excertos de suas mixagens de sinfonias de Beethoven. Diferentemente da grande maioria das músicas eletrônicas de pista, os andamentos das camadas diferem, o que amplia a percepção de que sejam camadas díspares. Parece implicar que remixar envolva necessariamente adicionar batidas e que a música apresenta dois modos: um em que se dança aos ritmos e sons repetitivos, outro em que se escuta a nova mixagem, o conteúdo advindo de Beethoven.

\subsection{Plágio}

Plágio implica necessariamente uma infração: algo que se supõe original e criativo, ou que se faz passar por, em verdade não o é. O plágio envolve uma reprodução que se apresenta como nova produção. Nesse sentido, o plágio invoca seu espectro: na tentativa de passar desapercebido, maquia seu mal feitio, dissimula sua apresentação enquanto plágio. Pode-se compreender assim porque dissemina, entre os que precisam identificálo, desconfiança: faz pensar que há sempre algo indevidamente copiado, utilizado; que é preciso localizar e impedir que a infração ocorra - um princípio de paranoia.

Essa paranoia pode levar a um questionamento da validade da noção de trabalho, quando há uso de obras de outrem, numa composição. No entanto não se está mais no âmbito do plágio. Oswald, em seu plunderphonics, de cara quer afastar o espectro mencionado: advoga deixar claras as fontes utilizadas e citá-las, a fim de não abrir espaço para a suposição de que algo foi maquiado, de que há plágio. Diz ele: "atos de pilhagem [plundering] devem ser flagrantes. Há um monte de furtos de amostras [samplepocketing], 
papagaiadas [parroting], plágios e roubo de melodias [tune thievery] que não são o que nós estamos fazendo" (OSWALD, 2001, p. 17).

Os Tape-Beatles, do final da década de 1980 ao início da seguinte, ao apropriaremse de inúmeras músicas e outros artefatos sonoros e não declararem as fontes de seu material de trabalho, poderiam ser acusados de plágio, mas não John Oswald com os plunderphonics. A essa acusação os Tape-Beatles possivelmente responderiam: trata-se de Plagiarism® - a recontextualização de obras alheias constitui autoria (KELLY, 1991). Muitos anos antes, Darius Milhaud, na sua suíte para orquestra Le Boeuf sur le Toit (1919), fora acusado de plágio. Apesar de sua apreciação declarada pelo compositor Marcelo Tupinambá, e a inclusão de sete de suas músicas, nas 28 utilizadas na suíte, Milhaud aparentemente nunca citou as fontes usadas. Diz ele, em 1949: "Ainda perseguido pelas lembranças do Brasil, eu juntei algumas poucas melodias populares, tangos, maxixes, sambas, e até um fado português, e os transcrevi com um tema de rondó recorrente entre cada par sucessivo." (MILHAUD, apud THOMPSON, 2002) E antes disso, em 1944, descreve a colagem como advinda de "músicas folclóricas brasileiras" (idem). Não por acaso o musicólogo brasileiro Baptista Siqueira irá escrever a obra como plágio, uma usurpação (THOMPSON, 2003).

Daí vê-se o potencial do plágio, enquanto conceito: lançar uma dúvida quanto à validade da citação e da colagem musical. Não seriam essas justificativas um modo de legitimação que, no fundo, tem a função de esconder, em negativo, ao abertamente mostrar, o fato de que algo está sendo copiado, pilhado, abusado? Aí já se está surdo à criação e à cultura, com sua história de apropriações diversas. E ficam as questões: qual a função dessa dúvida? A quais interesses ela melhor serve? Quem ela prejudicaria e quem ela beneficiaria? Por que não formular, ao contrário, o que é a originalidade senão plágio não detectado? ${ }^{82}$

Pilhar sons não constitui plágio; compartilhar arquivos não constitui pirataria ${ }^{83}$. Tive a experiência de presenciar um caso de plágio acidental, não intencional, durante o VIII Encontro Nacional de Compositores Universitários, em Goiânia, na Universidade Federal de Goiânia (UFG), no dia 25 de outubro de 2010. Era um concerto, e peças eletroacústicas de diversos compositores estavam programadas, incluindo a obra $O R e i$ dos campos de beterraba (sonata tan-sá) (2010), da série parcerias de Guilherme

82 Paráfrase de William Ralph Inge, apud THOMPSON, 2003.

83 Para uma ação poder ser corretamente qualificada como pirataria, deve envolver a venda ou exploração comercial de algo sem permissão. 
Rebecchi, que não estava presente na ocasião. A peça supostamente criada por Rebecchi consistia em uma gravação do primeiro movimento da Sonata para piano No. 14, op. 27 No.2 (1801), de Beethoven, sem nenhuma alteração aparente, a não ser talvez uma pequenina falha digital a soar no meio da reprodução. Discussões seguiram, indagando se esta era mesmo a peça, ou seja, se a peça consistia em única e obtusamente plagiar Beethoven e o pianista que gravou a sonata, deslocando o local de execução da gravação, de uma escuta em um ambiente particular para a escuta em um auditório público, por ocasião de um concerto de música eletroacústica; ou ainda se havia ocorrido alguma falha ou engano. Victor Valentim, encarregado da montagem do concerto e difusão da obra, alegou que Rebecchi havia enviado para ele aquele arquivo. A obra trazia uma nota de programa enigmática: "Nesta série, parcerias aparentemente impossíveis são forjadas por um terceiro agente" (Informação pessoal) ${ }^{84}$. Apenas depois do ocorrido foi esclarecido que Laiana Oliveira, principal organizadora do evento, havia recebido, via internet, o arquivo correto, diferente daquele difundido.

De qualquer forma, que plagiador utilizaria um exemplo tão conhecido, tão desmascarador, a não ser para colocar em jogo, acidentalmente ou não, uma série de deslocamentos: gravação como música eletroacústica, reprodução como difusão, composição como recontextualização? A obra original, por seu lado, corresponde à nota de programa enviada: trata-se de um excerto de cerca de 43 segundos de uma gravação de uma canção, por Roberto Carlos, cujos últimos segundos foram modificados colocando um decrescendo [fadeout]. O terceiro agente é o título, que dá a entender haver uma mistura de Beethoven [Campo das Beterrabas] com Roberto Carlos, dado que a canção começa com arpejos ao piano que lembram a sonata ao luar. A parceria, no entanto, não ocorre, a não ser na imaginação daqueles levados a estabelecê-la pelo título, a suspeitar que aqueles acordes vieram de Beethoven. O compositor, no caso da peça correta, articula o plágio como suspeita. Articula a colaboração virtual entre os dois artistas como o traçado de trajetórias de intermusicalidade, pelo ouvinte; de possíveis relações de apropriação. A peça não se evidencia enquanto plágio, entretanto, pela sua curta duração e decrescendo - a peça é uma ideia articulada por seu título e por aquele fragmento sonoro. Uma vez estabelecida a ideia, uma duração suficiente, não é mais necessário ouvir a canção de Roberto. O mesmo não poderia ser dito do movimento de sonata de Beethoven, que deixou muitos espectadores perplexos na ocasião.

84 Rebecchi, G.; Valentim, V. Mensagens recebidas por <guilherme.rk@gmail.com> e <valentim.victor@ gmail.com>. 


\subsection{Intermusicalidade}

O presente texto não trata de música como texto, no sentido dado por alguns estudiosos, de artefato cultural: um artefato cuja materialidade não é necessariamente a de um objeto físico. Isso não implica que música não possa ser tratada como texto do tipo música, nem que este texto aqui (essas palavras que compõem a dissertação), que versa sobre música, não possa ser tratado como texto do tipo texto. O ponto de vista tomado não partilha dessa inclinação a totalizar tudo como texto.

Não se trata assim de intertextualidade entre músicas, mas entre textos do tipo texto que versam sobre música, ou entre ideias e interpretações acerca e sobre a música. Trata-se de intermusicalidade, entre músicas. Tal qual o pensamento da intertextualidade não apenas engloba várias práticas, mas fornece uma visão sobre a textualidade, o termo intermusicalidade abarca o todo das relações entre músicas.

Dir-se-á então que onde há música há intermusicalidade, dado que, uma vez tomada como música, uma música se relaciona de imediato com ser tomada como música, e é possível ver nisso um elo entre todas as músicas (são elementos do mesmo domínio). Essa ação, tomar como música, pode ser uma compreensão, sem ainda ser conhecimento. Mas também há muitas outras inter-relações possíveis, como entre todas as músicas enquadradas dentro de um gênero, e também relações de alusão e citação, e do ponto de vista dos materiais envolvidos no processo de produção das músicas, de sampleamento e colagem musical. Mesmo a formulação extrema e possivelmente abstrata de um antigênero, como a estipulada quanto à música experimental, sofre de necessárias intermusicalidades - a partir da constituição de negativos, não encaixes e não demarcações.

Os termos arranjo, colagem, citação e plágio foram circunscritos, a fim de estabelecer categorias. Essas categorias traçam diferentes modos de tratar a intermusicalidade. Assim, em casos que se furtam a relações de referencialidade entre músicas, justamente o que é notado é a possibilidade de também ser assim; de usar músicas como material sem se referir a este, nem aparentar tratar-se de uma colagem. Nota-se isso, justamente, a partir de um referencial; aquele do conjunto das relações possíveis entre as músicas. 


\section{Capítulo 3: Referencialidade}

Este capítulo explora a noção de referencialidade, no que ela concerne às músicas incluídas nesse estudo. Tendo a referencialidade como importante fator composicional, nesse contexto, é necessário investigar o que a possibilita (o reconhecimento das fontes musicais?) e o que ela possibilita (rememorações, apreensões conceituais, argumentos, confrontos, deslocamentos da escuta?). Também é preciso, como em outras ocasiões, traçar um negativo: como escapar à referencialidade, mesmo usando músicas de outrem? Isto é, não tê-la como um destino que se desdobraria do material escolhido - das amostras musicais - e arrastaria as próprias obras. A colagem musical, divorciada da referencialidade, pressuporia que houve casamento. Isso e as condições desse movimento de arraste dependem de uma colocação da referencialidade em relação ao musical, da referencialidade como uma espécie de fora da musicalidade e, consequentemente, da colagem como algo disruptivo à estabilidade dessa linguagem musical.

Durante essa exposição explorarei aspectos caros à formulação da questão: a familiaridade, a possibilidade de uma música realizar comentários, e os possíveis deslocamentos de percepção e autoria. Com isso, abordo relações: do ouvinte com o reconhecimento; da obra com sua rede de significados; do autor com o material composicional.

\subsection{Extrarreferencial}

Quando digo referencialidade deixo implícito que se trata de uma extrarreferencialidade, em contraste com a autorreferencialidade da chamada linguagem musical. Já aí são traçados dois interiores para as músicas (obras e performances musicais). Um é formado pelo acontecimento: a música acontecendo, com suas especificidades e contexto. O outro, a linguagem musical, no qual autorreferências não são referências propriamente ditas: são os próprios elementos ordenados, dispostos; são configurações que apontam para si mesmas e para a linguagem. Uma linguagem própria ao fazer específico. Um fundo que toma forma a cada música e que é compartilhável entre 
músicas, porque não lhes é próprio nem exterior a cada atualização específica.

Pergunto: nesse segundo interior, o que as configurações fazem? Elas indicam que há uma especificidade, um musical nas músicas. Também: traçam um limiar entre o que é específico e o que não é, um limiar do não-musical. Não tratam, portanto, do que é ou não música, mas daquilo que poderia the pertencer, ou não, de direito. Do não-musical, mas também daquilo que, diferentemente, é exterior à linguagem musical, que está situado fora, mas que se pode acessar: extrarreferencialidades, ou mais sucintamente, referencialidades. Elos entre as musicas e o mundo (as não-músicas), formas de apontar para fora.

No livro Teoria da Vanguarda, escrito em 1974, Peter Bürger (2008) procura resolver a relação de tensão entre duas tradições dentro do que entende por modernidade estética, no campo das artes ${ }^{85}$ : o próprio modernismo, voltado para uma estética da autonomia; e as vanguardas artísticas, preocupadas com a superação da autonomia e recondução da arte junto à práxis vital.

Essa oposição, que o autor faz objeto da elaboração teórica, é exposta a partir da seguinte construção: a progressiva institucionalização da arte, durante o modernismo, permitiu perceber e formatar a arte como instituição e subsistema social semiautônomo ${ }^{86}$; sob a égide da estética da autonomia, e rumo ao esteticismo ${ }^{87}$, a arte descolou-se da vida. Essa estética da autonomia previa um projeto: que cada arte fosse um campo específico de atuação, com uma linguagem própria, e que, portanto, poderia se desenvolver segundo suas próprias necessidades enquanto arte, daí a autonomia. Assim, essa tradição, cujos representantes máximos foram chamados de altos modernistas, acabou por enfatizar e reforçar aspectos autorreferenciais de sua produção artística. Outra tradição, contrária a essa institucionalização e separação de arte e vida, chamada pelo autor de vanguardas artísticas ${ }^{88}$, promoveram ações e atacaram o estatuto da instituição arte, mas fracassaram na tentativa de integração proposta entre arte e vida e consequente mudança do estatuto social da arte.

Tentando compreender esse fracasso Bürger identifica um movimento de

85 No texto, o autor foca seus exemplos no campo das artes visuais, não incluindo exemplos musicais.

86 Nesse contexto, semiautônomo sugere melhor o que Bürger (2008, p. 61) indica como autônomo: "Devese insistir que a autonomia designa, aqui, o modo de função [Funktionsmodus] do subsistema social arte: sua (relativa) autonomia frente às pretensões sociais de uso."

870 esteticismo, nessa formulação, transforma a "distância em relação à práxis vital em conteúdo das obras" (BÜRGER, p. 106). A definição é circular em relação ao argumento, dado que 'distanciar-se das práticas (transformadoras) da atividade humana' resulta num 'descolar-se da vida'.

88 Cabe explicitar que o autor tem em mente principalmente - ou apenas, dependendo da leitura do texto -, o dadaísmo, mas também o primeiro surrealismo, ainda "revolucionário", isto é, ligado ao comunismo. 
reinstitucionalização das vanguardas nas neovanguardas. As neovanguardas promovem a integração do gesto vanguardista ao repertório da instituição arte. Essa integração reduz desse gesto a sua potência de contestação e poder de choque: o gesto desafiador transforma-se em ou produz obra, ou parte de - a existência desta comprova a individualidade e capacidade do artista, segundo a instituição. O que existia de promessa se perde - promessa de outros modos de viver, e não apenas de outras formas de fazer arte $^{89}$. Com isso, a relativa ausência de consequência da arte na sociedade burguesa passou a ser reconhecida como princípio da arte. Também ampliou-se a gama de possibilidades artísticas, não apenas na incorporação do gesto vanguardista, mas no escancaramento do alto modernismo como apenas uma das possíveis orientações artísticas dentro das instituições e a consequente deslegitimação deste como melhor caminho a ser seguido.

Bürger traça, nessa posição, uma leitura do estado da arte no pós-guerra, uma arte pós-vanguardista, ou de vanguardas pós-utópicas - as neovanguardas. Prepara assim o terreno para as discussões posteriores sobre a arte e o pós-moderno. No que concerne esse estudo, e mesmo com a discrepância histórica entre as artes visuais e a música, existem dois pontos de interesse. Primeiro, a possibilidade de reconhecer uma tradição musical, dentro do projeto moderno, preocupada em fortalecer e firmar a música como algo específico, não apenas com especificidades próprias, mas propriamente específica, dentro das artes - uma tradição modernista, preocupada com a linguagem musical, homogeneidade material e o estabelecimento da diferenciação entre aquilo que é autorreferencial e aquilo que é extrarreferencial ${ }^{90}$. Essa manutenção de um próprio não pode ser estática: deve ser o fio condutor de um desenvolvimento; tece uma teleologia da música - práticas composicionais que atendem a um destino desconhecido mas pré-fixado enquanto tal -, um desenvolvimento. Aquilo que foi considerado disruptivo, descentralizador, que atuaria em prol do fragmentário e do extramusical, eventualmente pode ser incorporado à linguagem musical, de modo que passe a ser considerado constitutivo dela, em sua autorreferencialidade.

Segundo ponto de interesse: a incorporação de gestos e sons extramusicais e de elementos extrarreferenciais se deu sob essa base modernista mencionada, sob a ideia

89 Um bom exemplo é o comentário de Jasper Johns (apud BAILEY, 2009, pag. 98), acerca de Marcel Duchamp: "Ele declarou querer matar a arte ('para mim mesmo'), mas suas persistentes tentativas de destruir moldes de referência alteraram nosso pensar, estabeleceram novas unidades de pensamento, 'um novo pensar para aquele objeto'."

90 Uma preocupação com aquilo que seria imanente à música. 
de desenvolvimento da linguagem. De fato, as vanguardas musicais do pós-guerra ainda se orientavam por um projeto majoritariamente modernista. Em conformidade, Fernando lazzetta (2005, p. 233), no artigo Além da vanguarda musical , comenta: "os movimentos de vanguarda musical sucederam-se no período pós-guerra, mantendo forte ligação com o projeto modernista que se estabeleceu desde o início do século XX." Assim, houve sempre um empuxo rumo a um tratamento destes incorporados que pudesse musicalizálos, isto é, moldá-los de modo que eles passassem a se mostrar naquilo que teriam de especificamente musical.

Dentro desse panorama, a manutenção do dentro e fora do musical se justifica. Se ainda é preciso colocar a referencialidade como fator importante e chamar atenção para um modo um pouco menos moderno de lidar com a música e suas heteronomias, é porque essa herança do pensamento de uma especificidade 'radical' da música existe e atua. Não se trata de desconstruir o discurso da autonomia musical e mostrar que ali, onde supostamente reinava o homogêneo e o musical, havia heterogeneidade, brotavam relações e referências ao mundo (como as quartas e quintas paralelas em sonatas para piano de Mozart, que seriam chamados de caça). As ditas heteronomias são admitidas por alguns discursos modernos ${ }^{91}$. Na verdade trata-se de algo mais simples, o fato de eu ainda encontrar esse objeto - a música - aqui, construído e institucionalizado segundo essas bases. Analiso a referencialidade no plano composicional, a partir do que a música fala (quando fala): de outros ou de si mesma. E é claro, a problemática reside em aprender a entender e escutar essa fala. À escuta de um falar de si mesma foi dada bastante atenção, em detrimento de outras escutas. É nesse sentido que se pode falar de referencialidade como extrarreferencialidade.

Um músico que está a ouvir sons e reconhecer notas diz, de um som, que é um acorde composto por fá, si, ré sustenido, sol sustenido; outro diz, do mesmo, que é uma citação do acorde de Tristão e Isolda, de Wagner, em meio à Suíte Lírica (1926) de Alban Berg. O primeiro se refere a elementos da linguagem, elementos compartilhados entre inúmeras músicas; o segundo mostra um caso de extrarreferencialidade: uma música cita outra, ao incorporar um acorde famoso desta. O acorde, decerto, é composto por elementos, mas não é isso a que Berg faz referência, e sim à obra de Wagner.

Resta saber se o próprio acorde de Tristão e Isolda, por ter adquirido uma identidade - e aqui deve-se deixar de lado toda a carga extramusical operística que

91 Discussão na qual não cabe a este texto entrar. 
Wagner utiliza -, não faz referência, simplesmente ao acontecer, a seu estatuto de acorde com nome; ou seja, se ele é referencial a seu próprio nome e sua história (que por sua vez não fazem parte da linguagem musical). Penso na música Idioteque (2000), do grupo Radiohead, por lembrar que utilizaram uma sequência de quatro acordes derivada por Paul Lansky do acorde de Tristão e Isolda, em Mild und Leise (1973) (LANSKY, 2000). Pode ser que toda vez que pense em uma reminiscência de Wagner venha à minha mente a famosa frase de Woody Allen: "Toda vez que eu escuto Wagner eu tenho vontade de invadir a Polônia"92.

Uma quebra, uma reflexão tardia e outro modelo: seria a música algo a fazer e que é feito, mesmo que não se possa dizer muito do que é? Se sim, pode-se tentar constituí-la vagamente, a partir da ideia de som, da ideia de escuta. Pode-se simplesmente mostrar: isso e aquilo são músicas. E as músicas são feitas e escutadas. Pode-se analisá-las de diversas formas. O que é o referencial nessas músicas? É aquilo que, quando se vai mostrar, mostra-se outro, de fora, aquilo que não é simplesmente tautológico. Seria possível investigar se a partir desse modelo chegamos ao outro que consolida uma especificidade para a música, como uma linguagem musical e um discurso que prevê uma imanência musical? Descarta-se o assunto, porém, por ser tangencial demais ao objeto de estudo.

\subsection{Reconhecimento}

Ao trabalhar ao redor da colagem musical como prática, precisei diminuir ao máximo as chances de uma determinada peça, supostamente construída com procedimentos de colagem musical, na verdade não utilizasse nenhuma música outra como material. Algumas estratégias: tentar cruzar os exemplos explícitos (mencionando as músicas utilizadas) e implícitos (mencionando que foi feita uma colagem musical) da literatura com as músicas supostamente correspondentes; não sendo possível verificar a correspondência, devido a transformações mais radicais, confiar na literatura, ou nos compositores entrevistados e consultados. Em outros, eu mesmo poderia dizer que outra música estava sendo usada, mesmo sem precisar qual, ou ainda poderia dizer acerca do 
estilo e da aparência sonora - uma cantata de Bach, um trecho de balada pop, algo entre Wagner e Strauss, música folclórica alemã, um jingle. Seria paranoia pensar que aquilo havia sido gravado exclusivamente para a música em questão, com todos aqueles resíduos indicando o contrário ${ }^{93}$. Eu poderia de fato perscrutar mais, se necessário, mas a quantidade de exemplos confirmados, segundo minhas estratégias, bastavam ${ }^{94}$.

Uma vez determinado que uma peça utilizava procedimentos de colagem musical ainda ficava a questão, levantada de passagem e respondida negativamente no capítulo 2: seria isso suficiente para que possamos chamar uma música de colagem musical? Se a resposta é não, então há indício de um duplo uso do termo colagem musical, de forma que esse segundo uso depende da aparência da obra - como ela se apresenta aos ouvintes. É nesse momento que se dá o casamento entre colagem musical e a referencialidade. Porque uma música que é uma colagem deve parecer diferente de algum modo, e esse modo se liga à relação disruptiva, inorgânica, e que transparece um caráter fragmentário.

Com isso, não é colocado que necessariamente falte uma unidade. Essa unidade, essa consistência ou, indo mais longe, essa organicidade e continuidade, são articuladas a partir de uma aparência que evoca o contrário: uma unidade de fragmentos colados uns nos outros, um organismo costurado de pedaços de outros organismos, uma continuidade de elementos disruptivos. Mesmo não abrindo mão de um caráter de obra que se sustenta sozinha, há de se admitir que ela não pode mais ser encarada como autocontida, monádica.

Mesmo que Victor Frankenstein, personagem do famoso romance de Mary Shelley, Frankenstein, ou o Moderno Prometeu (1818), tenha criado uma criatura consciente, capaz e inteligente, de natureza dócil e articulada, ela é monstruosa, disforme e repugnante para humanos. E, no entanto, apesar de não ter um nome, pode ser nomeada chamamo-la, para homenagear seu criador, por seu sobrenome, Frankenstein ${ }^{95}$. Assim, também obedece ao império do nome, do que é possível nomear; há uma unidade, mesmo que no limite advenha apenas desse mesmo ato de nomear e da possibilidade de

93 Mesmo as inserções de trechos no estilo jingle nas músicas do Negativland, ou as mudanças de estilo em John Zorn não carregam consigo esses resíduos; estes são advindos das diferenças envolvidas nos processos de fonografia. Uma caracterização desses resíduos foi abordada no tópico 2.5.

94 No tópico 1.4 foi mencionada, ao final, a síntese concatenativa. Há também softwares que reconhecem que música está sendo tocada. Disso, há uma possível direção de pesquisa para o reconhecimento do material utilizado em determinada música - as fontes sonoras, as músicas amostradas etc.

95 Não há no romance um nome dado pela escritora para a criação do seu personagem Victor. (SHELLEY, 1994). 
receber, de acolher, de adotar, mesmo a contragosto, esse nome. A criatura era disforme, mas com uma forma especificamente disforme - uma deformação articulada em uma unidade bem formada.

Em música, essa aparência de construto, ligada ao inorgânico, levanta suspeitas que são um primeiro impulso para a noção de referencialidade: de onde vêm esses pedaços, esses sons que têm a aparência do artifício? Ora, vêm de um fazer artístico, dos atos criadores envolvidos nesse fazer, tal como todo o resto, tal como todos os sons de todas as músicas. Prometeu buscou o fogo, um símbolo para a tecnologia, a fim de dar forma aos seres humanos, que não a tinham. Diferentemente do que ocorreu aos outros animais, Epimeteu não havia fornecido aos humanos uma qualidade que lhes desse forma - eles precisavam da técnica ${ }^{96}$. Este é o motivo pelo qual Shelley deu ao seu livro o subtítulo O Moderno Prometeu - o motivo da ligação seminal entre a técnica e a existência humana. E, a partir disso, nada impediria um cientista fictício posterior, talvez em ambiente cyberpunk, de criar seres com aparência humana perfeita - um tema bem desenvolvido em O Caçador de Androides (1968), de Phillip K. Dick ${ }^{97}$. Mas dificilmente este cientista fá-lo-ia usando fragmentos humanos; talvez usasse partes mais internas ou maiores - torso, dois braços da mesma pessoa, órgãos, dois olhos etc.

De qualquer forma, a caça às criaturas está presente em ambos os casos. Esta caça é análoga à verificação da suspeita: se esse som vem de um fazer artístico, mas não é explicado por ele, então é possível que o fazer artístico consistiu, num primeiro momento, em apropriar-se de algo exterior; algo para o qual eu consiga apontar: um braço de um morto, desenterrado da cova. Num contexto japonês, vozes de locutores um homem e uma mulher -, trechos engasgados de música infantil, com muito ruído de fundo, falas estrangeiras (algum dialeto chinês), música pop entrecortada com ruídos graves, gritos com distorção: The Night Before the Death of the Sampling Virus (1993) ["A Noite Anterior à Morte do Virus do Sampleamento"], de Otomo Yoshihide. São 77 amostras autocontidas, pedaços que se apresentam como tal, fragmentos sem transição, loops arbitrários ${ }^{98}$ - um CD a ser tocado pelo ouvinte em ordem randômica, em mais de um aparelho reprodutor ao mesmo tempo. "Memórias sem um cérebro" (YOSHIHIDE, 1995, p. 10) procurando um local para se instalar, para dar-Ihes consistência, procurando ouvintes que possam ressoar lembranças, traçar conexões.

96 Essa leitura é exposta por Bernard Stiegler, no início do filme já citado, The Ister (BARISON, 2004).

97 O título original do romance é Do Androids dream of Electric Sheep?.

98 O loop é dito arbitrário quando o som que sofre o processo de repetição aparenta não ser respeitado, quanto a suas características, quanto ao ponto de início e/ou fim do loop. 
Mas não é preciso que uma música mostre, ainda mais tão enfaticamente, ser constituída de fragmentos, partes destacáveis, recombináveis, sobreponíveis. Que a música ou o corpo possam ser vistos como formados a partir de inúmeras partes conjugadas alimenta a suspeita; se há partes e não apenas o todo, podem ter sido importadas de outros: este meu braço (aponto para ele, levanto ele) está conjugado organicamente ao resto do meu corpo, eu espero! Já o gesto de piano que intervem nas bases repetitivas de Alterstill (Nothing is Sacred) (1993-4), de John Wall, talvez venham de alguma obra do repertório contemporâneo pós-segunda guerra, mas não há como afirmar.

O uso de colagens musicais traz esse movimento: se a colagem é notada enquanto tal, então carrega uma memória, formada pelos traços de autoria e obra. Mesmo que não seja possível decifrar as marcas que ela carrega, é o bastante para impedir uma integração perfeitamente orgânica ao resto da música. Nesse caso o procedimento usado arrasta a música em direção a uma certa equivalência entre processo e resultado: ambos colagens musicais.

Mas há maneiras de fugir a esse movimento de arraste. À pergunta "há referência mesmo quando não há reconhecimento de que se faz uma referência?", a resposta: se a suspeita se mantiver viva, é melhor investigar (tal qual Rick Deckard no referido livro de Dick). No entanto, há limites em que as coisas são eventualmente indistinguíveis ou irreconhecíveis. Por isso, investigar-se-á os limites de reconhecibilidade auditiva.

Antes, um exemplo: já foi descrito, no tópico 1.4, o procedimento utilizado na música Solo for Wounded CD (1995), de Yasunao Tone. A peça pode, como fiz algumas vezes, antes de pesquisar a respeito, ser escutada como não referencial - uma série bastante idiossincrática de barulhos bastante intensos, de aspecto digital, cada um sujeito a um número aparentemente aleatório de repetições - barulhos que seguem um a outro com ritmos e durações de máquina quebrada. Nela há pausas súbitas, sem função dramática, e trechos em que só um dos canais funciona, pequenas idas e vindas de barulhos, como se uma frase, já em si estranhamente fragmentada, fosse lida com hesitação, voltando para resgatar uma continuidade não mais possível, retornando, perdendo trechos, parando, prosseguindo. Não há condução temporal. Entre a parte I e a parte II não há nenhuma mudança especialmente pronunciada de condução: parece a mesma música, dividida arbitrariamente em duas partes que duram uma quantidade de tempo arbitrária, mas suficientemente longa para dar-Ihes consistência. 
Aí existiria uma metáfora - a das máquinas quebradas. Seria exagero dizer que a música faz referência a máquinas quebradas - uma frase da linguagem ordinária como "duração de máquinas quebradas" poderia ser mais precisa com um estudo dos padrões de repetição, permanência e mudança dos sons da peça. Ademais, seria uma forma de aproximação, com elementos familiares, com palavras e ideias que são familiares, da música, de seus desafios. Da mesma forma, ao ouvir inovações sonoras como as de Pression (1969-70), peça para violoncelo solo de Helmut Lachenmann, usa-se às vezes, como ponto de apoio inicial para uma escuta desfamiliarizada, comparações com portas rangendo, serralharias, casas de madeira abandonadas no frio, rangendo etc. Esse ponto de apoio inicial e esse jogo de imagens criadas para apoiar a escuta mais têm a ver com a dificuldade de entrar no espaço da obra (seu espaço autônomo) - o que leva à observação de fora, distante, a partir do mundo das coisas (de fora da música) - do que com alguém que, de dentro, observa indicações apontando para fora. Essa ideia pode parecer problemática, mas é justamente essa natureza que permeia todas as considerações sobre referencialidade.

Tone é conhecido, dentre outras coisas, por usar como instrumentário toca-CDs contendo CDs preparados - CDs que impedem uma correta leitura da informação neles gravadas. Como instrumento preparado, esse tipo de instrumentário tem certas características. No caso, os saltos, ruídos, repetições e truncamentos descritos acima são, em boa parte, resultado direto do que o instrumentário faz com o som - o característico som skip [salto] de CD marca a peça inteira. Não obstante, seria no mínimo apressado inferir disso que a obra tenha a máquina quebrada, ou o funcionamento da máquina e da maquinaria digital como foco extrarreferencial, simplesmente por utilizá-los. O violoncelo evocado a partir de seu som é um instrumento musical. Será que aprende-se a usar a palavra violoncelo para fazer referência ao timbre característico que dele provém, como também se fala de Dimos Goudarolis ao timbre específico de violoncelo (provavelmente de sua gravação das Suítes de Bach ${ }^{99}$ ). O toca-CDs não é um equipamento de produção de música, e também o CD? Assim como os sons de Pression ou mesmo o som bastante ruidoso de uma arcada de Goudarolis na citada gravação não são sons comumente feitos por um estudante de violoncelo, aqueles produzidos por Tone não são comuns para quem escuta música em casa, através de seus aparelhos de CD. Da mesma forma que um skip é encarado como falha, dentro do contexto de reprodução

99 Goudarolis (2011). Nesta gravação, a interpretação das seis suítes para violoncelo solo de Bach segue indicações do manuscrito de Anna Magdalena Bach. 
transparente do som gravado, as arcadas ruidosas também são falhas no contexto de execução limpa e impessoal de uma obra para violoncelo. Ademais, o uso de Goudarolis das arcadas indicadas por Anna Magdalena Bach não é uma referência à prática interpretativa da época de Magdalena; ela é parte da prática de Dimos. O mesmo vale para Tone. Os ruídos causados pelos CDs preparados não são incidentais - eles não são a informação que deve ser resgatada da experiência; eles são boa parte do que se deve experienciar durante a música.

Poder-se-ia objetar que a lógica de um violoncelo é do tipo com o qual o usuário deve trabalhar, enquanto a de um toca-CDs é algo que faz o trabalho para o usuário. Assim, os erros produzidos pelo usuário, no primeiro tipo, seriam resultantes de uma prática, enquanto os produzidos pela máquina, no segundo tipo, seriam referentes ao seu mal funcionamento (como uma nota do lobo [wolfton], uma vez reconhecida, traz como referente um funcionamento aberrante do instrumento de corda). Essa objeção, no entanto, desconsidera o fato de que Tone utiliza o toca-CDs com o primeiro tipo de operação exposto, isto é, trabalha com a ferramenta-instrumento toca-CDs. O aparelho resiste a suas investidas, e é preciso que ele desenvolva uma técnica para operá-lo de maneira musicalmente instigante. Como preparar os CDs? Até que ponto pode-se aplicar fitas adesivas a eles, até que ponto soa o conteúdo gravado ou os ruídos de falhas de leitura? Entretanto o próprio compositor tem também como intenção que o aparelho provoque ele mesmo acidentes sonoros interessantes, que promova a imprevisibilidade da performance musical; isto é, que ele faça o trabalho para o compositor.

Há assim uma exploração do entremeio: as falhas apontam para a musicalização uma expressividade musical própria - daquilo tomado como simples meio tecnológico transparente. Esse processo - musicalizar o mundo - foi realizado extensivamente por diversos artistas. Referencialidade? Sim, no momento em que se percebe a aproximação, a operação, o deslocamento de uma máquina, um objeto, um som não-musical para dentro da esfera do musical. No momento em que a esfera acolhe esse deslocamento; em que ele é uma possibilidade, e no limite uma potência que reside em tudo, um virtual esperando atualização. Momento do discurso, de uma política da sensibilidade: podemos musicar o mundo, basta fazer isto e aquilo. Mas também não: aquilo é para ser experienciado como música; tem uma duração, uma presença material, não foi colocado para ser apreendido como nformação. Não são processos que caracterizariam o ideal da peça conceitual. Não é reforçado o caráter de autoanulação quanto ao conteúdo 
experiencial, que teria como função dar mais espaço a um conceito que seria objeto de reflexão posterior.

Adiciona-se aqui o fato de a obra ter como material duas outras obras, gravadas em CDs então preparados por Tone. Para os familiarizados com Jiao Liao Fruits e Solar Eclipse in October há uma outra camada semântica. Imagens foram traduzidas digitalmente, de forma a resultar em sons. Nessas obras existem duas distinções importantes: os objetos musicais seguem um ao outro, como uma coleção que é apresentada, peça por peça, ao ouvinte (como imagens que seguem umas às outras); os sons que formam esses objetos são ruídos digitais agressivos, sem espaço acústico interno (sem mediação, na gravação, de um espaço que se manifeste acusticamente), mas todos com certa unidade morfológica.

Em suma, em Solo for Wounded $C D$ há uma desconstrução destas duas obras, face a uma expressividade maquinal (de ruídos adicionais, de rompimento da apresentação linear de outrora, de gaguejos e emperrares), preparada ou ainda desvelada pelo próprio compositor. Pois é na possibilidade da técnica de ser explorada e dela advir uma poética que se revela seu outro lado. Referencialidade? O mesmo esquema segue: de imagens a sons e à composição de Musica Iconologos, à reapresentação desconstruída dessa face à musicalização do toca-CDs, em uma versão, que é também algo novo. No final, a experiência de Solo for Wounded CD como uma música autocontida, uma experiência não muito analítica e racional, e a imersão nos seus aproximados 48 minutos, faz-me suspeitar de que eu esteja já a realizar o trabalho do arqueólogo. Talvez seja melhor retirar a pergunta. Basta colocar o outro lado: a possibilidade da poética ser perscrutada a fim de revelar a técnica que a coloca em funcionamento.

Curtis Roads, em Microsound (2004), elenca nove escalas temporais a fim de propor uma tipologia, e estipular que a percepção humana processaria cada uma destas escalas diferentemente. Interessam-me as de duração intermediária:

2. Supra: uma escala temporal além daquela à qual pertence uma composição individual, se estendendo por meses, anos, décadas e séculos.

3. Macro: a escala temporal da arquitetura ou forma musical, medida em minutos ou horas, ou em casos extremos, em dias. 
4. Meso: divisões da forma. Agrupamentos de objetos sonoros em hierarquias de estruturas de frase de variados tamanhos, medida em minutos ou segundos.

5. Do Objeto Sonoro: uma unidade básica da estrutura musical, generalizando o conceito tradicional de nota para incluir eventos sonoros complexos e em mutação, em uma escala temporal abrangendo de uma fração de segundo a vários segundos.

6. Micro: partículas sonoras em uma escala temporal que ultrapassa (para menos) o limiar da percepção auditiva (medida em milésimos de segundo ou milisegundos).

7. Da Amostra: O nível atômico dos sistemas de áudio digital: amostras individuais binárias ou valores numéricos de amplitude, um seguindo o outro em um intervalo de tempo fixado. O período entre duas amostras é medido em milionésimos de segundo (microssegundos). (ROADS, 2004, p. 3-4).

A partir dessa definição, é possível abordar a questão do reconhecimento. Ao operar procedimentos de colagem musical em escalas temporais de dimensões menores (quanto à medida de duração), há uma passagem em que os materiais perdem sua identidade. Sem identidade não há possibilidade de reconhecimento, e então não há possibilidade de referenciar a música utilizada pelo som. Ora, se na Escala Temporal do Objeto Sonoro há uma "unidade básica da estrutura musical" é porque ela permite a configuração de identidades, justamente de objetos. Assim, se este objeto estiver em um contexto que indique ter sido retirado de outra música, ou possuir uma marca sonora suficientemente forte, pode ser tomado como referencial da música da qual adveio (mesmo que a própria música não possa ser identificada). Diz-se que algo referencia sem referente da mesma forma que alguém aponta para fora, mas não particularmente para algo - um gesto bem definido, embora de execução vaga ou não confiável quanto ao alvo.

Esse ser tomado como referencial indica ser possível relacionar o som com certas informações disponíveis ou formuláveis, de modo a estabelecer um elo entre a informação e o som. Um fragmento de música, com uma duração da escala do objeto sonoro, tem, para aqueles que conhecem a fonte e aqueles que têm as informações sobre ela, um duplo caráter de presença e indicação. Presença do fragmento, indicação de que há toda uma música, uma obra não presente, ou ainda: presença do fragmento, indicação de que o contexto de aparição é agora outro; presença do fragmento, mas com a indicação de que se encontra transfigurado. 
Ao diminuir as durações em direção à escala temporal Da Amostra, passando pela escala Micro, o reconhecimento da independência de cada fragmento é impossibilitado. Partículas sonoras são agrupadas pela percepção e passam a configurar texturas e objetos sonoros formados por aglomerados de fragmentos. A identidade é atribuída ao conjunto, e assim, por não poder separar as partes, em meio ao percebido, não é possível estabelecer elos através da escuta. Ao se operar na escala Da Amostra não há mais som, mas apenas abstrações (a escala não é mais uma escala de percepção, propriamente dita, mas aquela na qual a percepção já não mais penetra; na qual entra-se apenas pelo pensamento e opera-se com softwares).

Portanto, o objeto sonoro, para se caracterizar como tal, segundo as implicações da definição da escala temporal 5, precisa ser compreendido como unidade, de identidade possível de se estabelecer; um evento sonoro destacável. A definição da escala Meso depende dessas identidades para configurar agrupamentos e hierarquias. Por sua vez, a escala temporal Micro se apoia justamente na dificuldade ou impossibilidade da percepção de unidade identitária; quando se sucedem, as partículas sonoras têm duração curta demais para poderem ser ouvidas individualmente, e assim, dão a sensação de continuidade sonora, configurando gestos maiores (pertencentes às escalas do Objeto Sonoro e/ou Meso). Entre as escalas Micro e do Objeto Sonoro há uma zona de incertezas, de difícil e variada categorização, onde já existem processos de individualização dos sons, mas as identidades percebidas não são ainda suficientemente fortes.

Velocity (1993), décima segunda e última parte da obra Plexure, de John Oswald; O Chá (2004), de Mário Del Nunzio, e Product Placements (2008), de Johannes Kreidler têm certas similaridades: curta duração (aproximadamente 33 segundos para a peça de Kreidler, 58 para a de Del Nunzio e 72 para a de Oswald); as três utilizam amostras advindas de outras músicas como elementos composicionais; essas amostras são de pequena duração, variando entre a configuração de um gesto e a de uma partícula sonora, componente de um som/gesto mais longo; há grande predominância de montagem das sequências musicais partindo da justaposição das amostras, tornando possível pensar o fluxo temporal como a velocidade na qual as amostras se sucedem. São peças que se adequam ao escopo da pesquisa.

Diferem especialmente na forma com que estabelecem relações de reconhecibilidade para com as músicas das quais foram retiradas as amostras; o modo 
como tratam a referencialidade e a finalidade do uso de práticas de colagem musical; como articulam aspectos formais e perceptivos, a partir de modos específicos de lidar com as amostras; como articulam aspectos temporais ligados à noção de escalas temporais.

Velocity [Velocidade] foi lançada em CD em 1993. Seus 71.8 segundos podem ser divididos em duas partes, denominadas pelo compositor Tremendous (do início até 36.47 segundos) e Tremulous (desse ponto até o final). Para compor Plexure, Oswald preparou um banco de amostras retiradas de centenas de gravações de músicas de sucesso comercial, lançadas entre 1982 e 1992 (com algumas exceções: gravações lançadas anteriormente, mas que não destoavam das outras). As músicas foram escolhidas de acordo com estatísticas de venda, colocações na pontuação da revista Billboard e capacidade de evocar a noção de gancho (por ora um sentimento de grande familiaridade, a ser comentado com mais detalhes ainda neste capítulo). Para o autor, esse banco de amostras representaria sonoramente a primeira década da era do CD (na escala Supra, situando a peça no mesmo período que a de Del Nunzio, mas não de Kreidler, que não opera com CDs).

Os trechos musicais desse banco foram então ordenados, com a ajuda de Phil Strong, do mais lento ao mais rápido, em termos de andamento. Essa catalogação do andamento de cada trecho se tornou um fator primordial para a estruturação da peça (OSWALD, 2000, p. 15).

Antes de configurar objetos sonoros várias amostras foram combinadas com outras, mixadas e alteradas espectralmente (através do uso de filtros e também de efeitos de metamorfose espectral - de um conteúdo espectral a outro). Essas operações tiveram como objetivo tornar menos óbvio (ou fácil) o reconhecimento das fontes musicais de cada amostra, além de indicar similaridades entre as músicas amostradas. A obra seria capaz de acionar o maior número de ganchos possíveis, além de estabelecer uma relação reflexiva e crítica em relação à alta similaridade das músicas utilizadas. $A$ partir dessas concepções, o trabalho de montagem da peça procurou apontar para a criação de uma rede hipertextual de relações musicais entre as amostras usadas (OSWALD, 2000, p. 14). Similaridades gestuais, rítmicas e timbrísticas são usadas para promover o encadeamento entre objetos sonoros; a velocidade com que passam as amostras e a quantidade de amostras contribuem para criar uma sobrecarga no ouvinte, a reconhecer e tentar identificar as fontes musicais utilizadas. 
Em Velocity, além do andamento é importante a taxa de sucessão dos objetos sonoros. Após articulação de um glissando de guitarra, ao final de Tremendous, o andamento das amostras utilizadas se torna mais rápido, o que indica o começo da seção Tremulous. O que se sucede é um grande gesto de acelerando, que age sobre a taxa de sucessão dos objetos sonoros, até que, próximo a 56 segundos, ocorra uma transição em que a sucessão começa a operar na escala temporal Micro; as amostras se aglutinam e passam a cada vez mais fazer parte de uma textura sonora comum, até se tornarem partículas sonoras indiferenciáveis ao final da peça. Esse movimento é acompanhado por uma predominância de sons rítmicos que remetem à instrumentalidade de uma bateria, motor rítmico da maioria das músicas amostradas.

O Chá, de Mário Del Nunzio, foi criada em 2004, inicialmente como trilha para a dança homônima de Melina Scialom. Foi apresentada em diversos concertos de música eletroacústica e posteriormente lançada como faixa no álbum virtual Música Eletrônica 2004 (DEL NUNZIO, 2009). Seus 58.053 segundos podem ser subdivididos em três seções, separadas por pausas, compreendendo a apresentação do material composicional (do início até a primeira pausa, em 8.144 segundos), e os dois desenvolvimentos, nos quais esse material sofre diversas transformações (desconstrução e remontagem da sequência, aplicação de reverberação, expansões temporais, filtros ressonantes etc (os momentos iniciam-se em 9.963 e 36.78 segundos)).

Ao ser entrevistado, o compositor declarou que a primeira parte da peça foi construída a partir de amostras de um a dois segundos, retiradas de CDs de sua coleção pessoal. Essas amostras foram numeradas e então ressequenciadas (a quantidade permanece incerta, entre 30 e 60, provavelmente). A partir dessa nova sequência aplicouse um processo no qual estabeleciam-se as durações, tratamentos de equalização e panorâmico para essas amostras, então justapostas. No campo das durações, seguindo a sequência (início da peça), de $10 \mathrm{~ms}$, as amostras tendem a aumentar progressivamente seu tamanho, até atingirem $38 \mathrm{~ms}$. O tratamento panorâmico sempre se faz de um lado ao outro do campo estéreo; nas primeiras amostras percorre os extremos (da direita para a esquerda e vice-versa). Progressivamente esse movimento se torna menor, em média, e o panorâmico, mais centralizado.

O compositor intencionalmente tornou impossível a reconhecibilidade de qualquer fonte musical, operando com amostras no âmbito da escala temporal Micro (10 a 38ms). Sua duração curta, somado o fato de se sucederem uma após a outra, faz com que as 
amostras formem um único gesto/textura de aproximadamente 8 segundos (denominado anteriormente apresentação do material composicional), pertencente às escalas temporais do Objeto Sonoro e Meso (dependendo da escuta agrupam-se objetos sonoros intermediários, o que no entanto não invalida a visão desse gesto como objeto sonoro e primeira parte da forma da peça). Desse modo, a peça não opera utilizando relações declaradas de familiaridade.

Essa postura em relação à colagem musical faz com que as fontes utilizadas não sejam identificáveis. Segundo Del Nunzio, a partir da estruturação de caráter abstrato e autossuficiente da peça, "quaisquer que fossem as amostras utilizadas, a diferença de resultado ia ser, aparentemente, irrelevante" (informação pessoal ${ }^{100}$ ). Embora esse discurso enquadre os sons como de fontes irrelevantes, as amostras não são tratadas propriamente como material sonoro/composicional pelo autor: são apenas sons convenientes, disponíveis, ao fácil alcance, que ele utiliza para criar o material da peça (ou seja, as amostras não se diferenciam por suas qualidades sonoras específicas). Além disso, não é certo que a coleção específica de CDs utilizada pelo autor, em sua heterogeneidade, não tenha de fato relação com o resultado sonoro (isto é, uma vez que se tenha conhecimento da proveniência dos sons, não é realmente certo que as fontes sejam irrelevantes).

Johannes Kreidler compôs Product Placements [Publicidade Indireta/embutida] em 2008. Em seus 33.74 segundos a peça utiliza 70.200 amostras de músicas. Para cada uma das amostras o compositor preencheu um formulário de autorização de uso, agindo de acordo com a legislação alemã. No dia 12 de setembro de 2008 Kreidler entregou a documentação na agência de regulamentação GEMA (KREIDLER, 2008).

Product Placements foi pensada como parte da obra conceitual e performance homônima (Kreidler menciona se tratar de uma "obra teatral multimídia"), cuja intenção era provocar uma discussão acerca do futuro das leis de direitos autorais na Alemanha e a relação entre uso criativo e compensação financeira, no que concerne a música, durante a era digital. Os formulários eram pedaços de papel, várias resmas, fastidiosamente preenchidas - o que poderia ser evitado se o sistema fosse computadorizado. Ademais, a agência demoraria meses para analisar a viabilidade e condições de legalidade da obra de Kreidler, atravancando a análise de várias outras obras. Por outro lado, não há como facilmente garantir - se é que há como garantir - que o 
compositor tenha de fato utilizado amostras musicais derivadas das músicas declaradas, o que torna a tarefa quixotesca - um símbolo para as tentativas de controle de colagens musicais na era da internet. As milhares de amostras seriam um símbolo para os milhões de músicas disponíveis na internet, enquanto os 33 segundos seriam simbólicos para as possibilidades de compressão e compactação de informação, existentes com as novas tecnologias digitais.

Formalmente, Product Placements alterna articulações (envolvendo as amostras) nas escalas do Objeto Sonoro e Micro; traça, segundo o compositor, dois arcos e uma coda; em aproximadamente 10,5 segundos começa o segundo arco, em 25.8 segundos a coda (informação pessoal $\left.{ }^{101}\right)^{102}$. Começa encadeando amostras curtas (entre 70 e $80 \mathrm{~ms} \mathrm{e}$ de duração cada vez maior) que se agrupam perceptivamente em um objeto sonoro quando há silêncio (por exemplo, do início até 0.9s). Em 3.96s um som contínuo surge, sobreposto, articulando um gesto de crescendo acompanhado pela camada inicial. As amostras, justapostas, durando até cerca de $120 \mathrm{~ms}$, podem ser percebidas separadamente, mas com certa ambiguidade. Em 6.45s, atingido um clímax de intensidade, a peça inicia sua segunda parte, que segue até 10.44s, explorando justaposições de amostras de duração mínima (cujo resultado se assemelha a sons de ruídos de teste, como o ruído marrom). Nesse ponto é esboçado um jogo de alternâncias entre amostras com características harmônicas e amostras ruidosas, para rapidamente dar lugar a um novo gesto de crescendo, em 13.217s. Essa mudança de foco é articulada pela pontuação rítmica de cinco batidas (aqui a fonte sonora é propositadamente reconhecível: som de uma caixa-clara tocada com baqueta dura). O crescendo usa amostras curtas (entre aproximadamente 80 e 180ms), com uso ocasional de silêncios curtos (20 a 30ms) entre as amostras. Aqui, a articulação entre objeto sonoro e frase é aberta à ambiguidade.

A quinta parte da peça começa em 17.5s, com uma nota grave de piano soando, com uma camada de ruído, semelhante ao utilizado na parte 2, sobreposto. 0 decrescendo natural de intensidade da nota do piano é acompanhado pela camada de ruído, até que sobre apenas o ruído de intensidade baixa. Enquanto isso, uma outra camada de ruído, na qual é possível perceber frequências mais definidas, começa em primeiro plano. Essa camada tem sua velocidade de mudança ralentada, até ocorrer, em

101 Kreidler, J. Enviado por <jkreidler@gmx.de>.

102 Identifico o momento a partir de características morfológicas. Eles não foram especificados temporalmente pelo compositor. 
25.782s, uma transição. Uma pequena amostra é colocada em repetição. Em 26.644s começa a última parte da peça, que explora apenas uma amostra (um clichê musical, timbre filtrado para dificultar o reconhecimento da fonte sonora exata). Amostras de 33ms seguidas de pausas (de aproximadamente $100 \mathrm{~ms}$, gradativamente aumentando até $368 \mathrm{~ms}$ ) criam um ritmo e expectativa. O conteúdo harmônico de cada uso da amostra é o mesmo. Após um som de caixa-clara (esteira desligada), em 31.306s, a amostra se desvela, com duração de $2.25 \mathrm{~s}$.

A familiaridade que Kreidler procura estabelecer, ao inserir amostras de duração maiores, não apela para a identificação precisa das músicas utilizadas. O compositor, ao pensar sua Musik mit Musik, aborda a familiaridade através da evocação de clichês e gestos desgastados, uma familiaridade de estilos, um apelo ao pastiche. Em suas amostras mais reconhecíveis é possível indicar muito mais o estilo de música ou fonte sonora do que a música específica da qual a amostra foi extraída. Para reforçar essa estratégia, o compositor evita a utilização de músicas muito conhecidas, com as quais o público possa ter grande familiaridade e seja assim capaz de identificar particularidades e especificidades.

A maioria das amostras está tão transformada, ou dura tão pouco, que não é possível ouvi-las como algo que evoque referências. No entanto, ao alardear que utiliza um número enorme de amostras extraídas de músicas, Kreidler estabelece a ideia de que todas aquelas partículas sonoras, em um âmbito conceitual, se referem às músicas da qual foram extraídas. Product Placements de fato coloca músicas gravadas como tema e objeto da obra. No entanto, não são gravações que possam ser individualizadas. São músicas que, em uma era digital, circulam com grande velocidade pela internet, são comprimidas, carregadas e arquivadas; todas elas respondem à existência enquanto arquivo de áudio, compostas por simples variação numérica. A individualização das músicas, nesse contexto, remete à burocratização e às amarras burocráticas que limitariam a atuação de artistas que lidam com práticas envolvendo colagem musical.

Em Velocity as músicas amostradas foram escolhidas com o propósito de permitir um reconhecimento de suas identidades específicas ${ }^{103}$. Com a aceleração progressiva do sequenciamento de amostras, Oswald está justamente a jogar com a transição entre as escalas temporais Do Objeto Sonoro e Micro; quando a dificuldade de reconhecer as músicas utilizadas passa a operar como impossibilidade de reconhecimento, então há 
mudança na percepção correspondente com a mudança de escala temporal.

Em Product Placements, diferentemente, as músicas amostradas foram escolhidas com o propósito de permitir o reconhecimento vago do que se está utilizando, aqui e ali (no desenrolar do objeto sonoro final, principalmente). Há uma exploração de diferentes tipos de durações para as amostras, da escala Da Amostra até a Do Objeto Sonoro, também explorando a possibilidade de promover ou não a percepção da individualidade de cada amostra. Em O Chá, a reconhecibilidade é evitada a ponto de a pergunta sobre a identidade das músicas amostradas ser descabida, ou inexistente. Se foram ou não retiradas de músicas de Madonna e de Mozart, entre outros, isso não é importante; Importante é que as amostras servem de conteúdo, na escala Micro, para o processo composicional utilizado. As amostras são formatadas por este processo e resultam em uma massa estatística de amplitudes que geram um ruído agudo com certas características, com um movimento interno e uma agitação específica. Da mesma forma, em Product Placements, os milhares de fragmentos minúsculos transformam-se em ruído: uma sequência de amplitudes diversas ${ }^{104}$. Aproxima-se dos elementos mínimos, em que não há propriamente um som para se ouvir, mas apenas números de amplitude ou, no máximo, o entendimento de que há partículas sonoras sequenciadas - entendimento esse que se dá por uma decomposição da memória do som em elementos menores, não ouvidos, a princípio simbólicos, que caracterizariam o som ouvido. Mas seriam colagens musicais mesmo ou apenas um único ruído sintetizado? Kreidler, com a parte não-musical de sua obra, declara serem colagens; na parte musical, procura explorar extensivamente a gama de durações das amostras entre o mínimo possível e aproximadamente dois segundos. Essa exploração aponta para o uso efetivo de colagens musicais: o que era apenas um ruído desvela-se como várias amostras justapostas. No limite, seria como citar letras em um texto ${ }^{105}$. Analogamente, posso supor que Kreidler o faria, usando aspas, letras, espaços e por vezes sílabas: 'c"rec" "bo"o"m' 'V"i"o"L"ino'. E uma vez que se reduziu qualquer conteúdo a uma letra, pode-se desenvolvê-lo e assim chegar a outro conteúdo qualquer. Diminuir uma amostra musical a uma partícula sonora permite, com certo cuidado, que seja feita a operação contrária - a partir de uma partícula similar (mas impossível de diferenciar da anterior), aumentar sua duração até que seja reconhecível a

104 Há meios interessantes de conseguir resultados imprevisíveis, usando ordenações bastante rígidas. Basta que o controle exercido sobre a ordenação seja pouquíssimo correlacionado com aspectos musicais das obras. Exemplos são: ordenar por tamanho de arquivo ou por ordem alfabética do nome da obra, ou por ano de nascimento do compositor.

105 Nelson Goodman (1985), evita habilmente a possibilidade de que uma letra seja citada. De resto, sua abordagem sobre a citação musical é bastante distante da adotada no Capítulo 2. 
nova amostra; até que o processo seja percebido como a transformação de uma em outra.

Oswald, em Plexure (e, consequentemente, em Velocity), apoia-se na referencialidade, tal como específica à colagem musical: aquela que permite a identificação das músicas utilizadas e o aflorar dos sentimentos e lembranças próprias à familiaridade, vivida mais intensamente. Kreidler atenua esse movimento. Está interessado em problematizar a noção de apropriação e de citação, tanto legal como musicalmente: há de fato colagens musicais e citações? Onde? Há assim o intuito crítico de promover uma reflexão sobre direitos autorais, mecanismos de controle e práticas apropriativas. Para tal, a obra chama atenção para a tensão entre o que pode ser percebido e o que pode ser considerado como colagem musical.

Del Nunzio, por sua vez, passa ao largo dessa questão. Não há reconhecimento, mas principalmente, não há a questão do reconhecimento: não há extrarreferencialidade envolvida.

Ao trabalhar com músicas de outros como material musical, Kreidler desenvolveu um repertório de gestos musicais a fim de explorar relações de ambivalência quanto à identidade das amostras musicais utilizadas. Desta forma pôde colocar em prática a tentativa de explorar ambivalências quanto a dois tipos de escuta: escuta atonal, fenomenológica, orientada ao som; escuta semântica, orientada à memória. Os exemplos que ele fornece em sua palestra Music With Music são os que seguem.

Duração: a partir de um fragmento de música, repeti-lo espaçadamente, sempre de seu início, mas variando sua duração, de modo que ela seja progressivamente maior; a primeira ocorrência é uma partícula sonora sem identidade específica (um ruidinho), mas quanto mais as durações aumentam - quando o enjanelamento aumenta - mais emerge um objeto musical historicamente definido. Esse procedimento é utilizado em In Hyper Intervals (2006-8), parte 1, compassos 62 a $73^{106}$.

Dinâmicas ${ }^{107}$ : quando o som é menos intenso é mais difícil ouvir detalhes internos, e então é mais difícil definir sua identidade; havendo um crescendo, essa dificuldade desaparece.

106 A partitura está disponível em: <http://www.kreidler-net.de/english/works/inhyperintervals.htm>. Acesso em: 22 abr. 2012.

107 Acho mais apropriado utilizar as palavras intensidade ou volume para esse tipo de operação, por considerar dinâmica algo ligado à execução instrumental, que já estaria presente nos fonogramas utilizados. A operação seria, então, uma aplicação de um diferente volume sonoro modulando aquelas dinâmicas internas à amostra. 
Densidade Horizontal: vários fragmentos de músicas são tocados em sequência, justapostos; progressivamente esta mesma sequência tem seus fragmentos espaçados, e são inseridas pausas entre eles, cada vez maiores, diminuindo a densidade horizontal, tornando a sequência mais rarefeita. Assim, quando cada fragmento está suficientemente espaçado, há uma mudança da percepção para o reconhecimento da identidade de cada fragmento. Esse procedimento é utilizado em Dekonfabulation (2007-8), nono movimento, compassos 14 a $20^{108}$.

Densidade Vertical: fonogramas começam soando juntos (como um cluster), mas são progressivamente intercalados até soarem um por vez, em sequência justaposta. Nesse momento é muito mais fácil identificá-los.

Alternâncias: duas amostras musicais são dividas em várias partes; as amostras são então intercaladas, tocando-se a primeira parte de uma, depois a de outra, seguindo para a segunda parte de uma, depois a segunda da outra, sucessivamente. Para facilitar o reconhecimento da música deve-se tentar focar a escuta em apenas uma das amostras, fazendo um esforço para criar um ritmo de escuta: focar, desfocar, focar, desfocar. 0 procedimento é utilizado na parte 6 de In Hyper Intervals, compassos 39 a 59, só que alternando entre um fonograma musical e notas suaves tocadas ao piano.

Filtragem: em uma amostra musical, usar um filtro passa banda com um ajuste bastante estreito e abrir esse ajuste progressivamente até que haja filtragem pouca ou nenhuma; ou ainda: o movimento contrário. Vai da percepção da amostra como um átomo musical, ou um tom até que se torna possível perceber a emergência de uma música a ser reconhecida, identificada (ou vice-versa). A quinta parte de In Hyper Intervals utiliza esse procedimento algumas vezes.

Transposição: repetir o mesmo fonograma musical, mas cada vez transformado segundo uma transposição diferente, no campo das alturas. Aqui é colocada a pergunta: qual das transposições (das repetições) é o fonograma original, sem alterações? No início de Cache Surrealism (2008), esse procedimento é utilizado na parte eletrônica, criando uma melodia de transposições, que também estrutura aspectos melódicos do que os instrumentos não-eletrônicos tocam (violino, clarineta, percussão e piano). Também é utilizado no final de Living in a Box (2010), quinto movimento. (KREIDLER, 2010).

108 A partitura está disponível em: <http://www.kreidler-net.de/english/works/dekonfabulation.htm>. Acesso em: 22 abr. 2012. 


\subsection{Fontes}

Ouço um som e procuro reconhecer sua fonte. Reconhecer a fonte é também uma maneira de se comunicar compreensível e economicamente: em vez de descrever as características morfológicas do som, digo um nome. De qualquer forma, procuro por palavras, a fim de transmitir e localizar a experiência da escuta. Falo o nome da fonte, daquilo que supostamente causou o som. Esse nome, conforme mencionado no capítulo anterior, frequentemente é confundido e/ou utilizado como o nome do som, e não apenas da fonte. Tento evitá-lo, usando a preposição de: ouço um som de piano.

Não obstante, não se trata apenas de um som de piano, de um piano percebido através de seu som, ou melhor, de um som produzido por ele, ou de um som-piano (uma categoria confusa, mas válida - evidencia a confusão entre a causa e o efeito). Trata-se de um som de piano tocado por alguém específico; sei porque existem traços no som que me permitem reconhecer um modo de tocar. Como não sei descrever esse modo me permito nomeá-lo. Nomeando esse jeito, esse estilo específico de tocar piano, uso o nome daquele que o toca: Thelonious Monk.

Aqui ainda estou no no domínio do musical, do não-referencial, embora com a insegurança característica das zonas difusas e limítrofes. Thelonious Monk, o som, aquele som-Thelonious específico, na falta de uma descrição morfológica apropriada; o músico Thelonious Monk também como um meio: assim como o instrumento musical, o piano. Sua banda como a banda de Thelonious Monk - a maneira específica, os traços sonoros e composicionais.

Ao nomear o som dessa maneira, é quase dizer que aquele fragmento já contém em si um estilo inteiro, uma série de determinações complexas. Esse som como uma amostra sampleada e depois como holograma estilhaçado, na qual a parte contém o todo, e partindo para uma abordagem mais mística, endorsando as palavras de Genesis P. Orridge:

Sempre foi minha contenda pessoal que se pegarmos, por exemplo, um estilhaço [splinter] de JOHN LENNON, aquele mesmo estilhaço conterá em si, de uma maneira muito real, tudo o que John Lennon já vivenciou; tudo o que John Lennon já disse, compôs, escreveu, desenhou, expressou; todos que já conheceram John Lennon e a soma total de toda e qualquer uma dessas interações; todos que já ouviram, leram, pensaram em, viram, reagiram a John Lennon ou qualquer coisa remotamente conectada a John 
Lennon; o fuso horário específico, a data no calendário em que teoricamente residiu; e cada combinação passada, presente e/ou futura de qualquer ou todas as anteriores. (apud BAILEY, 2009, p. 97).

Mas não é isso. Músicos frequentemente se escondem atrás de seus instrumentos, em termos de postura corporal, quando se apresentam. Os instrumentos musicais, em si, escondem sua materialidade ao incorporar um discurso a respeito do musical - são meios, ferramentas para se chegar ao musical. Desviam a atenção, dizem não se tratar de percorrer o caminho, mas de chegar ao local. Assim também os músicos o fazem: o importante é a música e o musical.

Surge então um problema: de um lado o sentimento de que aquele som só poderia ter sido gravado por aquele músico específico; de outro, o poder agregador do nome como se tudo que tivesse a alcunha de Thelonious Monk não apenas gravitasse em torno desta. Como se houvesse uma real unidade entre esses objetos nomeados da mesma forma. Um som de piano remete ao seu funcionamento mecânico, a máquinas com martelos e cordas, a pedaços de plástico nas teclas que simulam marfim de elefantes? Esse questionamento é desviado: trata-se de um instrumento musical, e tal atribuição, pela circunscrição de uma funcionalidade, deve bastar para atenuar essas referências ao supostamente externo. Thelonious Monk também é músico, e sua função social deve atenuar a tendência a pensar seu modo de tocar em relação a sua pessoa, seus sentimentos e idiossincrasias.

Mas isso seria pouco. Passa essa escuta-identificação primeira, quase instantânea, como um mecanismo de sobrevivência: a linguagem se infiltra para não permitir a excessiva manifestação do indizível da escuta. Agora, décimos de segundo depois, escuto as notas. Sei que não são fonte: são unificadas pelo instrumento piano, de modo que não me pergunto se, tal como o instrumentário bateria é composto por tons, bumbo, caixa-clara e pratos, o piano é composto por vários instrumentos martelo-cordas, instrumento martelo-corda lá, instrumento martelo-corda si, um depois do outro. Escuto também um pequeno granulado: provavelmente de uma gravação em disco de vinil de uma obra do grupo de Monk. Não sei qual, mas identifico a possibilidade de um tocadiscos ser a fonte sonora. Seria então um toca-discos tocando uma gravação em disco de vinil de uma obra não identificada do grupo de Thelonious Monk, com Thelonious Monk ao piano.

Nesse momento paro de especular, e olho para meu computador: há um software 
(VCL) que toca um arquivo de som. O arquivo é indicado como Epistrophy, de Thelonious Monk, composta em 1942, provavelmente de um dos álbuns de nome Genius of Modern Music: Volume ${ }^{109}$. O VCL e o computador parecem transparentes - eu não ouço como poderiam ser parte da fonte sonora. No entanto, basta que eu feche a tela de meu computador e então ele entre em repouso, ou ainda que eu desligue o software para que a música pare. Olho para as caixas de som. Se eu desligá-las não haverá mais Thelonious Monk e banda, na agora identificada canção Epistrophy, gravada de um disco LP em um arquivo de áudio e reproduzida pelo aparato computador-VCL, que chega aos meus ouvidos. A fonte do som é então minha caixa de som. Normalmente, não há razão em chamar a atenção para o aparato reprodutor de som, que permanece estático, sem variação, fingindo-se de morto e portanto, não interferindo no mundo dos vivos. Isto é, transparente, ou ainda, invisível. Um espectro incorpóreo não derruba objetos na cozinha, mas sim o gato ou o vento; o vento forte, como uma caixa de som danificada, provoca efeitos perceptíveis - é a causa de eventos como a queda de utensílios de metal. Um vento fraco passa desapercebido - tanto quanto uma boa caixa de som, que reproduz o áudio.

Tem-se a postura ingênua com relação à identificação das fontes, quando da escuta de gravações, que desconsidera os aparatos de reprodução do som, apenas os levando em conta quando perturbam ou impedem a correta reprodução do fonograma. $A$ outra, postura obtusa: elenca os aparatos mediadores, leva a perguntas quanto aos microfones utilizados, entra em digressões. A avaliação de como proceder quanto a essas posturas, de como postar-se, dá-se caso a caso.

As fontes sonoras geram o som, após a ação humana, eficiente, que provoca essa geração de som. As fontes musicais são as informações que se relacionam àquele fazer musical específico daquela gravação/performance musical: a música que está sendo tocada, os músicos (seus nomes), possivelmente qual álbum, mas também qual estilo musical, qual compositor. Inferir a qual artefato cultural aquele som se refere ou de qual artefato cultural ele faz parte. Chamo essa operação de inferência de reconhecimento da fonte musical para diferenciá-la da operação de reconhecimento de fonte sonora, cuja preocupação é localizar a causa formal do som, os objetos e fenômenos que geraram o som.

Diferencia-se então nomear um som e reconhecer sua fonte. Quando reconhecer a

109 Há mais de um álbum com esse nome. A gravação que ouço falha em identificar corretamente qualquer nome de álbum do compositor. 
fonte é sobretudo uma maneira de nomear o som, não há propriamente uma intenção referencial; as propriedades do tipo de sonoridade correspondente ao nome são colocadas em questão, em detrimento da referencialidade. Quando, ao contrário, a ênfase cai sobre reconhecer a fonte, aspectos do objeto, fenômeno ou artefato são reforçados como referentes e, assim, a referencialidade é importante.

Estudos de plágio No. II: Thelonious Monk puzzle (2003), de Luiz Eduardo Castelões é uma obra eletroacústica. As amostras utilizadas advêm de obras do pianista de jazz Thelonious Monk. Segundo o próprio compositor,

na primeira seção, samples microscópicos são editados de forma a gerar ritmos obsessivos (aqui o reconhecimento da fonte é pouco óbvio e o trabalho composicional é intenso). Os samples vão ficando gradualmente mais longos, passando por trechos de alguns segundos (quando o reconhecimento se torna mais fácil e o trabalho composicional cada vez menos abrangente), até alcançarem quase a extensão de uma música inteira já na última seção. Neste final os samples não são sequer editados (o trabalho composicional é mínimo, ou quase ausente), ou seja, ouvem-se as músicas sampleadas inalteradas e sobrepostas, como se ouvíssemos um disco não da forma tradicional (uma faixa de cada vez), mas com todas as faixas soando simultaneamente. Para tocar no carnaval! (CASTELÕES, $\left.2003^{110}\right)$.

A peça traça uma relação inversamente proporcional entre quantidade e intensidade de trabalho composicional e reconhecibilidade das amostras. Quanto mais reconhecíveis as gravações de Monk, mais se aproxima do plágio como categoria e, portanto, menos trabalho composicional. Quanto menos reconhecíveis as gravações de Monk, mais serão necessárias as intervenções de Castelões, pois haverá mais espaço de atuação para ele como compositor. Interessante colocação quanto à possível saturação do espaço do autor: na obra, Castelões brinca de parafrasear estruturalmente o clichê dos filmes de faroeste, essa cidade não é grande o suficiente para nós dois.

Voltando à temática das fontes, quais seriam as fontes sonoras da obra? Se me concentrar no primeiro minuto: há um som de piano, mas mixado na gravação de maneira absolutamente não-realista; o som está com um panorâmico muito aberto, e isso chama suficientemente a atenção para não permitir uma resposta demasiado ingênua: as fontes sonoras são pianos. Ademais, um som começa e é interrompido de maneira artificial - é uma colagem e, conforme o título, trata-se de gravações do pianista Thelonious Monk. Gravações antigas, com resíduos sonoros do antigo - um tipo de sujeira sonora 
específica, granulada, um tipo de opacidade espectral. E silêncios: cada fragmento intercalado com silêncio digital - não há som de sala, o silêncio como interrupção do fluxo de dados, como corte do som -, um silêncio sem espaço, mudo. E repetições idênticas dos fragmentos, com consequente aumento de seu tamanho. Aqui já há a sensação de que a fonte sonora é um sampler digital, operando com fonogramas em que Thelonious Monk toca piano, sozinho.

O piano é um instrumento musical. O sampler também, mas não do mesmo tipo. Ambos os instrumentos têm maneiras de operar características, mas diferentemente do piano, que é relativamente homogêneo sonoramente, o sampler [amostrador] não tem um som próprio a priori - ele precisa de conteúdo sonoro externo ou estar exposto a condições extremas de amplificação e retroalimentação. Como instrumento musical sem conteúdo sonoro próprio, o amostrador possui potências, não apenas de musicalizar os sons nele armazenados. Com o uso repetido de certos sons em amostradores e softwares com funções de amostradores, há uma tendência de desreferencialização destes sons, cada vez mais convertidos em conteúdo sonoro do instrumento musical. Essa tendência seria similar à existente nas operações de loop: colocar algo em repetição torna mais provável que o som em si (em suas qualidades internas) seja escutado. Fato análogo é exemplificado em algumas obras da escritora Gertrude Stein, em que a repetição obsessiva de certas palavras retira-as do plano semântico e extirpa-lhes seus significados.

Se o piano, instrumento musical bastante difundido, estava a se tornar transparente demais - muitas obras de artistas do movimento Fluxus, principalmente na década de 1960, procuraram desconstruir essa transparência, revalorizando a fisicalidade do piano, seu aspecto de mobília, seus mecanismos ${ }^{111}$. Com o amostrador o movimento é contrário: tornar certos conteúdos sonoros menos referenciais, pela recorrência e repetição; aproximá-los da ideia de que sejam um conteúdo próprio ao sampler. Passível de identificação como a fonte sonora, o amostrador promoveria um vetor de deslocamento quanto às fontes musicais: não mais as músicas de Thelonious Monk tocadas por ele ao piano, mas a obra de Luiz Eduardo Castelões. Quando recorre menos a ações instrumentais de amostramento, ações do instrumento musical amostrador, o aspecto referencial da obra vai sendo reforçado, e as gravações de Thelonious Monk e banda, como fontes musicais, tornam-se importantes. Esse processo coloca em prática (em 
música) um questionamento acerca da relação entre trabalho composicional e autoria. E suscita uma reflexão: com a diminuição do trabalho composicional ocorreria também uma diminuição de autoria? Ser autor como um fazer.

\subsection{Timbre}

Antes da fonografia o timbre só podia ser indicado, mas não notado em si, nem inscrito. Sua notação se dava por uma indicação de ação: com tal instrumento, tocar tais notas, executar tais ações. Isso gerou uma tendência para a identificação do timbre de algo, ora com sua fonte sonora, ora com sua fonte musical.

É possível que chegue um momento em que qualquer timbre, ou qualquer comportamento timbrístico, possa ser replicado e imitado. Estaremos mais próximos da ficção cyperpunk de William Gibson, de um homem tomado por sua tecnologia, de um homem inumano (mas também de uma tecnologia humanizada). Algo mais hiperrealista que o experimento de Sven König, quando faz seu avatar, um Michael Jackson luminoso e sonoro de baixa resolução, repetir suas palavras ${ }^{112}$ : o software procura os trechos de falas em uma entrevista dada por Jackson para uma emissora de TV cujos conteúdos espectrais sejam os mais próximos aos da fala de König, fragmento por fragmento. Um momento em que os timbres existentes passem a ser um material muito maleável, em que se possa traçar planos de variação, em degraus, mas também em intervalos contínuos, entre pontos antes separados por abismos - processos de desindividualização desses pontos. Onde Stockhausen definiu sete níveis de inteligibilidade para o material vocal utilizado em Gesang der Jünglinge (1956), poder-se-ia, nesse futuro hipotético, ir em $n$ passos ou $m$ segundos, dos gemidos de Britney Spears até o bel canto de Maria Callas. Mas não se trataria de metamorfosear um som em outro - como Trevor Wishart em Vox $V$ (1986), por exemplo, ou como ocorre entre os vários fragmentos de música em Plexure, de John Oswald. Tais metamorfoses manteriam aqueles sons como pontos fixos, retirados das obras a qual advieram. Contrariamente, seria a ocasião em que o nome Maria Callas indicaria somente uma nomeação popular, historicamente motivada, de uma série de características determináveis e controláveis. As obras de Maria Callas - suas gravações passariam apenas a ser um caso específico e restrito das articulações possíveis dentro

$112 \mathrm{Na}$ apresentação do projeto sCrAmBIEd?HaCkZ! (KÖNIG, 2006). 
daquele complexo e fortuito amontoado de parâmetros.

Entretanto, conquanto os nomes apareçam e firmem-se fortes, nesse caso, em que o nome é uma resistência contra a homogeneização do campo timbrístico - nomes como Oops! I Did It Again (Spears) - ou ainda adjetivos que remetam aos nomes - divina, inesquecível (Callas) -, então, mesmo assim, está-se a confiar na referencialidade. É na confusão entre timbre e comportamento sonoro, entre a libertação do timbre como material e sua colonização por marcas sonoras que se estabelece essa tensão entre autonomia e heteronomia na música, neste pequeno experimento de pensamento (nesses parágrafos acima).

Em Let Them Sing For You (2003), Erik Bünger transforma um texto colocado pelo usuário em uma colagem musical: sílabas e palavras de diversas canções estão armazendas em um banco de dados. Sobre a escolha destas, Bünger escreve:

Minha concepção para a lista de palavras era um pouco como 'nós somos o mundo' [We are the world]: quando cada cantor famoso tem só dois segundos, ele/ela faz tudo o que pode para comprimir todo seu estilo pessoal naqueles segundos. Bruce Springsteen nunca soou tão rouco, Cindy Lauper nunca soou tão infantil. Tentei coletar palavras que expressassem a persona específica de cada cantor, de modo a haver uma colisão, não apenas de sons, mas também de tudo o que cada voz representa. Eu também tentei variar os estilos o máximo que pude a fim de criar um sentimento verdadeiramente caótico que brinca com a memória de cada ouvinte: como cheirar um monte de odores familiares ao mesmo tempo. (informação pessoal ${ }^{113}$ ).

Se uma frase como "I like to move" [eu gosto de me mover] fosse escrita, ter-se-ia uma sequência de fragmentos de Wicked Game (1989), de Chris Isaak, Master and Servant (1984), do grupo Depeche Mode, How Sweet It Is (To be Loved By You) (1964), de Marvin Gaye e Harlem Shuffle (1963), de Bob \& Earl.

Deixe que eles cantem por nós; canções dispersas, de memórias e fragmentos: memória contra a semântica. Os timbres acabam arquitetando uma relação em que a referencialidade age contra a inteligibilidade e a compreensão do texto. Depois de algumas incursões, ao colocar ainda outro texto, a fim de gerar ainda outra canção, já há antecipações. A cada letra, sílaba ou palavra digitada delineiam-se certas imagens sonoras. Há então uma possível aceleração artificial de um processo de colonização da escritura, em que "ocorre o retorno das vozes pelas quais o corpo social 'fala' em citações, em fragmentos de frases, em tonalidades de 'palavras', em ruídos de coisas." 
(DE CERTEAU, 1980, p. 257).

Michel de Certeau fala sobre a leitura, de como ela carrega seus fantasmas, que a povoam por citações e erupções sonoras, mantendo uma tradição do corpo dentro das atividades de leitura e escrita. Quando os fantasmas são trechos de canções pop de sucesso artificialmente implantadas nas palavras, há uma ameaça dessa tradição do corpo ser mascarada pela tradição da produção de homens-imagem e mulheres-imagem, em erupções que falham em referir a uma materialidade, por excesso de mediação. Em $A$ Invenção do Cotidiano, continua De Certeau:

São com efeito reminiscências de corpos plantados na linguagem ordinária e balizando-a, como pedrinhas brancas na floresta dos signos. Experiência morosa, finalmente. Marcados na prosa dos dias, sem comentário nem tradução possível, continuam sendo os sons poéticos de fragmentos citados. 'Existem' em toda a parte essas ressonâncias de corpo tocado, como 'gemidos' e ruídos de amor, gritos que vão quebrando o texto que farão proliferar em torno de si, lapsos enunciativos em uma organização sintagmática de enunciados. São os análogos linguísticos da ereção, ou de dores sem nome, ou das lágrimas: vozes sem língua, enunciações que fluem do corpo que se lembra, opaco, quando não dispõe mais do espaço oferecido pela voz do outro ao dizer amoroso ou endividado. Gritos e lágrimas: afásica enunciação daquilo que sobrevém sem que se saiba de onde (de que obscura dívida ou escritura do corpo), sem que se saiba como, se a voz do outro, se poderia dizer isso.

Esses lapsos de vozes sem contexto, citações 'obscenas' de corpos, ruídos à espera de uma linguagem, parecem certificar, por uma 'desordem' secretamente referida a uma ordem desconhecida, que existe o outro. Mas ao mesmo tempo vão contando interminavelmente (é um murmúrio que jamais para) a expectativa de uma impossível presença que muda em seu próprio corpo os vestígios que deixou. Essas citações de vozes são marcadas numa prosa cotidiana que não pode, em enunciados e em comportamentos, senão produzir seus efeitos. (idem, 258).

Não que Bünger tencione ou vá colonizar essa prosa cotidiana, substituindo-a por práticas de passividade frente a produtos de consumo em massa. Não que ele proponha qualquer substituição, na prática da escrita e da leitura, dos resquícios de vozes pelas elocuções máximas de certos ícones do cancioneiro pop.

\subsection{Familiaridade}

No capítulo 1, tópico 1.1, descrevi rapidamente parte das intenções por trás da estética apropriativa de Michael Finnissy. Retomo três dos pontos mencionados, 
reescrevendo o terceiro de modo a melhor abordar a questão da familiaridade. São eles: reagir aos diversos estímulos musicais existentes; tornar a produção musical mais acessível; enfatizar os processos composicionais envolvidos.

A incorporação de material musical alheio aponta para uma reação à escuta desse material, como se a escuta não bastasse e fosse preciso algo mais - incorporações, intervenções, explicitações. Thomas Edison, ao criar o fonógrafo, no final do século XIX, já tinha atribuído a este o papel de preservar a voz dos mortos (mais precisamente o som da voz dos mortos) $)^{114}$. Analogamente é possível pensar os processos fonográficos como preservadores de músicas mortas, músicas que já aconteceram, ou que nunca aconteceram $^{115}$. A expressão popular ao vivo reforça essa possibilidade: uma música que não se põe ao vivo põe-se sem vida? Passa a perseguir os vivos, a fim de tomar o espaço imaginativo destes? Tal pergunta é próxima à ideia estabelecida na abertura do artigo Plunderphonia, de Chris Cutler, publicado inicialmente em 1994:

Até 1877 , quando a primeira gravação sonora foi feita, o som era algo predicado em seu próprio desaparecimento imediato: hoje em dia é cada vez mais um objeto que vai durar mais que seus feitores e consumidores. Recusa-se a desaparecer, causando um grande peso de música morta a pressionar os vivos. O que fazer com isso? Uma resposta orgânica tem sido a reciclagem. (CUTLER, 2004, p. 138).

As músicas preencheriam um espaço de escuta, pressionando "os vivos" (os ouvintes), ocupando todo o espaço destes. A perseguição passa a se insinuar em um âmbito mais íntimo, dada a escassez de espaço. Forjam-se imagens diversas dessas batalhas da escuta: de um vírus tentando se alojar; da melodia como algo inumano, lutando por preservar-se na memória e nos dispositivos de memória humana (à maneira de Bünger (2010) no vídeo The Third Man); de mortos-vivos à procura de comida (as gravações carregam músicas que, não possuindo memória própria, precisam da memória dos humanos. Os mortos-vivos, ao morder os humanos em busca de alimento, transmitem o vírus responsável pelo fenômeno e infectam os cérebros alheios, que então degeneram; os humanos deixam de ser humanos e tornam-se replicantes, tornam-se mortos-vivos. Como se aquela música que infectou a memória fosse exigir um tributo: que seja replicada, que seja tocada mais vezes, de modo a possivelmente infectar também

114 Vide tópico 1.4.

115 Seria o caso daquelas feitas em estúdio. Obviamente essa analogia é simplista, mas deve bastar por aqui. 
outros $\left.{ }^{116}\right)$.

Seguindo esse padrão comparativo, encontro a imagem do pesadelo, evocada por Karl Marx, em um texto de Fredric Jameson (1997, p. 4, tradução nossa):

Picasso e Joyce não deixaram apenas de ser feios; eles agora nos são, no geral, bastante 'realistas', e isso é o resultado de uma canonização e institucionalização acadêmica do movimento modernista que geralmente pode ser traçada no fim da década de 1950. Isso é certamente uma das mais plausíveis explicações para a emergência do Pós-Modernismo em si, uma vez que a geração mais jovem da década de 1960 irá confrontar agora o outrora opositivo movimento moderno como um lote de clássicos mortos, que 'pesam como um pesadelo nos cérebros dos vivos', como Marx disse uma vez num diferente contexto.

Em um espaço moderno, a tradição pode ser um fardo pesado demais. Assim, é prevista a possibilidade de um novo começo, seja ele uma reavaliação ou um abandono, isto é, da formação de um espaço pós-moderno. Em um espaço saturado musicalmente, o fardo que se delineia é o da homogeneização da escuta, quando esta, ao se familiarizar demasiadamente com certas músicas, e atordoada de tanto ouvir músicas, pode se transformar em uma atividade passiva, uma atividade atenuada. Assim, colocar mais músicas nesse espaço, lançar mais álbuns de música seria, de certo modo, contribuir para sua crescente saturação. Tentar colocar músicas demasiado não-familiares seria arriscar não penetrar neste espaço, isto é, cair fora dele.

Portanto, utilizar como material músicas que saturam o espaço - reciclá-las, mostra-se uma alternativa interessante. Estabelece uma relação de reação ao espaço saturado que não é de repulsa, mas de apropriação, ou ainda, de reapropriação do espaço de escuta. Ao evidenciar a origem do material, essas colagens musicais mantêm um elo explícito com o espaço no qual se inserem; essa ação permite a efetiva colocação no espaço de saturação ${ }^{117}$. A familiaridade do material então torna essas produções mais acessíveis, pois podem ser escutadas a partir desse espaço. A familiaridade com o material seria como um "fator ao qual se agarrar" [something to hold on to factor] (LANDY,

116 Há uma série de filmes com esse tema, explicitando ou não a existência de um vírus ou T-virus. Um exemplo contemporâneo é Resident Evil (ANDERSEN, 2002). Abordando esse filme, poder-se-ia também fazer uma analogia entre a Umbrella Corporation e as megacorporações equivalentes no campo da música pop.

117 Aqui vale um porém: não estou dizendo que as colagens musicais aqui abordadas participem do espaço de saturação da escuta da mesma forma que a música pop. Isto é, a música pop continua com uma presença urbana quase ubíqua que faz com que elas sejam escutadas, quase que invariavelmente. As músicas que as reciclam, dentro de um contexto experimental, evocam esse espaço, uma vez que escutadas. 
2007, p. 26). Segundo Leigh Landy, os compositores podem tornar suas obras musicais mais acessíveis "oferecendo aos ouvintes algumas dicas, declaradas ou, simplesmente, implicadas, a respeito de como estes poderão achar seus caminhos [de escuta] durante as peças" (idem).

Um dos caminhos oferecidos aos ouvintes seria o do reconhecimento do material e consequente reconhecimento de seu deslocamento. Esse recontextualização teria como estratégia provocar uma ruptura: acostumado em demasia com o conhecido, o ouvinte o escuta de modo pouco ativo; com o deslocamento do conhecido há também um deslocamento de escuta, do que havia de já automatizado nela. Então surge uma dupla atribuição ao ouvinte: ter de escutar mais ativamente, por ser algo não conhecido; e traçar um paralelo com o conhecido - um foco no deslocamento operado, o que corresponderia a uma ênfase nos processos de composição: transformações e combinações.

Escutar músicas é uma parte integrante e importante da vida da maioria das pessoas. Essa escuta se dá, com o advento da fonografia, e especialmente em centros urbanos, por meio de gravações de música. A saturação aqui aludida, se efetiva, por um lado faz com que a presença constante de várias músicas no ambiente sonoro cotidiano atenue o hábito de escutar concentradamente; por outro, que a ênfase dada a certas músicas, que são tocadas repetidamente neste mesmo ambiente, resulte em um apego emocional a estas e uma circunscrição do espaço de escuta em torno destas. Gjerdingen \& Perrot (2008, p. 94-5) falam inclusive de um "período de plasticidade", constituído da puberdade até o início da fase adulta, onde o mapa de gêneros musicais de um indivíduo se forma. Esse mapa, cuja tendência é ser mantido por anos e anos pelo indivíduo, conterá artistas e gêneros prediletos. A fim de garantir resultados economicamente satisfatórios, gravadoras comerciais focam então seus produtos - suas músicas - em um público de idade jovem. Partirão do pressuposto que, uma vez colocados no espaço de saturação da cultura pop durante sua adolescência, os ouvintes-consumidores apegar-seão não apenas aos artistas e músicos específicos, consumindo seus produtos, mas acostumar-se-ão a esse espaço, a esse tipo de articulação de escuta. Escreve Jameson (1979, p. 137-8, tradução nossa) sobre esse tipo de saturação, em 1979:

Arguirei que nós nunca ouvimos nenhum desses singles produzidos nesses gêneros [música pop contemporânea ou qualquer tipo - os vários tipos de rock, blues, country ou disco] 'pela primeira vez'; em vez disso, 
nós vivemos sob uma constante exposição a eles em todos os tipos de diferentes situações, da constante batida do rádio do carro até os sons no almoço, ou no local de trabalho, ou em shoppings, até aquelas performances aparentemente integrais [full-dress performances] da 'obra' em um clube noturno ou show em estádio ou dos discos que você compra e leva para casa para escutar. Isso é uma situação muito diferente da primeira audição desnorteada de uma peça clássica complexa, que você ouve de novo na sala de concerto ou escuta em casa. A conexão passional que alguém pode formar com esse ou aquele single pop, o rico investimento pessoal de todos os tipos de associações privadas e simbolismos existenciais que caracterizam esse apego, são tanto função de nossa própria familiaridade com a obra quanto função da obra em si: o single pop, por meio da repetição, insensivelmente se torna parte do tecido existencial de nossas vidas, de modo que escutamos a nós mesmos, escutamos nossas próprias audições prévias.

O apego a certas músicas, entretanto, não precisa ser colocado como algo ruim, como um aspecto puramente regressivo da escuta. Antes de moralizar a questão é preciso colocá-la como característica. A formação da identidade pessoal de muitas pessoas muitas vezes passa por uma identificação com certos estilos musicais e pela escuta repetida de certas músicas. Sempre é possível idealizar um mundo em que isso não aconteça, e contrapô-lo a um mundo reificado, em que tudo é instrumentalizado pelas relações de consumo. Mas isso seria justamente um modo de evitar a questão a fundo, a questão de como lidar com uma parte importante da experiência de ouvinte, a que diz respeito a seus afetos enraizados, a seus apegos patéticos; ao que está familiarizado demais. Lidar com essa questão passa pela atenção a um estado em que o ouvinte transforma-se em um fã que não mais ouve, um estado que pode proporcionar prazer, mas que não é interessante em termos musicais. Sobre esse perigo escreve Adorno (2011, p. 95):

O ouvinte que retém um hit e volta a reconhecê-lo transforma-se, em um âmbito imaginário e prenhe de elementos psicológicos, no sujeito que responde idealmente ao hit. Como um dentre os muitos que se identificam com aquele sujeito fictício, o Eu musical, ele sente seu isolamento atenuarse imediatamente, integrando-se à comunidade de fãs.

Prosseguindo, fornece o pior cenário possível, em sua concepção:

Mas o fã, cuja necessidade daquilo que lhe é imposto pode elevar-se à euforia embotada e às tristes sobras da antiga embriaguez, é educado mediante o sistema global da música ligeira com uma passividade que, possivelmente, também é transposta a seu pensamento e a seus comportamentos sociais. (idem). 
Trevor Wishart, por exemplo, atribui o que ele chama de função totêmica a esses estilos que acabam por promover um sentido de integração social, contornando a sobremoralização desse sentimento de comunidade e pertencimento que resulta da escuta de uma música ou tipo musical:

Mesmo com seres humanos, certos estilos musicais (por exemplo, os estilos do rock associados com tipos particulares de vestimenta, cortes de cabelo e até mesmo modos de falar; até mesmo o repertório clássico ocidental em meio à sociedade branca de classe média na África do Sul) podem cumprir uma função totêmica básica, indicando uma filiação em um grupo social particular e exclusivo e vinculando um aos outros da mesma 'espécie'. No nível das nações, certas 'canções-fórmula' [song-formulae] conhecidas como hinos nacionais também podem servir como símbolos sonoros totêmicos. (WISHART, 1996, p. 252-3).

Em Hymnen (1966-7), de Karlheinz Stockhausen, Wishart sugere ser um importante aspecto da percepção da obra notar o "distanciamento desse totemismo nacional, e realização de comentários sobre ele, usando técnicas eletrônicas de transformação das 'fórmulas-canção' [song-formulae]." (ibidem) Tanto em Hymnen quanto em Telemusik (1966), também de Stockhausen, que por sua vez usa fonogramas de músicas folclóricas diversas, essas amostras são usadas e absorvidas dentro de uma estrutura maior estipulada pelo compositor, e combinadas e moduladas por sons eletrônicos, como se, ainda de acordo com Wishart, intentassem

sugerir uma forma particular de relação com a música preexistente, ou seja, sua absorção em um processo maior e assim uma visão de fora ou acima do substrato cultural de onde as músicas vêm. Estamos aqui em uma espécie de mídia 'cósmica' espacial que, genericamente, não tem referência do mundo real. Esse 'distanciamento' ou desapego do real (sem espaço acústico reconhecível, sem referentes reconhecíveis do mundo real, apesar de alguns tipos de processos naturais serem sugeridos em Hymnen) nos predispõe a perceber as músicas pré-gravadas (elas mesmas comumente distorcidas pesadamente) de uma maneira distante. Porém, como são os únicos elementos que referem diretamente à nossa experiência de espaços acústicos reais, é como se estivéssemos vendo o mundo real à distância. (ibidem, p. 145).

Essa visão cósmica se liga ao discurso mais místico de Stockhausen, quanto à existência ${ }^{118}$, mas também à sua vontade de criar uma música que estivesse acima das tradições locais, de produzir uma metáfora musical para um tipo de união entre essas tradições, povos, nações. Enfim, posiciona-se de forma a não aceitar passivamente a 118 Vide, por exemplo, Marconi (1981). 
identificação com as nações, via hinos, e a identificação com os povos e tradições, via músicas folclóricas. Nas áreas criativas a passividade é quase sempre mal vista, por ser por princípio conservadora. Mostro em seguida algumas estratégias para lidar com a familiaridade, sem recair nesse puro estado de identificação e afeto intenso, em que se ouve mas quase não se escuta, isto é, em que a escuta está atenuada, adormecida.

No meu caso pessoal, a que pese um exemplo, odiava as canções de dance music, da década de 1990, como What is Love (1993), do grupo Haddaway, ou a versão de Double You para Please Don't Go, lançada primeiramente pelo grupo KC and the Sunshine Band, em 1979. Tinha cerca de dez anos e sentia-me forçado a escutá-las durante festas dos meus colegas de escola, em Campinas. O contato com elas, isto é, a escuta delas, gerava um sentimento de rejeição e de não-pertencimento; de afastamento social. Quando pude distanciar-me um pouco delas, mais de quinze anos depois, vi-me na oportunidade de lidar com meus antigos afetos e dar a essas músicas uma segunda chance. Estranhamente, hoje em dia, tenho sensações boas quando as escuto com um foco emocional - como se hoje pudesse me integrar mais aos meus colegas do que podia na época, na infância. A fim de rematar essa pendência emocional, fiz um arranjo para piano (remediando as Gymnopédies (1888), de Erik Satie), de Please Don't Go, e incluí amostras de ambas, tanto em Primeiro Acorde (2008) quanto na versão inicial de Autorretrato: Fim da História/Esquizofrenia (no prelo) ${ }^{119}$.

Na primeira seção de Primeiro Acorde, para eletrônica e sintetizador, diversas amostras curtas contendo o início de canções de sucesso comercial são tocadas em sequência: o tecladista intervem com ruídos improvisatórios entre as amostras, nos poucos décimos de segundo que porventura as separam (tipicamente entre 0.2 e 0.8), procurando traçar arcos gestuais e energéticos entre os fragmentos. ${ }^{120}$

Enquanto isso há um jogo de reconhecimento. Para o ouvinte, de qual canção se trata, de qual artista, de que época (de que ano, aproximadamente, mas certamente de que década ${ }^{121}$ ); para o compositor, quantos décimos de segundo são necessários para que o ouvinte saiba essas informações, se a música for familiar a ele. Oswald alertara:

119 Tocada com o nome Da Série "Transposição Musical, por Analogia, dos Estudos Críticos Marxistas": Fim da História/Esquizofrenia duas vezes, na série de concertos NME, [NME3], em 04 e 09 de novembro de 2011, na Sala 108, Unesp (São Paulo) e Sala Paes Nunes, Unicamp (Campinas), respectivamente.

120 Concentro-me na primeira seção da peça, que segue dessa maneira por alguns minutos (com um limite máximo de amostras mostradas, na versão de 2008, de 352).

121 É comum atribuir uma música, gênero ou estilo musical a uma década específica, no que concerne ao repertório da música pop. Entretanto, essa convenção é, como se pode esperar, cheia de imprecisões e exceções, afora o fato de ciclos mais complexos serem agrupados grosseiramente em períodos de dez anos. 
"Fontes de música popular entram dentro de nós [Popular music sources get inside one], mesmo que você não goste delas. Elas são involuntariamente aceitas." (apud STEENHUISEN, 2009, p. 130). Todas aquelas canções famosas, especialmente as que ouvi durante a puberdade e a adolescência, entre 1994 e 1999, mesmo que involuntariamente (só comecei a considerar músicas do pop ou rock escutáveis a partir de 1996), reconheço-as muito rapidamente. Como reflexo aos sons de música pop, quero identificá-las. Com 0.3 segundos é possível, em boa parte dos casos, dizer da fonte musical da amostra. É claro, esse reconhecimento depende se o começo da música representa bem, sonoramente (ou timbristicamente), a música como um todo. Ademais, pode-se editar as amostras a fim de trabalhá-las mais, de modo a valorizar suas características musicais próprias, seus ritmos e fraseados.

No artigo Scanning the Dial: The Rapid Recognition of Music Genres, Gjerdingen \& Perrott (2008) abordam os resultados de um experimento em que os participantes, ao ouvir trechos curtos de músicas comerciais, deveriam assinalar a qual dos dez gêneros disponíveis elas pertenciam. Segundo eles,

a velocidade com que os participantes eram capazes de realizar tal tarefa" foi algo inesperado. E continuam: "O que é chamado, pela falta de um termo melhor, de 'timbre', encerra todo a variabilidade espectral e rápida de domínio temporal no sinal acústico. Tal informação pode ser altamente indicativa de gêneros particulares. (GJERDINGEN \& PERROTT, 2008, p. 98).

Logo concluindo:

Se identificação de gênero, como categorização contextualizadora, requirisse classificações prévias de componentes como melodia, baixo, harmonia e ritmo, seria improvável que tão rápida identificação seria possível. (...) Em um modo reminiscente de efeitos Gestalt, pareceria que ouvintes podem atingir uma categorização global de gênero no mínimo tão rapidamente quanto podem categorizar qualquer componente. Presumivelmente categorização de gênero é uma resposta aprendida, e a rapidez desta resposta pode refletir a grande significância social e pessoal de gênero de música no mundo moderno. (ibidem, p. 100).

E se há reconhecimento muito rápido do gênero também há dos principais representantes, no que concerne a memória, de cada gênero musical. Mais que isso: há uma espécie de rememoração instantânea, atuando como um reflexo, mostrando um hábito enraizado de identificação. Que boa parte dos ouvintes possa responder desse 
modo, reflexivamente ${ }^{122}$, é algo explorado na peça Primeiro Acorde. A exposição a diversas amostras de canções famosas pode provocar o sentimento de reconhecimento destas, mas o tempo para formular o reconhecimento, para significar a experiência como uma identificação, é por vezes maior do que o tempo entre uma e outra amostra tocada. Há então uma sobrecarga do reconhecimento, o que deve levar, em tese, cada ouvinte a estabelecer uma estratégia de escuta própria à sua capacidade de reconhecimento e significação deste reconhecimento. Ou seja, há a vontade de colocar os ouvintes em um estado de incompletude de memória e afetos suscitados. Basta o primeiro som do primeiro acorde de Smells Like Teen Spirit (1991) para que se reconheça a música, a despeito do motivo-gesto incompleto, que conteria mais duas reiterações desse acorde. Muito mais tempo é necessário para que termos como Nirvana e década de 1990 venham finalmente à tona, e mais ainda para lembranças relacionadas a uma suposta época de rebeldia leve, clubes frequentados por menores de idade e, por exemplo, garotos pulando para dentro de carros pelas janelas abertas, rodas de dança agressiva e combativa.

Não obstante, esse jogo de reconhecimento não é o único aspecto da peça, porque arriscar-se-ia a tê-la como um experimento social ${ }^{123}$. Ele é intercalado ou colocado em paralelo com duas outras sugestões: da escuta dos gestos, das transições entre fragmentos, das trajetórias sonoras; da escuta do aparecimento de ruídos e texturas sonoras interessantes entre as amostras (como na varredura de sintonia, quando da operação de um rádio analógico, passando de uma estação a outra, passando por regiões onde não há nenhuma estação, procurando um conteúdo musical interessante). Acordar a escuta, no sentido de tirá-la de um estado de conforto. A busca por um entrelaçamento entre memória e gesto, som e significado.

Uma formulação que articula a noção de familiaridade, de modo a constituir com ela um artifício expressivo, é realizada por Oswald ao elaborar o conceito de gancho. Em entrevista com Norm Igma ${ }^{124}$, Oswald (2000, p. 9) define o termo plunderphonics como "a transformação radical de música muito familiar". Continua:

Qualquer ponto, em uma música, no qual você sinta que chegou a um local de relaxamento ou de bem estar ou de familiaridade ou tudo isso. Um lugar

122 "Reflexivamente", de reflexo, o que, curiosamente, tem um sentido completamente distinto, e até mesmo parcialmente contrário da frase "promovendo a reflexão sobre".

123 Não que um experimento social não possa ser música. Entretanto, não é o caso.

124 Suspeito se este não seria um personagem concebido por Oswald. Aparece como pertencente à equipe do Mystery Lab, nos créditos do disco Greyfolded (1995). 
como o lar. (...) Toda canção de sucesso (...) tem elementos virais, ou ganchos, que vão para dentro de você e lá se alojam, se tornam parte de você. (ibidem, p. 13).

Assim, o gancho seria esse ponto, em uma música que provoca um sentimento de grande familiaridade. Usar fragmentos que possam acionar esses ganchos no ouvinte é um procedimento utilizado em colagens musicais, especialmente no plunderphonics, em que há a tentativa deliberada de trabalhar a partir de ganchos ${ }^{125}$. Ainda outra definição de plunderphonics, resguardada até então, revela de modo claro essas intenções, apesar de nesta Oswald empregar imprecisamente a expressão memórias melódicas, quando poderia ter falado em memórias sonoras: "'Plunderphonics' é um termo que cunhei para cobrir o mundo contra-secreto [counter-covert world] dos sons convertidos e músicas reformadas onde memórias melódicas coletivas do familiar são picadas e reabilitadas para uma nova vida." (STEENHUISEN, 2009, p. 128).

Em Plexure há também excesso na quantidade de músicas usadas como material. A obra trabalha com inúmeros ganchos e explora a possibilidade de compor com eles situações sonoras que estejam no limiar do reconhecimento de suas fontes musicais. Oswald está interessado na possibilidade de mostrar como, apesar de rapidamente reconhecíveis e capazes de individualização sonora, esses hits diversos são altamente similares em alguns casos. Interessado em aspectos ilusórios, utiliza fusões sonoras: processos de metamorfose espectral, de um som a outro, tornando mais difusas características espectrais de várias amostras e facilitando sucessões suaves de uma a outra. Monta a maioria dos trechos com encadeamentos que mantêm um fluxo musical contínuo, diluindo assim as individualidades das amostras em uma textura mais propriamente oswaldiana, em uma colagem que, em grande parte do tempo, procede acelerando rumo a andamentos cada vez mais rápidos, como dito anteriormente. Há ainda inúmeros trechos facilmente reconhecíveis. Em outros, há uma sensação de grande familiaridade, mas a resposta quanto à fonte musical vacila. A familiaridade da música pop, que resulta em ganchos, é pautada por uma uniformidade estrutural grande, ao mesmo tempo que uma individualização máxima dentro desse esquema. Oswald tenta realizar uma desconstrução: mostrar até que ponto é possível pensar um hit como seu próprio pastiche.

125 A ponto de Katharine Norman mencionar "Toda faixa do CD Plunderphonic de Oswald confia na informação que você possui [relies on your input] - nomeie o tema e ria de sua nova encarnação." (NORMAN, 2004, p. 190). 
Oswald se interessa pelo deslocamento do particular. Esse particular é uma música, e para que seja compartilhada como particular é mais efetivo que seja bastante conhecida - um sucesso comercial, de preferência. Em Plexure, através dessa identificação de particulares, Oswald quer traçar semelhanças, características comuns, com relação à estrutura da música e seu conteúdo: como, apesar de muito particular, aquela música é similar a inúmeras outras. Quer mostrar como há uma fabricação, um artifício, entre o hit e o gênero, o particular e o genérico. Quer mostrar como a base genérica-estrutural permite a eleição, a criação de um representante máximo, com diferenciações sutis de conteúdo. Como essa base permite o desenvolvimento de timbresmarcas, de gestos característicos, de estilemas sonoros, dentro de uma gama estilística reduzida.

Mas Plexure não me induz a pensar que essas músicas-materiais-composicionais seriam mera fabricação, instrumentalizações seguindo um cronograma de produção. Não se trata de reduzir os ganchos a uma narrativa de implantação, de imposição sutil e camuflada daquilo que deve ser familiar aos ouvintes, administrada por corporações e indústrias da cultura. Pois há algo de criação, de acontecimento nessas identificações, nessas singularidades musicais que remetem ao sentimento de comunidade, de integração e partilha. Mesmo que seja mostrada a possibilidade de que a diferença entre um hit e uma outra canção seja apenas a marca e as propagandas que a circundam, e a quantidade de tempo ao qual o ouvinte se viu exposto em cada uma delas. Uns dirão que não se passa de fabricação; outros, de que há acontecimento, singularidade significativa, apesar da fabricação. Em todo caso, o gancho, como experiencial, se mantém; e pode ser explorado.

Omaggio a Jerry Lee Lewis (1975), de Richard Trythall, começa com a frase: "All you gotta do honey" [tudo o que você tem de fazer, meu bem], e logo já se desconfia de Whole Lot Of Shakin' Going On, na versão de Lewis, lançada em 1957. O título da peça ajuda, é claro: a voz deve ser de Lewis. Uma pausa segue e anuncia que não há apenas a colagem, a presença do outro, mas uma expectativa de que a música-material seja manipulada, editada, separada. Esta pausa, por exemplo, já é uma intervenção, para que se pense no material usado, mas também no trabalho composicional que possivelmente virá logo mais. Segue "Stand in one little spot" [se posicionar em um pequeno espaço] e outra pausa. Parece certo que a música pensada é aquela mesma, em uma gravação antiga: resíduos sonoros indicam isso, embora não possam ser indicados com precisão. 
Seguem pausas intercaladas com "and then I want you to" [e então eu quero que você] e algo que soa como "Wiggle it around" [requebre por aí]. Nessas quatro frases há também manipulação do som. Ele vai da direita à esquerda: as falas estão duplicadas. A fala mais à esquerda, um pouco atrasada, provoca a sensação de movimento, contrastando já com a convenção de que uma voz de apresentador deva estar fixa, no centro do panorâmico. A parte falada, costumeiramente realizada no meio da canção de Lewis, dessa vez vem no começo: dá sinais de deslocamento e desconstrução. E quem requebra e dança primeiro é o próprio material musical, granulado em pequenas partículas de cerca de 0.1 segundos, movimenta-se rapidamente no panorâmico, do centro para as extremidades, mas não exatamente direcionalmente. A música original começa então sem alterações. Trythall aproveita o característico gesto de bateria, uma das anacruses comuns ao estilo do rock'n'roll em seus primórdios, para fazer com que seu gesto eletroacústico, começado anteriormente, acabe exatamente à entrada do grupo instrumental, tocando a base da música. Os sons de bateria, por seu caráter percussivo e pontual, se misturam de modo interessante com a granulação: um possível exemplo do familiar e do desconhecido, colocados lado a lado, em harmonia. Mas há outros exemplos. Logo em seguida é estabelecida uma sequência ritmico-harmônica estável, na região central do panorâmico, e a música Whole Lot Of Shakin' Going On prossegue sem distúrbios. Ela compõe uma camada, uma base sobre qual a camada de gestos granulados traça arcos: gestos de entrada e saída, grãos dispostos nos extremos do panorâmico, se intercalando de modo movimentado, propositadamente impreciso. Quando entra a voz de Lewis na camadabase a granulação já recedeu, e quando a voz sai, há como uma abertura de um espaço, que é aproveitada - ocorrem os gestos granulados.

No segundo 48 a voz inicial é retomada e a textura granulada se densifica, adquirindo maior variedade nos tipos de grãos sonoros, usando fragmentos de voz transpostos para o grave, movimentos majoritariamente da direita para a esquerda, e porventura adquirindo um ritmo pulsante, mais estável, uma energia de dança: a associação com o rock estado-unidense e o chacoalhar do final da década de 1950. Enquanto isso, há mais um elemento familiar: um ostinato derivado da levada de guitarra; ele vai e vem, como uma presença distante, difusa, por vezes abafada, por vezes como que imaginada. Há toda uma brincadeira com essas camadas e elementos que não comentarei. $\mathrm{O}$ importante é notar a existência constante dessa estratégia de garantir que o material familiar e suas características, também familiares, forneçam algo ao qual se 
agarrar ao ouvintes não acostumados com gestos de música eletroacústica, enquanto operações de granulação, sobreposição de camadas, filtragens, repetições e transposições são feitas, enquanto gestos no panorâmico são traçados, enquanto intensidades e dinâmicas a princípio estranhas ao rock'n'roll entram e saem, sem que exista, de fato, atrito entre aquilo que é familiar e o que não é. Cito mais um exemplo: em 3'21" ouve-se a música de Lewis, aparentemente sem alterações, cantando o gancho: I said shake, baby, shake [eu disse balance, baby, balance]. Daí até 3'59" segue uma série de versões desse trecho, filtrado, editado, cortado e por fim acelerado e transposto o som-palavra shake para o agudo até um corte, que confere a esse acelerando um arco gestual muito bem delineado. Ou seja, o gancho, como algo extremamente familiar, permite que o ouvinte possa se concentrar nas manipulações deste, nas operações de outro tipo de música aplicadas ao gancho. Como disse o compositor, em uma nota de programa, "é um ato de homenagem não apenas à ilimitada energia do Rock'n'Roll dos anos 1950, mas também à atmosfera divertidíssima meio 'Sputnik' que permeou a música contemporânea daquela época." (TRYTHALL, sem ano).

Sobre a Pausa 04 (2006), de minha autoria, se apoia estritamente sobre a noção de gancho, e como articulá-la a partir da criação de contrastes. Há dois tipos de material nessa obra eletroacústica. $O$ primeiro consiste em sons advindos de um mensageiro dos ventos de madeira e uma calimba, tratados com aumento de reverberação, a fim de criar uma profundidade de espaços sonoros e com filtros, criando uma sonoridade mais homogeneamente escura, com pouca energia nos parciais espectrais agudos. O segundo tipo consiste em fragmentos-ganchos de canções de sucesso comercial diversas, escolhidos procurando observar o critério da máxima reconhecibilidade das fontes musicais no menor tempo possível, preservando a trajetória gestual do fragmento. Estes aparecem ora sozinhos, ora encadeados de modo a formar frases, em que é procurada uma continuidade gestual, decidida caso a caso, dependo da sequência de amostras. A peça começa com amostras e frases de músicas brasileiras (a primeira entrada de música do tipo dois, se dá com Conceição, com Cauby Peixoto cantando, encadeada com Morena Tropicana, de Alceu Valença) combinando-as depois com sucessos internacionais.

No meio da peça há uma pausa digital - que sempre dão a dimensão da escuta do espaço em uma música eletrônica como uma construção, pois mostram como é possível 
apresentar uma ausência de espaço sonoro. Logo surge o glissando de piano de Dancing Queen, do grupo ABBA. No segundo tempo do seu subsequente acorde sustentado de lá maior, o acorde de Only You (and You Alone) irrompe, na versão de The Platters, interrompendo a canção do ABBA. Como a música segue com uma pausa após o acorde, há justamente o tempo necessário para o famoso arpejo de lá menor de Starway to Heaven, do grupo Led Zeppelin, do lado esquerdo do panorâmico, conforme o fonograma original (construindo assim um jogo maior-menor com o acorde tocado pelo grupo ABBA). Quando Tony Williams começa a cantar Only you já não mais se ouve a guitarra acústica de Jimmy Page. A amostra de The Platters é então abruptamente cortada, e com menos intensidade ouve-se Estoy Aquí de Shakira, com o inconfundível timbre de sua voz cantando o verso "Y ahora estoy". A frase é encavalada com uma irrupção de Barbie Girl, uma canção dance do grupo Acqua, por sua vez interrompida após o final da pronúncia de Barbie, para deixar fazer-se ouvir outro glissando descendente característico, aquele da entrada de Wicked Game, de Chris Isaak, em uma guitarra tocada com slider, começando em si bemol. Nesse momento, o primeiro tipo musical retorna, e a calimba ataca, sincronizadamente, a mesma nota que a guitarra do grupo de Chris Isaaks, o fá. Esta nota fá é também interrompida no caso da amostra musical utilizada, restando apenas a ressonância da calimba.

A partir do primeiro tipo musical, a peça opera ora sobrepondo ora intercalando os dois tipos musicais. Partindo de texturas calmas e escuras, sons percussivos e uma linha melódica de caráter improvisatório, e relações de profundidade entre os tambores e a calimba, passa-se pelos ganchos que devem, aos que os reconhecem, atuar como imagens sonoras rápidas, concatenadas de modo cinemático, funcionando como clarões de reconhecimento, fragmentos de memória trazidos à tona, memórias presentificadas. Essas sequências de amostras são mais chapadas: as gravações utilizadas passam rapidamente, não permitindo apreensão das variações dinâmicas; ademais, no campo da música pop, da qual a maioria das amostras advém, é frequente tanto mixagem com compressão, menos variação de intensidade e espaço sonoro, quanto uma maior uniformidade na própria execução musical.

E então, após algumas explosões de imagens hiper-reais, recede-se a uma realidade sonora mais onírica, de novo ao tipo musical primeiro. E mesmo que, nas transições de um para o outro, algum gesto seja aproveitado (por exemplo, a já mencionada sincronização de ataques usando uma nota comum aos dois tipos musicais), 
a ambiência sonora é muito díspar: não há casamento espectral, nem de tipos de reverberação.

\subsection{Pastiche}

Há o gancho, decerto. E no entanto, há outras nuanças. Para aqueles que não conhecem o repertório de sucessos da primeira década do CD, isto é, de 1982 a 1992, pode não haver gancho algum em Plexure. Entretanto um sentido de familiaridade se mantém, embora de fato mais genérico: combinações de timbres, formações harmônicas, deixas rítmicas, modos de tocar e cantar. Esse sentido pode ter ou não o sentimento de especificidade quanto à canção colada: uma percepção vaga de que há algo singular, possivelmente único, naquilo apresentado - no timbre da guitarra, em certos sons guturais, ao final da pronúncia de uma palavra.

Um compositor pode evitar deliberadamente essa colocação da singularidade e se concentrar na exploração do pastiche, de uma sensibilidade própria ao que já é uma reapresentação, uma segunda vez. Uma sensibilidade do reconhecimento que há uma aplicação de convenções, um modo de fazer que dilui sua própria singularidade, que procura anular seu acontecimento, que adota a estratégia de apresentá-lo como uma imagem de um acontecimento, um simulacro sem original. Buscar o que se aproxima de um absolutamente genérico - gestos desgastados, fórmulas repetidas à exaustão, arranjos espectrais, timbrísticos e instrumentais batidos etc. Afastar-se do singular, mas também daquilo que foi elencado como o representante máximo, que foi individualizado, que tem um nome ao qual as pessoas referir-se-ão para designá-lo.

Se uma história da composição pode ser feita a partir da noção de incorporação de ruídos, há todo um ruído urbano formado por canções genéricas, músicas ambiente, músicas de fundo, fracassadas aspirantes a hit. Numa inversão memorável, Merzbow já mencionara que se ruído [noise] significasse "som desconfortável", então, para ele, a música pop seria ruído ${ }^{126}$. O que leva à constatação já feita de que o gênero noise [ruído] já pode ser encarado como música. Da mesma forma, todas ruidagens advindas de técnicas expandidas e tratamentos não usuais dos instrumentos musicais já teriam sido

126 Há diversas menções a uma entrevista com Oskar Mertalo no zine eletrônico Corridor of Cells, 1997. A página correspondente, entretanto, encontra-se fora do ar. A citação pode ser encontrada em (POZO, sem data). 
em parte musicalizados - a obra de Lachenmann, já consagrada, seria exemplar nesse sentido. E no entanto, a partir de um certo momento (e em Ein Kinderspiel (1980), para piano, isso é claro), Lachenmann voltou a usar gestos de música tradicional - pequenos ritmos, arcos melódicos. Pergunto até que ponto esses ritmos e arcos melódicos não teriam virado ruído; não estariam também, tal qual a música pop genérica, atenuados na escuta, por um excesso de familiaridade, não seria barulho. Nesse espírito que Kreidler mencionará: "Eu gosto de fazer música ruidosa [noise music]. Música pop é ruído [noise]. É mais ruidosa que arranhar violinos hoje em dia. (...) A música concreta pegou sons cotidianos e os musicalizou. Eu pego música e a musicalizo." (KREIDLER, 2010, tradução nossa). Da mesma forma que outrora os sons de locomotiva e motores indicavam presença humana, onde antes se ouviria o vento e sons de animais, indicando natureza, uma vez que esse tecido musical da música pop passa a ser um dos principais indicativos de presença humana, da dominação do homem sobre a natureza (sobre o não-humano?), essas músicas não precisam mais ser escutadas. São índices de ocupação, de estabelecimento de um território. Kreidler continua: "Hoje em dia não há dúvida que ruído [noise] pode ser música. A questão é se um hit pode ser música”. (idem). Pois ele, em suas composições, evitará sistematicamente o uso de hits nos seus trechos em que há a possibilidade de reconhecer as fontes musicais. Possibilidade de reconhecimento garantida pela duração maior das amostras e a pouca transformação sonora a que foram sujeitas, mas prejudicada pela dificuldade de colocar um nome próprio em algo que é genérico, que tem nome de um estilo, de uma maneira de preencher o tempo, mas não é uma expressão individual. O hit resiste à musicalização que Kreidler busca, por conter ganchos específicos a ele. Uma musicalização que traça perguntas: apesar de ser uma colagem musical, e soar como tal, posso dizer que se trata de uma citação? Citar algo tão genérico assim? Afinal enxergamos pastiches em vários lugares, temos desenvolvido uma escuta, uma visão que identifica um material a ser utilizado num estilo, numa maneira de fazer. E esses modos de fazer, esse material, não foram incorporados à linguagem?

Harry Lehmann, no seu artigo Avant-garde Today: a Theorical Model of Aesthetic (2006), traça uma periodização da história da arte de acordo com uma tripartição teórica entre meio, obra e reflexão. Neste texto Lehmann procura manter a ideia de que há uma direcionalidade histórica para a arte, estipulando essa direcionalidade por uma progressiva diferenciação da arte enquanto sistema autônomo. O que interessa a este estudo é que, segundo Lehmann, é com o período pós-modernista da arte que o próprio 
meio artístico se torna um material a ser utilizado. É nele que o repertório do artista criador passa a incluir a perspectiva de que os diversos estilos, fórmulas, gêneros, bem como formas de propor um entendimento de arte, sejam materiais à disposição, a serem trabalhados: "Estilos artísticos passados se tornaram identificáveis como estilos, e conforme o estilo citado era liberado de sua antiga função - nomeadamente a constituição de uma obra - era também possível incorporar diferentes estilos numa mesma obra" (LEHMANN, 2006, p. 25).

Com o pastiche, a perda do potencial crítico em relação às fontes musicais específicas utilizadas é contrabalanceada por um ganho quanto à possibilidade de tecer relações críticas mais genéricas com as diferentes formas já estabelecidas de fazer e de entender música.

\subsection{Temporalidade}

Existem softwares que simulam os ruídos produzidos por alguns tipos de vitrolas, quando tocam discos. Simulam os resíduos do equipamento, os pequenos ruídos, os pops e plocs. Produzem o som indicador de uma vitrola, o som que denunciaria o suporte utilizado (o disco), bem como o equipamento de reprodução (a vitrola), antes da etapa de regravação, ou da etapa de remontagem, que usa o fonograma, o qual conteria aquele som indicador como suposto resíduo. Suposto pela possibilidade crescente de fabricar os resíduos, os indicadores. Narrar a liberação das sonoridades: liberação de seus contextos originais - liberar a sonoridade de um fita cassete torcida, com sua característica filtragem e momentos de distorção em que a gravação nela contida é transposta para o grave e de volta ao agudo - e a possibilidade de controle e de exploração referencial: artificialmente criar uma sonoridade que indique referência a um suporte, um processo fonográfico específico, uma mistura inexistente de processos fonográficos, transições entre eles etc.

Imagino que esses indicadores dos processos fonográficos específicos possam vir a ser simulados com exatidão - e então não mais simulados, mas criados como mais um parâmetro de manipulação possível. Mantendo a possibilidade de reconhecer nas sonoridades o que há de indicado por estes sons-indicadores, pode-se traçar uma linha temporal ligando os tipos de sonoridades mais os resíduos sonoros a certas épocas, certas etapas históricas, que correspondem, embora difusamente, a etapas no desenvol- 
vimento da fonografia. Esse traçado, por sua vez, permitiria uma arqueologia sonora reversa, em que poder-se-ia sobredeterminar sonoramente a temporalidade à qual uma amostra pertenceria, em termos de indicadores-sonoros. Reescrever certas determinações, reescrevendo o passado sonoro, seus resíduos, colocando amostras historicamente subsequentes como antecedentes, em termos de percepção sonora, fabricando gravações apócrifas, potencialmente realizadas a pouco, e referências sonoras a combinações de mídias e processos de (re)gravação.

Devo então atribuir ao som a possibilidade de referenciar temporalidades históricas. Se as diferentes tecnologias usadas nos processos fonográficos deixam traços, e passa a ser possível fabricá-los, então há a possibilidade, além-som, de que esses traços fabricados sejam escutados como referencias àquelas tecnologias, ao emprego delas. Essa possibilidade poderia ser rapidamente assimilada dentro do campo instrumental musical e esquecida enquanto referência (tal como as determinações "som de flauta", "efeito flanger", "massa complexa variada iterativa"127, "vibrato" etc. não são extrarreferenciais). Isto é, poder-se-ia dizer que é um som que tem como fonte sonora um toca-discos com um disco de vinil um pouco sujo, tocando certos sons, ou ainda, que trata-se de um som de flauta gravado em ORTF numa sala pequena tocado por um tocadiscos antigo, daqueles de maleta. Não obstante, sabendo que existem certos complexos de caracterizações sonoras muito comuns a etapas específicas no desenvolvimento da fonografia, pode-se também atribuir ao reconhecimento destes um aspecto referencial: tais cortes de frequência, tais ruídos residuais, tais mixagens - indicam temporalidades.

No vídeo compilado por Erik Carlson, Beethoven's Eroica: Opening Chords (2012), é realizado um mapeamento cronológico de várias execuções dos dois primeiros acordes da Sinfonia No. 3 (1804), de Beethoven. Nele, o autor justapõe várias amostras desses acordes, tal como tocado por orquestras específicas, com regentes específicos, em anos específicos (CARLSON, 2012). Da Berlin State Opera Orchestra, regida por Oskar Fried em 1924, seguindo com a Berlin Philharmonic, regida por Hans Pfitzner em 1929, à Vienna Philharmonic, com Felix Weingartner, em 1936, passando pela NBC Symphony, regida por Arturo Toscanini em 1938, chegando, após muitas outras, na Gewandhausorchester Leipzig, regida por Riccardo Chailly em 2011. A estratégia usada é clara, porque didática. Primeiro, mantém-se um elemento fixo bastante definido - os acordes de abertura de uma das sinfonias mais executadas na história da música orquestral, tocados

127 No estilo do Solfejo do Objeto Sonoro (Schaeffer, 1967), versão em português de Conrado Silva. 
por orquestras (uma formação que permaneceu relativamente estável desde o começo do século $X X)$, gravada sob a ótica do registro fiel ao que está sendo tocado, sem grandes intervenções na etapa de mixagem. Depois, justapondo as amostras, mostra-se como há uma série enorme de variações, que podem ser facilmente comparadas umas com as outras, dada a a média de duração, pequena, do elemento escolhido (os dois acordes iniciais). Por fim, colocando em sequência cronológica, mostra uma trajetória em que se evidencia a possibilidade, não imediata e nem linear, mas existente, de reconhecer as temporalidades específicas indicadas nos sons dispostos.

Chegando a esse ponto, torna-se necessário especificar: não são apenas os fatores fonográficos que compõem essa referencialidade temporal. Tipos de ataque, duração da nota (e sua relação com o tipo de sala cuja orquestra habitou, com sua taxa de reverberação específica) e diferenças de afinação também fornecem informações para esse tipo de determinação - de uma arqueologia sonora. Entretanto, essa relação não é direta e envolve um trabalho de decifração. Muito possivelmente, dada as variações mais extremadas resultantes da abordagem idiossincrática de cada par regente/orquestra, seria necessária uma amostragem muito maior de gravações para que se possa verificar quão eficaz seria uma correspondência entre qualidades e resíduos sonoros específicos e o ano de gravação das diversas interpretações.

Charles Dodge, em Any Resemblance Is Purely Coincidental (1980), para eletrônica e piano, não só restaura como também ressintetiza trechos de uma gravação de 1907 de Vesti la Giubba [vista sua roupa/fantasia], de Ruggero Leoncavallo, retirada da ópera Pagliacci (1892), cantada por Enrico Caruso. A peça começa com a percepção de que há algo de muito antigo, um som apagado e distante, mesmo com a potência da voz operística de Caruso. Com a entrada da parte de piano, em um som límpido e muito bem definido, vê-se que a gravação que se está a escutar é recente (trata-se de um CD lançado em 1992). Há dois mundos então: o do instrumento acústico piano e o da gravação antiga tocada e manipulada por um computador, ambos gravados nesse fonograma ouvido agora. Se, a princípio, a música de Leoncavallo pode ser rotulada de ópera romântica italiana, o piano, por sua vez, recebe o rótulo de instrumento de acompanhamento. Realiza harmonias, acompanha cantores em ensaios e, na falta de um conjunto orquestral disponível, em apresentações de árias. Esse papel é mantido durante boa parte da peça, alternando com jogos de imitação em que o piano e a gravação manipulada, na qual a voz é proeminente, também se alternam. 
Há uma pequena inversão logo no início dessas figurações melódicas imitativas: o piano toca uma linha melódica desacompanhada, enquanto a voz se multiplica, realizando acordes. É claro, não se trata do instrumento voz, mas da fixação sob suporte de uma execução do instrumento computador. A música de Dodge, ao basear-se em notas organizadas em gestos simples (os pequenos motivos atonais) e caricatos (as escalas que correspondem ao som estilizado de risada em Pagliacci), evoca uma maneira de fazer música ligada à fase da música eletroacústica em que muitos compositores se voltaram para a exploração das possibilidades oferecidas pelo protocolo MIDI. Que essa música computacional baseada em nota, predominantemente estado-unidense, da década de 1980, possa assim ser rotulada, permite localizá-la historicamente. Pois as informações ligadas à percepção de localizações temporais, tanto do romantismo da ópera quanto do aspecto arcaico da amostra musical utilizada, somam-se àquelas da própria obra (de uma fase da música eletroacústica) e de sua gravação (usando uma tecnologia mais recente e transparente). Em que pese a caracterização como obra eletroacústica, o compositor mesmo a deixa clara em três momentos, em que aplica um filtro ressonante com reverberação excessiva, a Vesti la Giubba, em 3'08, 5'26" e 7'09", fazendo-a soar distante e irreal, com ressonâncias de sino.

Adorno, em Teoria Estética (2008), se referiu à possibilidade de determinação histórica como um momento da obra de arte "autêntica", sua heteronomia social. Escreve ele:

O momento histórico é constitutivo nas obras de arte; as obras autênticas são as que se entregam sem reservas ao conteúdo material histórico da sua época e sem a pretensão sobre ela. São a historiografia inconsciente de si mesma de sua época; o que não é o último fator da sua mediação relativamente ao conhecimento. É isso precisamente que as torna incomensuráveis ao historismo que, em vez de seguir o seu próprio conteúdo histórico, as reduz à história que lhes é exterior. (ADORNO, 2008, p. 277).

Isto é, cada música "autêntica" já carrega consigo as determinações que permitem localizá-la em um período histórico, umas em relação às outras: intermusicalidades que acabam por indicar a colocação da obra em um contexto original específico, segundo um desenvolvimento específico da linguagem musical. $E$ isso é complementar ao seu caráter de autenticidade, ao modelo da obra de arte segundo seu caráter monádico, da obra 
como um pequeno mundo autocentrado, a valorizar aspectos de sua autossuficiência. Na arte que segue um plano de desenvolvimento modernista, as condições de desenvolvimento técnico da época, bem como aquelas em relação ao material e ao meio (os tipos de compreensão e as convenções existentes, que moldam o campo de possíveis), são constitutivas das próprias obras: "A história é imanente às obras, não é nenhum destino exterior, nenhuma avaliação flutuante." (idem, p. 290).

A inscrição da história, traçada a partir do caráter técnico-construtivo presente em cada obra (sua estruturação, seus meios, a maneira como articula esses meios), da evolução das formas estéticas no interior da linguagem musical, apresenta-se como material, operado a partir dos indicadores-sonoros e indicadores-estrutura presentes nas obras. Assim, não há uma operação de conversão, subsunção ou redução dos sons e estruturas em informações históricas, de localizações temporais mais ou menos vagas. Há antes o acoplamento de um núcleo histórico, acessível através desses indicadores, presentes nas obras. Mas não apenas nelas, e sim também em suas partes, seus fragmentos.

Nas colagens musicais, eventualmente percebe-se um caráter holográfico quanto às amostras: o quanto a parte carrega informações sobre o todo, ou, mais realisticamente, o quanto uma parte tem como potência evocar o todo; ou ainda, disparar memórias quanto a informações e qualidades do seu todo, memórias que os ouvintes já possuem. A obra, comparada com um pequeno mundo, também pode ser comparada com um personagem, agrupado em seu nome: como todo bom personagem, aspectos de sua caracterização e sua história (suas peripécias, desventuras, sua narrativa) são dificilmente separáveis. Em sua complexidade, a amostra da obra confunde-se com um momento da obra e se coloca à escuta como presença daquele personagem. Pode-se então localizálo, inclusive historicamente.

É diferente, entretanto, a colocação de uma obra e a colocação de um fragmento desta, bem como é diferente colocá-la em seu contexto habitual ou deslocá-la, des ou recontextualizá-la. Pois as diferentes operações também indicam estados de disponibilidade material, de avanços técnicos e estéticos; deixam marcas, sussurram dicas para a eventual separação entre o contexto da obra que usa colagens musicais e as músicas da qual advêm as colagens. Assim, uma sucessão de fragmentos de períodos históricos diferentes indica um período, e as diferentes maneiras de tratar e encadear esses fragmentos dão dicas quanto à posição histórica daquela colagem em relação a 
outras colagens.

\subsection{Autores}

Para além dos autores da obra ou performance que utiliza colagens musicais, há os autores das músicas de onde as amostras foram retiradas. Há uma série de maneiras de lidar com essa multiplicação de autoria, e ocultá-la é uma delas: já mostrei como $O$ Chá, de Del Nunzio, o faz. A falta de outros exemplos atesta, talvez, não tanto a inexistência de obras que realizem tal procedimento, mas a dificuldade de localizá-las, dado que escondem suas operações de colagem musical.

Outro modo é realizar músicas que se mostrem como colagens musicais, mas em que as autorias relacionadas a cada amostra sejam indetermináveis. Product Placements, de Kreidler, fica no meio do caminho: em sua parte musical propriamente dita, tenta fornecer dicas de que usa colagens musicais (em especial no gesto final), mas sente que precisará também desocultar o fato de que toda a peça foi constituída com colagens musicais - fá-lo através de meios não musicais, de declarações verbais e escritas de que a peça utiliza amostras musicais.

Essa indeterminação se dá pelo caráter excessivamente genérico dos fragmentos utilizados, seja por uma questão de escala temporal, em que eles têm duração muito pequena, como já abordado, seja por serem clichês, trechos absolutamente genéricos, que poderiam de fato pertencer a inúmeras músicas. Se dá também pela existência de transformações que não permitem mais determinar como era a amostra original.

A indeterminação pode ser dada como condição definida: a impossibilidade de determinar os outros autores, sem recorrer à própria lista de músicas utilizadas, aos rascunhos dos processos de composição, às próprias mídias manipuladas. Ela pode, de outro modo, aparecer como resultante de um tipo de ênfase sobre a apreensão da música, quando as diversas autorias se perdem numa noção de conjunto, de um conjunto de autores outros. A música se mostra como colagem musical - há todos os indícios presentes. As outras autorias, entretanto, não são colocadas como importantes; existe um empuxo na própria música a nos sugerir que precisar os autores seria mero capricho, no que concerne à escuta da música. $O$ trabalho do autor atual, sua colocação como o autor 
da colagem musical é o que importa, com relação à autoria. As operações que ele realizou, o trabalho de edição, montagem, escolha de fragmentos, seus encadeamentos, a escolha de cada fragmento e como cada um desses contribui para o todo.

Diria um guitarrista, de sua guitarra, o que importa é o que se faz com ela. De certa forma, uma das principais estratégias para criar esse sentido de indeterminação é imbuir uma noção de instrumentalidade musical, autorreferencial, ao conjunto de amostras musicais e operações realizadas com elas: o que importa é o que se faz, sonoramente, com o sampler e os samples e não quem fez aquele conteúdo amostrado. A declaração de Richard Barrett, quanto ao trabalho do duo Furt, com Paul Obermayer, exemplifica bem essa linha de argumentação:

\begin{abstract}
Claro que somos conscientes de que os sons-materiais têm uma 'vida dupla' (como eventos sonoros 'puros' mas também como conotação). $\mathrm{Na}$ verdade, nossos sons-materiais funcionam mais como instrumentos (um pouco como a extensa disposição de instrumentos que um percussionista pode usar, mas mais extensa e não predominantemente percussiva) e/ou personalidade (uma vez que cada som sugere um modo de tocar e um modo de expressão) do que citações. (apud BIANCHI, 2005).
\end{abstract}

Assim é conveniente, embora não estritamente necessário, evitar amostras cujas fontes musicais sejam possivelmente familiares aos ouvintes. Noah Creshevsky, por exemplo, em Red Carpet (2005), oferece uma sequência de fragmentos, claramente retirados de gravações instrumentais diversas. As operações que utiliza não levantam à escuta a pergunta em relação à multiplicação da autoria - apenas indicam que havia material, feito por outros, que foi cuidadosamente selecionado: gestos de arpejos ascendentes, escalas ascendentes e depois descendentes, figurações harmônicas cíclicas e acordes. Depois, tal como sons instrumentais são aproveitados, aproveitou-se as diferenças geradas pela heterogeneidade sonora dentro desse material, e com ele foi composta uma música. O fato de nenhuma gravação ser especialmente atribuível a um intérprete específico, e que os fragmentos são curtos demais para permitirem uma inferência quanto à composição da qual eles advêm, os torna convenientes e então tomados como objetos musicais, conteúdo para as frenéticas montagens de Creshevsky.

Há ainda mais maneiras. Pode ser possível determinar os autores das amostras, e isso bastar para uma série de jogos de deslocamento, ironia, comentário. Há uma 
multiplicação de nomes, como acontece àquele que se qualifica possuidor de um ouvido absoluto: escutar música nomeando elementos, aqui um fá, depois um sol, um lá etc, ali algo de autoria de Burzum, ali Marduk, possivelmente algo de Dark Throne ou Ulver. O número de elementos varia, e o número de elementos comuns a muitas músicas varia, pois é mais usual encontrar em músicas um fá ou outras notas musicais do que excertos de músicas de bandas conhecidas do black metal [metal negro], dos quais eu mesmo só posso citar um punhado de exemplos, ao passo que entre essas músicas dessas bandas, encontro notas fá aqui e acolá.

De qualquer forma, isso é ainda diferente da postura estética que consiste em concentrar-se em material advindo de um autor específico, por um período de tempo, ou por uma música inteira. Quando reconheço um longo trecho (por volta de dois minutos) de Parsifal (1882) de Wagner, em Wireless Fantasy (1960), de Vladmir Ussachevsky, sou levado a me perguntar por que Wagner, naquele contexto, junto a sons eletrônicos em ritmo de código morse, e com uma sonoridade de transmissão radiofônica. Com a insistência naquela música, também me pergunto sobre Parsifal, especificamente. Isso não me impede de ouvir sua sonoridade, em meio à composição, mas como não há outras músicas amostradas, é natural a procura de um motivo específico. No caso sou informado posteriormente, ao ler o texto de Beaudoin (2007), que se trata de uma homenagem ao pioneiro do rádio Lee De Forrest, cuja primeira transmissão teria sido a citada obra de Wagner. O compositor alemão havia declarado que sua ópera não seria tocada fora da Alemanha (o que foi obedecido para execuções instrumentais, até 1903). De Forrest possivelmente quis contrariar o dito de Wagner, ao transmiti-la via rádio. Ussachevsky, por sua vez, usou filtragens em uma gravação, muito provavelmente de 1951, para que esta fosse escutada como uma transmissão de rádio de ondas curtas, feita por De Forest. (BEAUDOIN, 2007, p. 143 e p. 146).

Outra obra, Pretender (1988), de John Oswald, tem como único material uma gravação de The Great Pretender [o/a grande fingidor(a)], lançada por Dolly Parton em 1984. A concentração tanto na música quanto numa gravação específica levantam questões. Aqui, como em boa parte do repertório da música pop, a autoria é muito mais de interpretação do que da canção propriamente dita. Fazer referência à autoria é também, nestes casos, tratar dessa diferença e compreender a colocação da autoria em cada contexto. No caso da canção, poucos atribuirão a autoria a Buck Ram, produtor de The Platters, mas alguns poderão dizer que a gravação é de autoria de Parton, e de que 
trata-se de um cover [uma versão] de um sucesso do grupo The Platters.

Para a obra, Oswald primeiro manipulou a gravação, variando sua velocidade de reprodução - o que provoca transposições de altura equivalentes: quanto mais lenta a velocidade, mais transposto ao grave resulta o som da gravação tocada; quanto mais rápida a velocidade, mais transposta ao agudo. Essa varação foi realizada usando várias técnicas e mídias: um tocador de fitas cassete de alta velocidade, um toca-disco especialmente flexível quanto às velocidades de reprodução, um gravador de rolo controlado a mão (CUTLER, 2004, p. 139). Depois, Oswald editou o material resultante e o mixou elaboradamente, mas manteve a estrutura da canção original, e seu sentido de progressão: a versão original se faz presente virtualmente, na forma da continuidade de suas partes. Assim, é possível colocar a ideia de uma escuta comparativa: comparar a obra com uma memória de como seria o original ou ainda com uma ideia especulativa do que seria o original (dado que se trata de uma estrutura genérica de canção bem estabelecida e por isso razoavelmente previsível).

O resultado procurou ser um comentário sobre a cantora/autora. Sua voz, quando transposta ao grave, soa como a voz de um tenor. A imagem da cantora como de uma boneca, uma mulher artificial, dá espaço a fantasias sobre o seu estatuto quanto ao gênero: poderia ser um travesti? O "vórtex de androgenia" (OSWALD, 2001, p. 15) que resulta da mudança de velocidade de reprodução da gravação de Parton é então explorado em forma de uma narrativa, de modo a conduzir o ouvinte pelas diferentes etapas do personagem (supostamente, da autora da amostra musical). Após uma apresentação em glissandos, e uma voz esganiçada, indicando o tom fantasioso e ilusório da obra, há como uma apresentação da cantora e sua canção, mas já progressivamente ralentando e se tornando mais grave, como alguém que suspeita de algo escondido (nessa personagem fingidora). Quando a voz soa como um homem, e a letra diz "/ seem to be what I'm not" [eu pareço ser o que eu não sou], há uma ruptura e consequente desdobramento da voz da cantora, para que ela possa fazer um dueto consigo mesma. A versão masculina, por ter duração maior, é editada, retirando as terminações das sílabas, de forma a sincronizar sua pronúncia com a versão feminina.

Ressurge a identificação do som com a autora ou sua personagem: se ainda soa como Dolly Parton, deve ser Dolly Parton. E então se está no campo da ilusão, no que a ilusão pode fornecer de sabedoria e verdade, ou, ao menos, no que através dela pode-se 
perceber e refletir sobre. Se o plunderphonics "fala apenas com a voz dos outros" (CUTLER, 2004, p. 143), Oswald fala com a persona de Parton, com sua personagem pública, com as camadas ficcionais que circundam uma musicista cujo estatuto de autora é público, cuja imagem, tanto quanto a música, circula nos diversos ambientes, e parece esperar que alguém se aproprie dela.

Trevor Wishart escreve sobre a elocução, como sons que criaturas produzem podem ser tomados como expressão delas, de seus estados internos, de suas reações ao ambiente e respostas à outras criaturas. "Em qualquer nível, o senso de elocução [utterance], seja como indicador, sinal, símbolo ou torrente sintática ou semânticosintática, entra em nossa percepção sobre os eventos.” (WISHART, 1996, p. 240-1). E continua, incluindo a prática musical humana em seu quadro:

Enquanto na tradição clássica o cantor se esforça para alcançar a perfeição de um tipo particular de voz, que é uma convenção social e que é tida como transferível de uma obra ou um contexto expressivo para outro (litúrgico, de concerto etc.), a música popular projeta as características idiossincráticas da voz individual do cantor. Considera-se que o público está mais interessado em música como elocução pessoal do que como uma elocução socialmente convencionada. Nós claramente não estamos lidando aqui com uma elocução direta, no sentido original do termo. $O$ cantor popular adota níveis múltiplos de estruturas de elocução convencionais para poder se comunicar com o público. Presume-se, no entanto (justificadamente ou não), que em algum nível o cantor não está 'atuando', que a convencionalização que o cantor está apresentando é sua elocução pessoal." (ibidem, 258-9, tradução nossa).

O autor expressa um estado interno. Há algo dele, de sua existência, algo real que foge às simbolizações e estruturações musicais. Eis o que o leva a ser identificado com as suas criações. Mais especificamente parece haver algo no som que é seu, possivelmente o timbre no que ele tem de não parametrizável, os resíduos sonoros. Algo que diga sobre ele, que o revele. Seria uma prática interpretativa que surge de um hábito de escuta relacionado à elocução? A relação com o autor de uma gravação, de um modo geral, passa de novo pela confusão relativa à percepção das marcas sonoras, dos resíduos específicos a um músico: essas marcas identitárias, que por vezes se mantêm, a despeito dos deslocamentos e transformações que sofrem as amostras, não garantem nem que a interpretação dela como elocução seja correta, nem que esta interpretação possa ser mantida quando da recontextualização dos fragmentos do autor. Entretanto, 
mesmo envolta por vezes em confusão, essa possibilidade abre espaço para diversas explorações criativas.

Em Rythm Science, Paul D. Miller (2004, p. 69) escreve: "Há um risco ontológico proposto quando se grava uma voz. A elocução gravada é o som roubado que retorna ao ser como uma presença do outro - esquizofrênica, alucinatória." Eu diria que há um risco sempre que se grava algo. Que essa gravação se apresente já, ao próprio autor do som, seu som como de um outro, de um que não mais é - e por fim, acabe por criar esse outro músico, figura de contornos mais vagos, alucinatória. Nesse fantasma da elocução podese colocar uma máscara e fazê-lo personagem de inúmeras outras aventuras.

\subsection{Comentários}

A utilização de procedimentos de colagem musical leva à reflexão sobre as músicas utilizadas, tanto quanto a utilização de outro tipo de material composicional leva a reflexões sobre estes. Como tratam-se de materiais que vêm de músicas, há um empuxo em direção a uma abordagem musicológica. Essa abordagem pode ser tão variada quanto o campo do que se convencionou como musicológico: desde avaliações analíticas das músicas utilizadas a argumentos sobre a função social destas, questões de gênero, acerca das tecnologias fonográficas, comentários sobre qualidades específicas e gerais, elucidação de diferenças significativas, apresentação de conceitos e teorias que unificam os modos de fazer.

Uma vez realizada a reflexão, resta concebê-la como uma série de procedimentos e prioridades, ou seja, aplicá-la ao fazer musical. Quando essa aplicação pode ser, além de ouvida (em seus diversos resultados sonoros), resgatada quando da escuta, tem-se como consequência a formação de uma camada textual junto à percepção, resultante da interpretação realizada no resgate: uma rede de sugestões, argumentos, comentários. A música se refere a uma camada textual, que por sua vez refere-se a aspectos envolvidos na música, sejam eles diretamente ou não relacionados a seus materiais, ou às outras músicas, das quais os materiais são formados (integralmente ou em parte). A análise musicológica não é apenas aplicada, mas referenciada: uma aplicação que aponta também para a própria aplicação; que informa que isso e aquilo foi aplicado.

Baby (2009), de minha autoria, nasceu de uma constatação: uma espécie de 
obsessão, no conjunto da obra interpretada pela cantora Britney Spears, pela palavra baby. Todas as ocorrências da palavra, nos seis primeiros álbuns de estúdio da cantora, foram colecionadas e separadas como material. A partir daí foram montadas em uma sequência que remetia à ideia de cronologia: a partir do primeiro álbum, seguindo a ordem da primeira à última faixa, depois fazendo o mesmo para o segundo álbum e assim por diante. Ajustes rítmicos foram feitos, de modo a encadear as amostras, enfatizando primeiro sua origem rítmica familiar (compassos quaternários com acentos previsíveis e pulsação constante dentro de uma mesma música), para depois montar frases com assimetrias e encadeamentos rápidos. A peça apresenta-se também como uma investigação da frequência de ocorrência da palavra nas canções interpretadas por Spears, com uma apresentação cronológica.

As obras e performances de Christian Marclay, colocadas em contexto, muitas vezes comentam o seu meio de escolha, o toca-discos, e sua mídia, o disco de vinil; procuraram desconstruir hábitos enraizados de tratamento destes. Yasunao Tone parece também dizer algo da falibilidade dos toca-CDs. Alexandre Fenerich, em Étude D'après Mahler (2004), ao sobrepor amostras de uma gravação do início da primeira Sinfonia de Gustav Mahler a sons de uma alvorada na floresta, propõe uma reflexão sobre dois modos de representar a natureza. O primeiro, a obra de Mahler, com sua notação na partitura: "Wie ein Naturlaut" [como um som da natureza]. O segundo, os sons da alvorada, evocando a obra de Murray Schafer, sons que dão a ideia de uma paisagem sonora. Ambas as concepções, a de Mahler e a de Schafer, têm a natureza como, segundo Fenerich "um lugar ideal, que se perdeu com a civilização; um lugar idílico." (informação pessoal ${ }^{128}$ ). Entretanto, tanto a formação orquestral para o período de Mahler, quanto os desenvolvimentos da fonografia, para o período de Schafer, são sintomáticos de etapas do desenvolvimento de uma sociedade ocidental industrializada. A música procura sinalizar então intervenções do que seria o artificial: as amostras de Mahler, gravadas de uma vitrola tocando em um vinil uma interpretação da obra, deixam escutar os ruídos do meio de reprodução, em pianíssimo. Depois, inserções de uma versão da mesma obra, realizada com um timbre MIDI, como era conhecido o do gerador de sons de uma placa Sound Blaster antiga: um timbre extremamente artificial. Estas inserções fazem ouvir as notas da obra de Mahler, muito pronunciadamente, no que há de convencionado, de artificial, de anatural nessas frases e articulações.

128 Fenerich, A. Mensagem recebida por <fenerich@gmail.com>. 
Não que se possa ou pretenda reduzir a obra de Fenerich a esse texto escrito acima. Ela, à parte os inúmeros detalhes de montagem, apresenta uma série de outras características. Entretanto existe a reflexão, e ela pode constituir uma das camadas da escuta da obra. Ademais, em uma composição do tipo estudo há geralmente a concentração da exploração de um aspecto do instrumento a ser estudado, ou uma configuração específica e como ela se relaciona com este instrumento. Fenerich, nessa obra, também estuda possibilidades de criação de texturas sonoras acusmáticas, a partir do primeiro movimento da Primeira Sinfonia de Mahler, em si atmosférico. Procura criar adensamentos espectrais e favorecer a noção de uma escuta envolta, metaforicamente, em névoa, em penumbras; realiza sobreposições cuidadosas de várias amostras do mesmo material, com diferenças de afinação entre elas.

Em outra passagem de Rythm Science, lê-se: "Selecionar, detectar, definir morfologias e construir estruturas, isso é o que faz a nova arte prosseguir. (...) flutar num oceano de possibilidades." (MILLER, 2004, p. 17). Seis anos depois, Alexandre Fenerich voltou ao referido movimento da sinfonia de Mahler para compor outra obra, bastante diferente, Surfing on Turntables (versão de performance, 2010). Em 2012, realizou ainda outra versão, para o disco virtual do duo $\mathrm{N}-1$ enemenosvideo (DUO N-1, 2012), com mudanças bastante significativas. Nas diversas vezes que entrou em contato com gravações em vinil da obra de Mahler, nas diversas escutas desse primeiro movimento, é possível que tenha pensado: pode ser de outra forma. Talvez seja esse o comentário lançado implicitamente pelas práticas de colagem musical, em relação às músicas: fazer dizer pode ser de outra forma. 


\section{Capítulo 4: Dois Temas}

Este capítulo apresenta dois temas, e os coloca em relação ao tema do trabalho como um todo. O primeiro mostra correlatos musicais para três das práticas das artes visuais apresentadas rapidamente no tópico 1.2. A transposição é feita também dos termos em francês para as versões aportuguesadas, presentes no título do tópico.

O segundo tema trata do período pós-moderno, estipulado a partir da noção de que seria marcado por um movimento de indiferenciação entre os campos culturais e econômicos, da música artística e da música de entretenimento. Isso de modo algum implica numa indiferenciação completa entre estes, mas sim em uma tendência, em uma desvalorização das visões que os separam categoricamente, de um enfraquecimento da postulação de alteridades radicais.

\subsection{Bricolagem, Assemblagem, Descolagem}

As gravações foram frequentemente tratadas como material encontrado, como objetos-achados. Por mais que, em seus Cinco Estudos de Ruído [Cinq Étude de Bruits], realizados em 1948, Pierre Schaeffer houvesse feito uso consciente e programado das tecnologias disponíveis, com fins de obtenção de material sonoro para o trabalho composicional (isto é, material virtualmente integrante de uma obra futura), em seu último estudo, Étude Pathétique, recorreu a discos presentes fortuitamente no seu local de trabalho. A mixagem dessa obra, no conjunto, segue o modo da bricolagem, de fazer com o que se tem à mão, de dar um jeito com o que se encontra disponível. Diz Schaeffer da ocasião:

Não me refreio, nesta véspera de embarque, de vir ao estúdio para uma última sessão. Arrisco uma chance final de resolver meu problema com as vozes.

A incorporação de elementos vocais há muito me tenta. Não disponho de atores, muito menos de cantores (não é que, há semanas,

nos viramos sem executantes). Existem sempre velhos discos abandonados que se amontoam pelo estúdio. Pego um ao acaso. É Sacha Guitry, juro! 'Sur tes lèvres', diz ele etc., mas a gravação foi cortada pela tosse da radialista, o que explica que o disco tenha sido descartado. Pego esse disco, coloco em outro prato o ruído muito tranquilo de uma velha e 
boa chata, depois, em dois outros pratos, o que me cai nas mãos: um disco americano de acordeom ou harmônica e um disco balinês. A seguir, exercício de virtuosidade nos quatro potenciômetros e nas oito chaves de contato.

Tudo tem suas compensações. O 'Estudo número cinco', dito 'das caçarolas' (pois apresenta, no início e no fim, uma sequência de lata em rodopio), nasce em alguns minutos: o tempo de gravá-lo.

Nos quatro estudos anteriores percebe-se 0 quanto 0 desenvolvimento deixa a desejar, o quanto o crescendo é desajeitado, os encadeamentos rudimentares. No 'Estudo das caçarolas', a chata dos canais da França, a harmônica americana e os sacerdotes de Bali passam a obedecer, milagrosamente, ao deus dos toca-discos, formam um conjunto traquejado, econômico no uso de seus efeitos, e quando intervém em alternância o lancinante 'Sur tes lèvres, Sur tes lèvres, Sur tes lèvres' entrecortado de tossidas, o ouvinte, sempre desprecavido, admira-se muito justamente de uma composição tão acabada, tão harmoniosa, tão definitiva. (SCHAEFFER, 2010, p. 20-1).

Russell Ferguson, ao tratar da obra de Christian Marclay, enfatiza a influência do readymade de Duchamp. Segundo ele, "Uma das inovações [breaktrhoughs] de Marclay foi a percepção de que gravações de música poderiam ser tratadas como uma forma de objeto-encontrado [readymade], e incorporadas diretamente em suas obras." (FERGUSON, 2003, p. 40). Ao contrário da tradicional definição do readymade de Duchamp, que envolve a eleição pelo artista de um objeto cotidiano como artístico, isto é, um ato de nomeação deste como arte, as colagens musicais manipulam o objeto. A prática de Marclay é melhor vista como bricolagem, onde o novo surge do arranjo e transformação do disponível e próximo ao artista.

Abundância de disponibilidade: discos jogados na rua, empilhados em lojas para Marclay na década de 1980. As várias gravações idênticas e baratas da Sinfonia No. 1 de Mahler, encontradas em um sebo por Alexandre Fenerich. As coleções particulares de CDs para o Mário Del Nunzio de O Chá e Improviso em Branco e Preto (Carta às Videntes) e o compositor John Wall, de seu período entre Fear of Gravity (1993) e Constructions I-IV (1999). Mas também escassez: Knížák e o transformar um disco já ouvido inúmeras vezes em outro, recortá-lo, colá-lo em outra configuração. Reciclagem de discos. O quanto para Del Nunzio e Wall o uso de CDs não assinala a escassez de possibilidades instrumentais e de sessões de gravação em estúdio? Para o Del Nunzio do Improviso, tal qual o James Tenney de Collage \#1 - ("Blue Suede"), trata-se de viabilizar a criação, de adaptar-se na falta de outras possibilidades: de ter instrumentistas à disposição, de conseguir se satisfazer com o estado da síntese eletrônica da época, respectivamente. 
Incorporar o modo das máquinas, coletar os objetos da indústria, recriar o fluxo incoerente da vida cotidiana, reanimar detritos e despojos. A indústria produz imagens e gravações em massa. Tal como uma imagem que aparece sempre, que se impõe dentro dos meios de comunicação, uma gravação de música que toca mais, que é mais veiculada, tem mais chances de ser apropriada. Ela estará mais disponível, apresentando-se aqui e ali à mão, como que à espreita de um bricoleur [bricolador]. Andy Warhol retratou diversos personagens já em evidência, como Mao Tse Tung e Marilyn Monroe. Não que não tivesse de produzir seus quadros, suas telas de seda [silk-screens]. As imagens, entretanto, já estavam lá, de certa forma cercando-o em sua vida cotidiana. Joel Chadabe inclui uma citação de François Bayle sobre a música concreta em seu livro Electric Sound: The Past and Promise of Electronic Music. Diz Bayle (apud CHADABE, 1997, p. 35):

A música concreta não era de modo algum uma música de ruídos, de modo algum uma música provocativa. Era o contrário. Era uma música que usava todos os recursos disponíveis, uma música que usa todos os sons da vida. Sons de música concreta têm significados para nós, assim como fotografias e filmes têm significados. Eles mostram a vida da forma como nós a experienciamos, como nós a vivemos no mundo cotidiano.

Da mesma forma que Pierre Schaeffer achou potencial musical nos diversos objetos sonoros da vida cotidiana e se apropriou destes, a fim de musicalizá-los, músicos diversos acharam potencial de renovação em músicas ouvidas em situações cotidianas. Ambos os projetos tinham como característica apresentar novas formas de escutar algo já escutado.

Da bricolagem para o acúmulo de arquivos e materiais disponíveis, típico da era digital, há uma inversão. Não mais usei porque tinha à mão, mas preciso usar porque estão aqui, disponíveis. Bombardeados, saturados e sobre-expostos a informações e estímulos delas resultantes, existe o risco de nivelamento, de sobrecarga por excesso, de diluição dos afetos. Ter e ouvir pode ser pouco, tantas músicas ouvidas e adquiridas. Quando se considera a informação como livre e imaterial, ou quase (há sempre computadores, servidores, cabos e torres de transmissão), para apropriar-se delas é necessário reforçar estratégias de uso. Depois de se sentir perdido no mar informacional, organizar seus arquivos, compartilhá-los, seguir o fluxo e disponibilizá-los, mas também valorá-los, construir hierarquias, colecioná-los, procurar maneiras de colocá-los em uso, as práticas de sampleamento e colagem musical sendo uma dessas estratégias. 
Assemblagens digitais: é relativamente fácil conseguir a discografia completa de um grupo, embora seja um pouco mais difícil procurar por todas as gravações das obras de um compositor. Colecionar estilemas: gestos característicos do artista. Com a disposição dessa coleção, mostrar que conhece e ouviu as obras, que tem propriedade sobre elas, que soube escolher os trechos mais característicos. Com o estilema, articular o reconhecimento quase imediato de um gesto e suas fontes musicais. Partilhar um traçado, um modo de lidar com a informação, de inserir-se no processo, de executar uma estratégia de uso. Todos os 177 gritos significativos emitidos por Michael Jackson no álbum Bad (1987), todos nomes de mulheres nas canções compostas e interpretadas por Chico Buarque, todos os gestos de crescendo em todas as gravações disponíveis da obra de Edgard Varèse, por exemplo.

Outra estratégia para lidar com o excesso é pensar o excedente quantitativo como nova qualidade. E então esse excesso não estaria a indicar a necessidade de uma superação dos modos humanos de ouvir, fruir e receber informações? Ter-se-ia de resolver o problema da diferença entre experiência e informação. Como transformar a experiência temporal de ouvir uma obra, em sua duração, em informação, para poder transmitir ao cérebro a Aida de Verdi, com a divina Maria Callas, entre um gole e outro de café. Mais do que uma experiência de compressão temporal, seria como uma criação ex nihilo [do nada] de uma memória. Rumo a uma reengenharia da memória. Se uma experiência longa não pode ser reproduzida em um tempo curto (problema da duração), talvez a memória dessa experiência possa ser rapidamente implantada em quem não a teve.

Compression Sound Art (2009) é um vídeo de Johannes Kreidler que lida com o excesso, tal como apresenta-se em uma cultura digital em que a internet exerce um papel importante. Ora aplica processos de compressão sobre grandes quantidades de arquivos digitais, ora diz aplicá-los: não importa tanto - a representação dessa possibilidade é mais importante que a ação concreta de compressão. De fato, o pouco tempo necessário para localizar e baixar arquivos é representado por formas de apresentação comprimidas temporalmente: 130.000 canções tocadas em quatro segundos; toda a faixa de áudio do filme Rambo 3 tocada em um terço de segundo; toda a faixa de áudio de um filme pornô tocada em um terço de segundo; a versão em áudio da leitura de Em Busca do Tempo Perdido, de Marcel Proust, tocada em um segundo; etc.

Aí já é sublinhada uma característica do meio digital: como tudo circula como 
arquivos e todos arquivos são constituídos por sequências numéricas, há um nivelamento no número. Tanto um filme de ação quanto um pornográfico parecem ser veiculados da mesma forma, e a leitura de Proust figura como áudio, tal qual os gemidos de um casal fazendo sexo. Nada de novo, mas na facilidade de navegar rapidamente pela internet, passando por conteúdos os mais díspares, o nivelamento música/produto é acelerado em outro: artefatos culturais/informação. Com a digitalização, tudo o que se apresenta como arquivo pode ser traduzido, transposto, transformado usando as mesmas regras, pois pode ser tratado como número. A nossa cultura, entretanto, não é tão niveladora, e Kreidler explora esses descompassos, apresentando uma compressão temporal também de um terço de segundo das leituras do Torá, da Bíblia, do Alcorão e da obra completa de Friedrich Nietzsche. A informação é comprimida e nivelada, mas e o significado particular de cada um dessas obras? Pode-se facilmente banalizar as manifestações tratando todas como iguais (apenas informações numa cultura das comunicações de massa [mass media]). Mas, embora o estatuto como imagem de "uma nota aguda, tocada pelo pomo de adão de um imigrante ilegal" seja o mesmo que "o código para ilegalmente extrair DVDs, lido como uma forma de onda" e que "o papa, tocado usando uma camisinha como membrana do alto-falante" (KREIDLER, 2009), os significados são claramente diferentes. Há, é claro, uma dessacralização, o lado positivo desse nivelamento ${ }^{129}$, um incentivo a tratar da mesma forma diferentes símbolos. Estabelecer um tratamento similar ou igual a estes é uma estratégia que pode colocar em evidencia os descompassos culturais entre eles.

O vídeo começa primeiro descrevendo em palavras o que supostamente os sons a serem tocados seriam. Depois, apresenta-os acompanhados de uma imagem icônica. No caso de Proust, um quadro do episódio 31 de Flying Circus, do grupo Monthy Python, em que se lê: "Concurso de toda a Inglaterra de Resuma Proust". Após algumas apresentações de objetos sonoros, Kreidler passa a combiná-los, já sem o texto descritivo. Nessa etapa há a suposição que o público já tenha guardado o que cada par som-imagem representam/são. Na segunda etapa só são apresentadas as imagens, ritmadamente: "Misture! Agora você pode imaginar os sons na sua cabeça." Como em um computador, o ouvinte acessaria os sons a partir de ícones, ou ainda, os ícones são as formas informacionais comprimida sdaqueles sons-imagens, formas que seria descomprimidas pela memória de quem as acessa.

129 Positivo porque promove a criação e um aumento aparente das possibilidades de exploração dos elementos. 
No final da obra os diversos objetos-sonoros são utilizados como amostras para tocar a melodia da canção Noite Feliz. São homogeneizados pela noção de nota - cada um usado como uma classe de nota na execução da melodia (o que Oswald chamou de klangprobes). Nesse momento há também um descompasso: as diferenças de origem do som, as diferenças referenciais destes, aparentemente irreconciliáveis entre si, contrapõem a promessa de felicidade cristã da canção.

Nas descolagens [décollages], quando um cartaz é rasgado, danificado, deixa entrever um cartaz colado atrás, que foi sobreposto, ou ainda, seu fundo, seu suporte - a textura do poste, do muro, da placa de madeira em que foi afixado. Mesmo durante o período em que operava a cultura da cassete, quando se gravava em cima de outra gravação, na mesma fita, esse processo apagava a informação anterior, não permitindo a construção dessas camadas. Pan\&Tone costumava tentar recuperar arquivos de música, entre outros tipos, deletados propositalmente de um HD, usando um software antiquado que acabava por distorcer as informações e gerar arquivos de ruído misturado com trechos dos arquivos de música. Peter Francis Tribute (2009) foi assim gerada ${ }^{130}$.

Mieko Shiomi usa um ferro de solda para danificar um disco em diversos pontos, na obra Amplified Dream No. 1 (1969). Em Water Music (1965), utiliza um disco coberto de cola, ao qual se adicionava água para lavar a cola solúvel, enquanto o disco é tocado; em uma performance de 1965 envolveu, a título de exemplificação, uma gravação de $A n$ Invitation to Waltz, de Carl Maria von Weber (Kelly, 2009, p.121). Tem-se nesse processo desde um disco que não soa até um disco que toca com razoável fidelidade, em relação ao seu estado inicial, cheio de cola. Otomo Yoshihide, em colaboração com Mats Gustafsson e Mikito Ozeki, produziu With Records (2009), em que uma série de discos de vinil contendo gravações de Gustafsson tocando saxofone são cobertos por uma camada de papel. Esta camada é recortada por Ozeki, produzindo vários desenhos, que também produzem as trilhas que a agulha do tocador percorrerá erraticamente ao tocar o disco. Cut out = décollage. Colar por cima e então retirar a camada para fazer soar.

Louis Andriessen, em In Memoriam (1971) adiciona silêncios à gravação de uma versão dançante e brega do início do primeiro movimento da Sinfonia No. 40 (1788), de Wolfgang Amadeus Mozart. A música soa inteira engasgada, truncada. A escuta acaba

130 Obra integrante do álbum virtual, uma coletânea de diversos autores, Bent Out of Shape. Estados Unidos: Free music Friday, 13 de março de 2009. Disponível em: <http://www.getlofi.com/?p=1607>. Acesso em: 02 jul. 2012. 
por antecipar as frases, pela simplicidade fraseológica da obra de Mozart e familiaridade com ela, e reforçadamente pelo fato de ser uma versão esteticamente kitsch, que possui batidas pontuando o início dos tempos. No entanto, a música não flui e a escuta antecipa à custa de esperar e aguentar o transcorrer dos fragmentos entrecortados. Como disse Christian Marclay, em outra ocasião: "Você sempre está tentando ouvir o original, mas ele não está exatamente lá" (GOTTSTEIN, 2008).

Fuga No. 3 de Bach/Busoni/Caesar (2008), de Rodolfo Caesar, tem como material uma gravação do movimento Fuga III, da peça para piano Fantasia Contrappuntistica (1910), de Ferrucio Busoni. A obra de Busoni, por sua vez, utiliza como material inicial $A$ Arte da Fuga (1750), obra publicada em formato inacabado após a morte de seu compositor, Johann Sebastian Bach. Esse movimento de Busoni continua o desenvolvimento contrapontístico da parte inacabada do Contrapunctus XIV de Bach, aquele em que o compositor apresenta o motivo B A C H (si bemol, lá, dó, si natural). Por Busoni ter usado como material a obra de Bach, a ênfase da abordagem da peça não recairia sobre a atitude de apropriação (que Busoni já tinha feito), mas sim sobre o processo sutil e lento empregado. Há duas camadas de manipulação, mas em vez de uma descolagem, o que ocorre é que Caesar realiza uma expansão temporal da gravação usada. Usando um granulador montado a partir da rotina FOG do software Csound, Caesar faz com que a gravação vá ficando cada vez mais lenta, vá se estendendo temporalmente cada vez mais. Com isso, os sons de piano, já alterados e pouco nítidos no começo, vão progressivamente perdendo de vez a definição de seus ataques, como se o objeto piano (a fonte sonora imaginada) estivesse também se dissolvendo. O contraponto, e depois mesmo as notas da composição de Busoni, vão se perdendo, dando lugar à percepção do som, das sutilezas do som, de sua continuidade. Como um cartaz que vai sendo ampliado até que os contornos sejam tão grandes que não se vê mais linhas, palavras, contornos, mas apenas borrões de cor.

\subsection{Período Pós-moderno}

Algumas características do repertório abordado na pesquisa parecem apontar para uma aproximação entre este e a discussão acerca da pós-modernidade e de relações possíveis com a música. Pergunta-se: qual a relação entre as práticas e obras abordadas 
nessa pesquisa e o pós-modernismo? A resposta para essa questão não pode ser concisa: existem várias concepções do que seria o pós-modernismo; apenas uma delas é levada aqui em conta.

Não é, portanto, tarefa desse tópico definir a colagem musical eletrônica como fenômeno pós-moderno ou da pós-modernidade, por excelência; antes, cabe a este tópico mostrar inclinações e encontros, e com isso contribuir para a reflexão sobre as práticas e obras abordadas na pesquisa.

Se há o período pós-moderno, então devem haver motivos suficientes para que seja diferente do período moderno, admitindo a existência de um período moderno. Em se tratando de um período que esboçaria suas manifestações a partir da década de 1960, e com mais força nas décadas de 1980 em diante, embora de modo desigual em diferentes localidades, seria adequado admitir que qualquer manifestação ocorrida neste período, pensada sob a ótica da periodização, necessariamente estabelece com ele uma relação. Isto é, se o pós-modernismo é uma grande categoria que se articula como condição histórica, então, para todas as manifestações ocorridas neste mesmo período, há uma relação para com ele.

Fredric Jameson trata do pós-modernismo em inúmeros textos. Em "Fim da arte" ou "fim da história" (2001, p. 73) insiste na tese de que a pós-modernidade seria marcada por uma progressiva indiferenciação entre o campo da cultura e o da economia: a cultura estaria orientada para a produção de mercadorias. Assim, no período pós-moderno, intensificado na década de 1980, haveria uma constante dificuldade de pensar o econômico e o estético como esferas distintas. Nesse sentido, distinções, embora sobreviventes, entre alta e baixa cultura, se fariam menos presentes; haveria uma tendência de subsumi-las no conceito de produto, associado ao comércio: o antagonismo moderno entre arte e cultura (cultura entendida normalmente como um equivalente de baixa cultura) seria absorvido pela noção de produto; a suposição de diferença de natureza entre os dois desvaneceria. Ambas as músicas da alta e da baixa cultura, ou ainda, a música artística e a música da cultura, são um tipo de produto - música -, e se diferenciam pelos modos de produção e circulação enquanto mercadoria. Assim, posturas que procurariam inviabilizar o tratamento da música como mercadoria, sob esse viés, seriam encaradas como atitudes de resistência à concepção dominante, ou, de modo depreciativo, resquícios modernistas antiquados ou arroubos românticos irrealistas.

De fato, para o Adorno de Teoria Estética (2008), devido às propensões utópicas 
presentes na origem da arte moderna, ela se estabelece através do antagonismo mencionado. Segundo Adorno, se é possível identificar um inimigo dessa ideia de arte, moderna, este seria a ideia de cultura (ADORNO, 2008, p. 16-21). Sobre essa postura, afirma Jameson (2005, p. 208):

Assim, de todos os lados, ergue-se a disposição de reduzir a cultura a um termo pejorativo: cultura é má cultura, é cultura de massas, é cultura comercial. (...) Então, temos aqui diversas identificações: grande literatura e grande arte significam o estético subtraída a cultura, o campo estético radicalmente limpo e purificado da cultura (que representa, principalmente, a cultura de massas).

Essas identificações não fariam mais parte do pensamento pós-moderno, como nota Huyssen (1991, p. 44): "A grande divisão que separava o alto modernismo da cultura de massas, codificada nas várias explicações e análises clássicas do modernismo, já não parece relevante para as sensibilidades artísticas e críticas pós-modernas."

No caso da colagem musical eletrônica há uma diluição dessa oposição, já que toda música é gravação (e potencial geradora de materiais), não importando sua filiação à esfera da arte (alta cultura) ou da (baixa) cultura. E mais: a reflexão que se estabelece através da consideração da referencialidade como um importante fator composicional contribui também para a valorização do contexto no qual as músicas se inserem (seus dados culturais). De fato, inúmeros artistas abordados parecem pouco se importar com esse antagonismo, ou então, a partir dele, trabalhar para a desconstrução de suas premissas $^{131}$.

Da ideia de que toda e qualquer música estaria disponível como produto, poder-se-

131 Stockhausen seria um contraexemplo, notoriamente por se filiar a um ideário alto modernista, ao menos quanto a seu discurso do grande artista, do gênio, antena de sua raça, da inovação, progresso e desenvolvimento dentro da linguagem da música. As declarações dele, em (STOCKHAUSEN et al, 2000, p. 382) confirmam essa asserção: "Eu gostaria que esses músicos [referindo-se Richard James, Richie Hawtin, Robin Rimbaud e Daniel Pemberton] não se deixassem realizar repetições, e fossem mais rapidamente desenvolver suas ideias ou seus achados, porque eu não aprecio nem um pouco essa linguagem permanentemente repetitiva. Eu acredito que músicos deveriam ter figurações bem concisas e não confiarem nessa insinuante psicologia [fashionable psychology]. Eu não gosto de nenhuma psicologia: usar a música como uma droga é estupidez. Não se deveria fazer isso: música é o produto da mais alta inteligência humana, e dos melhores sentidos, os sentidos da escuta, da imaginação e da intuição. E, tão logo se transforma apenas em um meio para criar uma ambiência, ou como nós dizemos, um ambiente, ou para ser usada por certos propósitos, então a música se transforma numa puta, e realmente não se deveria permitir isso; não se deveria servir a nenhuma demanda existente e em particular a nenhum valor comercial. Isso seria terrível: isto é, vender a música."

Sempre considerei a entrada dos acordes de Gruppen (1955-7), de Stockhausen, em meio a uma batida pulsante repetitiva, que remetia ao gênero de música eletrônica de pista tecno, em Improviso em Branco e Preto (carta às videntes) (2004), de Mário Del Nunzio, como um pequeno comentário irônico sobre essa colocação, razoavelmente conhecida, de Stockhausen. Del Nunzio, entretanto, negou tal intenção. 
ia extrapolar: qualquer música passaria a ser, virtualmente, manancial de materiais a serem trabalhados. No contexto do sampleamento, todas as músicas, desde que gravadas, passam pelo mesmo processo de virtualização, com um aspecto homogeneizador adicional: elas são gravações, são manipuladas como gravações e dão origem a gravações $^{132}$. É fortuito lembrar que é cada vez mais difícil pensar música como algo desvencilhado da ideia de gravação: quase todas as obras e performances musicais são, uma hora ou outra, gravadas. A não gravação de uma música, uma vez admitido esse cenário, passa cada vez mais a ser vista sob o prisma do descuido ou da resistência declarada ao ato de $\operatorname{gravar}^{133}$.

Dir-se-á então que gravações são produtos, e que, durante a prática da colagem musical, todas as gravações de música são materiais em potencial, ou ainda, reservas musico-sonoras: uma música é potencialmente fragmentos de música que são potencialmente parte de outra música. No limite, coloca-se uma armação sobre as gravações de música, como uma matriz musical, da qual é preciso selecionar, encontrar os melhores pedaços, localizar os pequenos acontecimentos, os possíveis encaixes e combinações. De música em música produzida, há a circulação incessante da produção. Ouve-se algo já pensando que dali poderão ser aproveitados trechos para outra criação. O fluxo de escuta é um fluxo de produção, fragmentado. Como um DJ a tocar em boates de música eletrônica de pista, ao escolher as melhores músicas, realizar as sobreposições e transições que, em seu novo contexto, reanimarão o material, funcionarão pra produzir um acontecimento, a dança, euforia, diversão. O caráter programado, funcional, talvez, nesse caso, espelhe uma lógica tecno-científica que vê a natureza como potencial ${ }^{134}$. Música como algo do qual se deve extrair os momentos que possam proporcionar o máximo de prazer, incitar à dança, promover a integração comunitária: totemismo nômade, de comunidades que se formam, se unem através do som, e logo após se pulverizam. No caso da produção do álbum Alterstill (1995), de John Wall, ainda são os melhores pedaços, as combinações móveis, o espaço combinatório, mudando sua configuração, seu campo de possibilidades, a cada acréscimo, a cada

132 No caso não eletrônico, interferem processos de notação e interpretação; a autorreflexividade do processo é menor, dado que envolve mais ações e decisões humanas.

133 Como é o caso de formulações musicais muito dependentes do momento da performance, ou de seu contexto específico. Nesse caso, como a gravação registra os sons, mas não o momento e a situação (o espaço, as pessoas, as decisões tomadas na hora, o humor), pode haver uma opção deliberada de não gravar.

$134 \mathrm{O}$ argumento é de Heidegger: um rio é enxergado como um reservatório de água, a ser usado para produzir energia elétrica via a construção de uma usina hidroelétrica (2007, p. 376). 
fragmento adicionado:

Bem, primeiro eu acumulo amostras. Elas vêm principalmente de música clássica do século XX e ocasionalmente de avant-jazz, thrash metal, música eletroacústica e por aí vai. Então vem o longo processo de agrupamento desses fragmentos em blocos de construção para uma peça. Sobre como eles encaixam juntos, e como as partes constituintes são tratadas, repetidas, alteradas em altura, invertidas, é muito intuitivo. Por exemplo, a seção do meio de Fragmenta figura uma amostra de quarteto de cordas, progressivamente sobreposta em camadas, que permaneceu musicalmente não resolvida por algum tempo. Isso só foi resolvido quando eu eventualmente usei uma amostra de thrash metal que funcionou tão bem que mudou radicalmente meu olhar sobre a peça, então eu a retrabalhei completamente. Reconhecer esse momento é crucial. (WALL, sem data).

Entretanto, diferentemente do tipo teórico de DJ mencionado ${ }^{135}$, Wall não desafia nem o conceito de obra, nem o de autor-compositor-criador. Ele simplesmente prevê dois tipos de escuta: uma de trabalho, que escuta as músicas em sua possível destinação - a reciclagem musical; e uma de apreciação, que escuta as músicas escutando-as, ou seja, sem uma colocação de uma função a priori. Que ambas se misturem, que sejam polos em tensão, é natural; o musicólogo o faz, de repente só escutando estruturas e estruturações, em meio a um concerto. Entretanto, talvez o sampleamento, acelerando, facilitando e difundindo algumas práticas apropriativas, de fato aumente em média a sensibilidade cultural quanto à colocação da escuta como instrumento. Não chego a admitir (ainda?), entretanto, que não existam mais peças, mas apenas camadas sonoras e momentos prediletos. Admitir tal fragmentação da escuta como o modo de operar, e não apenas um, é deixar pra trás coisas relevantes demais; a concepção de estrutura musical, por exemplo, mas inúmeras outras.

A música, essa produção, pode se ver ou não veiculada a uma ideologia da razão instrumental, ou da eficiência comercial (que apontaria na direção da redução da música a uma mercadoria $\left.{ }^{136}\right)$. Já foram indicadas várias formas de revalorização da escuta, para longe de uma atitude de consumo passivo, rumo à de uma experimentação viva, no que concerne à colagem musical. Além disso, diversas obras operam no sentido de uma resistência à essa dominância da esfera econômica, e em vez de elegerem uma estratégia essencialmente modernista, da construção de uma alteridade radical (que

135 Trato o DJ, nessa passagem, não como um sujeito bem localizado, mas como um membro de uma classe genérica de artistas que existem por pressuposto.

136 O que seria chamado, em outras instâncias, de reificação. 
recairia numa fundamentação que separaria arte e cultura), procuram modos críticos, utilizações imprevistas e inadequações, a partir de contextos específicos. Contextos de consumo, circulação, difusão e acessibilidade musical; contextos culturais específicos.

A prática do plunderphonics, por exemplo, elege canções de sucesso para deslocar seus signos, desfamiliarizá-las, despertando outros modo de escuta e interação com uma música que se quis produto de consumo, mais do que de invenção, pensamento, reflexão e escuta ${ }^{137}$. Ou seja, o faz a partir de dados culturais mais amplos, tanto quanto a partir de dados mais especificamente musicais. Nesse sentido, Chris Cutler (2004, p. 141), teoriza: "De todos os processos e produções que emergiram do novo meio, o da gravação, a pilhagem sonora é aquele mais conscientemente autorreflexivo; ela começa e termina apenas com gravações, com o já tocado." Continuando:

Gravações enquanto objetos não fazem distinção entre 'alta' e 'baixa' cultura, 'arte' e 'pop'. A gravação torna igualmente acessíveis todas as músicas - em todos os sentidos. (...) Tempo e espaço são homogeneizados na caixa de som caseira ou no fone de ouvidos, e o CD de música pop custa o mesmo que o CD de música clássica e provavelmente advém da mesma loja. Todas as mercadorias são iguais. (idem, p. 147).

(...) Vazamento, infiltração, adoção, osmose, abstração, contágio: estes descrevem a vida de uma obra sonora hoje em dia. Eles são responsáveis por uma convergência estética geral, nas margens de gêneros dantes mutualmente excludentes - e através do golfo entre a alta e a baixa arte. Há agora toda uma gama de obras sonoras nas quais não faz simplesmente sentido falar em termos de alto ou baixo, artístico ou popular, de fato onde os dois se interpenetram tão profundamente que qualquer tentativa de discriminar os dois é uma de entender a revolução sonora que tem sido efetuado através do meio da gravação sonora.

A 'pilhagem sonora' dirige-se justamente a esse domínio da gravação. Ela trata do ponto em que tanto o domínio público e o mundo sonoro contemporâneo encontram os aspectos transformadores e organizacionais da tecnologia de gravação; onde escutar, produzir, criticar e criar se elidem." (ibidem, p. 152).

Faço agora exemplificações de abordagens à questão colocada do antagonismo entre cultura e arte, antagonismo esse que já reflete uma identificação da cultura com o mercado, com a cultura de massas, e dos produtos culturais (como o termo já indicia) com as mercadorias.

Com isso não se quer aqui uma visão simplista; as exemplificações têm por

137 Essa música só é reduzida a mercadoria por aqueles que a quiseram reduzi-la. Trata-se de uma questão de intenção e discurso. É possível colocar a prática do plunderphonics contra essa intenção e discurso. 
objetivos mostrar ênfases nesse polo da valorização ou não de um antagonismo entre alta e baixa cultura, ou entre cultura e arte. É impossível, entretanto, separar por completo as coisas: a influência das formas musicais das danças populares e de salão nos compositores eruditos de todos os períodos dá mostras disso. É também impossível, ao menos em relação ao período moderno, não fazer alguma separação entre elas. Não obstante, o argumento indica que, com a cultura de massas, essa separação passa a ser alvo de debates: o modernismo tardio procura, ao menos em discurso, extirpar-se da influência da baixa cultura; esse repúdio, entretanto, não seria algo característico do período pós-moderno subsequente, e existiriam inúmeras tentativas de embaralhar essas categorias e separação.

Começo com uma obra e um movimento de outra que exibem uma afinidade tipicamente moderna, segundo a linha de argumentação tomada. O terceiro movimento da Sinfonia, de Luciano Berio, III. In ruhig fliessender Bewegung ${ }^{138}$, bem como Photoptosis: Prélude for Large Orchestra, de Bernd Allois Zimmermann (ambas de 1968). Como já comentado, Berio elege o terceiro movimento da Sinfonia No. 2 (1895) de Gustav Mahler como base musical, ao qual vai adicionando/sobrepondo citações diversas de músicas de compositores renomados, tais quais a 4 a Sinfonia de Mahler, o Concerto para Violino de Alban Berg, o Converto para Violino de Johannes Brahms, Der Rosenkavalier de Richard Strauss, Fünf Orchesterstücke de Arnold Schoenberg, Gruppen de Karlheinz Stockhausen, Kantate de Anton Webern, La Mer de Claude Debussy, La Valse de Maurice Ravel etc. (HICKS, 1981-2). A eleição da obra de Mahler como música predominante a coloca como elemento chave para a apreensão das citações diversas; coloca também o compositor como o elo possível dentro dessa genealogia da música de concerto europeia, que desembocaria na própria obra de Luciano Berio. Berio, por sua vez, ao absorver toda essa tradição, seria um de seus herdeiros. Se a música de Mahler é cheia de alusões, Berio, como herdeiro, radicaliza esse traço percebido no seu compositor-herói-românticomoderno, e então trabalha com citações diretas, colagens musicais. As referências a um modo de atuação modernista são ainda reforçadas pela utilização de textos, a maior parte dos quais pertencente à obra O Inominável [The Unnamable] de Samuel Beckett; segundo Jameson, justamente um caso paradigmático do modernismo tardio (JAMESON, 2005, p. 230).

Na seção central de Photoptosis há a seguinte configuração sonora: um pedal, na

138 [Com um movimento quieto e fluente]. 
região médio aguda, segurado pelas cordas, estático, enquanto diversas pontuações instrumentais intervêm. Estas são notas que se acumulam em harmonias dissonantes nos metais, complementos harmônicos momentâneos realizados no registro grave, ataques percussivos, rufos bruscos e curtos de caixa clara e chimbau, crescendos em rulo num prato, ataques de tímpano (sempre a mesma nota), trinados nos instrumentos de sopro, figurações nos sopros, acordes dissonantes ao piano. Tudo conduz para o momento em que esta configuração se desfaz, há como um desanuviamento, o pedal recede; é como se o céu abrisse. As intervenções cessam, e de repente se está a ouvir o trecho inicial do quarto movimento Presto, da Nona Sinfonia de Ludwig Beethoven. Retrospectivamente, a partir dessa revelação, parece que antes se estava no escuro do sonoro, e os contornos de algumas das intervenções eram, na verdade, trechos da obra de Beethoven, mas tal qual o olhar sob uma luz tênue e difusa, só era possível imaginar o objeto visado. Ademais, o objeto visado, isto é, o quarto movimento, é justamente caracterizado por articular, entre um recitativo de contrabaixos, colagens da própria sinfonia de Beethoven, em forma de rememorações. Assim, em Photoptosis, não há arbitrariedade no aparecimento da obra de Beethoven: é como se ela já estivesse lá. Extrapolando, é como se Beethoven fosse uma figuração necessária na trajetória de um músico, e que a partir dele tecem-se memórias de outros importantes momentos na história.

É interessante notar que, da mesma forma, o próprio pedal que antecipa a entrada das colagens é antecipado na primeira seção da peça, aparecendo metaforicamente como uma ressonância. Da ressonância ao soar é uma questão de excitação: um determinado corpo tem como características ressoar certas frequências mais que outras; se excitado de um determinado jeito, seu destino é soar em acordo com suas ressonâncias, o que de certa forma é também um desvelar; sendo um desvelar, indica que o que se desvelou já estava implicado. Assim, pode-se pensar a imagem do destino e da alteridade atrelada a essa obra.

Em ambas as músicas é possível interpretar que seus compositores seriam herdeiros de uma tradição musical bem estabelecida (e que se consolidaria com suas obras). A volta ao passado é tanto uma homenagem quanto uma atualização do passado, frente o presente: é a figura do criador que continua a trajetória progressiva da música e que dá vida ao caminho histórico que desemboca nele.

Tal postura não poderia ser mais diferente do que a de um Bernard Parmegiani, em 
Pop'ecletic, um ano após ${ }^{139}$, com estilo humorado e leve, flertando com formas dançantes de rock e jazz. Realiza loops em fragmentos de música, transformando-os assim em bases rítmicas e texturais, nas quais são feitas diversas inserções, também de música orquestral de concerto e efeitos eletrônicos. O tipo de montagem antecipa a que aparecerá em Beyond the Valley of Death (1977), pelo grupo The Residents, no álbum The Beatles Play the Residents and the Residents Play the Beatles.

Três anos antes, em 1966, James Tenney havia composto Collage \#2 ("Viet Flakes"), obra usada como trilha para o vídeo Viet Flakes de Carolee Schneemann, exibido durante uma de suas performances ${ }^{140}$. O vídeo mostra imagens de atrocidades ocorridas devido à guerra no Vietnã; a música cola trechos de músicas pop americanas, música vietnamita, música clássica de concerto, entre outras coisas. Algumas das fontes musicais são reconhecíveis e, justapostas à imagens de pessoas feridas e moribundas, adquirem tom sarcástico: a Sinfonia No. 9 de Beethoven (e sua conotação simbólica da paz e união entre os povos), a canção We Can Work It Out [nós podemos resolver isso], dos Beatles (com frases como "a vida é curta, e não há tempo para brigas e confusões, meu amigo", e "eu sempre pensei que isso era um crime"), menções a "sweet love" [doce amor] etc. É bem possível que a sensibilidade americana à época pudesse perceber ainda mais conotações simbólicas a pairar sobre a obra. A música asiática nela contida (vietnamita, ou ainda, que passa a representar os vietnamitas), sempre aparece constrita, em volume mais baixo, sem tempo para se desenvolver, aludindo, de modo alegórico, ao conflito.

Sobre essa fase de Tenney, Larry Polansky (1983, p. 172) escreve:

Nesses seis anos [no qual residiu em Nova York, 1964-1970] seu trabalho é caracterizado por um novo interesse no que pode ser chamado de arte da performance, música eletrônica, uma exploração de princípios políticos e sociais, e um afastamento do virtuosístico e do técnico, tanto na música instrumental quanto na música eletrônica.

E prossegue, sobre a peça:

'Viet Flakes' é uma das peças mais simples de Tenney. Consiste em fragmentos de de canções populares de rock'n'roll do meio da década de

139 Há certa confusão quanto ao ano da obra, entre as fontes, mas no catálogo do compositor aparece como de 1969, como "suite du film Je, tu, elles" de P. Foldés. Disponível em: <http://www.parmegiani.fr /index2.html>. Acesso em: 15 jul. 2012.

140 Snows (1967), Segundo sítio oficial. Disponível em: <http://www.caroleeschneemann.com/works.html>. Acesso em: 15 jul. 2012. 
60 ('We Can Work it Out', 'Sunny', '96 Tears' etc.), música asiática (provavelmente vietnamita) e música clássica ocidental, todas mais ou menos ajuntadas aleatoriamente. Os fragmentos têm durações de um a cinco segundos, e não parece haver nenhuma estrutura coordenando tudo isso, exceto que nenhum dos pequenos pedaços é utilizado mais do que uma vez (apesar das repetições internas das próprias canções tornarem isso difícil de determinar). (idem, p. 173-4).

Ademais, deixando a problemática da guerra de lado, como fez o texto de Polansky, é de interesse que, ainda mais do que em Pop'ecletic, há um nivelamento dos materiais, uma homogeneização dos mesmos através da escolha das transições de timbre e do ritmo da peça (das durações dos fragmentos, das colagens). Disso também infere-se uma postura que não separa em categorias distintas a música de concerto e a música pop, e que trata da cultura, sem essas discriminações preventivas, de um modo amplo e geral (através de referências e imagens sonoras).

Ainda sob outra perspectiva, equacionando alta e baixa cultura através de um critério de eficiência (não apenas comercial mas em termos de acesso e massificação), John Oswald (2000, p. 14) fala de sua obra Plexure (1993):

Plexure é (...) uma visão panorâmica. Você não consegue ver as árvores a essa resolução, ao olhar para a floresta. Os limite dessa floresta é a primeira década da era do CD, 1982-92, de uma perspectiva dominante euro-americana, que o modo como é na música pop, 'pop' sendo definido como música que é popular. Beethoven é música pop e o período cool do Miles Davis é música pop, e ambos são música pop nos anos 80 , e ambos Elvis e The Doors vendiam milhões em 1992.

A Sagração da Primavera (1913) de Stravinsky também exemplifica a colocação de Oswald. Foi conhecida pela intensidade de sentimentos que provocava nos seus primeiros ouvintes; suas inovações rítmicas foram analisadas com entusiasmo, assim como sua orquestração e composição por blocos. Tornou-se uma obra canônica e pivô do modernismo, de tal modo que teria sido, sob esse ponto, mais correto que fosse mixada à Sinfonia No. 5 (1808), de Beethoven, em vez d'O Pássaro de Fogo (1910), na composição Strathoven (1985), de Luc Ferrari. Bernard Parmegiani incluiu a entrada das cordas do trecho da Dança dos Adolescentes, decerto um gancho stranvisnkiano, em Du Pop à L'âne (1968) $)^{141}$, ao lado de trechos de uma obra para piano de Prokofiev e outra para orquestra de Bartók, depois de uma seção com uma base de batuques em bongôs. John

$141 \mathrm{Na}$ página do compositor consta como 1968, mas com a observação: "création : Exposition des Musiques Expérimentales/GRM, Maison de Radio France, 1969". Informação disponível em: <http://www.parmegiani.fr/index2.html>. Acesso em: 15 jul. 2012. 
Oswald parece haver tentado devolver à obra seu caráter de selvageria, tranquilizado e encoberto ao longo do tempo pela progressiva familiaridade adquirida com a obra, gravada e executada inúmeras vezes, por ter-se mantido um sucesso, tanto artístico quanto comercial. Spring (1980), de Oswald, passa rapidamente, em ritmo acelerado; usando momentos densos e gestos impetuosos da Sagração, pontua obsessivamente com ataques percussivos e estabelece loops agressivos e sobreposições ruidosas.

Curiosamente, trechos da Sagração são mixados com ruídos eletrônicos caricatos na introdução de uma versão do videoclipe da música Intergalactic, do grupo de rap Beastie Boys. O vídeo, lançado em 1998, apresenta, antes da música do grupo começar, uma cena em que cientistas vêm do espaço sideral rumo à Terra em um robô gigante. Stravinsky goes pop: A Sagração da Primavera, de Stravinsky, parte integrante da cultura pop hodierna. 


\section{Conclusão}

Durante esta dissertação forneci exemplos de como as práticas de colagem musical são bastantes disseminadas na música experimental; de como pode-se traçar seus antecedentes em algumas práticas realizadas na tradição da música ocidental de concerto e na área das artes visuais.

A história da colagem na música eletrônica experimental é também uma história da fonografia, uma história das relações entre a fonografia e a escolha dos materiais composicionais, das manifestações do potencial autorreflexivo da fonografia: fazer com o já feito, montar gravações com o gravado. Nessa direção, mostrei como é possível realizar uma pequena história das mídias e tecnologias em relação à colagem musical, fornecendo exemplos.

Estabeleci categorias que pudessem nortear $\mathrm{o}$ entendimento das diferentes abordagens e concepções usadas. Trabalhei com a referencialidade. Mostrei como ela pode ser um importante aspecto composicional, e como essa noção tece variadas relações com as músicas que usam procedimentos de colagem musical. Comentei dois temas de interesse. Como expresso na introdução, forneci exemplos sempre que possível.

Chris Cutler (2004, p. 154-5), em Plunderphonia, faz uma breve revisão das aplicações do sampleamento, separando-as em cinco tipos.

Ali Está: as gravações são tratadas como objetos-encontrados, os quais resultam em sons, ou ainda como sons-encontrados ou objetos sonoros-achados. Não são tomadas como artefatos culturais individualizados, mas como aquilo que estava lá e fezse ouvir. Não são tomadas propriamente como material composicional, mas como conteúdo sonoro de um evento musical predefinido. Inclui peças envolvendo uso de rádio; inclui peças que usam uma estrutura estabelecida a priori, sem relação aos conteúdos específicos das gravações utilizadas.

Importações Parciais: partes importantes advêm de gravações, sendo o resto produzido especificamente para o trabalho em questão. Relaciona-se com a categoria do arranjo, embora não implique necessariamente o estatuto de arranjo ou remix ao trabalho. Ao fato de usar sampleamento não é dado especial ênfase, mas sim para a nova 
disposição musical dos elementos. É um tipo intermediário. O sampleamento é um dos procedimentos utilizados, não necessariamente o mais importante.

Importação Total: o trabalho criativo tem como assunto, tema e objeto gravações de outrem. A pilhagem sonora [plunderphonics] enquadra-se aqui. As criações podem frequentemente ser consideradas interpretações e reescutas compartilhadas das gravações que utilizam. Há um flerte com o plágio, mas apenas superficialmente: não há intenção nenhuma de enganar outros quanto à autoria dos trabalhos. É uma aplicação autorreflexiva, pois acaba por se referir ao próprio processo de apropriação de material alheio. Assim, promove reflexões específicas sobre autoria e também sobre os processos fonográficos envolvidos.

Fontes Irrelevantes: o reconhecimento das fontes das gravações não é considerado relevante. O material é usado como se não possuísse constituição histórica, isto é, como puro som, ou ainda, menos ingenuamente, como som musical não referencial. Há uso instrumental do sampleamento, desreferencializador.

Fontes Não-Identificáveis: os sons amostrados são tratados de forma a ser impossível indicar suas fontes. Há a exploração de novas possibilidades sonoras, conseguidas através da modificação radical dos sons, ou ainda uma postura que remeteria ao esgotamento da possibilidade de produzir novos sons - só se pode recombiná-los, rearranjá-los.

Embora não tenha seguido essa tipologia de aplicação, abordei todos esses usos: diferentes maneiras de realizar colagens musicais, diferentes concepções de música e das relações com o material musical.

É tentador afirmar que há cada vez mais músicas e práticas musicais que utilizam colagens musicais dentro da música experimental. De qualquer modo, não posso fazê-lo. A impressão de que isso ocorre, entretanto, pode ser traçada. Primeiro, por um aumento do número de ferramentas que permitem e reforçam a ideia da colagem musical (hoje em dia há inúmeros softwares ${ }^{142}$, mais aplicativos, além da manutenção de tecnologias mais antigas como o instrumento sampler e outros hardwares, equipamentos, o toca-discos, o toca fitas cassete etc.) Segundo, há uma guinada estética na música de sucesso comercial (doravante chamada música pop) em direção à intensificação, não apenas das práticas de remix e do sampling, como também de uma sensibilidade própria ao pastiche.

142Exemplos abundam: Supercollider, Pure Data, Max, Audiomulch, Ableton Live etc. 
Embora a música pop possa ser vista como desde sempre ligada ao pastiche, ela agora o tem como prática padrão; as tendências ditas retrôs evidenciariam essa guinada ${ }^{143}$. Terceiro, a valorização do conceito de sustentabilidade, que carrega consigo a valorização da prática da reciclagem. A colagem musical pode ser considerada análoga a uma reciclagem musical. Quarto, há nos espaços urbanos tantos sons, tantos detritos sonoros produzidos por tecnologias - carros, aviões, helicópteros, máquinas diversas, mas especialmente caixas de som, espalhadas por todos os lados (apresentadas como dispositivo autônomo ou integrando televisões, rádios etc.) Ao contrário de ver essa situação como apenas uma condição de saturação urbana e poluição sonora, é possível entende-la relacionando-a a um modo específico de criar um tipo de presença na sociedade contemporânea:

Em um universo de caixas de sons e barulhos urbanos, eu não posso simplesmente supor que uma criança aprenda apenas através de meios áudio-mecânicos a reconhecer a presença humana (...). Caixas de som, hoje em dia, são majoritariamente usados para projetar ainda outra evidência de presença humana dentro de todos os aspectos de nossas vidas. A perene presença de música ambiente, conversas e notícias cria uma comunidade ideal ao redor de nós, uma comunidade que acreditamos estar 'viva'. (EMMERSON, 2000, p. 210).

Dessa forma, como é natural que se interaja com nossa comunidade e ambiente, que se utilize esses elementos para construir e manter viva uma cultura, pode-se indicar que, nesses ambientes urbanos, a música, tocada através de caixas de som, é mais um dos elementos a serem apropriados e manipulados. Um dos elementos mais presentes e pregnantes.

Jean-François Lyotard, em O Inumano, escreve sobre como o olho constantemente busca reconhecer o objeto visado. De fato, não há reconhecimento perceptivo que satisfaça a exigência de uma descrição completa do objeto, pois cada visada reconhece que o campo de apresentação do objeto é diferente a cada vez, e que há sempre mais para ver, além da identificação do objeto. Além do isto é isto, há o ver. Segundo o autor, a escrita também se encontraria sob algo similar a essa fé no inesgotável sensivel:

143Retrô seria uma referência ao que é retrógrado. No retrô, o próprio resgate de algo retrógrado é apresentado como novidade; o resgate é positivo. Para um relato de como a música pop está voltandose cada vez mais à tendência retrô e nostálgica. (REYNOLDS, 2011). 
(...) a escrita é mergulhada no campo das frases, por onde avança à custa de tentativas, de ensaios, ao encontro do que quer dizer e não ignorando nunca, quando para, que o que fez foi suspender por um instante (que pode ser toda uma vida) a sua exploração e que, para além desta escrita parada, estão uma infinidade de palavras, de frases e de sentidos latentes, sofredores talvez, e tantas coisas para dizer como no princípio. (LYOTARD, 1997, p. 25).

Gostaria de perguntar se será possível expandir essa constatação quanto ao fazer musical. Que o fazer musical esteja mergulhado no campo da música, ao encontro de uma musicalidade, não ignorando a incompletude de sua busca, quando finalmente para. E quando o fazer musical para, senão quando desiste ou quando cria novas obras e quando apresenta novas performances? Será que as obras e gravações de performances, paradas, esperam um fazer musical que busque atualizá-las, para colocálas em jogo de novo? Será que elas mesmas não indicam, para fora de s, que há uma infinidade de sentidos latentes nelas? Suspeito que as práticas de colagem musical respondam à incompletude inerente a cada música. À incompletude da obra e da performance em meio ao musical. 
Referências $^{144}$

ADORNO, T. W. Teoria Estética. Lisboa: Edições 70, 2008.

Introdução à Sociologia da Música: Doze Preleções Teóricas. São Paulo:

Editora Unesp, 2011.

ALLEN, W. Manhattan. 1979. Filme ficcional. Estados Unidos: Jack Rollins \& Charles H. Joffe Productions.

ANDERSEN, P. W. S. Resident Evil. 2002. Filme ficcional. Estados Unidos, Reino Unido, Canadá, Alemanha: Constantin Film, New Legacy Films, Davis Films, Impact Pictures.

ANNO, H. Neon Genesis Evangelion. 1995-6. Série de animação para TV, 26 episódios. Japão: Gainax, Tatsunoko.

ARGAN, G. C. Arte Moderna: do iluminismo aos movimentos contemporâneos. São Paulo: Companhia das Letras, 1992.

BAILEY, T. B. W. Microbionic: Radical Electronic Music and Sound Art in the 21st Century. Creation Books, 2009. Progressive Lycanthropy. Mirror Tapes, MT002, 2010. Cassete sonoro. 1 livro, $23 p$.

Unnoficial Release: Self-Released and Handmade Audio in Post-Industrial Society. Lexington: Belsona Books, 2012.

BARISON, D.; ROSS, D. The Ister. 2004. Filme documentário. Austrália: Black Box Sound and Image. 
BARRIĖRRE, F. Reflections on the state of electroacoustic music today: aesthetic evolution and relation with the public.. In: Bennett, G.; Clozier, C.; Hanson, S.; Roads, C.; Vaggione, H. (Ed.). Académie Bourges Volume I-1995: Aesthetics and Electroacoustic Music. Bourges: Acteon - Mnemosyne, 1996. p. 14-19.

BEAUDOIN, R. Counterpoint and quotation in Ussachevsky's Wireless Fantasy. Organised Sound. Cambridge, v. 12, n. 2, p. 143-151, 2007.

BENJAMIN, W. Origem do Drama Trágico Alemão. Belo Horizonte: Autêntica Editora, 2011.

BEYST, S. John Cage's Europeras: a Light and Soundscape as Musical Manifesto. 2005. Disponível em: <http://d-sites.net/english/cage.htm>. Acesso em: 28 mai. 2012.

BIANCHI, S. I.; BARRETT, R.; OBERMAYER, P. FURT Interview with Blow Up magazine An interview with Stefano Isidoro Bianchi. Blow Up Magazine. Camucia, v. 85, 2005. Disponível em: <http://furtlogic.com/node/16>. Acesso em: 15 fev. 2011.

BLACKBURN, P. Meet the Tape-beatles? Interview Philip Blackburn for Artpaper. Artpaper. Minneapolis, v. 12, n. 1, 1992. Disponível em:

<http://pwp.detritus.net/news/interviews/blackburn-artpaper.html>. Acesso em: 01 jun. 2012.

BOULEZ, P. Apontamentos de Aprendiz. São Paulo: Perspectiva, 2005.

BÜNGER, E. Let Them Sing It For You. 2003. Instalação sonora para Internet. The Third Man. 2010. Filme ficcional. Alemanha: Impakt Foundation.

BÜRGER, P. Teoria da Vanguarda. São Paulo: Cosac Naify, 2008.

BURROUGHS, W. The Ticket that Exploded. Paris, Olympia Press, 1962. 
BUSONI, F. The Essence of Music: And Other. New York: Dover Publications, 1987.

CAGE, J.. Silence. Cambridge: The MIT Press, 1970.

CARLSON, E. Beethoven's Eroica: opening chords. 2012. Vídeo. Disponível em: <http://www.youtube.com/watch?v=xb24c77zJ64>. Acesso em: 15 jun. 2012.

CARON, J.-P. Momentum I (Para Giacinto Scelsi II). 2008-2011. Obra musical.

Disponível em: <http://soundcloud.com/j-p-caron/momentum-i-for-giacinto-scelsi>. Acesso em: 15 jul. 2012.

CARROLLI, L. Through the Looking Glass. London: Penguin Books, 1994.

CAUDRON, A. John Cage List of Works (Music). 2009. Disponível em:

<http://www.johncage.info/index2.html>. Acesso em: 28 mai. 2012.

CHADABE, J. Electric Sound: The Past and Promise of Electronic Music. New Jersey: Prentice-Hall, 1997.

CHIPP, H. B. Teorias da Arte Moderna. São Paulo: Martins Fontes, 1998.

COLLINS, N. Broken Light, for string quartet and modified CD player. 1992. 1

Partitura e instruções. Quarteto de cordas e aparelho toca-CDs modificado. Disponível em: <http://www.nicolascollins.com/texts/brokenlightscore.pdf>. Acesso em: 30 mai. 2012.

Introduction to Groove, Pit, and Wave: Recording, Transmission and Music.

Leonardo Music Journal. San Francisco, v. 13, p.1-3, 2003.

. Some Notes On The History Of Devil's Music. 2009. Disponível em:

<http://www.nicolascollins.com/texts/devilsmusichistory.pdf>. Acesso em: 01 jun. 2012.

CUTLER, C. File Under popular: Theoretical and Critical Writings on Music. New York: Autonomedia, 1993. 
. Plunderphonia. In: COX, C.; WARNER, D. (Ed.). Audio Culture: Readings in

Modern Music. Nova York: Continuum, 2004. p. 138-156.

DANTO, A. Após o Fim da Arte. São Paulo: Odisseus / Edusp, 2006.

DAVIES, H. A history of sampling. Cambridge: Cambridge University Press. Organised Sound. Cambridge, v. 1, n. 1, p. 3-11, 1996.

DE CERTEAU, M. A Invenção do Cotidiano: 1. Artes de Fazer. Petrópolis: Vozes, 1980.

DELL'ANTONIO, A. Introduction: Beyond Structural Listening? Postmodern Modes of Hearing. In: . (Ed.). Beyond Structural Listening? Postmodern Modes of Hearing. Berkley: University of California Press, 2004. cap. 1, p. 1-12.

DEL NUNZIO, M. Transcrição como técnica composicional nas obras de Michael Finnissy. Relatório final de Iniciação Científica, Instituto de Artes, UNICAMP, Campinas, 2006.

DEL NUNZIO, M.; SILVEIRA, H. I. J. Dance Music. Clinical Archives, ca153, 2008. Álbum musical virtual. Disponível em: <http://clinicalarchives.blogspot.com.br/2008/07/ca153henrique-iwao-mrio-del-nunzio.html>. Acesso: 30 mar. 2011.

DEL NUNZIO, M.; SILVEIRA, H. I. J.; BARROS, B. Música Eletrônica 2004. Clinical Archives, ca294, 2009. Álbum musical virtual. Dispónível em:

<http://clinicalarchives.blogspot.com/2009/08/ca294-bernardo-barros-henrique-iwao.html>. Acesso: 30 mar. 2011.

DE MELLO, T. Sem Título. 2009. Instalação sonora.

DEMERS, J. Steal This Music: How Intellectual Property Affects Musical Creativity. Athens: University of Georgia Press, 2006. 
Listening Through the Noise - The Aesthetics of Experimental Electronic

Music. New York, Oxford University Press, 2010.

DICK, P. K. O Caçador de Androides. Rio de Janeiro: Francisco Alves, 1989.

DUGUID, B.; OSWALD, J. ESTWeb Interviews: John Oswald. 1994. Disponível em:

<http://media.hyperreal.org/zines/est/intervs/oswald.html>. Acesso em: 31 mai. 2012.

DUO N-1. Duo N-1 [enemenosvídeo]. São Paulo: Ibrasotope, Lim03, 2012. Álbum musical virtual. Disponível em: <http://www.limiares.com.br/duo-n1.html>.Acesso: 05 mai. 2011.

EARS: ElectroAcoustic Resource Site - Phonography. Sem data. Disponível em: <http://www.ears.dmu.ac.uk/spip.php?rubrique145>. Aceso em: 29 mai. 2012.

EIMERT, H. What is Electronic Music? Die Reihe. Bryn Mawr, v. 1, p. 1-10, 1958.

EMMERSON, S. 'Losing Touch?': the human performer and electronics. In: $(\mathrm{Ed})$.

Music, Electronic Media and Culture. Aldershot: Ashgate, 2000. p. 194-216.

FABRINI, R. N. O Fim das Vanguardas. In: SEMINÁRIO VANGUARDA E MODERNIDADE NAS ARTES BRASILEIRAS, 2005, Campinas. Anais eletrônicos... Campinas: UNICAMP, 2005. Disponível em:

<http://www.iar.unicamp.br/dap/vanguarda/artigos_pdf/ricardo_fabrini.pdf>. Acesso em: 23 jan. 2012.

FENERICH, A. S. Três trabalhos sobre suporte: três aparições da Primeira Sinfonia de Mahler. In: SEMINÁRIO MÚSICA CIÊNCIA TECNOLOGIA, 4, 2012, São Paulo. Anais... São Paulo: USP, 2012, p. 325-329.

FERGUSON, R. The Variety of Din. In: (Ed). Christian Marclay. Los Angeles:

Steidl/UCLA Hammer Museum, 2003. p. 18-57.

FEYERABEND, P. Adeus à Razão. São Paulo: Editora Unesp, 2009. 
FIRM, T. Mystery Tapes Etc. Sem data. Disponível em:

<http://www.plunderphonics.com/xhtml/xlaboratory.html>. Acesso em: 31 mai. 2012.

FISK, C. Returning Cycles: Contexts for the Interpretation of Schubert's Impromptus and Last Sonatas. Berkeley: University of California Press, 2001.

FROW, J. Genre. Abingdon: Routledge, 2006.

GALLIARI, A. Ouvrez les guillemets. 1995. Disponível em:

<http://mediatheque.ircam.fr/articles/textes /Galliari95d>. Acesso em: 15 mai. 2012.

GAYLOR, B. RIP: A Remix Manifesto. 2009. Filme documentário. Canadá: EyeSteelFilm, National Film Board.

GAYOU, É. The GRM, Landmarks on a historic route. Organised Sound. Cambridge, v. 12, n.3, p. 203-211, 2007.

GIBSON, W. Burning Chrome. London: Voyager, 1995.

GILLIS, G. Girl Talk - All Day Samples List. Sem data. Disponível em: <http://illegalart.net/allday/samples.html>. Acesso em: 01 jun. 2012.

GJERDINGEN, R; PERROTT, D. Scanning the Dial: The Rapid Recognition of Music Genres. Journal of New Music Research. London, v. 37, n. 2, p. 93-100, 2008.

GOLDING, J. Cubismo. In: STANGOS, N. (Ed.). Conceitos da Arte Moderna. Rio de Janeiro: Jorge Zahar Editor, 1991. p. 38-57.

GOODMAN, N. Ways of Worldmaking. Indianapolis: Hackett, 1985.

GOTTSTEIN, B. Interview mit Christian Marclay. 2008. Disponível em: <http://www.geraeuschen.de/9.html>. Acesso em: 13 mai. 2012. 
GOUDAROLIS, D. Johann Sebastian Bach: 6 Suites a Violoncello Solo. Tratore, DG001, 2011. 2 CDs. Digital estéreo.

GREENBERG, C. Arte e Cultura: Ensaios Críticos. São Paulo: Editora Ática, 1996.

HEIDEGGER, M. A questão da técnica. Scientiae Studia. São Paulo, v. 5 (3), p. 375-98, 2007.

HICKS, M. Text, Music, and Meaning in the Third Movement of Luciano Berio's Sinfonia. Perspectives of New Music. Seattle, v. 20, n. 1/2, p. 199- 224, 1981-1982.

HOLM-HUDSON, K. Quotation and Context: Sampling and John Oswald's

Plunderphonics. Leonardo Music Journal. San Francisco, v. 7, p. 17-25, 1997.

HUYSSEN, A. Mapeando o Pós Moderno. In: HOLLANDA, H. B. (Ed.). Pós-Modernismo e Política. Rio de Janeiro: Rocco, 1991. p. 15-80.

IAZZETTA, F. Além da vanguarda musical. In: GUINSBURG, J.; BARBOSA, A. M. (Ed.). O Pós Modernismo. São Paulo: Perspectiva, 2005. p. 227-246.

. Música e Mediação Tecnológica. São Paulo: Perspectiva, Fapesp, 2009.

JAMESON, F. Reification and Utopia in Mass Culture. Social Text. New York, v. 1, p. 130148, 1979.

Postmodernism, Or the Cultural Logic of Late Capitalism. Durham: Duke University Press, 1997. . "Fim da arte" ou "fim da história". In: A cultura do dinheiro: ensaios sobre a globalização. Petrópolis: Vozes, 2001. p. 73-9.

Modernidade Singular: Ensaio Sobre a Ontologia do Presente. Rio de Janeiro: Civilização Brasileira, 2005. 
JECK, P.; SARGENT, L. Vinyl Requiem. 1993. Vídeo. Inglaterra: Shinkansen. Disponível em: <https://vimeo.com/17439345>. Acesso em: 10 mai. 2012.

JONES, A. Plunderphonics, Pataphysics \& Pop Mechanics: an Introduction to Musique Actuelle. Wembley: SAF Publishing, 1995.

JORDAN, K.; MILLER, P. D. Freeze Frame: Audio, Aesthetics, Sampling, and Contemporary Multimedia. In: MILLER, P. D. (Ed.). Sound Unbound: Sampling Digital Music and Culture. Cambridge: The MIT Press, 2008. p. 97-108.

KAHN, D. Christian Marclay's Early Years: An Interview. Leonardo Music Journal. San Francisco, v. 13, p. 17-21, 2003.

KELLY, B. Sample Saturation: The Tape-beatles rip-off all of their material. Montreal Mirror, 15 ago. 1991. Disponível em: <http://pwp.detritus.net/news/interviews/kellymontrealmirror.html>. Acesso em: 15 jul. 2012.

KELLY, C. Cracked Media: The Sound of Malfunction. Cambridge: The MIT Press, 2009.

KERKHOF, I. Beyond Ultra Violence: Uneasy Listening by MERZBOW. 1998. Filme documentário. Holanda: Allegri Film.

KING, J. J.; THE LEAGUE OF NOBLE PEERS. Steal This Film 2. 2007. Filme documentário. Disponível em: <http://www.stealthisfilm.com/Part2/>. Acesso em: 28 mai. 2012.

KOHL, J. Serial Composition, Serial Form, and Procces in Karlheinz Stockhausen's Telemuisik. In: LICATA, T. (Ed.). Electroacustic Music: Analytical Perspectives. Westport: Greenwood Press, 2002. p. 91-118.

KÖNIG, S. sCrAmBIEd?HaCkZ!. 2006. Vídeo. Disponível em: <http://www.youtube.com/watch?v=eRlhKaxcKpA>. Acesso em: 01 jul. 2012. 
. sCrAmBIEd?HaCkZ!. Sem data. Disponível em:

<http://www.popmodernism.org/scrambledhackz/>. Acesso em: 13 mai. 2012.

KNOWLES, A. Event Scores. Sem data. Disponível em:

<http://www.aknowles.com/eventscore.html>. Acesso em: 07 mai. 2012.

KREIDLER, J. Product Placements. 2008. Vídeo. Disponível em: <http://kreidlernet.de/productplacements-e.html>. Acesso em: 30 mar. 2011.

Compression Sound Art. 2009. Vídeo. Disponível em: <http://kreidlernet.de/compression.html>. Acesso em: 15 jul. 2012.

. Music with Music. In: INTERNATIONALE FERIENKURSE FÜR NEUE MUSIK, 2010, Darmstadt. Darmstadt, Internationales Musikinstitut Darmstadt. Palestra. Disponível em: <http://youtu.be/BsFtHsxvoWs>. Acesso em: 02 mai. 2012.

LANDY, L. Understanding the Art of Sound Organization. Cambridge: The MIT Press, 2007.

LANSKY, P. My Radiohead Adventure. 2000. Disponível em: <http://www.music.princeton.edu/paul/radiohead.ml.html>. Acesso em: 15 jun. 2012.

LEBRUN, G. O Avesso da Dialética: Hegel à luz de Nietzsche. São Paulo: Companhia das Letras, 1988.

LEHMANN, H. Avant-garde Today: a Theorical Model of Aesthetic Modernity. In:

MAHNKOPF, C.-S. (Ed.). Critical Composition Today. Hofheim: Wolk Verlag, 2006. p. 942

Digitization and Concept: A Thought Experiment Concerning New Music. Search Journal of New Music and Culture. v. 7, 2010. Disponível em: <http://www.searchnewmusic.org/lehmann.pdf>. Acesso em: 01 out. 2011. 
LYOTARD, J.-F. The Postmodern Explained: Correspondence, 1982-1985. Sydney:

Power Publications, 1992.

. O Inumano. Lisboa: Editorial Estampa, 1997.

MARCONI, R. Tuning in. 1981. Filme documentário. Inglaterra: Barrie Gavin, BBC.

MASEN, M; WALTER, W. Weasel Walter Interview (22nd of January 2008, FLUC, Vienna/Austria): God of Chaos. 2008. Disponível em:

<http://www.rokkosadventures.at/Stories/weaselinterview.html>. Acesso em: 30 mai. 2012.

MCLEOD, K.; DICOLA, P. Creative License: The Law and Culture of Digital Sampling.

Durham: Duke University Press, 2011.

MILLER, P. D. Rythm Science. Cambridge: The MIT Press, 2004.

MYATT, T. New aesthetics and practice in experimental electronic music. Organised

Sound. Cambridge, v. 13 (1): p. 1-3, 2008. Editorial.

NEGATIVLAND. Fair Use: The Story of the Letter U and the Numeral 2. San Francisco: Seeland, 1995.

ABOUT "OVER THE EDGE". Sem data. Disponível em:

<http://www.negativland.com/ote/>. Acesso em: 09 mai. 2012.

NORMAN, K. Sounding Art: Eight Literary Excursions Through Electronic Music. Aldershot: Ashgate Publishing, 2004.

NYMAN, M. Experimental Music: Cage and Beyond. New York: Schirmer Books, 1992.

OLIVEIRA, W. C.; Willy Corrêa de Oliveira - O Presente. Água Forte, 2006. 2 CDs. 
OSTERTAG, B.; FRITH, F.; MINTON, P. Voice of America. 1982. Álbum musical. Disponível em: <http://bobostertag.com/music-recordings-voiceofamerica.htm>. Acesso em: 30 mai. 2012.

OSTERTAG, B. Creative Life: Music, Politics, People, and Machines. Chicago: University of Illinois Press, 2009.

OSWALD, J. Plunderphonics, or Audio Piracy as a Compositional Prerogative. 1985. Disponível em: <http://www.plunderphonics.com/xhtml/xplunder.html>. Acesso em: 15 jun. 2012.

. Plunderstanding Ecophonomics: Strategies for the Transformation of Existing Music - An Interview by Norm Igma with John Oswald. In: ZORN, J. (Ed.). Arcana: Musicians on Music. New York: Granary Books, 2000. p. 9-17.

. Bettered by the Borrower: the Ethics of Musical Debt. In: COX, C.; WARNER, D. (Ed.). Audio Culture: Readings in Modern Music. Nova York: Continuum, 2004. p. 131137.

OSWALD, J.; IGMA, N. Plunderphonics 69/96: encarte. El Cerrito: Seeland 515, 2001. 2CDs.

PALOMBINI, C. Pierre Schaeffer, 1953: Por uma Música Experimental. Revista Eletrônica de Musicologia. Curitiba, v. 3, 1998. Disponível em: <http://www.rem.ufpr.br/_REM/REMv3.1/vol3/Schaeffer.html >. Acesso em: 11 jul. 2011.

A Música Concreta Revisitada. Revista Eletrônica de Musicologia. Curitiba, v. 4, 1999. Disponível em: <http://www.rem.ufpr.br/REMv4/vol4/art-palombini.htm>. Acesso em: 14 set. 2009.

PAN\&TONE. Peter Francis Tribute. In: Bent Out of Shape. Cedar Rapids: Free music Friday, 13 mar. 2009, 2009. Faixa 7. Disponível em: <http://www.getlofi.com/?p=1607>. Acesso em: 15 jul. 2012. 
PHONOSTATIC 10. 1989. 1 cassete sonoro. Disponível em:

<http://psrf.detritus.net/volume/6/k10.html>. Acesso em 15 de julho de 2012.

POLANSKY, L. The Early Works of James Tenney. Soundings. v. 13, p. 119-297, 1983.

Disponível em:

$<$ http://eamusic.dartmouth.edu/ larry/published_articles/tenney_monograph_soundings/in dex.html>. Acesso em: 15 jul. 2012.

POZO, C. M. EXPANDED NOISEHANDS: The noise music of Merzbow. Sem data.

Disponível em: <http://noiseweb.com/merzbow/all.html>. Acesso em: 01 jul. 2012.

READ, H. Uma História da Pintura Moderna. São Paulo: Martins Fontes, 2001.

REYNOLDS, S. Retromania: Pop Culture's Addiction to Its Own Past. Nova York: Faber and Faber, 2011.

RIDDELL, A. Data Culture Generation: After Content, Process as Aesthetic. Leonardo Music Journal. San Francisco, v. 34 (4), p. 337-343, 2001.

RISSET, J.-C. Foreword. In: LICATA, T. (Ed). Electroacustic Music: Analytical Perspectives. Westport: Greenwood Press, 2002. p. xiii-xx.

ROADS, C. Microsound. Massachusetts: The MIT Press, 2004.

RUSSOLO, L. The Art of Noises: Futurist Manifesto. In: COX, C.; WARNER, D. (Ed.). Audio Culture: Readings in Modern Music. Nova York: Continuum, 2004. p. 10-14.

SCHAEFFER, P. Ensaio Sobre o Rádio e o Cinema: Estética e Técnica das Artes-relé, 1941-1942. Belo Horizonte: Editora UFMG, 2010.

Solfejo do Objeto Sonoro. Tradução para o português e narração de Conrado Silva. Sem data. Arquivo de áudio. Disponível em: <http://archive.org/details/SolfejoDoObjetoSonoro>. Acesso em: 15 jul. 2012. 
SCHWARTZ, D. Concatenative Sound Synthesis: The Early Years. Journal of New Music Research. London, v. 35, n. 1, p. 3-22, 2006.

SCHERZINGER, M. The Return of the Aesthetic-Musical Formalism and its Place in Political Critique. In: DELL'ANTONIO, A. (Ed.). Beyond Structural Listening? Postmodern Modes of Hearing. Berkley: University of California Press, 2004. cap. 9. p. 252-277.

SHELLEY, M. Frankestein or the Modern Promotheus. London: Penguin Books, 1994.

SILVEIRA, H. I. J. Colagem Musical Utilizando Amostras de Pequena Duração - Três Abordagens: Velocity, O Chá e Product Placements. In: CONGRESSO DAASSOCIAÇÃO NACIONAL DE PESQUISA E PÓS-GRADUAÇÃO EM MÚSICA, 21, 2011, Uberlândia. Anais... Uberlândia: UFU, 2011. p. 1566-1571.

STEENHUISEN, P. Sonic Mosaics: Conversations with Composers. Edmonton: The University of Alberta Press, 2009.

STOCKHAUSEN, K. Stockhausen - Opus 1970. Koln: Deutsche Grammophon, 1969. 1 Disco sonoro. . et al. Stockhausen Vs. the 'Technocrats. In: COX, C.; WARNER, D. (Ed.). Audio

Culture: Readings in Modern Music. Nova York: Continuum, 2004. p. 381-385. . List of Works. Kuerten: Stockhausen Verlag, 2010. Catálogo de obras. Disponível em: <http://www.stockhausen.org/2010_work_list_en.pdf>. Acesso em: 15 jul. 2012.

STURM, B. L. Concatenative Variations of a Passage by Mahler. 2005. Disponível em: <http://www.mat.ucsb.edu/ b.sturm/music/CVM.htm>. Acesso em: 02 jul. 2012. Adaptive Concatenative Sound Synthesis and Its Application to Micromontage Compositior. Computer Music Journal. Berkeley, v. 30, n. 4, p. 46-66, 2006. 
SUBOTNIK, R. R. Deconstructive Variations - Music and reason in Western Society. Minneapolis: University of Minessota Press, 1996.

THOMPSON, D. As Crônicas Bovinas, Parte 29: A linha tênue entre o tributo e o roubo. 2003. Disponível em: <http://daniellathompson.com/Texts/Le_Boeuf/cron.pt.29.htm>. Acesso em: 01 jun. 2012.

. Doutor Tanguinho: Marcelo Tupinambá foi um dos primeiros reis da música popular brasileira. 2002. Disponível em:

<http://daniellathompson.com/Texts/Le_Boeuf/cron.tupinamba.htm>. Acesso em: 01 jun. 2012.

THOMPSON, E. Machines, Music, and the Quest for Fidelity: Marketing the Edison Phonograph in America, 1877-1925. The Musical Quarterly. Oxford, v. 79, n. 1, p. 131171, 1995.

TRYTHALL, R. Omaggio a Jerry Lee Lewis. Sem data. Disponível em: <http://www.richardtrythall.com/15.html>. Acesso em: 01 jul. 2012.

VARÉSE, E. The Liberation of Sound (1936-62). In: COX, C.; WARNER, D. (Ed.). Audio Culture: Readings in Modern Music. Nova York: Continuum, 2004. p.17-21.

WALL, J.; JACQUES, A.; JACQUES, H. Andrew and Howard Jacques of These Records in conversation with John Wall on the eve of the release of his new CD AlterStill. Sem data. Disponível em: <http://media.hyperreal.org/zines/est/intervs/wall.html>. Acesso em: 15 jul. 2012.

WATERS, S. Beyond the Acousmatic: hybrid tendencies in electroacoustic music. In: EMMERSON, S. (Ed.). Music, Electronic Media and Culture. Aldershot: Ashgate, 2000. p. 56-83.

WATKINS, G. Pyramids at the Louvre: Music, Culture, and Collage from Stravinsky to the Postmodernists. Cambridge: Belknap Press, 1994. 
WISHART, T. On Sonic Art. London: Routledge, 1996.

WITTGENSTEIN, L. O Livro Azul. Lisboa: Edições 70, 2008.

YOSHIHIDE, O.; BAXTER, E. Normal Japanese Child: Otomo Yoshihide Interviewed by Ed Baxter. Resonance. London, v. 4, n. 2, p. 8-11, 1995. 


\section{Conteúdo do DVD anexo}

No DVD anexo, além desta própria dissertação, em formato pdf, há arquivos de áudio e de vídeo, considerados aqui sob a denominação conjunta exemplos.

Os exemplos estão organizados conforme os tópicos da dissertação em que são mencionados. Alternativamente, quando não há menção no texto, os exemplos foram organizados segundo os tópicos com os quais considerei que eles possuíam maior afinidade. $O$ início dos nomes dos arquivos remete ao tópico o qual o exemplo se relaciona. Assim, "[42] 1 john wall - fragmenta", é o primeiro exemplo relacionado ao tópico 4.2.

Alguns exemplos podem ser acessados via internet, e não constam como arquivos no DVD anexo. Todos estes foram acessados em 24 de agosto de 2012.

Por fim, as obras anexas foram utilizadas com finalidade acadêmica e não podem ser copiadas nem reproduzidas sem autorização dos respectivos autores ou detentores dos direitos autorais.

\section{Tópico 1.1}

1. Claude Debussy, Goliwoog's Cakewalk, parte de Children's Corner (1906-8). Trecho em que cita o acorde de Tristão e Isolda (1859), de Richard Wagner.

2. Tema final da Sinfonia 9 (1824), de Beethoven. Tema inspirado neste de Johannes Brahms, do movimento Finale de sua Sinfonia 1 (1876). Versão em tom menor de Gustav Mahler do tema de Brahms, no início da Sinfonia 3 (1886).

3. Ludwig van Beethoven, quarto movimento da Sinfonia 9 (excerto), com regência de Günter Wand, .

4. Franz Schubert, tema do segundo movimento (Allegretto quasi Andantino) da Sonata para piano em A menor D.537, por Arturo Benedetti Michelangeli; tema do quarto movimento (Rondo. Allegretto) da Sonata para piano em A maior D.959, por Maurizio Pollini.

5. Ferrucio Busoni, Fantasia Contrappuntistica - Fuga III (1910), tocada por Wolf Harden.

6. Frère Jacques, seguido do início do terceiro movimento da Sinfonia 1 (1888), de Mahler, seguido de Jesus Walk (2004), de Kanye West.

7. Mauricio Kagel, Ludwig Van (1969), disponível em: 
http://www.ubu.com/film/kagel_ludwig.html.

\section{Tópico 1.2}

1. Christian Marclay, Pandora's Box (lançado entre 1981-9).

2. Algumas imagens do artista Mimmo Rotella:

http://www.arasgallery.com/profile.php?id=33.

\section{Tópico 1.3}

1. John Cage, Imaginary Landscape No. 4 (1951). Interpretação do Maelström

Percussion Ensemble, dirigido por Jan Williams (1995/6).

2. Karlheinz Stockhausen, Opus 1970 (excerto).

3. The Residents, Beyond the Valley of a Day in the Life (1977).

4. Cassiber, Start the Show (1988).

5. Christian Marclay, Record Without a Cover (1985).

6. The Beatles, Revolution 9 (1968).

7. Merzbow, Batztoutai with Material Gadgets (De-Composed Works 1985 86), One Eyed Metal (1993).

8. Martin Tétreault e Ropert Le Page, Callas, la Diva et le Vinyle - Le Sistème d'Alarme Callas (1997)

9. Terre Thaemlitz, Resistance for Change - 4. Transformative Nostalgia (1998).

10. Negativland, Favorite Things (2005).

\section{Tópico 1.4}

1. John Cage, Imaginary Landscape No. 1 (1939). Interpretação do Maelström Percussion Ensemble, dirigido por Jan Williams (1995/6).

2. John Cage, Imaginary Landscape No. 5 (1952). Realização por Peter Pfister usando 42 gravações de Anthony Braxton (1995/6).

3. Pierre Schaeffer, Étude Pathétique (1948).

4. Nam June Paik, Hommage à John Cage (1959).

5. James Tenney, Collage No. 1 ("Blue Suede") (1961).

6. Karlheinz Stockhausen, Telemusik (1966).

7. Nicolas Collins, Devil's Music (1985).

8. John Cage, Roaratorio, part four (to end) (1979).

9. Dickie Goodman, Flying Saucer, Part 1 (1956).

10. Negativland, It's All In Your Head FM, faixa 2 do CD (V1.0) (2005).

11. Quizéé Anssim num Quizéé Anssim Tumém, Cactus in my Brain (trecho de um 
programa radiofônico transmitido em 24 de setembro de 2001).

12. Bob Ostertag e Fred Frith, Voice of America, part 1 (1982).

13. Mystery Tape Laboratory, GX (excerpt), publicado em fita cassete em PhonoStatic 10, 1989.

14. Lt. Murnau, Avoid Useless Noise Pt. 1 \& 2 (1982).

15. Thomas Bey William Bailey, Progressive Lycanthropy - Phase 2 (Offense) (2007, excerto). Disponível em: http://www.youtube.com/watch?v=buTIgzPIcPM.

16. Milan Knížák, Broken Music, Composition No. 5 (1979).

17. Phillip Jeck e LOL Sargent, Vinyl Requiem (1993). Filmagem documental disponível em: http://vimeo.com/17439345.

18. Duo N-1, Surfing in Turntables (2012).

19. John Oswald, Dab (1989).

20. Nicolas Collins, Broken Light - I. Corelli (1992). Interpretado por The Soldier String Quartet.

21. sCrAmBIEd?HaCkZ!, vídeo de apresentação (2006). Disponível em:

http://www.youtube.com/watch?v=eRIhKaxcKpA.

22. Bob L Sturm, Concatenative Variations of a Passage by Mahler, Lix Tetrax seguido de Highway to Heaven, Starway to Hell (2005).

\section{Tópico 2.1}

1. Weasel Walter, John Coltrane (feat. Weasel Walter) - Jupiter, da série Weasel Walter Plays Over Records (2006).

2. John Oswald, Dont (1988).

Tópico 2.3

1. Danger Mouse, 99 Problems, do disco Grey Album (2004), um mashup entre The Beatles e Jay-Z.

2. Girl Talk, All Day (2010), excerto.

Tópico 2.4

1. Willy Corrêa de Oliveira, Prelúdio II (1971-5). Piano: Caio Pagano.

2. The Residents, Swastikas on Parade (1974), excerto.

3. Michael Finnissy, Verdi Transcriptions (1972-88), excertos diversos. Piano: Ian Pace.

4. John Wall, Distill (1995).

Tópico 2.5 
1. John Cage, Williams Mix (1952).

2. Furt, Volksmusik (2002).

3. Mário Del Nunzio, Improviso em Branco e Preto (Carta às Videntes) (2004).

Tópico 2.6

1. John Oswald, Pocket (1987).

Tópico 2.7

1. Jean-Pierre Caron, Momentum I (Para Giacinto Scelsi) (versão de 2011). Redução estéreo, original em 4 canais.

2. Noah Creshevsky, Jacob's Ladder (2003).

Tópico 2.8

1. Johannes Kreidler, 5 Programmings of a MIDI-Keyboard - 5. Universität der Toten Philosophen (2006). Vídeo de performance disponível em:

http://youtu.be/aHSSopntKqE.

2. John Oswald, Prelude (1990).

3. Negativland, I Still Haven't Found What I am Looking For - Special Edit Radio Mix (1991).

4. Pierre Henri, La Dixième Symphonie de Beethoven, I. Presto (1979).

5. Pierre Henri, La 10ème Remix, I. Marche Dans le Temps (1998).

Tópico 2.9

1. Darius Milhaud, Le Boeuf sur le Toit (1919), excerto. Regência de Leonard Bernstein.

2. Guilherme Rebecchi, O Rei dos Campos de Beterraba (Sonata Tan-sá) (2010). Tópico 3.1

1. Acorde de Tristão e Isolda: aparição, citação, transformação e deslocamento. Excertos do Prelúdio da Ópera Tristão e Isolda (1859), de Richard Wagner, sexto movimento da Suíte Lírica (1926), de Alban Berg, trechos iniciais de Mild und Leise (1973), de Paul Lansky, início da canção Idioteque (2000), do grupo Radiohead.

Tópico 3.2

1. Otomo Yoshihide, The Night Before the Death of the Sampling Virus (1993), pequena montagem usando o material do CD, por Henrique Iwao.

2. John Wall, Alterstill (Nothing is Sacred) (1993-4).

3. Exemplo de violoncelo 1: Helmut Lachenmann, dois excertos de Pression (para violoncelo) (1969-70). Violoncelo: Lucas Fels. 
4. Exemplo de violoncelo 2: Johann Sebastian Bach, Suíte III em C maior, Gigue (BWV 1009, 1717-23?). Violoncelo por Dimos Goudaroulis.

5. Yasunao Tone, Musica Iconologos: Jiao Liao Fruits (1993).

6. Yasunao Tone, Solo for Wounded CD, Part I. (1995).

7. John Oswald, Velocity (1993, décimo segundo movimento de Plexure), seguido de O Chá (2004) de Mário Del Nunzio, seguido da parte musical de Product Placements (2008), de Johannes Kreidler.

8. Johannes Kreidler, In Hyper Intervals (2006-8), parte 1, compassos 62 a 73.

9. Johannes Kreidler, Dekonfabulation (2007-8), nono movimento, compassos 14 a 20.

10. Christian Marclay, One Thousand Cycles (lançada entre 1981-7).

11. Johannes Kreidler, Cache Surrealism (2008), começo; final de Living in a Box (2010).

\section{Tópico 3.3}

1. Luiz Eduardo Castelões, Estudos de Plágio No. 2: Thelonious Monk Puzzle (2003).

\section{Tópico 3.4}

1. Erik Bünger, Let Them Sing For You (2003), vídeo-demonstração.

\section{Tópico 3.5}

1. Karlheinz Stockhausen, Hymnen (1966-7), região 3.

2. Henrique Iwao, Da Série "Transposição Musical, por Analogia, dos Estudos Críticos Marxistas": Fim da História/Esquizofrenia (2011). Vídeo documental de uma apresentação disponível em: http://www.youtube.com/watch?v=WV_tvHCQeZY.

3. Henrique Iwao, Primeiro Acorde (2008), excerto de uma apresentação de 2008.

4. John Oswald, Plexure: 10. Temperature (1993).

5. Richard Trythall, Omaggio a Jerry Lee Lewis (1975).

6. Henrique Iwao, Sobre a Pausa 04 (2006).

Tópico 3.6

1. Helmut Lachenmann, Ein Kinderspiel, movimento 7 - Schattentanz (1980). Piano: Marino Formenti.

\section{Tópico 3.7}

1. Erik Carlson, Beethoven's Eroica: Opening Chords (2012). Disponível em: http://youtu.be/xb24c77zJ64. 
2. Charles Dodge, Any Resemblance Is Purely Coincidental (1980).

Tópico 3.8

1. Noah Creshevsky, Red Carpet (2005).

2. Vladmir Ussachevsky, Wireless Fantasy (1960).

3. John Oswald, Pretender (1988).

Tópico 3.9

1. Henrique Iwao, Baby (2009), excerto.

2. Alexandre Fenerich, Étude D'après Mahler (2004).

Tópico 4.1

1. Henrique Iwao, Uh (2010-2), excerto.

2. Johannes Kreidler, Compression Sound Art (2009). Disponível em:

http://www.youtube.com/watch?v=7iMPxJ8WSkc.

3. Pan\&Tone, Peter Francis Tribute (2009).

4. Otomo Yoshihide, Mats Gustafsson e Mikito Ozeki, With Records (2009). Video documental disponível em: http://vimeo.com/23103828.

5. Louis Andriessen, In Memoriam (1971).

6. Rodolfo Caesar, Fuga III de Bach/Busoni/Caesar (2008). Original em 8 canais. Redução estéreo por Henrique Iwao, a fim de clarificar o processo descrito no tópico.

\section{Tópico 4.2}

1. John Wall, Fragmenta (1995).

2. Luciano Berio, Sinfonia, terceiro movimento, III. In ruhig fliessender Bewegung (1968). Regência do próprio compositor.

3. Bernd Allois Zimmermann (1968), Photoptosis: Prélude for Large Orchestra (1968). Regência de Bernhard Kontarsky.

4. Bernard Parmegiani, Pop'ecletic (1969).

5. James Tenney, Collage No. 2 ("Viet Flakes") (1966). Apresentada junto com vídeo de Carolee Schneemann, Viet Flakes (1965) (a data correta está aberta a disputa). Disponível em: http://www.youtube.com/watch?v=Il6aoxfO-pE.

6. Luc Ferrari, Strathoven (1985).

7. Três aparições da Sagração da Primavera (1913), de Igor Stravinsky. Excertos de Bernard Parmegiani, Du Pop à L'âne (1968) + John Oswald, Spring (1980) + The Beastie Boys, Intergalactic (1998). 